UNIVERSIDADE DE SÃO PAULO

FACULDADE DE FILOSOFIA, LETRAS E CIÊNCIAS HUMANAS DEPARTAMENTO DE LETRAS ORIENTAIS

PROGRAMA DE LÍNGUA, LITERATURA E CULTURA JAPONESA

MONICA JESSICA APARECIDA FERNANDES YAMAMOTO

A Abordagem Lexical no ensino sistematizado e explícito do léxico para aprendizes de língua japonesa em contexto de ensino regular e como disciplina obrigatória

Versão Corrigida 


\title{
A Abordagem Lexical no ensino sistematizado e explícito do léxico para aprendizes de língua japonesa em contexto de ensino regular e como disciplina obrigatória
}

\author{
Versão Corrigida
}

Dissertação de Mestrado apresentada ao Programa de Pós-Graduação em Língua, Literatura e Cultura Japonesa da Faculdade de Filosofia, Letras e Ciências Humanas, da Universidade de São Paulo, como parte dos requisitos para obtenção do título de Mestre em Letras.

Orientadora: Prof. ${ }^{a}$ Dra. Junko Ota

De acordo 
YAMAMOTO, M. J. A. F. A Abordagem Lexical no ensino sistematizado e explícito de vocabulário para aprendizes de língua japonesa em contexto de ensino regular e como disciplina obrigatória. Dissertação apresentada à Faculdade de Filosofia, Letras e Ciências Humanas da Universidade de São Paulo para obtenção do título de Mestre em Letras.

Aprovado em:

Banca Examinadora

Prof. Dra. Sandra R. B. G. de Paula

Julgamento:

Profa. Dra. Fernanda L.Ortale

Julgamento:

Profa. Dra. Junko Ota

Julgamento:
Instituição: Universidade Federal de São Carlos Assinatura:

Instituição: Universidade de São Paulo

Assinatura:

Instituição: Universidade de São Paulo

Assinatura: 


\section{DEDICATÓRIA}

Ao meu saudoso pai Antônio

À minha querida irmã Karina

Aos meus amados avós José e Benedita

Aos olhos da saudade, como o mundo é pequeno!

Charles Baudelaire 


\section{AGRADECIMENTOS}

A concretização desse trabalho só foi possível graças ao apoio das muitas pessoas que me acompanharam durante essa prazerosa e árdua caminhada.

Agradeço à minha família, por compreender meus momentos de ausência.

Agradeço ao meu marido Eduardo Yuji Yamamoto pelo apoio incondicional, pela compreensão das circunstâncias, pelos muitos conselhos e pelo constante incentivo.

Agradeço à minha mãe Maria, meu eterno exemplo de vida.

Agradeço à minha orientadora por sempre apoiar meus passos.

Agradeço à escola onde realizei a pesquisa, por se dispor a colaborar com o desenvolvimento da área de ensino de língua japonesa.

Agradeço aos meus alunos, tanto os que participaram diretamente da pesquisa quanto aos demais, pelo empenho e dedicação ao estudo da língua japonesa.

Agradeço aos meus amigos, em especial à Ana, à Tássia e ao Felipe, por me acompanharem de perto nesta trajetória e contribuírem de diversas formas.

Agradeço à CAPES pelo apoio financeiro.

Agradeço aos membros da banca pela atenção e pelas preciosas contribuições.

Agradeço aos funcionários do Departamento de Letras Orientais e da Seção de PósGraduação pelo constante suporte. 


\section{RESUMO}

YAMАМОТО, M. J. A. F. A Abordagem Lexical no ensino sistematizado e explícito do léxico para aprendizes de língua japonesa em contexto de ensino regular e como disciplina obrigatória. 2016. 217f. Dissertação (Mestrado) - Faculdade de Filosofia, Letras e Ciências Humanas, Universidade de São Paulo, São Paulo, 2016.

A Abordagem Lexical (LEWIS, 1993) se distingue por conferir ao léxico a posição de elemento central no processo de ensino-aprendizagem de uma língua estrangeira. É constituída por princípios que propõem reavaliar a importância do léxico e o tipo de tratamento dado a esse elemento pelos professores e aprendizes durante o processo de aprendizagem da língua-alvo. De fato, esse elemento da língua tem um alto valor, uma vez que perpassa as quatro habilidades linguísticas, configurando-se em fator determinante para a comunicação. No entanto, a complexa natureza multifacetada das palavras e a realidade fluida do léxico dificulta a aprendizagem, acarretando em defasagem da competência lexical. O objetivo desta pesquisa é verificar as contribuições do ensino sistematizado e explícito de vocabulário norteado pelos princípios da Abordagem Lexical para a aprendizagem do léxico em língua japonesa, a curto e longo prazo, tanto quantitativamente quanto qualitativamente. Buscamos averiguar se complementar a aquisição incidental com o ensino sistematizado e explícito do léxico norteado pelos princípios da Abordagem Lexical contribui para o desenvolvimento da competência lexical do aprendiz de língua japonesa. Se sim, de que forma e em que medida? Trata-se de uma pesquisa empírica, de natureza aplicada, descritiva, com abordagem quantitativa e delineamento quase-experimental. Para responder ao problema de pesquisa, realizou-se um experimento com duas turmas do sexto ano do Ensino Fundamental II de uma escola particular da região da Grande São Paulo. Um grupo de participantes compôs o grupo experimental e outro o grupo controle. Elaborou-se uma sequência didática desenvolvida nos dois grupos, com a adição de quatro intervenções pedagógicas elaboradas com base nos princípios da Abordagem Lexical apenas no grupo experimental, sendo elas: a) uma aula sobre o conceito de chunks e outra sobre os tipos de itens lexicais; b) exercícios complementares com foco lexical; c) atividades complementares com foco lexical; e d) elaboração de um caderno lexical. Logo após o término da sequência didática e trinta dias depois, os participantes de ambas os grupos responderam ao teste VKS (Vocabulary Knowledge Scale) (WESCHE; PARIBAKHT, 1993). Os dados coletados passaram por um tratamento estatístico e foram analisados descritivamente. Realizou-se também uma análise das respostas escritas, visando identificar evidências de um possível efeito das intervenções pedagógicas no desempenho dos aprendizes. Os resultados das análises indicaram que o grupo experimental teve um desempenho superior ao grupo controle. Com base nisso, concluiu-se que o ensino sistematizado e explícito norteado pelos princípios da Abordagem Lexical contribuiu para o desenvolvimento da competência lexical do aprendiz de língua japonesa no contexto de ensino comtemplado nesta pesquisa.

Palavras-chave: língua japonesa, abordagem lexical, ensino-aprendizagem de vocabulário, ensino explícito. 


\begin{abstract}
YAMAMOTO, M. J. A. F. The Lexical Approach in the systematic and explicit teaching of the lexicon for Japanese language learners in regular education setting and as a compulsory subject. 2016. 217f. Dissertação (Mestrado) - Faculdade de Filosofia, Letras e Ciências Humanas, Universidade de São Paulo, São Paulo, 2016.
\end{abstract}

The Lexical Approach (LEWIS, 1993) is distinguished by giving the lexicon the central element position in the teaching and learning process of a foreign language. It consists of principles that propose to reevaluate the importance of the lexicon and the type of treatment given to this element by teachers and learners during the process of learning the target language. In fact, this element of the language is important, since it pass through the four linguistic abilities, being configured in determinant factor for the communication. However, the complex multifaceted nature of words and the fluid reality of the lexicon make learning difficult, resulting in a lag of lexical competence. The aim of this research is to verify the contributions of systematized and explicit vocabulary teaching guided by the principles of the Lexical Approach to lexical learning in Japanese, in the short and long term, both quantitatively and qualitatively. We seek to ascertain whether complementing the incidental acquisition with the systematized and explicit teaching of the lexicon guided by the principles of the Lexical Approach contributes to the development of the lexical competence of the Japanese language learner. If so, how and to what extent? It is an empirical research of applied nature, descriptive, with quantitative approach and quasi-experimental design. In order to answer the research problem, an experiment was carried out with two classes of the sixth grade of Elementary School II of a private school in the region of Greater São Paulo. One group of participants was the experimental group and the another was the control group. A didactic sequence developed in both groups was elaborated, with the addition of four pedagogical interventions elaborated based on the principles of the Lexical Approach only in the experimental group, which were: a) a class on the concept of chunks and another on the types of lexical items; b) complementary exercises with lexical focus; c) complementary activities with lexical focus; and d) development of a lexical notebook. Shortly after the end of the didactic sequence and thirty days later, participants in both groups responded to the VKS (Vocabulary Knowledge Scale) test (WESCHE; PARIBAKHT, 1993). The data collected underwent to a statistical treatment and were analyzed descriptively an analysis of written responses was also carried out to identify evidence of a possible effect of pedagogical interventions on the performance of learners. The results of the analyzes indicated that the experimental group performed better than the control group. Based on this, it was concluded that systematized and explicit teaching guided by the principles of the Lexical Approach contributed to the development of lexical competence of the Japanese language learner in the context of teaching contemplated in this research.

Keywords: Japanese language, lexical approach, vocabulary teaching and learning, explicit teaching. 


\section{LISTA DE TABELAS}

Tabela 1 - Distribuição do número de unidades lexicais por ano escolar...............................57

Tabela 2 - Quantidade de palavras extraídas de cada corpus.

Tabela 3 - Número de palavras exigidas em cada um dos níveis do Exame de Proficiência em Língua Japonesa.

Tabela 4 - Número de sobreposição de palavras por níveis do Exame de Proficiência em Língua Japonesa.

Tabela 5 - Critérios e escalas de pontuação para atribuição de notas às intervenções.

Tabela 6 - Número e porcentagem de palavras reconhecidas no pós-teste imediato por aluno do grupo experimental.

Tabela 7 - Número e porcentagem de palavras reconhecidas no pós-teste imediato por aluno do grupo controle.

Tabela 8 - Número e porcentagem de palavras reconhecidas no pós-teste postergado por aluno do grupo experimental.

Tabela 9 - Número e porcentagem de palavras reconhecidas no pós-teste postergado por aluno do grupo controle.

Tabela 10 - Quantidade e porcentagem de cada escore no pós-teste imediato do grupo experimental.

Tabela 11 - Quantidade e porcentagem de cada escore no pós-teste imediato do grupo controle.

Tabela 12 - Quantidade e porcentagem de cada escore no pós-teste postergado do grupo experimental.....

Tabela 13 - Quantidade e porcentagem de cada escore no pós-teste postergado do grupo controle.

Tabela 14 - Alterações ocorridas entre os escores do pós-teste imediato e do pós-teste postergado do grupo experimental.

Tabela 15 - Médias dos escores do pós-teste imediato do grupo experimental

Tabela 16 - Médias dos escores do pós-teste imediato do grupo controle.

Tabela 17 - Médias dos escores do pós-teste postergado do grupo experimental.

Tabela 18 - Médias dos escores do pós-teste postergado do grupo controle.

Tabela 19 - Médias dos escores do pós-teste imediato, do pós-teste postergado e média das intervenções pedagógicas por aluno. 


\section{LISTA DE QUADROS}

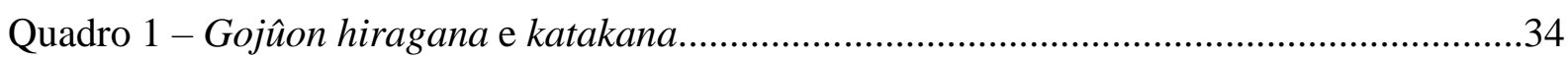

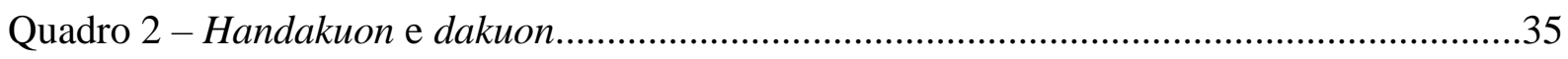

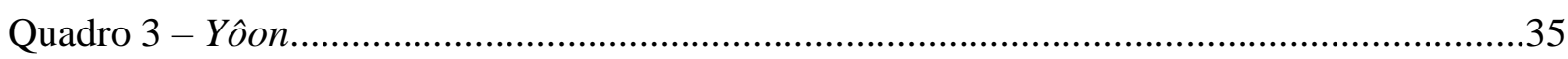

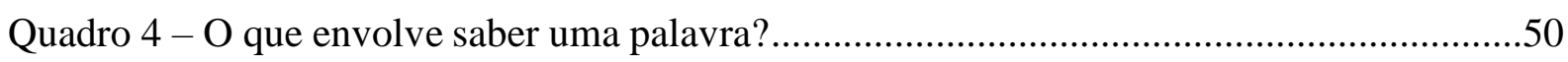

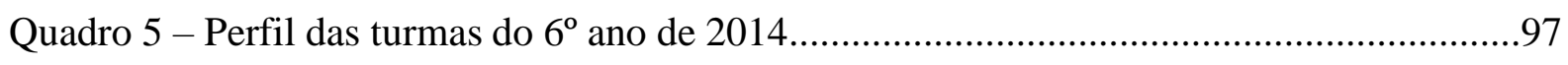

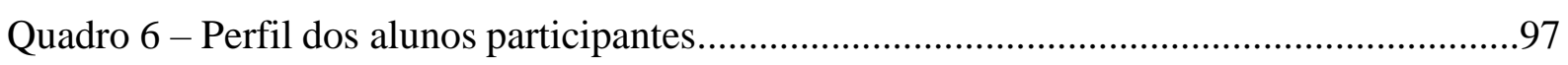

Quadro 7 - Exemplos de itens lexicais em japonês e português............................................104

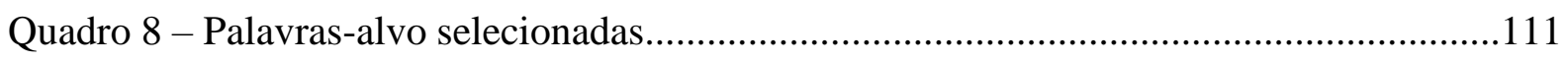

Quadro 9 - Cronograma do experimento - Grupo experimental.........................................113

Quadro 10 - Cronograma do experimento - Grupo controle..............................................114

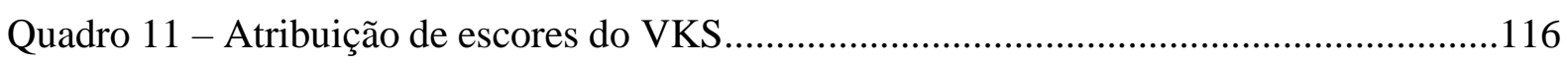

Quadro 12 - Respostas escritas da categoria V do pós-teste imediato do grupo

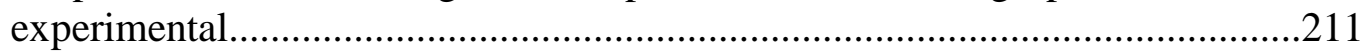

Quadro 13 - Respostas escritas da categoria V do pós-teste postergado do grupo

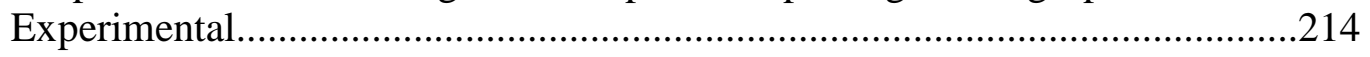

Quadro 14 - Respostas escritas da categoria V do pós-teste imediato do grupo controle.

Quadro 15 - Respostas escritas da categoria V do pós-teste postergado do grupo controle. 


\section{LISTA DE GRÁFICOS}

Gráfico 1 - Comparação da porcentagem de palavras reconhecidas no pós-teste imediato do grupo explícito e do grupo controle.

Gráfico 2 - Comparação da porcentagem de palavras reconhecidas no pós-teste postergado do grupo experimental e do grupo controle.

Gráfico 3 - Comparação entre a porcentagem de palavras reconhecidas no pós-teste imediato e no pós-teste postergado do grupo experimental.

Gráfico 4 - Comparação entre a porcentagem de palavras reconhecidas no pós-teste imediato no pós-teste postergado do grupo controle.

Gráfico 5 - Comparação da quantidade de cada escore do pós-teste imediato do grupo experimental e do grupo controle.

Gráfico 6 - Comparação da quantidade de cada escore do pós-teste postergado do grupo experimental e do grupo controle.

Gráfico 7 - Comparação da quantidade de cada escore do pós-teste imediato e do pós-teste postergado do grupo experimental.

Gráfico 8 - Comparação da quantidade de cada escore do pós-teste imediato e do pós-teste postergado do grupo controle.... 


\section{LISTA DE ABREVIATURAS E SIGLAS}

AC - Abordagem Comunicativa

AL - Abordagem Lexical

AN - Abordagem Natural

LE - Língua estrangeira

LJ - Língua japonesa

LM - Língua materna

LP - Língua portuguesa

LVB - Lista de vocabulário básico

LVdB- Lista de vocabulário de base

MAL - Método Áudio-Lingual

MD - Método Direto

MGT - Método Gramática-Tradução

$\mathrm{SE}$ - Sistema de escrita

$\mathrm{SF}$ - Sistema fonético

VKS - Vocabulary Knowledge Scale (Escala de Conhecimento Vocabular)

LH - Língua de herança

JLPT - Japanese Language Proficiency Test

PTI - Pós-teste imediato

PTT - Pós-teste postergado

GE - Grupo experimental

GC - Grupo controle

EI - Educação Infantil

EFI - Ensino Fundamental I

EFII - Ensino Fundamental II

EM - Ensino Médio 


\section{SISTEMA DE TRANSLITERAÇÃO ADOTADO}

O sistema de transliteração adotado é shûsei hebon-shiki. Os sons romanizados devem ser lidos de acordo com as seguintes orientações (adaptado de AKAMINE, 2012):

h: som aspirado, como em hot dog

n: sílaba anasalada

r: consoante vibrante alveolar, como em coroa, aurora

s: som sibilante, como o "ss" ou "ç" do português

w: semivogal com som equivalente ao "u" do português

sh: som de "x" ou "ch" do português, como em chuchu

ja, ju, jo: som palatalizado

cha,chu, cho: som palatalizado, como o som de "tch" em tchau

rya, ryu, ryo: som contraído

Repetição de consoante (kk, tt, pp): sílaba glotalizada ou ejectiva

Sinal ^${ }^{\wedge}$ alongamento da vogal 


\section{SUMÁRIO}

I - INTRODUÇÃ

1.1 Breve histórico do ensino de língua japonesa no Brasil............................................15

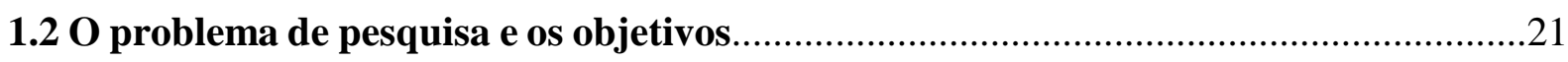

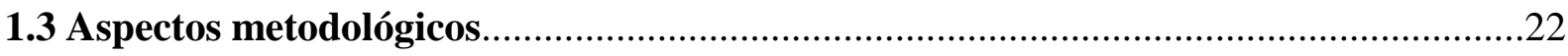

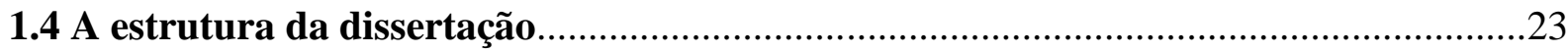

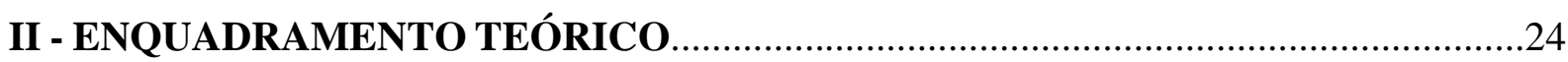

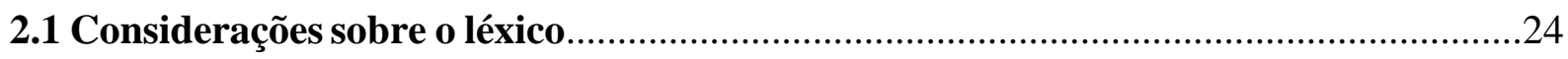

2.1.1 A importância do léxico no ensino-aprendizagem de LE............................................24

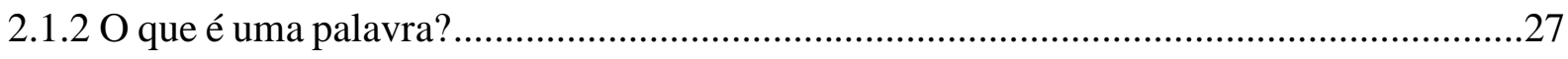

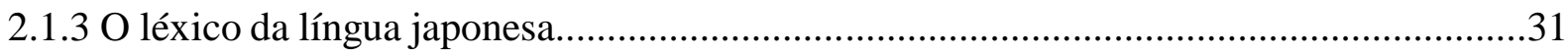

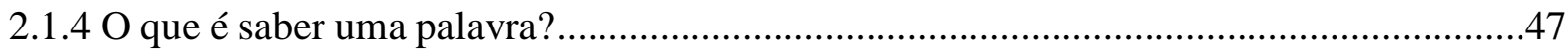

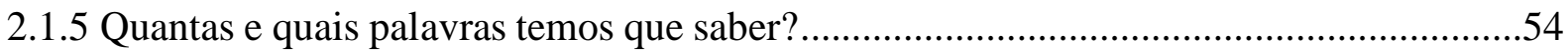

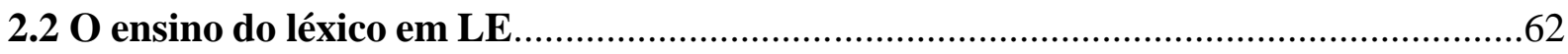

2.2.1 O tratamento dado ao léxico nos métodos de ensino de LE.........................................62

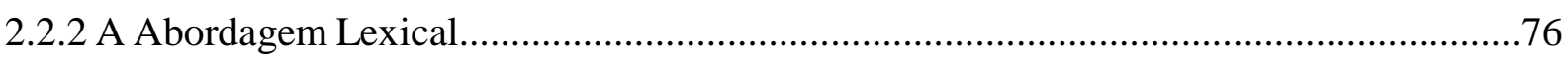

2.2.3 O léxico da língua japonesa do ponto de vista da Abordagem lexical............................82

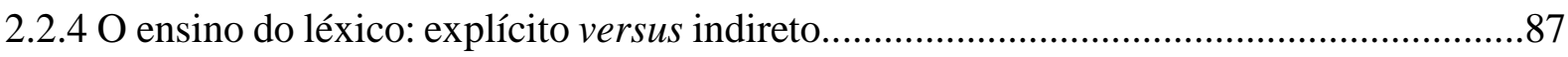

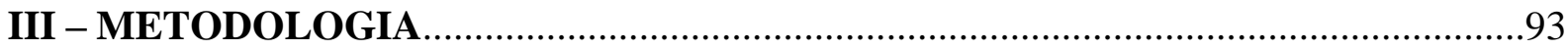

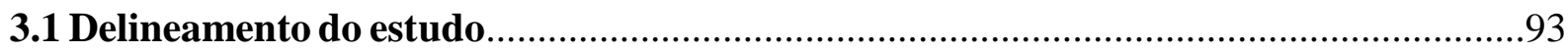

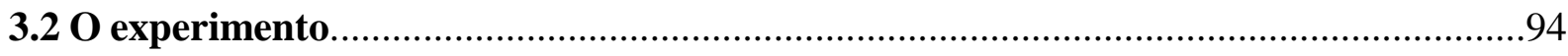

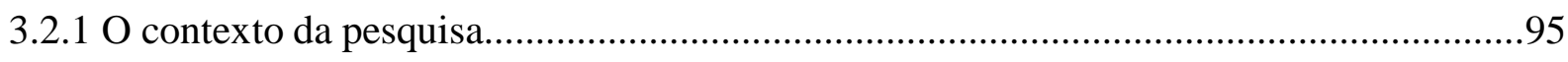

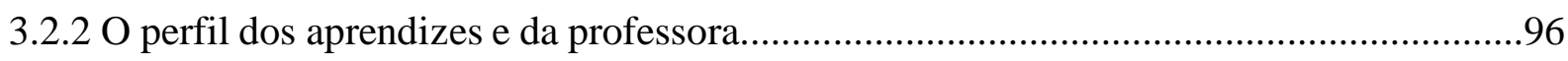

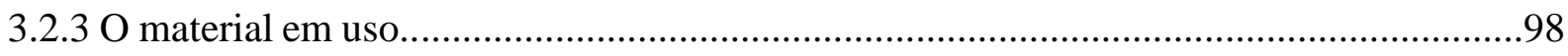

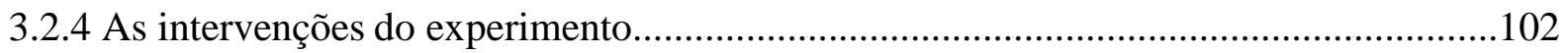

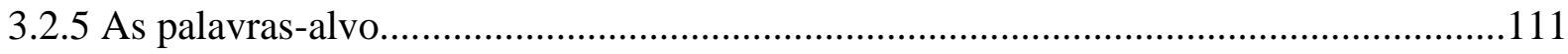

3.2.6 $\mathrm{O}$ cronograma e o planejamento simplificado das aulas...............................................112

3.3 Instrumento de coleta de dado: Escala de Conhecimento Vocabular (VKS)............114

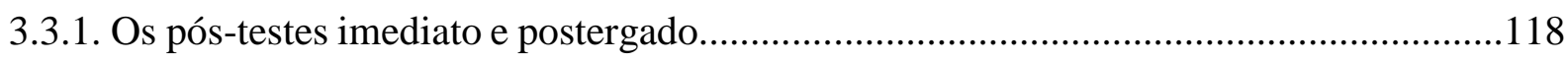

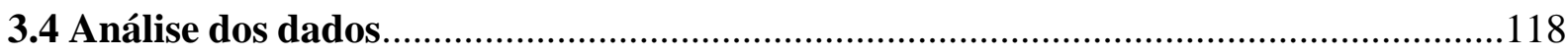

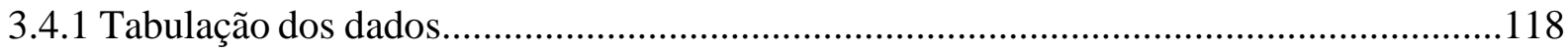


3.4.2 Atribuição de notas às intervenções. 119

3.4.3 Análise estatística

3.4.4 Os testes estatísticos

3.4.5 Análise das respostas escritas.

IV - APRESENTAÇÃO, ANÁLISE E DISCUSSÃO DOS RESULTADOS.

4.1 Análise estatística descritiva dos escores simplificados.

4.1.1 Pós-teste imediato

4.1.2 Pós-teste postergado

4.1.3 Comparação entre o pós-teste imediato e o pós-teste postergado dos grupos experimental e controle.

4.2 Análise estatística descritiva dos escores reais

4.2.1 Pós-teste imediato

4.2.2 Pós-teste postergado

4.2.3 Comparação entre o pós-teste imediato e o pós-teste postergado do grupo experimental e do grupo controle

4.2.4 Análise estatística descritiva das médias dos escores do pós-teste imediato do grupo experimental e do grupo controle.

4.2.5 Análise estatística descritiva das médias dos escores do pós-teste postergado

do grupo experimental e do grupo controle

4.2.6 Análise estatística descritiva entre as médias do pós-teste imediato e do pós-teste postergado dos grupos experimental e controle. 140

4.2.7 Análise do Coeficiente de correlação de Spearman. 140

4.3 Análise das respostas escritas dos testes 142

V - CONSIDERAÇÕES FINAIS E CONCLUSÃO 145

5.1 Limitações do estudo. 148

REFERÊNCIAS BIBLIOGRÁFICAS. 149

ANEXOS. 155

ANEXO A - What is involved in knowing a word. 155

ANEXO B - Imagens utilizadas na primeira intervenção. 156

ANEXO C - Teste de Familiaridade 


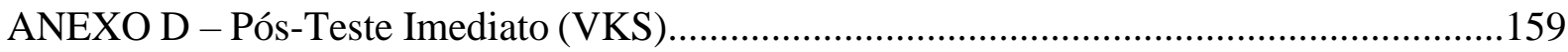

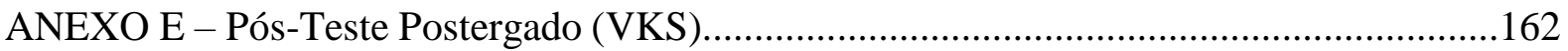

ANEXO F - Teste de Wilcoxon para duas amostras independentes................................... 165

ANEXO G - Teste de Wilcoxon para duas amostras independentes....................................166

ANEXO H - Teste de Wilcoxon Pareado.............................................................................167

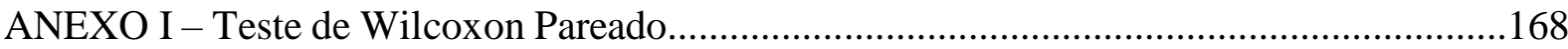

ANEXO J - Teste de Wilcoxon para duas amostras independentes.....................................169

ANEXO K - Teste de Wilcoxon para duas amostras independentes.....................................170

ANEXO L - Teste de Wilcoxon Pareado..........................................................................171

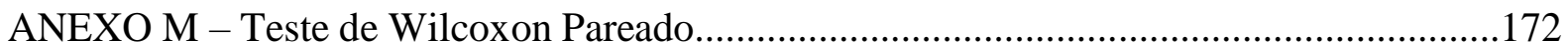

ANEXO N - Coeficiente de Correlação de Spearman............................................................173

ANEXO O - Coeficiente de Correlação de Spearman............................................................174

ANEXO P - Coeficiente de Correlação de Spearman...........................................................175

APÊEDICES

APÊNDICE A - Termo de autorização institucional............................................................176

APÊNDICE B - Termo de Consentimento Livre e Esclarecido.............................................178

APÊNDICE C - Planos de Aula....................................................................................180

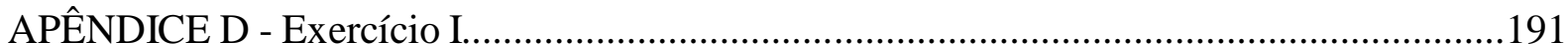

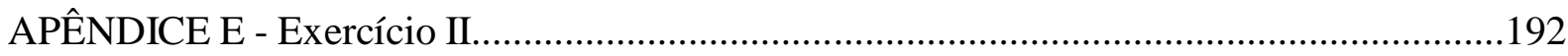

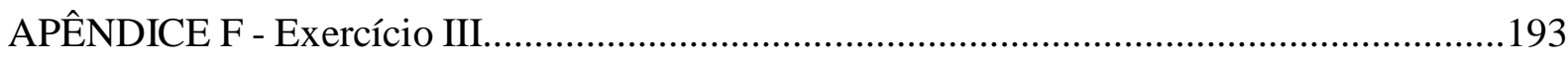

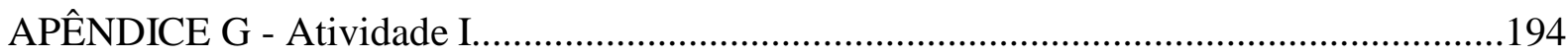

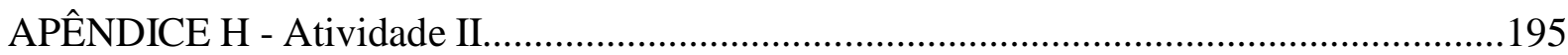

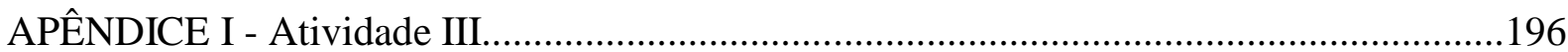

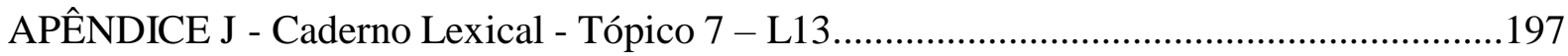

APÊNDICE K - Caderno Lexical - Tópico 7 - L14 .............................................................203

APÊNDICE L - Escores Simplificados Grupo Experimental..............................................207

APÊNDICE M - Escores Simplificados Grupo Controle.....................................................208

APÊNDICE N - Escores Reais Grupo Experimental..........................................................209

APÊNDICE O - Escores Reais Grupo Controle...............................................................210

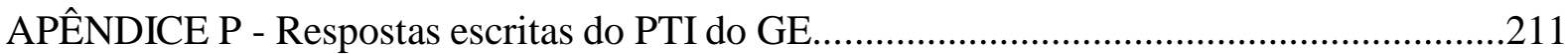

APÊNDICE Q - Respostas escritas do PTP do GE............................................................214

APÊNDICE R - Respostas escritas do PTI do GC..............................................................216

APÊNDICE S - Respostas escritas do PTP do GC..............................................................217 


\section{INTRODUÇÃO}

\subsection{Breve histórico do ensino de língua japonesa no Brasil}

O ensino de língua japonesa (LJ) no Brasil teve início com a chegada dos imigrantes japoneses em 1908. Nesses 108 anos de história, passou por diversas mudanças influenciadas pelas características do cenário sócio-político de cada fase.

Ao desembarcarem no porto de Santos, os japoneses seguiram para os campos de lavoura no interior do Brasil. Enfrentaram a frustação com as condições de vida e de trabalho, problemas com as diferenças culturais e dificuldade de se relacionar com os brasileiros em função do entrave da língua. O desejo dos imigrantes era prosperar na terra prometida e retornar ao Japão. Por essa razão, preocupavam-se em manter os hábitos e os costumes para preservar o "espírito japonês”. (MORIWAKI, 2008).

Segundo Morales (2008, p.25), no período pré-guerra viviam em circunstância de "monolinguismo em situação de isolamento", pois entre os imigrantes se usava apenas o japonês e as crianças eram educadas como se estivessem no Japão, para se tornarem cidadãos japoneses. $\mathrm{O}$ ensino da língua era visto como uma forma de manter a identidade japonesa. De acordo com Moriwaki (2008, p.17) “o ensino de língua japonesa no Brasil não significava em si nem objetivo nem meio, mas a expressão de um 'princípio filosófico"”.

Desse modo, nessa fase, a LJ era ensinada como LM. Os filhos dos imigrantes a adquiriam naturalmente em casa e frequentavam as escolas japonesas mantidas pelas comunidades para aprenderem a ler e a escrever, bem como sobre a cultura do Japão.

O material didático adotado eram os chamados Kokugo kyôkasho, livros usados nas escolas do Japão nas aulas de kokugo $^{1}$ (língua nacional). Os professores eram voluntários e poucos tinham formação voltada para a docência. Uma vez que a L1 das crianças era o japonês, as aulas restringiam-se a leitura de textos e a aprendizagem dos ideogramas (MORALES, 2008, p.39).

Após o término da guerra, os imigrantes começaram a prosperar na agricultura e no comércio, o que os levou a abandonar a ideia de retorno à terra natal. Os filhos passaram a frequentar as escolas brasileiras em um período e no outro a escola japonesa, em um regime

\footnotetext{
${ }^{1} \mathrm{O}$ termo kokugo kyôiku se refere ao ensino de língua japonesa no Japão, como língua nacional. Já o termo nihongo kyouiku se refere ao ensino de língua japonesa como língua estrangeira (HOSOKAWA, 1999).
} 
de escolarização bilíngue. Nessa fase, a LJ passa à condição de língua de herança (LH), a qual Morales define como:

LH frequentemente aplicado à L1 da criança que sofreu deslocamento geográfico e perde o ambiente linguístico da L1 ou o caso de filhos de imigrantes de segunda e terceira geração que aprende a língua dos pais e/ou avós no domínio familiar que não é a língua majoritária dos pais (MORALES, 2008, p.26)

Na condição de LH, o japonês continuou a ser ensinado com foco na leitura e na escrita, pois o desenvolvimento da habilidade oral ficava a cargo da família, sendo o professor isento da responsabilidade de trabalhar esse aspecto nas aulas.

Com relação ao material didático, nesse período grande parte das escolas japonesas adotaram livros didáticos de japonês que começaram a ser produzidos no Brasil, os quais introduziam particularidades do contexto de ensino e buscavam atender ao público-alvo de crianças nipo-brasileiras (MORALES, 2008, p. 86).

A partir do momento em que as crianças japonesas passaram a receber instrução formal na língua majoritária, teve início o enfraquecimento da LH e a natural transição para a competência linguística em língua portuguesa (MORALES, 2008, p.66). As crianças descendentes da terceira geração (sansei) não eram mais falantes de LJ, exigindo dos professores uma nova perspectiva para o ensino dessa língua. Somado a isso, não descendentes de japoneses também começaram a ter interesse em aprender o japonês. Consequentemente, aprendizes com conhecimento zero de LJ passaram a frequentar as aulas, o que não ocorria antes, quando ensinada na condição LM e/ou LH (MORIWAKI, 2008). O novo perfil de aprendiz demandava uma nova metodologia de ensino que os levasse a desenvolver as quatro habilidades linguísticas. Com isso, deu-se início ao ensino de LJ como língua estrangeira (LE).

Atualmente, no Brasil, o ensino de LJ é oferecido em associações culturais nipobrasileiras e em cursos livres particulares. Também é oferecido na rede oficial de ensino, distribuído da seguinte forma: em 24 Centros de Estudos de Línguas (CEL) de São Paulo; em três Centros Interescolares de Línguas (CIL) de Brasília; em sete Centros de Línguas Estrangeiras Modernas (CELEM) do Paraná; em 27 escolas particulares de ensino básico regular de diversas localidades do Brasil; em oito universidades como curso de graduação, em 17 como curso de extensão universitária e em duas como matéria optativa (FUNDAÇÃO JAPÃO, 2015).

Ao nosso ver, a transição do ensino de LJ como LE no Brasil ainda está em andamento, visto que em muitos desses contextos é possível observar a adoção de abordagens 
e metodologias de ensino inadequadas ao novo perfil dos aprendizes, as quais negligenciam aspectos essências para o desenvolvimento da competência comunicativa do aprendiz em prol do estudo dos aspectos formais da língua.

Segundo Morales (2008, p.97), "no Brasil, por muito tempo, o ensino de japonês ficou bastante circunscrito aos descendentes, o que fez com que os professores se sentissem dispensados de aprimorar a metodologia de LE”. Tendo em vista que muitos dos professores em ação atualmente são os mesmos que ensinavam a LJ na condição de LH, ou são descendentes que aprenderam/estudaram a LJ como LH, ou seja, a partir de uma abordagem estruturalista, é compreensível o atual desajuste entre as necessidades dos aprendizes e as abordagens e metodologias em vigor.

Dentre os aspectos negligenciados, consideramos relevante refletir sobre o ensino do léxico. A defasagem da competência lexical na língua-alvo é um dos obstáculos para o desenvolvimento da competência comunicativa do aprendiz, uma vez que a compreensão e execução das quatro habilidades linguísticas (ouvir, ler, falar e escrever) estão condicionadas ao conhecimento do léxico da língua em estudo.

No entanto, conforme observou Zimmerman (1997) em seu trabalho de resumo da história das metodologias de ensino de LE, sempre houve uma priorização na aprendizagem dos elementos gramaticais e fonéticos da língua-alvo, mas pouco se falou sobre o estudo do léxico $^{2}$. Duas razões podem ser atribuídas a essa indiferença: a primeira é o entendimento equivocado de que saber uma palavra em LE significa unicamente saber seu correspondente na LM. Nation discorda e afirma que:

As palavras não são unidades isoladas da linguagem, mas se encaixam em muitos sistemas e níveis relacionados. Devido a isso, há muitas coisas para se saber sobre qualquer palavra em particular e há muitos níveis de conhecimento (2013, p.44 tradução nossa). ${ }^{3}$

Isto é, para o autor, saber uma palavra abrange uma gama de conhecimentos sobre sua forma, seu significado e seu uso. Na mesma linha de pensamento, Scaramucci entende conhecimento lexical como:

[...] adoto o conceito de conhecimento lexical, que incorpora vários aspectos especificados no conceito rico, ou seja, os níveis lexicais, sintático, morfológico, semântico, ao qual adiciono um nível discursivo/pragmático, incorporando à

\footnotetext{
${ }^{2}$ Segundo Vilela (1994, p.10), o léxico diz respeito à totalidade de palavras de uma língua, já o vocabulário à porção desse léxico que representa uma determinada área de conhecimento. Nesse trabalho, as palavras vocabulário e léxico são empregadas de acordo com essa concepção.

${ }^{3}$ Words are not isolated units of the language, but fit into many related systems and levels. Because of this, there are many things to know about any particular word and there are many degrees of knowing.
} 
dimensão linguística também uma dimensão de uso, ou cognitiva, ao invés de considerá-la separadamente, levando-se em conta a interação entre elas (1997, p.1).

A outra razão se refere à ideia presente em muitos contextos de ensino ainda hoje de que as palavras da língua-alvo são adquiridas gradualmente, conforme são expostas ao aprendiz. A aprendizagem incidental ou indireta de vocabulário tem embasamento na teoria de Aquisição de Segunda Língua proposta por Krashen (1981), pela qual o autor defende, entre outros pontos, que a exposição a textos compreensíveis e significativos é o suficiente para a aquisição de vocabulário (SCARAMUCCI; GATTOLIN, 2007, p.9).

No caso do ensino-aprendizagem de LJ, podemos observar que esse pensamento também está presente ao analisarmos os materiais didáticos mais comumente utilizados. De acordo com a última pesquisa da Fundação Japão (2015) sobre as instituições regulares de ensino de LJ do Brasil, atualmente em muitos contextos se utiliza livros didáticos elaborados a partir de uma visão estruturalista da língua ${ }^{4}$. À vista disso, podemos deduzir a ocorrência da supervalorização do ensino da estrutura da língua-alvo. Nesses materiais vemos que não há momentos de esforço direcionado ao trabalho com o vocabulário, indicando uma possível marginalização do léxico também no ensino de LJ como LE.

Além disso, parece-nos que professores e aprendizes acreditam estar ensinando/aprendendo vocabulário enquanto estudam os sistemas de escrita da LJ, em especial os ideogramas. Obviamente, parte do que se precisa saber sobre uma palavra é aprendida, mas não são contemplados todos os aspectos.

Desde meados dos anos 70, o léxico passou a ter mais visibilidade, culminando em estudos que defendem a importância de um ensino sistemático do mesmo. Laufer ${ }^{5}$ (1997, p. 140 - tradução nossa) resume a importância da valorização do léxico na seguinte fala:

O vocabulário não é mais uma vítima de discriminação na pesquisa em aprendizagem de segunda língua, ou no ensino de língua. Após décadas de negligência, o léxico é hoje reconhecido como central em qualquer processo de aquisição de linguagem nativa ou não nativa. O que muitos professores de língua talvez intuitivamente já sabiam por muito tempo, que um vocabulário consistente é necessário em todos os estágios de aquisição de segunda língua, está sendo abertamente dito por alguns pesquisadores em aquisição de segunda língua.

\footnotetext{
${ }^{4}$ Por exemplo, os livros da série Minna no Nihongo ( $3^{\text {a }}$ Corp, 1998), os mais citados na pesquisa, na categoria de materiais didáticos comerciais. Também há um número considerável de instituições que alegam utilizar materiais de produção própria.

${ }^{5}$ Vocabulary is no longer a victim of discrimination in second language learning research, nor in language teaching. After decades of neglect, lexis is now recognized as central to any language acquisition process, native or non-native. What many language teachers might have intuitively known for a long time, that a solid vocabulary is necessary in every stage of language learning, is now being openly stated by some second language acquisition (SLA) researchers.
} 
McCarthy $^{6}$ (apud LAUFER, 1997, p. 140 - tradução nossa) argumenta a favor do léxico afirmando que o conhecimento das regras gramaticais e dos sons de uma língua não garantem por si só a comunicação, pois “[...] sem palavras para expressar uma gama maior de significados, a comunicação em L2 simplesmente não pode acontecer de uma maneira significativa"?.

Como resultado desse movimento pró-léxico, despontam estudos que colocam em cheque a autossuficiência da aprendizagem incidental de vocabulário e advogam a favor do ensino explícito do léxico. Sobre o assunto, Nation afirma:

Esta é a vertente de aprendizagem centrada na língua, às vezes chamada de instrução centrada na forma. Há evidências crescentes (ELLIS, 2005, WILLIAMS, 2005) de que a aprendizagem de línguas se beneficia se houver uma quantidade apropriada de ensino deliberado de itens da língua. Do ponto de vista do vocabulário, isso significa que um curso deve envolver o ensino, a aprendizagem e o estudo explícito de vocabulário. [...] há uma quantidade muito grande de pesquisas que remontam ao final do século XIX, as quais mostram que o processo cumulativo gradual de aprendizagem de uma palavra pode ser impulsionado pelo estudo direto de certas características da palavra $\left(2013\right.$, p.2). ${ }^{8}$

Tendo em vista a complexidade do léxico da LJ, alinhamo-nos aos pesquisadores que consideram indispensável complementar a aprendizagem incidental de vocabulário com o ensino sistematizado e explícito do léxico da língua-alvo. Em nossa prática docente, uma das mais frequentes reclamações de alunos é a dificuldade em manter, ampliar e acessar as palavras da LJ, bem como manipulá-las de maneira adequada em cada situação comunicativa. Essas queixas são a principal motivação deste trabalho.

Após vasta pesquisa em bancos de dados dos programas de pós-graduação do país, periódicos nacionais e internacionais e de universidades do exterior, encontramos um número reduzido de trabalhos que tratam do assunto na área de ensino de LJ. O mesmo foi observado por Yachi (2002, p.1 - tradução nossa):

No entanto, quase não há pesquisas no Japão sobre o processo percorrido na aquisição de vocabulário ou quais pontos desse processo são conflitantes para os aprendizes de língua japonesa como língua estrangeira. Nos últimos anos, também no Japão vem ocorrendo pesquisas sobre aquisição de vocabulário, mas Nagatomo

${ }^{6}$ McCARTHY, M. Vocabulary. Oxford: Oxford University Press, 1990.

${ }^{7}[\ldots]$ without words to express a wide range of meanings, communication in an L2 just cannot happen in any meaningful way.

${ }^{8}$ This is the strand of language-focused learning, sometimes called form-focused instruction. There is growing evidence (ELLIS, 2005; WILLIAMS, 2005) that language learning benefits if there is an appropriate amount of usefully focused deliberate teaching and learning of language items. From vocabulary perspective, this means that a course should envolve the direct teaching of vocabulary and the direct learning and study of vocabulary. [...] there is a very large amount of research stretching back to the late 19th century which shows that the gradual cumulative process of learning a word can be given a strong boost by the direct study of certain features of the word. 
(1999) aponta que a aquisição de vocabulário em língua japonesa como língua estrangeira é um campo inexplorado nas pesquisas da área9 .

Frente a tal constatação, inicialmente nos dedicamos a uma pesquisa bibliográfica a fim de entender parte de nosso objeto de estudo, o léxico, e conhecer estudos anteriores sobre o ensino sistematizado e explícito de vocabulário e sua relação com o desenvolvimento da competência lexical em LE. Baseados nesse estudo preliminar, desenvolvemos uma investigação com o objetivo de verificar as contribuições da Abordagem Lexical (AL) para o ensino sistematizado e explícito de vocabulário em LJ. Optamos por essa abordagem em função de sua principal característica: o léxico é visto como o elemento central no ensinoaprendizagem de LE. Michel Lewis, autor da AL, define-a da seguinte maneira:

\begin{abstract}
A abordagem lexical desenvolve muitos dos princípios fundamentais lançados pelos defensores das Abordagens Comunicativas. A diferença mais importante é o aumento da compreensão da natureza do léxico que ocorre na linguagem natural, e sua potencial contribuição para a pedagogia da linguagem. ${ }^{10}$ (LEWIS, 1993, p.VI tradução nossa).
\end{abstract}

Como mencionado pelo próprio autor, a AL compartilha de muitos dos princípios da Abordagem Comunicativa. Sua inovação está na proposta de deslocamento da ênfase na estrutura para a ênfase no léxico. Lewis afirma que o léxico, ao invés da estrutura, é a base da língua.

Dessa forma, nesta pesquisa tratamos sobre o ensino sistematizado e explícito de vocabulário em LJ como LE norteado pelos princípios da AL.

\title{
$1.2 \mathrm{O}$ problema de pesquisa e os objetivos
}

Embora esse seja um problema facilmente observável durante a prática pedagógica, pouco se fala sobre o vocabulário do ponto de vista didático-metodológico na área de ensino de LJ como LE. Os professores confiam essa tarefa ao material didático e se apegam à crença de que as novas palavras serão adquiridas conforme surgirem e, por isso, não há necessidade

\footnotetext{
${ }^{9} し$ し、学習者が実際にはどのような過程を経て語彙を習得しているのか、学習者にとって、どの ようなてんが学習困難なのかということについては、日本ではあまり研究が行われていない。近年で は日本でも語彙習得研究が行われてきているが、長友（１９９９）は、日本で行われた第二言語とし ての日本語の語彙習得研究は習得研究の実開拓の分野であることを指摘している。

10 "The Lexical Approach develops many of the fundamental principles advanced by proponents of Communicatives Approaches. The most important difference is the increased understanding of the nature of lexis in naturally occurring language, and its potential contribution to language pedagogy."
} 
de se preocupar com a ensino desse aspecto da língua. Já os materiais didáticos se restringem ao vocabulário que seja relevante ao conteúdo abordado em cada lição e esperam que o professor observe as necessidades dos aprendizes e acrescente ou aprofunde o conhecimento de palavras que sejam interessantes para a realidade deles.

Como consequência desse jogo de "ping-pong", vemos, por fim, que nada é feito de concreto para o desenvolvimento da competência lexical do aprendiz. Outro agravante é a visão distorcida do que seja aprender o léxico da $\mathrm{LJ}$, em decorrência do fato de ambas as línguas, português e japonês, não compartilharem o mesmo sistema de escrita. Professores e alunos tendem a acreditar que ao ensinarem/aprenderem o sistema de escrita da LJ, devido a sua natureza e funcionamento, já estão, simultaneamente, desenvolvendo a competência lexical de maneira suficiente. No entanto, aprender novas palavras em uma LE não se resume a encontrar correspondentes na LM, ou seja, o estudo do sistema de escrita não é suficiente, pois proporciona apenas uma parte da gama de conhecimentos que compõem uma palavra.

À vista disso, sentimos a necessidade de buscar alternativas didático-metodológicas para o ensino do léxico da LJ e culminamos no seguinte problema de pesquisa: "O ensino sistematizado e explícito norteado pelos princípios da AL contribui para a aprendizagem do léxico da língua japonesa? Se sim, de que forma e em que medida?

Dessa forma, o objetivo geral dessa pesquisa é verificar as contribuições do ensino sistematizado e explícito de vocabulário norteado pelos princípios da AL para a aprendizagem do léxico em LJ, a curto e longo prazo, tanto quantitativamente quanto qualitativamente.

\subsection{Aspectos metodológicos}

Trata-se de uma pesquisa empírica, de natureza aplicada, descritiva, com abordagem quantitativa e delineamento quase-experimental. Para respondermos ao nosso problema de pesquisa, realizamos um experimento com participantes de duas turmas do sexto ano do Ensino Fundamental II de uma escola particular, uma foi escolhida como grupo experimental e a outra como grupo controle. Elaboramos uma sequência didática desenvolvida nos dois grupos, com a adição de intervenções pedagógicas apenas no grupo experimental. As intervenções foram uma aula sobre o conceito de chunks e outra sobre os tipos de itens lexicais, exercícios e atividades extras com foco lexical; e a produção de um caderno lexical.

Baseados em nosso problema de pesquisa, formulamos a seguinte hipótese a ser testada no experimento: complementar a aquisição incidental com ensino sistematizado do 
léxico via instrução direta contribui para o desenvolvimento de uma competência lexical sólida composta por um conhecimento rico de vocabulário. Para verificarmos essa hipótese, definimos as seguintes perguntas a serem respondidas a partir da análise dos dados coletados:

1) O ensino sistematizado e explícito de vocabulário norteado pelos princípios da $\mathrm{AL}$ contribui para a aprendizagem do vocabulário da LJ do ponto de vista quantitativo?

2) O ensino sistematizado e explícito de vocabulário norteado pelos princípios da AL contribui para a aprendizagem de vocabulário da LJ do ponto de vista qualitativo?

3) O ensino sistematizado e explícito de vocabulário norteado pelos princípios da $\mathrm{AL}$ contribui para a aprendizagem de vocabulário da LJ a curto e longo prazo?

Ao final da sequência didática e trinta dias depois, os participantes de ambas as turmas responderam ao teste Vocabulary Knowledge Scale (WESCHE; PARIBAKHT, 1993). Os dados coletados passaram por um tratamento estatístico e foram analisados descritivamente. Realizamos também uma análise das respostas escritas, com o objetivo de identificar evidências de um possível efeito das intervenções baseadas na AL no desempenho dos aprendizes.

\subsection{A estrutura da dissertação}

Esta dissertação está organizada em cinco capítulos. Na introdução, Capítulo I, apresentamos um breve histórico do ensino de LJ no Brasil, o processo de formação do problema de pesquisa, os objetivos e os aspectos metodológicos.

O Capítulo II se refere ao enquadramento teórico deste estudo, no qual abordamos questões relevantes sobre o ensino-aprendizagem do léxico em LE; apresentamos as características do léxico da LJ; discorremos sobre a discussão a respeito da aprendizagem intencional versus aprendizagem incidental de vocabulário; e apresentamos a Abordagem Lexical.

No Capítulo III descrevemos a metodologia empregada nesta investigação e no Capítulo IV apresentamos, analisamos e discutimos os dados coletados.

Por fim, no Capítulo V se encontram as considerações finais e as limitações desta pesquisa. 


\section{II - ENQUADRAMENTO TEÓRICO}

Neste capítulo se encontra o embasamento teórico desta pesquisa. Em um primeiro momento, discutimos questões basilares referentes ao componente linguístico léxico e, mais especificamente, apresentamos as características e particularidades do léxico da LJ. Em seguida, discutimos proposições pertinentes à reflexão sobre o ensino-aprendizagem do léxico da LJ.

\subsection{Considerações sobre o léxico}

Qualquer proposta de estudo acerca do léxico de uma língua, seja qual for o foco, demanda uma discussão prévia sobre as características essenciais desse elemento linguístico. Além disso, se a pesquisa se encontra na área de ensino-aprendizagem de LE, outros questionamentos básicos também surgem. Nas subseções seguintes apresentamos algumas considerações sobre o conceito de léxico e sobre o léxico da LJ que consideramos serem relevantes para o entendimento de nosso objeto de estudo.

\subsubsection{A importância do léxico no ensino-aprendizagem de LE}

Aprender uma LE é uma tarefa trabalhosa que demanda tempo e dedicação. O objetivo final é tornar o aprendiz apto a manejar os vários aspectos da língua-alvo, de acordo com as exigências da situação comunicativa.

Durante anos, pesquisou-se sobre como alcançar esse objetivo de forma mais rápida e eficiente. No entanto, as pesquisas se limitaram, por um bom tempo, à busca de respostas no estudo de questões didático-metodológicas relacionadas à fonética e à gramática, revelando a crença de que o sucesso estaria no domínio desses elementos da língua-alvo. Aos poucos, o cenário se expandiu e a noção do que é necessário para dominar uma LE foi reformulada (SCARAMUCCI, 1995). Hoje, entende-se como objetivo final o alcance de uma competência comunicativa, na qual se inserem as competências linguística, estratégica, sociolinguística, acional e discursiva. O conceito competência comunicativa foi inicialmente cunhado por Dell 
Hymes (1972) e expandido por Canale e Swain (1980), Canale (1983) e Celce-Murcia, Dörnyei e Thurrell (1995).

Consequentemente, o horizonte das pesquisas sobre ensino-aprendizagem de LE sofreu um relevante alargamento e deu origem ao Movimento do Ensino Comunicativo de Línguas, do qual derivou-se a Abordagem Comunicativa (AC). Todavia, um importante elemento da língua-alvo ainda permaneceu em segundo plano: o léxico. A competência comunicativa situa o léxico na competência linguística, como um atributo de algo maior. Os princípios da $\mathrm{AC}$, de fato, orientaram mudanças de ordem metodológica no ensino do léxico no sentido de sugerir o abandono das listas de palavras e da prática da mera memorização, em prol de um ensino contextualizado e significativo. No entanto, ainda era notável a negligência, tendo em vista a ausência de discussões mais aprofundadas sobre o léxico em si e de seu papel no processo de ensino-aprendizagem de LE (MEARA, 1980, p.221).

A partir dos anos 70, esse cenário começa a mudar. Diversos autores se mostram cientes dessa lacuna e passam a reconhecer que o conhecimento lexical é imprescindível para a aprendizagem de uma LE (RICHARDS, 1976, KRASHEN; TERRELL, 1983; ELLIS, 1994; SCARAMUCCI, 1995; ZIMMERMAN, 1997; LEFFA, 2000; SCARAMUCCI; GATTOLIN, 2007, entre outros).

Leffa (2000, p.40) defende que a melhor maneira de se aprender o complexo sistema de uma língua, composto pelos diversos aspectos acima citados, é enfatizando o vocabulário, "porque todos os outros aspectos, da fonologia à pragmática, decorrem naturalmente de componentes que estão dentro das palavras". O autor ainda coloca que:

\begin{abstract}
Se alguém, ao estudar uma língua estrangeira, fosse obrigado a optar entre o léxico e a sintaxe, certamente escolheria o léxico: compreenderia mais um texto identificando seu vocabulário do que conhecendo sua sintaxe. Da mesma maneira, se alguém tiver que escolher entre um dicionário e uma gramática para ler um texto numa língua estrangeira, certamente escolherá o dicionário. Língua não é só léxico, mas o léxico é o elemento que melhor a caracteriza e a distingue das outras. (LEFFA, 2000, p.17).
\end{abstract}

Widdowson (1978 apud ZIMMERMAN, 1997, p.13 - tradução nossa) ${ }^{11}$ corrobora o valor do léxico ao declarar que "nativos podem entender melhor afirmações com erros gramaticais, mas com vocabulário preciso, do que afirmações gramaticalmente corretas, mas com vocabulário inadequado"12

\footnotetext{
${ }^{11}$ WIDDOWSON, H. G. Teaching English as Communication. Oxford: Oxford University Press, 1978.

12 Widdowson (1978) is claimed that native speakers can better understand ungrammatical utterance with accurate vocabulary than those with accurate grammar and inacurate vocabulary".
} 
Meara assinala, ao nosso ver, a indicação mais contundente da relevância do léxico no processo de ensino-aprendizagem da língua-alvo: a preocupação dos próprios aprendizes. Segundo o autor, o léxico é apontado pelos aprendizes como uma das principais dificuldades na aprendizagem de uma LE:

\begin{abstract}
Os próprios aprendizes são os primeiros a identificar os problemas lexicais como sendo sua maior fonte de problemas na segunda língua, e essa autoavaliação é sustentada por grandes coletas de erros que - como o corpus Utrecht - mostram, de maneira consistente, que os erros lexicais superam os erros gramaticais na razão de três ou quatro por um (MEARA, 1984, p. 229 - tradução nossa). ${ }^{13}$
\end{abstract}

A Psicolinguística também contribui para o movimento de valorização do léxico ao abordar a questão do ponto de vista do processamento da linguagem, através do modelo de produção de fala de Levelt (1989). O autor defende que os processos de formulação -inclusive a codificação gramatical e a fonológica - se fundamentam no léxico, fato esse que condiciona a construção do discurso ao acesso às unidades lexicais em nosso léxico mental. O léxico é tido como um mediador entre a conceitualização e a codificação gramatical e fonológica. Tal pressuposição deu origem à hipótese lexical, a qual garante que nenhuma forma sintática será ativada sem a intermediação de unidades lexicais, pois são as características gramaticais do léxico que permitem que o codificador gramatical elabore uma estrutura sintática (NATION, 2013, p.62).

Gass e Selinker (1994, p. 449) sumarizam todos os argumentos pró-léxico citados ao argumentarem que os erros de vocabulário são considerados os mais sérios pelos aprendizes e os que são mais comumente cometidos. Além disso, os autores afirmam que o léxico é a força motriz da produção de sentenças, bem como elemento importante para a compreensão.

Apesar da evidente importância do léxico, seu ensino-aprendizagem ainda ocorre de forma assistemática, sem planejamento e controle, fato possivelmente decorrente da crença de que um trabalho pontual é desnecessário, já que esse é adquirido naturalmente com o tempo, conforme o aprendiz é exposto a novos insumos linguísticos. Candlin, no prefácio do livro Vocabulary and Language Teaching de Carter e McCarthy (1988), alertou sobre o fato de que o ensino do léxico não é considerado uma área independente das outras, estando sempre vinculado à leitura e a escrita, por isso não tem uma identidade própria.

Diante do exposto, podemos entender que o conhecimento lexical é fator essencial para o desenvolvimento da competência comunicativa e a plena execução das quatro

\footnotetext{
${ }^{13}$ Learners themselves, for instance, are very quick to identify lexical problems as their greatest single source of difficulty in the L2, and this self-assessment is borne out by the fact that large collections of errors - such as the Utrecht corpus - consistently show lexical errors outnumbering grammatical errors by three or four to one.
} 
habilidades básicas envolvidas no ato de comunicar (ouvir, falar, ler e escrever). Consequentemente, parece-nos claro que um conhecimento defasado de vocabulário, tanto em quantidade quanto em profundidade, tende a acarretar uma performance insatisfatória em LE.

Portanto, relegar a aprendizagem de vocabulário à ação do tempo, eximindo aprendiz/professor da responsabilidade de um ensino-aprendizagem sistematizado, mostra-se uma escolha pedagógica insuficiente.

O reconhecimento do léxico impulsionou pesquisas na área de ensino-aprendizagem de vocabulário, tanto em LE quanto em LM. Questões referentes às esferas teórica, didáticometodológica, cognitiva e de avaliação trouxeram à tona diversas discussões na tentativa de alcançar caminhos mais eficazes e suaves para a aprendizagem do léxico (SCARAMUCCI, 1995).

$\mathrm{Na}$ seção seguinte, trataremos a primeira questão que se coloca em qualquer discussão relacionada ao ensino-aprendizagem de léxico em LE: a definição de palavra.

\subsubsection{O que é uma palavra?}

O tema desta pesquisa é ensino-aprendizagem de léxico em LE, mais especificamente, em LJ. As palavras são o mote central de nosso estudo, por isso nossa primeira preocupação será apresentar algumas definições desse termo presentes na literatura da área de ensino-aprendizagem.

Segundo Nation (2013), se há a disposição de estudar/ensinar o léxico de uma LE de maneira sistemática, de início faz-se necessário determinar quantas palavras existem nela, quantas dessas palavras um nativo domina e quantas/quais dessas palavras temos que saber para nos comunicarmos na língua-alvo. Além disso, essas informações também podem atuar como norte para a elaboração de avaliações da extensão do vocabulário do aprendiz e para a definição do conteúdo programático de cursos.

No entanto, para contabilizar as palavras de uma língua, antes de tudo, é preciso ter clara a resposta da pergunta acima proposta: O que é uma palavra? Essa parece ser uma indagação aparentemente irrelevante, de resposta óbvia. Entretanto, respondê-la, após uma breve reflexão, revela-se uma tarefa complexa. Como afirma Biderman (2001, p.169) "as palavras são entidades abstratas que compõem o sistema linguístico”, são de difícil definição em virtude dos limites não estanques de seus aspectos formais, de conteúdo e expressão. Para 
Biderman (2001, p.169), os termos palavra e vocábulo usualmente empregados na designação dessa entidade abstrata são imprecisos e provocam equívocos.

A fim de determinar a unidade básica do léxico de maneira mais precisa, uma série de termos foram cunhados pelos estudiosos da linguagem para designar o que vulgarmente se entende como palavra, tais como lema, lexema, palavra léxica, palavra semântica, palavra derivada, palavra composta, sintagmema, sintagma, sintagma fixo, expressão idiomática, morfema, morfema livre e morfema preso, entrada lexical, item lexical, lexema, monema, semema, etc. Essa abundância de denominações é consequência da natureza multifacetada das palavras que permite análises de distintas perspectivas (VILELA, 1979, p.15). Na Lexicologia, o termo utilizado para designar a unidade de base do léxico é unidade lexical. Vemos que não há uma definição única e consensual de palavra, de modo que ao trabalharmos com o léxico, faz-se necessário esclarecer qual adotaremos. Esta pesquisa não se encontra inserida diretamente na área da Linguística ou Lexicologia, por isso, antes de nos colocarmos, discutiremos a seguir alguns posicionamentos de autores da área de ensino-aprendizagem de LEs, que consideram a problemática da definição de palavra dentro da perspectiva dessa área de estudo.

De um ponto de vista puramente formal, Bloomfield (1926) define palavra como uma forma livre mínima que ocorre de maneira isolada, constitui por si só um enunciado e não é passível de subdivisão em formas livres.

Ao pensarmos no conceito de palavra tendo em mente as demandas da área de ensino de LE, tal definição, puramente linguística-estrutural, não parece ser suficiente. Alguns autores se dispuseram a discutir a questão e apontaram se tratar de algo que não é passível de ser resolvido com uma conceituação breve e pontual. Esse fato foi claramente percebido por pesquisadores, que ao executarem a tarefa de contar as palavras de uma LE (CLAIBORNE, 1983; CRYSTAL, 1988; NATION, 2013), viram-se diante da dificuldade de determinar o que deve ser considerado como palavra.

Boni (2003, p.20) afirma que pesquisas que se empenharam em determinar a extensão do léxico de falantes nativos de língua inglesa apresentam resultados com números discrepantes entre si, devido às diferentes formas de definição de palavra aplicadas nos estudos. Gattolin corrobora tais ideias (2005, p.24) ao afirmar que as definições presentes na literatura são provenientes de pesquisas com objetivos distintos e que se alinham aos propósitos de cada estudo, ou à visão de linguagem dos próprios pesquisadores. 
Em pesquisas que envolvem o uso de computadores para a elaboração de corpus ou listas de palavras, encontramos duas definições que consideram unicamente a forma das unidades lexicais. Carrol, Vies, Richman (1971, apud SCARAMUCCI, 1995, p. 72) ${ }^{\text {i } 14}$ as tratam como vocábulos, logo, todos os itens que se apresentem com um espaçamento em branco antes e depois de seu registro são contados (tokens). Já Scott (1990) considera a palavra como uma entidade e conta individualmente qualquer manifestação que apresente diferenças na grafia (types). Tomemos como exemplo a frase em japonês "Watashi ga katta manshon wa furui manshon desu"15 . De acordo com o proposto por Carrol et al., essa frase é constituída por oito palavras, ao passo que para Scott há sete, já que a ocorrência dupla do item manshon deve ser contabilizada uma única vez.

No caso da LJ, a aplicação da forma de contagem proposta por Scott exige reflexão e cuidado, visto que é possível ocorrer a computação de uma mesma palavra repetidamente, em decorrência do sistema de escrita da língua que permite grafar as palavras de formas diferentes, como por exemplo 「きょう」 e「今日」. Nesse caso, as duas palavras significam hoje e são igualmente pronunciadas $k y \hat{o}$, mas por apresentarem registros gráficos distintos, de acordo com as regras de Scott (1990), devem ser contadas como duas palavras.

Outros autores propõem definições para palavra que levam em conta o significado, e não só a forma das unidades, sendo essas as mais relevantes para a área de ensinoaprendizagem do léxico.

Leech (1981) considera que a palavra tem dois significados diferentes: um conceitual, que se refere ao objeto, e um conotativo de caráter indeterminado e aberto.

Nation $(2013$, p.10) propõe considerar as palavras como lemas, que são compostos por uma palavra-base e suas formas flexionadas e reduzidas. Com isso, defende que o aprendiz deve se preocupar com o conceito subjacente a cada lema, o que leva a uma redução no número de palavras a serem aprendidas. Além disso, a aprendizagem de palavras que compõem um lema é facilitada diante da possibilidade de o aprendiz se apoiar em traços de familiaridade decorrentes de uma aprendizagem prévia, pois se tratam de palavras que não são completamente novas. Ou seja, o esforço depreendido para a aprendizagem, denominado sobrecarga da aprendizagem (learning burden), é amenizado. Ao utilizarmos o lema como unidade de contagem, temos uma redução significativa no número de palavras de um determinado corpus (SINCLAIR, 1991). Contudo, Nation (2013, p.11) coloca dois problemas

\footnotetext{
${ }^{14}$ CARROLL, J.B.; VIES, P.D.; RICHMAN, B. The American heritage word frequency book. New York: Houghton Mifflin, 1971.

15 "O apartamento que eu comprei é um apartamento velho".
} 
com relação à formação dos lemas: como proceder com formas irregulares e como determinar qual é a palavra-base.

Laufer (1997) considera que a melhor unidade para se contar as palavras é a de família de palavra. Para a autora, uma família de palavra compreende uma palavra-base e suas palavras flexionadas e derivadas, todas fortemente relacionadas. Isto é, palavras que tenham a mesma forma, mas carregam mais de um significado, como por exemplo, as palavras takai em takai biru (prédio alto) e takai hon (livro caro) devem ser contadas individualmente e alocadas em famílias diferentes por apresentarem significados distintos. Já as expressões idiomáticas, tais como ki o tsukeru (ter cuidado), embora contenham mais de uma unidade lexical, devem ser consideradas apenas como uma por expressarem um único significado. O mesmo se aplica as formas flexionadas, tais como kau (comprar), kawanai (não comprar), katta (comprei) e as derivadas de uma mesma unidade de sentido - takai (alto), takasa (altura) e takaku (altamente).

As definições mencionadas acima surgiram do propósito de estabelecer unidades para a contagem das palavras de uma língua-alvo. Alguns autores levam em conta apenas a forma da palavra, contabilizando cada item a partir das diferenças estruturais. Outros tomam como base o significado subjacente a cada palavra, agrupando-as em lemas ou em famílias de palavras, unidades compostas por um número plural de unidades lexicais que compartilham um conceito em comum.

Embora os objetivos dos trabalhos voltados à quantificação do léxico de LEs sejam, em grande parte, de cunho pedagógico (para a avaliação, para elaboração de syllabus, para elaboração de corpus, etc.), as considerações expostas acima não têm a pretensão de colaborar com a área de ensino-aprendizagem do léxico do ponto de vista didático-metodológico.

A AL (LEWIS, 1993), contributo teórico central desta pesquisa, apresenta uma proposta de classificação das palavras do léxico que pode influenciar diretamente o modo de ensinar vocabulário do professor de LE. Na AL, a unidade básica do léxico são os itens lexicais, definidos por Lewis (1993, p. 90 - tradução nossa) da seguinte maneira: “Os itens lexicais, então, são unidades independentes socialmente sancionadas. Muitos são palavras, mas muitos consistem em uma unidade de multipalavras". ${ }^{16}$

Dessa forma, para o autor, os itens lexicais podem ser palavras ou multipalavras. O primeiro tipo corresponde ao item lexical mais básico, são aqueles que podem ser empregados isoladamente e, se substituídos em um enunciado, causam mudança total de sentido.

\footnotetext{
${ }^{16}$ Lexical items, then, are socially sanctioned independent units. Many are words, but many consist of multi-word units.
} 
Conforme seu grau de informação, podem ser classificados como mais lexicalizados ou mais gramaticalizados (LEWIS, 1993, p.91).

O segundo tipo refere-se aos itens lexicais formados por mais de uma palavra, os quais se ramificam em:

- Polipalavras: itens lexicais formados por duas palavras; são consagrados pelo uso e, quase sempre, já dicionarizados.

- Colocações: diz respeito aos itens lexicais com alto grau de coocorrência; podem ser fixas ou livres.

- Expressões institucionalizadas: frases completas, ou parcialmente fixas, usadas com frequência para determinados propósitos, ou seja, são de natureza pragmática.

Na subseção 2.2.2 discorreremos com mais detalhes sobre a AL em si e sua concepção de léxico; e na subseção 2.2.3 sobre o léxico da LJ à luz das proposições dessa abordagem.

Diante do exposto, nesta pesquisa, entendemos palavra conforme o proposto pela AL, ou seja, como item lexical que pode ser simples (palavras) ou composto (multipalavras). Quando estivermos nos referindo aos itens do léxico de uma língua de forma mais geral, usaremos os termos palavra e unidade lexical, ao passo que empregaremos o termo item lexical quando a intenção for se referir às palavras dentro da perspectiva da AL.

\subsubsection{O léxico da língua japonesa}

A LJ compõe o quadro de elementos que formam o objeto desta pesquisa. Precisamente, propomos questões relacionadas ao ensino do vocabulário dessa língua. À vista disso, consideramos relevante discorrer sobre algumas características gerais do léxico da LJ, antes de prosseguirmos para as discussões sobre o ensino do mesmo.

O léxico da LJ, assim como o de qualquer outra língua, pode ser analisado a partir de diversas perspectivas, mas nesse momento nos ateremos aos seus aspectos mais particulares a fim de prover um quadro geral das propriedades desse léxico. Mais adiante, veremos que as palavras carregam um pacote de informações volumoso e quanto mais descobrimos sobre elas, mais dominamos a sua forma, o seu significado e o seu uso. Diante disso, parece-nos indispensável abordarmos, em especial, as características da LJ que não possuem correspondência na LP, visando entender como essas podem influenciar o processo de 
aprendizagem do léxico, seja do ponto de vista do ensino ou da aprendizagem. Consideramos importantes, para as discussões posteriores, o entendimento dos seguintes pontos: a forma (escrita e oral) das palavras, a formação das palavras e as peculiaridades do léxico da LJ.

\section{O sistema de escrita da língua japonesa}

As palavras ganham forma ao serem faladas ou grafadas, isto é, todas as línguas naturais, com exceção das línguas de sinais, possuem um sistema fonético e, quase todas, um sistema de escrita, doravante $\mathrm{SF}$ e $\mathrm{SE}^{17}$, que organizam as vias de expressão e acesso ao pensamento. Sendo assim, qualquer discussão que gire em torno do léxico, seja qual for a perspectiva, precisa ser fomentada também com o conhecimento mínimo desses dois aspectos da língua-alvo.

O SE da LJ é composto por três sistemas gráficos denominados kanji, hiragana e katakana. O primeiro é uma escrita ideográfica, cada caractere ou signo representa uma ideia ou conceito; já os outros dois são fonogramas silábicos, pois, diferente da LP, são representações de sílabas e não de fonemas. As letras romanas também são utilizadas, em escala bem menor, para grafar abreviaturas (CD, PC, AM), unidades de medida $\left(\mathrm{cm}, \mathrm{kg}, \mathrm{m}^{2}\right)$, transcrição de placas (nomes das estações de trem, lojas, ponto de informação), entre outros casos (FUKASAWA; GIROUX; SUZUKI, Tae; SUZUKI, Teiiti, 2001, p.17).

Todos os sistemas gráficos da LJ se originaram dos ideogramas chineses ${ }^{18}$. Esses surgiram inicialmente como pictogramas por volta do ano 2.500 A.C., os quais evoluíram até as formas gráficas hoje em uso. Cada ideograma pictográfico corresponde a uma ideia, conceito ou pode ainda ser o resultado da combinação de duas ou mais ideias, como em

$\ulcorner 日\lrcorner(h i-\mathrm{sol})+\ulcorner$ 月」(tsuki-lua) $=\ulcorner$ 明」 (akarui - claro $)$. No entanto, o número de ideogramas pictográficos é pequeno, sendo mais comum caracteres resultantes da combinação do elemento semântico de um e do elemento fonético de outro, como no exemplo do caractere $\ulcorner$ 梅」(ume - ameixeira) formado pelo ideograma $\ulcorner$ 木 $(k i$ - árvore $)$, responsável pela semântica, e o ideograma $\ulcorner$ 毎」 (bai), que determina apenas a leitura fonética de origem chinesa (FUKASAWA et al, 2001, p.17).

\footnotetext{
${ }^{17}$ Cook e Bassetti (2005, p. 4) definem sistema de escrita como as formas dos símbolos escritos de uma língua ou as regras para escrita de uma língua.

${ }^{18}$ Além dos ideogramas de origem chinesa, existe um pequeno número de caracteres que foram criados no Japão denominados kokuji.
} 
O registro mais antigo de uso dos ideogramas chineses como símbolo gráfico no Japão é de meados do século V. Entretanto, estima-se que foram introduzidos bem antes, durante o período Han (III A.C. - III D.C.) e percorreram um longo caminho de adaptação até serem completamente absorvidos pela LJ. No início, os primeiros textos escritos no Japão, denominados $\mathrm{kanbun}^{19}$, foram elaborados em chinês por nobres japoneses que aprenderam a língua chinesa. Com o passar do tempo, esses textos começaram a ser traduzidos para o japonês, dando origem ao estilo chamado kanbunkundoku ${ }^{20}$. Devido ao aspecto duplo dos caracteres chineses (fonético e semântico), a aplicação desses na escrita de textos com a estrutura sintática da LJ levou ao surgimento de formas diferentes de uso e leitura das da língua chinesa. $\mathrm{O}$ resultado são os ideogramas vigentes, chamados $k a n j i^{21}$, que possuem uma leitura chinesa (ondoku) e uma leitura japonesa (kundoku), podendo haver caracteres com apenas uma das formas de leitura, assim como caracteres com mais de duas leituras (FUKASAWA et al., 2001, p.18).

A leitura japonesa corresponde à leitura do kanji pelo significado, ou seja, após determinar o conceito expresso pelo caractere, passou a lhe atribuir como mais uma leitura a palavra correspondente em japonês. Por exemplo, o caractere $「 人 」$ significa "ser humano" em chinês, logo, em japonês, será lido como hito. Cada caractere é adaptado à palavra japonesa de igual significado. A leitura chinesa é a pronúncia chinesa dos kanji adaptada à fonética japonesa, não leva em consideração o aspecto semântico do kanji, apenas indica o modo como o ideograma deve ser lido (FUKASAWA et al., 2001, p.18). Como dito anteriormente, os kanji, em sua grande maioria, apresentam ao menos uma leitura japonesa, usada quando esse aparece isolado (男- otoko/ homem, 女- onnal mulher, 山 - yamal montanha), e uma leitura chinesa, empregada em palavras compostas por dois ou mais kanji (男性 - dansei/ masculino, 女性 - josei/ feminino 、火山-kazan/ vulcão).

Após a consagração do kanji como sistema de escrita da LJ, outros dois sistemas gráficos surgiram: o hiragana e o katakana, ambos derivados dos kanji. Enquanto os ideogramas representam ideias ou conceitos, os novos sistemas representam sons, especificamente sílabas, configurando-se em sistemas fonogramáticos silábicos.

Em meados do século VIII- IX, as mulheres da nobreza passaram a praticar o estilo cursivo da caligrafia, o qual foi aprimorado e estilizado ao ponto de originar, por volta do século XI, os símbolos do hiragana. Já o katakana teve um processo de criação diferente,

\footnotetext{
${ }^{19}$ Kan é o nome dado à China pelos japoneses no século III A.C. e bun significa texto.

${ }^{20}$ Significa "leitura de textos chineses em japonês".

${ }^{21}$ Grafia de kan.
} 
surgiu de abreviações dos kanji feitas pelos bonzos em suas anotações de estudo sobre os sutras escritos em chinês. Por fim, o kanji, o hiragana e o katakana passaram a ser usados simultaneamente. Ademais, existiam muitas formas em hiragana e katakana para representar um mesmo som, visto que as simplificações e abreviações eram frutos de kanji distintos (FUKASAWA et al., 2001, p.20).

Em 1900, finalmente ocorre a uniformização dos caracteres fonográficos, por meio de um decreto que delimitou 46 caracteres, respectivamente, para o hiragana e o katakana. Por representarem sílabas, são comumente chamados de silabários e organizados em colunas horizontais, chamadas dan, e colunas verticais, chamadas gyô:

Quadro 1 - Gojûon Hiragana e Katakana ${ }^{22}$

\begin{tabular}{|c|c|c|c|c|c|c|c|c|c|c|c|}
\hline $\begin{array}{l}\text { WA } \\
\text { gyô }\end{array}$ & $\begin{array}{l}\text { RA } \\
g y \hat{o}\end{array}$ & $\begin{array}{l}\text { YA } \\
g y \hat{o}\end{array}$ & $\begin{array}{l}\text { MA } \\
g y \hat{o}\end{array}$ & $\begin{array}{l}\text { HA } \\
g y \hat{o}\end{array}$ & $\begin{array}{l}\text { NA } \\
\text { gyô }\end{array}$ & $\begin{array}{l}\text { TA } \\
g y \hat{o}\end{array}$ & $\begin{array}{l}\text { SA } \\
g y \hat{\delta}\end{array}$ & $\begin{array}{l}\text { KA } \\
g y \hat{o}\end{array}$ & $\begin{array}{c}\mathrm{A} \\
g y \hat{o}\end{array}$ & & \\
\hline わ & $\dot{b}$ & & 1 & $1+$ & 2 & $t=$ & \pm & क & क & & $A$ \\
\hline$\nabla$ wa & $\overline{r a}$ & t ya & $\nabla \mathrm{ma}$ & 八 ha & + na & 夕 ta & \# sa & 力 $\mathrm{ka}$ & 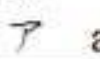 & & \\
\hline & $\begin{array}{ll}\text { I) } & \\
\text { 1) } \mathrm{ri}\end{array}$ & & $\begin{array}{l}2 x \\
\vdots \mathrm{mi}\end{array}$ & $\begin{array}{l}u \\
\leftarrow \text { hi }\end{array}$ & $\begin{array}{l}k \\
=n\end{array}$ & $\begin{array}{l}5 \\
f_{\text {chi }}\end{array}$ & $\begin{array}{l}\text { L } \\
\text { シ shi }\end{array}$ & $\begin{array}{l}\neq \\
\neq \mathrm{ki}\end{array}$ & $\begin{array}{l}1 \\
1\end{array}$ & & $\begin{array}{c}\text { I } \\
\text { dan }\end{array}$ \\
\hline $\begin{array}{l}\text { を } \\
\Rightarrow 0\end{array}$ & $\begin{array}{l}る \\
1 \mathrm{ru}\end{array}$ & $1 \mathrm{yu}$ & $\angle \mathrm{mu}$ & $\begin{array}{l}j . \\
>\mathrm{fu}\end{array}$ & $\begin{array}{l}\infty \\
7 \mathrm{nu}\end{array}$ & $\begin{array}{l}\supset \\
y \text { tsu }\end{array}$ & $\begin{array}{l}\frac{1}{9} \\
7 \mathrm{su}\end{array}$ & $\begin{array}{l}< \\
7 \mathrm{ku}\end{array}$ & $\begin{array}{l}j \\
7\end{array}$ & $\mathrm{u}$ & $\begin{array}{c}\mathbf{U} \\
\text { dan }\end{array}$ \\
\hline & $\begin{array}{ll}x & \\
\nu & \text { re }\end{array}$ & & \& me & $\widehat{\wedge}$ he & $\begin{array}{l}\text { 12 } \\
\text { 衣 ne }\end{array}$ & $\begin{array}{l}\tau \\
\text { 于 te }\end{array}$ & $\begin{array}{l}t \\
t \text { se }\end{array}$ & $\begin{array}{l}\text { H } \\
\text { 广 ke }\end{array}$ & & & $\begin{array}{c}\mathbf{E} \\
\text { dan }\end{array}$ \\
\hline $\begin{array}{ll}h & \\
\nu & \mathrm{n}\end{array}$ & $\begin{array}{l}3 \\
\square \text { ro }\end{array}$ & $\exists$ yo & $\begin{array}{l}t \\
t \mathrm{mo}\end{array}$ & $\begin{array}{l}\text { ほ } \\
\text { 木 ho }\end{array}$ & $\begin{array}{l}\text { の } \\
\angle \text { no }\end{array}$ & $\begin{array}{ll}\zeta & \\
r & \text { to }\end{array}$ & $\begin{array}{ll}z & \\
y & \text { so }\end{array}$ & $\begin{array}{l}\Xi \\
\beth \text { ko }\end{array}$ & $\begin{array}{l}\hbar \\
t\end{array}$ & 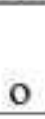 & $\begin{array}{c}\mathrm{O} \\
\text { dan }\end{array}$ \\
\hline
\end{tabular}

Tem-se ainda outras representações gráficas por meio de acréscimo de sinais aos fonogramas da tabela básica. Os sinais são: a) $\ulcorner\|\lrcorner-$ se acrescido à direita superior das formas gráficas pertencentes às colunas do KA, SA, TA e HA as transformam, respectivamente, em GA, ZA, DA e BA, as quais passam a ser designadas dakuon; b) $「 \circ\lrcorner-$ se acrescido à direita superior das formas gráficas pertencentes à coluna do HA, transformamnas em PA, as quais passam a ser designadas handakuon.

Por último, existem os sons contraídos representados pela junção de $\ulcorner や\lrcorner$ - ya, $\ulcorner ゆ\lrcorner-$ yu e $\ulcorner よ\lrcorner-$ yo, grafados em tamanho menor, posicionados abaixo dos fonogramas pertencentes a linha do I, a partir da coluna do K, constituindo uma única sílaba (FUKASAWA et al, 2001, p.26). Esses são chamados de yôon.

${ }^{22} \mathrm{O}$ quadro deve ser lido da direita para a esquerda e de cima para baixo, de acordo com a ordem da escrita em japonês. 
Quadro 2 - Handakuon e Dakuon

\begin{tabular}{|c|c|c|c|c|}
\hline $\begin{array}{l}\text { ぱ } \\
\text { パ pa }\end{array}$ & $\begin{array}{l}\text { ば } \\
\text { バ ba }\end{array}$ & $\begin{array}{l}\text { だ } \\
\text { ダ da }\end{array}$ & $\begin{array}{l}\text { ざ } \\
\text { ザ } \mathrm{za}\end{array}$ & $\begin{array}{l}\text { が } \\
\text { ガ ga }\end{array}$ \\
\hline ぴ & び & ぢ & じ & ぎ \\
\hline$ヒ^{0} \mathrm{pi}$ & ビ bi & ヂ $\mathrm{ji}$ & ジ ji & ギ gi \\
\hline ぷ & ぶ & づ & ず & ぐ \\
\hline$フ^{\circ} \mathrm{pu}$ & ブ bu & ヅ zu & ズ zu & グ $\mathrm{gu}$ \\
\hline ペ & & で & ぜ & げ \\
\hline ヘ pe & ベ be & デ de & ゼ ze & ゲ ge \\
\hline & & & ぞ & ご \\
\hline ポ po & ボ bo & ド do & ゾ zo & ゴ go \\
\hline
\end{tabular}

Quadro 3 - Yôon

\begin{tabular}{|c|c|c|c|c|c|c|c|c|c|c|}
\hline $\begin{array}{l}\text { り } \\
\text { リャ } \\
\text { rya }\end{array}$ & $\begin{array}{l}\mathcal{L}_{\alpha}+ \\
\vdots+ \\
\text { mya }\end{array}$ & 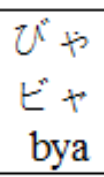 & $\begin{array}{l}U+ \\
匕+ \\
\text { hya }\end{array}$ & $\begin{array}{l}に+ \\
=+ \\
\text { nya }\end{array}$ & $\begin{array}{c}50+ \\
-7+ \\
\text { ja }\end{array}$ & $\begin{array}{l}\hbar+ \\
f+ \\
\text { cha }\end{array}$ & $\begin{array}{c}L_{+} \\
\forall+ \\
\text { ja }\end{array}$ & $\begin{array}{l}L+ \\
シ+ \\
\text { sha }\end{array}$ & $\begin{array}{l}\text { キャゃ } \\
\text { ギャ } \\
\text { gya }\end{array}$ & $\begin{array}{c}\ddagger \\
\neq \\
\text { kya }\end{array}$ \\
\hline $\begin{array}{l}\text { り巾 } \\
\text { リ } \\
\text { ryu }\end{array}$ & $\begin{array}{l}\mathcal{J}_{\alpha} \phi \\
\vdots=1 \\
\text { myu }\end{array}$ & $\begin{array}{l}\text { U゙ゅ } \\
\text { ビュ } \\
\text { byu }\end{array}$ & $\begin{array}{l}U_{D} \\
ヒ=1 \\
\text { hyu }\end{array}$ & $\begin{array}{l}\text { にD } \\
= \pm \\
\text { nyu }\end{array}$ & 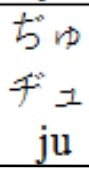 & $\begin{array}{l}\hbar \phi \\
f=1 \\
\text { chu }\end{array}$ & $\begin{array}{l}L^{*} \phi \\
\forall=1 \\
\mathrm{ju}\end{array}$ & $\begin{array}{l}L D \\
\dot{V}_{1} \\
\text { shu }\end{array}$ & $\begin{array}{l}\text { fャp } \\
\text { キ } 1 \\
\text { gyu }\end{array}$ & $\begin{array}{l}f D \\
\neq \neq \\
\text { kyu }\end{array}$ \\
\hline $\begin{array}{l}\text { り } 5 \\
\text { リ } \exists \\
\text { ryo }\end{array}$ & $\begin{array}{l}\mathcal{L}_{\alpha} \\
\vdots \\
\vdots \exists \\
\text { myo }\end{array}$ & $\begin{array}{l}\text { びょ } \\
ヒ ゙ ョ \\
\text { byo }\end{array}$ & $\begin{array}{l}\text { U } \\
ヒ \neq \\
\text { hyo }\end{array}$ & $\begin{array}{l}に よ \\
=\exists \\
\text { nyo }\end{array}$ & $\begin{array}{r}5 よ \\
x^{\prime} \equiv \\
\text { jo }\end{array}$ & 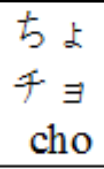 & $\begin{array}{l}L^{*} \\
\forall \neq \\
\text { jo }\end{array}$ & 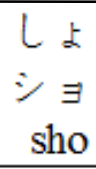 & $\begin{array}{l}\begin{array}{l}f \\
\pm\end{array} \\
\neq= \\
\text { gyo }\end{array}$ & 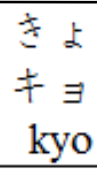 \\
\hline
\end{tabular}

Sobre a quantidade, o número de entradas nos dicionários de kanji varia entre 12.000 e 15.000 caracteres. No entanto, de acordo com a última lista atualizada em 2010, o governo japonês determinou 2.136 ideogramas para o uso diário, os quais são ensinados ao longo dos nove anos do ensino japonês obrigatório (BUNKACHÔ, 2010, p.1).

O uso concomitante dos sistemas de escrita permanece até hoje, mas atualmente é possível observar uma regularidade na aplicação de cada forma gráfica (FUKASAWA et al, 2001, p.20):

- Kanji: usado para grafar palavras ou parte de palavras que expressem ideias ou conceitos.

- Hiragana: usado para grafar elementos gramaticais da LJ e também partes flexionáveis de verbos e adjetivos.

- Katakana: usado para grafar palavras de origem estrangeira. 
Por fim, merece também uma menção à direção da escrita na LJ, que se mostra completamente oposta à ordem da LP. Enquanto nas línguas portuguesa, inglesa, francesa, entre outras, escrevemos na horizontal, da esquerda para a direita e com espaços entre as palavras, na LJ encontrarmos textos escritos também na vertical, da direita para a esquerda, sem espaçamento entre as palavras. A segmentação do enunciado escrito se dá pela intercalação dos sistemas de escrita, cada um com sua função, e não por espaços em branco.

\section{Aspectos da fonologia da língua japonesa}

Sobre o sistema fonológico da LJ, não abordaremos a questão a fundo, reservando-nos o direito de pontuar apenas os atributos mais relevantes para uma breve caracterização desse aspecto da língua em questão. Consideramos importante o tratamento dessa propriedade, ainda que timidamente, em razão da importância do conhecimento da forma oral das palavras, uma vez que esse atributo faz parte do pacote de informações que devemos saber sobre cada unidade lexical. Somado a isso, temos o fato da presença abundante de homônimos na LJ. No âmbito da escrita, as palavras podem ser homônimas quando grafadas em hiragana ou katakana, mas o problema se dissolve ao escrevermos cada palavra com seu respectivo kanji. No entanto, no âmbito da fala, os termos permanecem homônimos e a distinção se dá, muitas vezes, pela diferença na pronúncia.

A LJ padrão ${ }^{23}$ é constituída de cinco fonemas vocálicos e 16 fonemas consonantais. Esses fonemas, ao se combinarem, dão origem as unidades fonológicas mínimas chamadas moras, que podem apresentar as seguintes estruturas: vogal $(\mathrm{V})$, consoante + vogal $(\mathrm{CV})$, consoante $+\mathrm{y}+\operatorname{vogal}(\mathrm{CyV})$ e $\mathrm{M}^{24}$. As moras são graficamente representadas pelos sistemas de escrita hiragana e katakana (KOIZUMI, 1993, apud ITO, 2010, p.28). ${ }^{25}$

Quanto ao acento, trata-se de uma língua tonal, isto é, possui tons altos e baixos que se alternam na curva melódica do enunciado. Os tons altos são representados por $H$ e os tons baixos por $L$. Como regra do sistema de tonicidade da LJ, sempre haverá apenas um segmento

\footnotetext{
${ }^{23}$ O Japão possui muitos dialetos, mas se definiu como língua padrão a falada em Tóquio, para ser ensinada nas escolas e usada nos meios de comunicação.

${ }^{24} \mathrm{~V}, \mathrm{CV}$ e CyV são denominadas moras plenas. M representa as moras não-plenas /N/ (mora nasal), /Q/ (mora consonantal - refere-se ao pequeno tsu) e /R/ (mora longa). As moras não-plenas, assim como as moras plenas, são portadoras de um tom e de uma duração, embora apresentem diferenças em sua estrutura e na posição que ocupam dentro das palavras. (DOI, 1983, p.19).

${ }^{25}$ KOIZUMI, T. Nihongo kyôshino tameno gengogaku nyûmon. Tôkyô: Taisyûkan shoten, 1993.
} 
alto em uma palavra, visto que uma vez que haja manifestação de H não haverá mais mudança para L e retorno a H. Tomemos como exemplo a palavra hashi, composta por duas moras. $\mathrm{O}$ tom mais alto pode recair sobre o $h a$ ou sobre o shi. No primeiro caso, temos a configuração sonora da palavra hashi $「$ 箸」que significa “pauzinhos para comer”, já no segundo temos a configuração sonora da palavra hashi $「$ 橋」 que significa “ponte” (ITO, 2010, p.28). Vemos claramente que a tonicidade é importante para a distinção semântica das palavras na fala.

Outra característica que merece ser mencionada é o ritmo da LJ. Essa língua é segmentada em moras, as quais possuem tempo de duração igual e não apresentam intensidade interna, imprimindo um ritmo denominado moraico. Segundo Ito (2010, p.39):

\begin{abstract}
O número de moras determina o significado das palavras, temos que ler de acordo com a escrita em hiragana ou katakana, e também, manter a duração de cada mora equivalente às outras. Por exemplo, continuando com o exemplo da palavra obaasan, que significa avó, podemos dizer que possui cinco moras, porém, se omitirmos a segunda vogal "a" e pronunciarmos obasan como uma palavra que possui quatro moras, o sentido muda para "tia".
\end{abstract}

Ito (2010., p.38) nos dá outro exemplo ao apontar a unidade lexical きって (kitte selo), composta por três moras. Uma das moras é não-plena e sua representação se dá pelo fonograma \ulcorner\lrcorner$\lrcorner$ (tsu) grafado em tamanho menor, quando escrita em hiragana, ou pela duplicação de consoante, quando grafada em letras romanas. Na fala, esse tipo de mora especial deve ser sinalizada com uma pausa, de igual duração a uma mora plena, no momento da pronúncia. Caso não se respeite a quantidade de moras dessa palavra e ocorra a pronúncia きて (kite), a palavra proferida será “venha”.

Sendo assim, a manutenção do ritmo moraico na LJ é determinante para a construção de significado. Isso implica respeitar o número de moras de cada unidade lexical, dando-lhes a duração equivalente, independente de se tratar de uma mora plena ou não-plena.

\title{
Formação de palavras na língua japonesa
}

Segundo Ota (2011, p.79), a LJ é constituída por elementos lexicais de origem japonesa, chinesa e ocidental, as quais se ligam entre si $^{26}$ por meio de processos de formação de palavras distintos.

\footnotetext{
${ }^{26}$ Ota (2011, p.79) afirma que a junção geralmente ocorre entre elementos da mesma origem.
} 
Dentre as palavras da LJ existem as denominadas tanjungo, que apresentam unicamente um radical, e as gôseigo, palavras compostas que carregam mais de um radical ou radical + afixo $(\mathrm{s})$.

As palavras compostas são formadas a partir de três processos, sendo eles: a composição, a derivação e, em menor escala, a duplicação. Na base de qualquer palavra composta, independentemente do processo de formação, está uma unidade lexical autônoma, ou seja, uma palavra independente, que atuará como radical. Cada processo de formação dará origem a um tipo específico de palavra composta, os quais discutiremos caso a caso.

Conforme Ota (2011, p.80), o radical de uma palavra composta pode ser um substantivo, um radical de adjetivo, um junmeishi (um tipo de adjetivo), um verbo em forma ren'yô ou um advérbio.

As palavras compostas por derivação são denominadas haseigo e dizem respeito às unidades lexicais formadas a partir do acréscimo de um afixo (sufixo ou prefixo) à um radical, como em:

- $\quad$ Go $+k a z o k u=g o k a z o k u$ (sua família, família de outra pessoa).

- $\quad \boldsymbol{F u}+$ shizen = fushizen (não natural).

- Gakusei $+\boldsymbol{y} \hat{\boldsymbol{o}}=$ gakuseiyô (para uso de estudantes).

- $O m o+s a=o m o s a($ peso $)$.

Os dois primeiros exemplos são de derivação por prefixação. Segundo Kikuchi (2011a, p.105), os prefixos da LJ são divididos em dois grupos: os de tratamento (expressam respeito ou modéstia) e todos os demais (os que não carregam essa noção).

Sobre a derivação por sufixação, é interessante notar que o acréscimo do sufixo pode ou não dar origem a uma palavra de classe gramatical distinta a da palavra radical (KIKUCHI, 2011b, p.113). O terceiro exemplo mostra um caso de derivação por sufixação sem alteração de classe gramatical, visto que tanto a palavra derivada gakuseiyô (para uso de estudantes) quanto à palavra radical gakusei (estudante) são classificadas como substantivo. Já no quarto exemplo, o termo omosa (peso) é um substantivo derivado da palavra omoi (pesado) que é um adjetivo, ilustrando um caso de mudança de classe gramatical.

Ainda sobre as palavras derivadas, vale mencionar o processo de derivação regressiva, que se trata da transformação de um verbo em substantivo, ao se utilizar o verbo em sua forma ren'yô, como em hanasu (conversar) - hanashi (conversa), kaeru (voltar) - kaeri (volta) (OTA, 2011, p.80). 
Outro processo de formação de palavras é a composição, que dá origem aos chamados fukugôgo. Segundo Ota (2011, p.81), refere-se à união de duas ou mais unidades lexicais autônomas (radicais), de classes de palavras distintas ou não, sendo a classe da palavra derivada determinada pela última palavra presente na composição. A autora afirma que é expressivo o número de palavras na LJ oriundas desse processo de formação, as quais são recorrentes tanto na língua escrita quanto na falada.

As palavras compostas podem ser de diversas classes, mas as mais numerosas são os verbos compostos, os substantivos compostos e os adjetivos compostos.

Os verbos compostos podem ser formados pela junção dos seguintes radicais: verbo + verbo, substantivo + verbo e radical de adjetivo + verbo. O primeiro caso é o que apresenta maior ocorrência na LJ e é expresso da seguinte forma: [V1 (em forma de flexão ren'yô) + V2] ${ }^{27}$ (OTA, 2011, p.82). Esse tipo de verbo composto ainda sofre uma divisão interna em dois grupos conforme a relação semântica estabelecida entre os verbos da composição. Os do grupo I são caracterizados pela relação em que o V1 é semanticamente o principal e V2 apenas acrescenta uma informação (estado, aspecto ou modo como ocorre) sobre a ação expressa por V1. Como exemplos temos fuetsuzukeru (continuar aumentando), yomiowaru (terminar de ler), nakidasu (começar a chorar), entre outros. Nos do grupo II, a relação vista é de igualdade semântica, pois ambos preservam seu sentido original. Nesse caso, o verbo resultante expressa um significado construído a partir da junção da carga semântica dos dois radicais que constituem a palavra composta. Esse processo pode ser exemplificado por suberi $($ deslizar $)+$ ochiru $($ cair $)=$ suberiochiru $($ cair deslizando, escorregar $)($ OTA, 2011, p.82) .

O segundo tipo de verbo composto diz respeito à formação advinda da união de um substantivo + verbo. Segundo Ota (2011, p. 96), ocorre de duas maneiras:

- Substantivos que expressam semanticamente ações + o verbo suru (fazer), como em ryokô $($ viagem $)+$ suru $($ fazer $)=$ ryokôsuru $($ viajar $)$, shokuji $($ refeição $)+$ suru $($ fazer $)=$ shokujisuru (fazer uma refeição, comer).

- Substantivo + outros verbos, gerando compostos a partir da junção do sujeito ou complemento do verbo, tais como me (olho) + sameru (despertar) $=$ mezameru $($ despertar $) ; n a($ nome $)+$ tsukeru $($ colocar $)=$ nazukeru $($ dar nome $)$.

Por fim, o terceiro tipo de verbo composto é aquele formado pela união de um radical de adjetivo e um verbo. $\mathrm{O}$ radical do adjetivo corresponde à parte que antecede a desinência $-i$

\footnotetext{
${ }^{27}$ Palavra composta por dois verbos, onde o primeiro (V1) se apresenta sempre na forma flexionada ren' yô junto ao segundo verbo (V2).
} 
(como o kuro, de kuroi) $^{28}$. Sendo assim, temos como exemplo desse tipo de verbo composto a unidade lexical taka (alto) + naru (tocar, soar) = takanaru (soar alto) (OTA, 2011, p.96).

Vejamos agora os substantivos compostos. Ainda conforme Ota (2011., p.97), esses podem advir da junção de elementos nominais por natureza ou elementos deverbais, aqueles que se originaram de verbo pelo processo de derivação regressiva. Como exemplo, a autora cita:

- $\quad$ Natsu (verão) + yasumi (descanso, férias $)=$ natsuyasumi (férias de verão)

- $\quad N e($ preço $)+\operatorname{agari}($ subida $)=$ neagari $($ alta dos preços $)$.

- Kotoba (palavra) + tsukai (uso) = kotobazukai (emprego das palavras, linguajar).

Quando os elementos que compõem o substantivo composto carregam intrinsicamente uma relação sintática, a ordem de disposição dos elementos costuma respeitar a ordem sintática da LJ. As ordenações mais comuns são S1 (modificador) + S2 (modificado), S1 (sujeito) + S2 (elemento deverbal) e S1 (complemento) + S2 (elemento deverbal), como podemos ver nos exemplos de cada caso expostos respectivamente abaixo (2011., p.98):

- Denwa no bangô $\rightarrow$ denwa (elefone) + bangô (número) = denwabangô (número de telefone). Nota-se a ocorrência da supressão da partícula "no", mas a mesma permanece na interpretação da palavra. Além disso, os termos se apresentam em ordem inversa à ordem sintática da LP.

- $\quad$ Ame ga agaru $\rightarrow$ ame (chuva) + agari (parada)= ameagari (parada da chuva)

- Yama o aruku $\rightarrow$ yama (montanha) + aruki (caminhada) = yamaaruki (caminhada pela montanha).

Por fim, temos os adjetivos compostos. Diz respeito às palavras compostas que apresentam um adjetivo como último radical do composto. Assim como os substantivos compostos, havendo uma relação sintática entre os radicais, os mesmos são dispostos na ordem sintática da LJ. As combinações possíveis são substantivo + adjetivo, radical de adjetivo + adjetivo e verbo na forma de flexão ren'yô + adjetivo, sendo de ocorrência mais numerosa o primeiro tipo (TAMURA, 2006, p.13). Vejamos alguns exemplos:

${ }^{28}$ Kuro $=$ a cor preta; kuroi $=$ preto. 
- Substantivo + adjetivo.

Mimiatarashii $($ novidade $)=\operatorname{mimi}($ orelha $)+\operatorname{atarashii}($ novo $)$.

Shiokarai $($ salgado $)=$ shio $($ sal $)+$ karai $($ salgado $)$.

- Radical de adjetivo + adjetivo.

Amakarai $($ doce e ardido $)=$ amai $($ doce $)+$ karai $($ apimentado $)$.

Usugurai $($ meio escuro $)=$ usui $($ fraco, diluído $)+$ kurai $($ escuro $)$.

- Verbo na forma de flexão ren'yô + adjetivo.

Kangaebukai $($ sensato $)=$ kangaeru $\rightarrow$ kangae $($ pensamento $)+$ fukai (fundo, profundo)

Tabenikui $($ difícil de comer $)=$ taberu $\rightarrow$ tabe $($ comer $)+$ nikui $($ difícil de $)$.

Segundo Tamura (2006, p.15), além dessas combinações, há ainda, em número

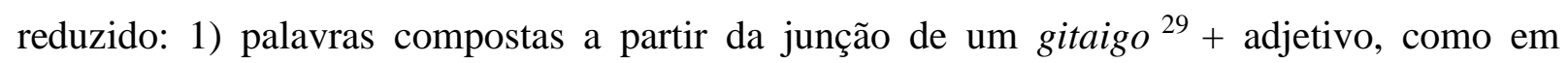
muzuтиzu + gayui = muzugayui (que faz comichão); 2) palavras formadas por um elemento adverbial que expressa ênfase + adjetivo, tal como tada + hiroi $=$ dadappiroi (demasiado espaçoso).

Além da derivação e da composição, a LJ apresenta outro mecanismo para a formação de palavras: a duplicação. De acordo com Tamamura (1998, p.10), o nome do processo é autoexplicativo, visto que se dá pela duplicação do primeiro radical como segundo elemento, formando os jôgo. Esses contêm traços semânticos que remetem à noção de plural, repetição ou ênfase. $\mathrm{O}$ elemento base de um jôgo pode ser de qualquer classe de palavra, imprimindo diversidade a esse tipo de composto. Abaixo temos exemplos das duplicações mais recorrentes:

- Duplicação de substantivo.

国々 ${ }^{30}$ (kuniguni - cada/todas as nações);

人々 (hitobito - as pessoas).

- Duplicação de pronome.

我々 (wareware-nós).

- Duplicação de verbos na forma ren'yô.

休み休み (yasumiyasumi - com pausa, pausadamente);

重ね重ね (kasanegazane - repetidamente).

${ }^{29}$ Espécie de onomatopeia que evoca um movimento ou uma qualidade física ou moral.

${ }^{30}$ É comum ao expressar a palavra na forma escrita em kanji colocar o símbolo 「々」 para indicar a repetição. 
- Duplicação de substantivo.

寒々 (samuzamu - desoladamente, friamente);

青々 (aoao - fresco/verdejante).

- Duplicação de advérbio.

まだまだ (madamada - ainda não);

わざわざ (wazawaza-de propósito, especialmente).

Quanto à classe das palavras geradas pela duplicação, essas podem ou não sofrer alteração com relação ao radical. As que sofrem alteração podem se manifestar em classes diferentes conforme o uso, como no caso de duplicação do substantivo iro (cor) que pode atuar como: junmeishi - iroiro na kuni (vários países); advérbio - iroiro to te o tsukusu (tentar de várias maneiras); substantivo - iroiro no hana (variedade de flores).

Embora o número de palavras com essa formação não seja superior ou equivalente ao dos outros processos de formação descritos acima, é significativa a quantidade de jôgo na LJ, configurando-se em umas de suas peculiaridades (TAMAMURA, p.10).

Observamos que os mecanismos de formação de palavras da LJ permitem um número expressivo de combinações, promovendo um léxico carregado de palavras compostas que muitas vezes geram dúvidas quanto ao seu significado e forma de uso. O conhecimento de como os itens lexicais da língua-alvo são formados pode auxiliar o aprendiz no entendimento de aspectos fonológicos, semânticos, gramaticais e pragmáticos que integram uma palavra e, até mesmo, a língua em estudo como um todo.

Todavia, a construção da palavra nem sempre se dá regida apenas por regras estruturais, resultando em uma aparente inconformidade interna de significado. Tamamura (1998, p.10) exemplifica ao citar a recorrente confusão gerada pelo termo kitsune udon. Trata-se de um prato da culinária japonesa composto por um tipo de macarrão imerso em um caldo com pedaços de tôfu frito, mas em seu nome há a palavra kitsune, que significa raposa. O aprendiz tende a ficar confuso ou a imaginar se no prato há carne de raposa, visto que outra versão dessa mesma iguaria, que leva carne, se chama niku udon (niku - carne), ou seja, o nome transmite o significado de forma transparente. No caso do kitsune udon, a construção do termo levou em consideração outro elemento além das regras formais. O prato recebeu esse nome por conter um ingrediente, o tôfu frito, que, segundo a crença popular, é apreciado por raposas. Sobre esse fenômeno, Tamamura diz ser "palavras nascidas do trabalho de juízo 
ou associações de ideias dos japoneses"31 (1998, p.10 - tradução nossa). Vemos que outros critérios também são empregados na formação das palavras da LJ, fato esse que exige atenção e cuidado ao se trabalhar com o vocabulário para evitarmos equívocos de interpretação.

Com isso, concluímos uma breve descrição dos processos de formação de palavras da LJ, os quais sumarizamos abaixo da seguinte forma:

\section{Figura 1: Formação das palavras na língua japonesa}

Tango
(palavra) $\left\{\begin{array}{c}\begin{array}{c}\text { Tanjungo } \\ \text { (palavra simples) } \\ \text { Goseigo } \\ \text { (palavra composta) }\end{array} \\ \text { Jôgo }\end{array}\right.$

\section{Peculiaridades do léxico da língua japonesa}

O Kokusai Kôrŷ̂ Kikin ${ }^{32}$ (2011) pontua em seu livro intitulado "Moji goi o oshieru"33 uma série de características do léxico da LJ que os aprendizes consideram peculiares, sendo elas: as palavras homônimas, as onomatopeias, as palavras de origem estrangeira, e as palavras que têm seu uso determinado por alguma circunstância (relação falante-ouvinte, situação, gênero etc.).

As palavras homônimas não são exclusividade da $\mathrm{LJ}$, mas causam desconforto aos aprendizes devido à quantidade existente. Assim como no português, os homônimos da LJ também se subdividem em homófonos (grafia diferente, mesmo som), homógrafos (mesma grafia, som diferente) e homônimos perfeitos (mesmo som e grafia, mas sentidos diferentes). Contudo, a incidência maior é de homófonos, com o agravante de que, diferente do português onde existem pares, no máximo trios, de palavras homófonas (como no caso de seção, sessão e secção), na LJ há grupos de palavras com o mesmo som, mas grafadas com ideogramas

\footnotetext{
31 日本人の見立て、連想が働いて生まれた語です。

32 Trata-se de uma organização vinculada ao Ministério das Relações Exteriores do Japão. Em português é denominada Fundação Japão e em inglês Japan Foundation. As publicações dessa organização são realizadas em várias línguas, razão pela qual as referências neste trabalho são feitas de acordo com a língua da publicação consultada.

33 "Ensinar letras e palavras".
} 
diferentes, como por exemplo 使用, 私用, 仕樣, 飼養, 試用, 枝葉 e 子葉 ${ }^{34}$. Todas essas unidades lexicais são pronunciadas shiyô, mas são grafadas com ideogramas diferentes e dotadas de significados distintos. Em textos, os ideogramas impedem eventuais equívocos de interpretação, pois permitem a identificação da palavra e seu significado mesmo que essa esteja isolada, fora de um contexto, já que os ideogramas representam conceitos e não apenas sons. No entanto, no discurso oral, a distinção é totalmente dependente do contexto, exigindo um grande esforço dos aprendizes (KOKUSAI KÔRYÛ KIKIN, 2011, p.63).

Quanto às onomatopeias, essas chamam a atenção pela sua abundância e ocorrência frequente na oralidade, em mangás, na escrita literária (prosa e poesia) e em outros meios. Segundo as entradas do Nihongo Onomatope Jiten ${ }^{35}$ (2007), existem 4,500 onomatopeias dicionarizadas na LJ. É um tipo de palavra que amplia a flexibilidade de expressão em japonês, sendo a habilidade de usá-las um dos indicativos do nível em que se encontra o aprendiz.

$\mathrm{Na}$ LP, as onomatopeias são definidas como palavras que tentam evocar determinados sons ou barulhos pelos seus fonemas. Já na LJ, as onomatopeias se subdividem, conforme o som que simulam, além de haver um tipo específico usado para representar estados físicos ou emocionais.

Segundo Luyten (2002, p.181), as onomatopeias similares às da LP recebem duas denominações em japonês: giongo $^{36}$ e giseigo ${ }^{37}$. A primeira se refere às onomatopeias que remetem a sons oriundos de seres inanimados (ame ga zaa zaa futteiru - está chovendo forte.). A segunda se refere às que reproduzem sons vindos da voz de humanos ou animais (inu ga wan wan to hoeru - o cachorro late).

O mencionado tipo particular de onomatopeia da LJ é chamado gitaigo ${ }^{38}$. Alcunhadas em português expressões situacionais ou mimésis, dizem respeito à representação de estados físicos, movimentos e fenômenos (LUYTEN, p.181). Como exemplo temos nuru nuru shiteiru (estar pegajoso), onde nuru nuru é uma mimésis do estado físico de algo/alguém que esteja pegajoso.

Quanto à formação dos giseigo/gitaigo, podemos ver claramente que essas são palavras compostas oriundas do mecanismo de formação da duplicação. Contudo, diante do

\footnotetext{
${ }^{34}$ Tradução das palavras: utilização, uso privado, maneira/meio, criação (de animais), experiência/teste, rama e cotilédone.

${ }^{35}$ Dicionário de Onomatopeias Japonesas.

${ }^{36}$ Giongo = palavra que reproduz ou imita som.

${ }^{37}$ Giseigo = palavra que reproduz voz.

${ }^{38}$ Gitaigo $=$ palavra que reproduz estado físico
} 
fato de que as onomatopeias são tentativas de representação de sons, podemos entender que o radical do composto não se trata de uma palavra independente, a qual recebeu algum acréscimo (afixo ou outro radical) ou foi duplicada, como ocorre nas demais palavras compostas da LJ.

Do ponto de vista gramatical, as onomatopeias são, em primeira instância, advérbios. No entanto, podem assumir diversas funções, de acordo com as partículas que as acompanham, como podemos ver nos seguintes exemplos de Tajima (2006, p.195):

- Verbo

Niko niko suru (sorrir).

Doki doki suru (palpitar o coração).

- Adjetivo

Kira kira no shizuku (gota brilhante) ${ }^{39}$.

Moja moja no kami (cabelo desgrenhado).

- Advérbio

Sura sura kaku (escrever sem dificuldades).

Suku suku sodatsu (crescer rápido).

- Substantivo

Doki doki ga hoshii (querer emoção).

Kori kori ga oishii (a crocância é gostosa).

As onomatopeias representam um desafio aos aprendizes de LP. A primeira dificuldade está na inexistência de onomatopeias do tipo gitaigo na língua materna. Ademais, as onomatopeias são palavras criadas a partir da percepção de um som ou de um estado, ou seja, estão condicionadas à interpretação dos falantes de uma língua e as possibilidades que a língua oferece para a representação. Como resultado, temos a onomatopeia para latido de cão expressa de formas diferentes em diversas línguas: $a u$-au (português), wan-wan (japonês), woof (inglês), etc.

Outra peculiaridade da LJ é a quantidade de estrangeirismos, em sua maioria, procedentes da língua inglesa. Essas palavras são grafadas com os caracteres do fonograma silábico katakana, marcando visualmente sua distinção. Geralmente, são escritas de maneira mais próxima possível do original, tendo como referência a forma oral da palavra e não a

\footnotetext{
${ }^{39}$ Refere-se à pingente em forma de gota.
} 
escrita. Segundo o Kokusai Kôryû Kikin (2011, p.63), os estudantes de LJ consideram difícil ler e escrever essas palavras. O motivo é fácil de se presumir, tendo em vista que se trata de uma terceira língua sendo pronunciada e escrita de acordo com as possibilidades fonéticas/morfológicas da LJ.

Além disso, há casos de palavras que são usadas com significado diferente ao da língua de origem, como por exemplo a unidade lexical sumâto, que em japonês significa "esbelto", mas em inglês, origem da palavra, significa "esperto" ou "inteligente"; e compostos lexicais que foram criados com palavras da língua inglesa, mas que não existem nela, tal como gas station que em japonês é gasorinsutando, levando o aprendiz a equívocos. Muitas das palavras emprestadas não possuem equivalentes na $\mathrm{LJ}$, mas existem também as palavras que têm uma versão emprestada e uma versão japonesa, tais como gyûnyû/ miruku (leite) e hayasa/ supîdo (velocidade), ocasionando dúvidas com relação a quando se usa uma ou outra.

Por último, outra característica do léxico da LJ considerada difícil pelos aprendizes é a existência de unidades lexicais que só podem ser usadas em determinadas situações, com determinadas pessoas, de acordo com a relação entre o falante e o ouvinte.

Além das variações linguísticas comuns a todas as línguas (vocabulário de uma determinada região, de jovens, de idosos, do local de trabalho etc.), existem na LJ também palavras usadas apenas por mulheres ou por homens, as palavras usadas só na escrita ou só na oralidade e as da linguagem formal. Em uma situação comunicativa, mesmo que o aprendiz saiba uma palavra que expresse o desejado, há ainda a necessidade de julgar se o termo é adequado à pessoa ou à circunstância. Isso não é exclusividade da $\mathrm{LJ}$, mas por questões culturais, esse tipo de erro tem um peso relevante (KOKUSAI KÔRYÛ KIKIN, 2011, p.64).

Em síntese, o léxico da LJ é composto por palavras de diversas origens, com predominância na japonesa e na chinesa e destaque para a quantidade substancial de itens lexicais de origem inglesa. O sistema de composição das palavras apresenta, além dos mecanismos de derivação e de composição, o da duplicação. Esse é particularmente interessante por dar origem às onomatopeias, que se subdividem em dois grupos: as que reproduzem sons (giseigo), presentes também na LP, e as que imitam estados físicos (gitaigo), inexistentes na LP. Além disso, é notável a frequência das onomatopeias na comunicação, em contraposição à LP, que restringe o uso a casos bem específicos.

O sistema de escrita é misto, composto por fonogramas (representam um som) e ideogramas (representam uma ideia, com mais de uma possibilidade de leitura). As formas gráficas, em comparação às formas das letras romanas, são complexas e para aprender a escrever é necessário iniciar do ponto zero: aprender a melhor maneira de segurar o lápis, a 
traçar os contornos e a ordem da escrita de cada item. Ademais, escreve-se na vertical e da direita para a esquerda, fato que exige um reaprender tanto na forma de escrever quanto na forma de ler.

Do ponto de vista fonológico, trata-se de uma língua tonal, segmentada em moras e com ritmo moraico. Embora a quantidade de fones da LJ seja pequena, alguns desses são inexistentes na LP, assim como alguns fones do português são inexistentes na LJ, mas a quantidade de fones comuns possibilita que a compreensão e produção da fala não sejam difíceis ao ponto de representar um obstáculo para a comunicação. Os fones são representados pelos símbolos gráficos de maneira clara, ou seja, uma vez aprendida o som que determinado fonograma representa não haverá mudança quando esse aparecer em uma palavra, sendo transparente a relação entre a forma escrita e a oral.

Por fim, nossa intenção com essa breve descrição sobre as palavras da LJ foi pontuar características que devem ser levadas em conta ao se trabalhar com o léxico dessa língua. Como veremos na seção a seguir, cada palavra carrega uma gama de informações que precisam ser dominadas para que haja o conhecimento integral de cada unidade lexical, a fim de garantir o desenvolvimento pleno da competência lexical do aprendiz e, consequentemente, da competência comunicativa.

\subsubsection{O que é saber uma palavra?}

Aqueles que estudam ou ensinam uma LE, ao se depararem com uma palavra em outro idioma, recorrem instintivamente ao dicionário em busca de uma tradução. $\mathrm{O}$ dicionário é a salvação para um momento pontual de dúvida, mas transmite a equivocada sensação de que aprender um item lexical em LE é encontrar um equivalente na LM.

Dentre os diversos aspectos que precisam ser desenvolvidos durante a aprendizagem de uma LE, a competência lexical é uma delas. No entanto, a própria literatura não fornece uma conceituação amplamente aceita do termo, fato decorrente do descaso com relação à necessidade de se considerar o que está implícito no conhecimento de uma palavra (JIANG, 2000).

Segundo Scaramucci (1997), definir competência lexical como o repertório de palavras que o aprendiz sabe o correspondente na língua-alvo é reducionista e leva em consideração apenas a extensão do vocabulário, ou seja, apenas o número de palavras conhecidas e não o quanto se sabe sobre essas palavras. Jiang (2000) complementa afirmando 
que não podemos confundir conhecimento lexical com competência lexical. O primeiro se refere à gama de informações sobre a palavra que o aprendiz armazenou em um sistema de memória geral; já o segundo diz respeito à habilidade de articular, selecionar e usar todos esses conhecimentos na comunicação, com ênfase na automaticidade no processamento lexical.

Vemos que para o desenvolvimento de uma competência lexical sólida é indispensável para a aprendizagem de novas unidades lexicais de uma maneira mais profunda, com o domínio do maior número possível de informações que essas podem carregar. Essa percepção traz à tona a necessidade de resposta a uma pergunta fundamental: Mas afinal, o que é saber uma palavra?

Como dito acima, essa questão foi pouco discutida pelos estudiosos da área até meados dos anos 70. O primeiro artigo de grande relevância sobre o assunto é de Jack Richards (SCARAMUCCI, 1995, p.78), intitulado "The role of vocabulary teaching", publicado em 1976. Nessa obra, Richards (1976, p.83 - tradução nossa) procura responder à pergunta aqui proposta, estabelecendo oito pressupostos do que significa saber uma palavra:

1. O falante nativo de uma língua continua a expandir seu vocabulário na idade adulta, o que, comparativamente, não acontece com a sintaxe.

2. Conhecer uma palavra significa conhecer o grau de probabilidade de encontrá-la na fala ou na escrita.

3. Conhecer uma palavra implica conhecer as limitações de uso de acordo com a variação de função e de situação.

4. Conhecer uma palavra implica conhecer o comportamento sintático associado a ela.

5. Conhecer uma palavra implica conhecer a forma subjacente dessa palavra e suas possíveis derivações.

6. Conhecer uma palavra implica conhecer a rede de associações entre ela e outras palavras da língua.

7. Conhecer uma palavra significa conhecer seu valor semântico.

8. Conhecer uma palavra significa conhecer diferentes significados associados a ela. ${ }^{40}$

40 1. The native speaker language continues to expand his vocabulary in adulthood, whereas there is comparatively little development of syntax in adult life.

2. Knowing a word means knowing the degree of probability of encountering that word in speech or print. For many words, we also know the sort of words most likely to be found associated with the word.

3. Knowing a word implies knowing the limitations imposed on the use of the word according to variations of function and situation.

4. Knowing a word means knowing the syntactic behaviour associated with that word.

5. Knowing a word entails knowledge of the underlying form of word and the derivatives that can be made from it.

6. Knowing a word entails knowledge of the network of associations between that word and the other words in language (sic.)

7. Knowing a word means knowing the semantic value of the word. 8. Knowing a word means knowing many of the different meanings associated with the word. 
No entanto, embora de grande valia, Meara (1996) afirma que o autor não conseguiu cumprir de maneira satisfatória a missão de determinar um modelo de conhecimento lexical, pois considera que Richards estava mais preocupado em aplicar as teorias linguísticas vigentes na época a um problema pedagógico, do que realmente estabelecer uma caracterização do conhecimento lexical.

Meara (1996, p.2), após uma análise mais detida dos pressupostos, identifica que o primeiro tem embasamento no trabalho de Chomsky (1969), o qual afirma que a criança domina a sintaxe de sua LM por volta dos sete anos de idade, mas o vocabulário continua a se expandir ao longo da vida; o segundo se apoia nas pesquisas sobre análise computacional para elaboração de corpora (KUCERA; FRANCIS, 1967); o terceiro relaciona-se com as novas preocupações que atraíam a atenção dos pesquisadores da área de linguística na época: a variação temporal, a variação geográfica, a variação social, o papel social, o campo do discurso e o modo de discurso; o quarto demonstra a preocupação de Richards com a curta duração da teoria da sintaxe que logo caiu em desuso; o quinto está ligado ao trabalho de Chomsky e Halle (1968) sobre a regularidade dos processos morfológicos da língua inglesa do ponto de vista fonológico; o sexto remete aos estudos cognitivos de Deese (1965) sobre o comportamento de associação entre as palavras; o sétimo pressuposto tem como base pesquisas sobre descrição de significados (OSGOOD; SUCI; TANNENBAUM, 1957); e, por fim, o último pressuposto parece ser o único que não apresenta relação com nenhuma teoria em evidência na época.

Uma vez que a preocupação de Richards não era essencialmente fornecer um modelo sistematizado do que implica saber uma palavra, mas sim uma tentativa de alinhar as pesquisas linguísticas à prática de ensino, é de se esperar que seus pressupostos, quando analisados do ponto de vista pedagógico, evidenciem muitas lacunas.

De acordo com Meara (1996, p.3), além do fato de a escolha dos oito pressupostos ter sido feita em conformidade com os temas linguísticos em alta, e não visando o problema da questão em si, o trabalho de Richards se revela desconectado com o objetivo principal também pela escolha da ordem de exposição dos pressupostos. Suposições muito mais relevantes estão elencadas nas posições finais de sua lista, como por exemplo, o item oito “conhecer diferentes significados associados a ela”, embora seja uma informação primária ao se aprender uma nova palavra.

Por fim, Meara (1996., p.3) critica também a total ausência de menção a problemas característicos da aprendizagem/aquisição de vocabulário, como por exemplo as condições em que as palavras são aprendidas/adquiridas e sobre o vocabulário receptivo e produtivo. 
Mesmo passível de críticas, o trabalho de Richards foi pioneiro e serviu como base para diversos estudos posteriores na área de ensino-aprendizagem do léxico (ELLIS, 1995; SCHIMITT; MEARA, 1997; SCHIMITT; MCCARTHY, 1997; entre outros). Ao agregar aspectos linguísticos, psicolinguísticos e sociolinguísticos ao inventário de conhecimentos das unidades lexicais, o autor deu origem ao conceito rico de vocabulário, estabelecendo uma visão qualitativa do léxico, preocupada não só com a quantidade, mas também com a profundidade do conhecimento lexical (SCARAMUCCI, 1997, p.2). As lacunas do trabalho de Richards mencionadas anteriormente foram discutidas posteriormente por diversos autores, visto que a questão permanecia em aberto.

Em busca de uma resposta, Nation $(1990,2013)$ ampliou os pressupostos de Richards e propôs uma nova categorização dos conhecimentos que constituem as palavras. Em um primeiro momento, determinou os aspectos fundamentais da palavra, sendo eles a forma, o significado e o uso. Posteriormente, realizou uma divisão interna em cada aspecto representando os níveis de conhecimento receptivo e produtivo, dando origem ao seguinte quadro:

\section{Quadro 4 - O que envolve saber uma palavra? ${ }^{41}$}

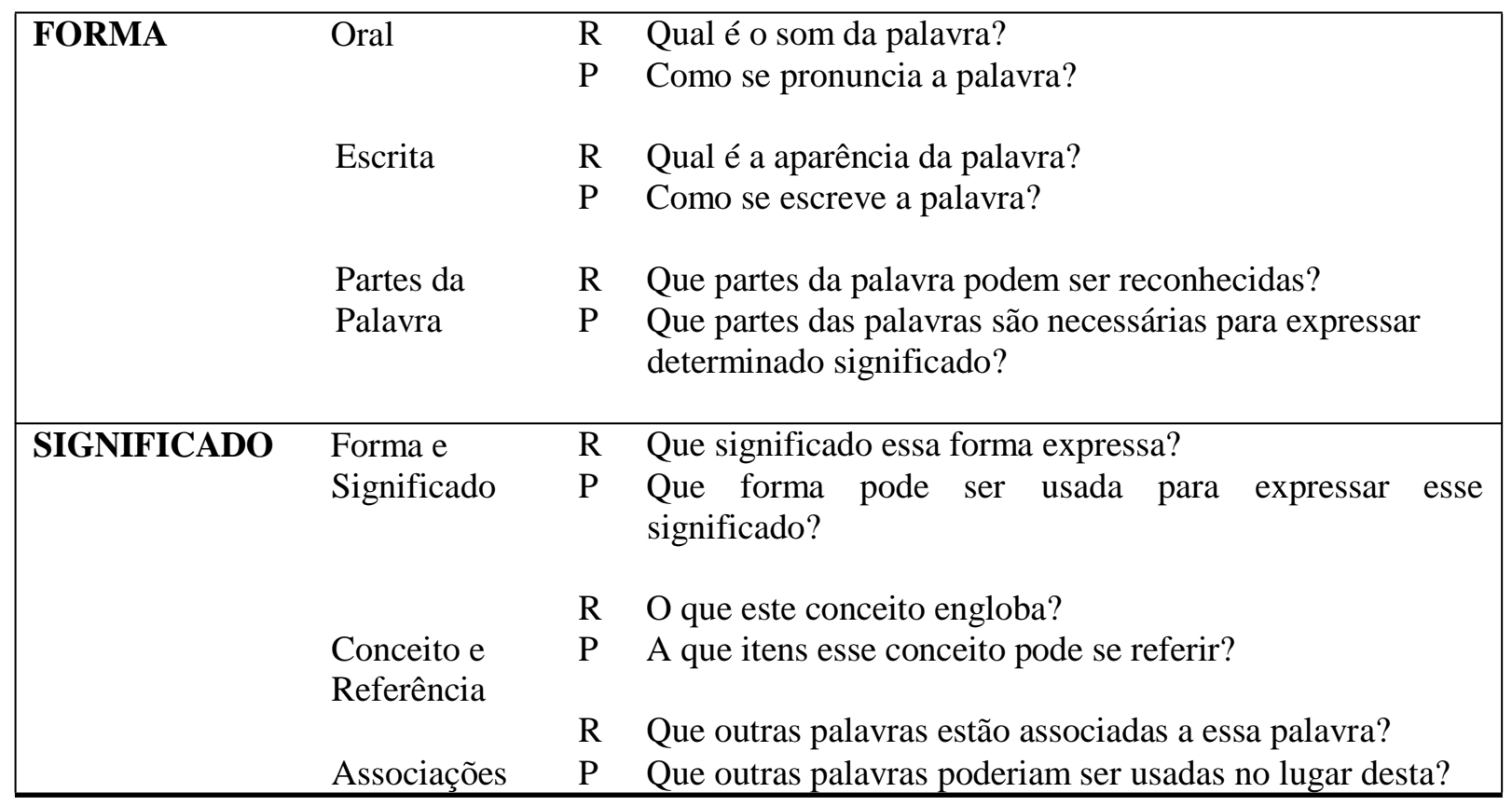

\footnotetext{
${ }^{41} \mathrm{Na}$ terceira coluna, $\mathrm{R}$ representa receptivo e $\mathrm{P}$ representa produtivo.
} 
Continuação do quadro 4 - O que envolve saber uma palavra

\begin{tabular}{|c|c|c|c|}
\hline \multirow[t]{3}{*}{ USO } & $\begin{array}{l}\text { Funções } \\
\text { Gramaticais }\end{array}$ & $\begin{array}{l}\mathrm{R} \\
\mathrm{P}\end{array}$ & $\begin{array}{l}\text { Como a palavra ocorre? } \\
\text { Como a palavra deve ser usada? }\end{array}$ \\
\hline & Colocações & $\begin{array}{l}\mathrm{R} \\
\mathrm{P}\end{array}$ & $\begin{array}{l}\text { Que tipo ou tipos de palavras podem acompanhar essa } \\
\text { palavra? } \\
\text { Que palavras ou tipos de palavras devem ser usadas para } \\
\text { acompanhar essa palavra? }\end{array}$ \\
\hline & $\begin{array}{l}\text { Limitações de } \\
\text { uso }\end{array}$ & $\mathrm{P}$ & $\begin{array}{l}\text { Quando, onde e com que frequência essa palavra é } \\
\text { encontrada? } \\
\text { Quando, como e com que frequência essa palavra pode ser } \\
\text { usada? }\end{array}$ \\
\hline
\end{tabular}

(NATION, 2013, p. 49 - tradução nossa) ${ }^{42}$

A forma diz respeito à fonologia, ortografia e morfologia das palavras; o significado se refere aos conceitos, a relação entre a forma e o significado e as possíveis associações que a palavra pode acionar; o uso está ligado às funções gramaticais, as colocações e ao uso adequado ou as limitações de uso. A consciência do que é exatamente necessário saber para o domínio de cada um dos aspectos de uma palavra pode auxiliar professores e aprendizes no processo de ensino-aprendizagem do léxico em LE.

Sobre a forma, em específico a oral, estudos indicam que a memória fonológica de curto prazo é um fator importante para a aprendizagem do léxico, evidenciando a importância de se buscar recursos que possam auxiliar no desenvolvimento da compreensão e produção oral das palavras. (GATHERCOLE; BADDELEY, 1989 apud NATION, 2013) ${ }^{43}$. Ainda sobre a forma, Nation (2013) faz uma observação relevante para a nossa pesquisa: a questão da “carga necessária para a aprendizagem" "44. Esse termo se refere à relação entre a proximidade das línguas envolvidas no processo de aprendizagem e o esforço que o aprendiz precisará empreender. Em outras palavras, quanto mais distante a língua-alvo for da língua materna, maior será a carga necessária para a aprendizagem. Nesse sentido, temos aqui uma forte justificativa para a emergência já mencionada de haver um ensino sistematizado do léxico, particularmente no caso do contexto de ensino desta pesquisa que envolve falantes de português aprendendo japonês, dada a clara distância existente entre as línguas.

\footnotetext{
${ }^{42}$ Versão original no Anexo A.

${ }^{43}$ Gathercole, S. E.; Baddeley, A. D. Evaluation of the role of phonological STM in the development of vocabulary in children: a longitudinal study. Journal of Memory and Language, 28, 200-213, 1989.

${ }^{44}$ Learning burden.
} 
O significado é o mais valorizado pelos aprendizes, pois diante de uma nova palavra, o primeiro esforço será sempre o de memorizar o sentido. A memória, mais uma vez, exerce uma intensa influência na capacidade do aprendiz de relacionar forma e significado, visto que a cada recuperação correta ocorre o reforço da ligação entre esses dois aspectos. Do ponto de vista pedagógico, essa informação traz à tona o dever do professor de assegurar momentos de recuperação e orientar os aprendizes sobre essa estratégia de aprendizagem. (NATION, 2013). Outro ponto relevante sobre o significado é a pluralidade de palavras que podem compartilhar um mesmo traço semântico. Esse fenômeno, comum a todas as línguas, é de fácil observação na LJ devido ao seu sistema de escrita. Por exemplo, a palavra 「長い」-nagai significa longo, comprido e seu ideograma é usado em diversas palavras que expressam alguma posição hierárquica superior dentro de uma organização, como em $\ulcorner$ 社長」 - shachô (presidente de empresa)、「校長」-kôchô (diretor de escola)、「会長」-kaichô (presidente de associação) etc. Com esse exemplo, podemos ver também que as palavras podem carregar um conceito implícito de base cultural. No Japão, pessoas que ocupam essas posições são aquelas que possuem experiência mais longa, geralmente são os mais velhos, e por isso o ideograma que representa a palavra "longo, comprido" é usado na formação dessas palavras. Já em inglês, a palavra head, que significa cabeça, é usada também para designar posição hierárquica superior, indicando que o conceito implícito é "aquilo que comanda ou pensa". O professor deve ficar atento às palavras que exigem um conhecimento cultural para ajudar seus aprendizes na compreensão dessas unidades lexicais. (NATION, 2013).

Um último item relacionado ao significado que merece atenção são as associações. Segundo Vermeer (2001), as palavras podem ser representadas como "nós em uma rede”, os quais se interconectam em diversas dimensões: temática, fonológica, morfológica, conceitual e sociolinguística. A profundidade do vocabulário está sujeita à densidade da rede que circunda as palavras. Além disso, essa rede também é determinada pela visão e a experiência pessoal de cada sujeito.

Anglin (1985 apud HEDGE, 2000, p.123) ${ }^{45}$, usa a palavra "cachorro" para exemplificar a complexidade do conhecimento lexical do ponto de vista das associações. Uma pessoa, ao pensar em "cachorro", pode lembrar de características mais gerais do animal, como as partes do corpo, as diferentes raças, os sons, até informações mais específicas, resultantes do tipo de relação que essa pessoa já teve com o animal. Pessoas que tenham tido alguma

\footnotetext{
${ }^{45}$ ANGLIN, J. M. The child's expressible knowledge of word concepts. In NELSON, K.E. (ed.). Children's language, New Jersey: Lawrence Erlbaum, v. 5. p. 77-127, 1985.
} 
experiência negativa com cachorro, como por exemplo uma mordida, podem agregar à rede semântica que rodeia essa palavra conceitos como violento, agressivo ou perigoso, os quais provavelmente não aparecem no esquema semântico de uma pessoa que só tenha tido experiências positivas com o animal.

A respeito do aspecto uso, Nation (2013) afirma se tratar do conhecimento de como uma palavra se comporta em uma frase, e para isso é preciso entender sua função gramatical. No entanto, o uso não é condicionado unicamente pelas regras gramaticas. Muitas vezes, um enunciado gramaticalmente correto é inadequado devido a uma combinação de palavras não usual na língua-alvo. Trata-se de uma questão de colocação da palavra. Por exemplo, a palavra sonhar em japonês é yume o miru, onde yume é "sonho" e miru é "ver". Provavelmente, se pedirmos a um aprendiz para dizer essa palavra em japonês, ele não irá oferecer a resposta correta. Orientado pelas regras da LJ, possivelmente dirá yumesuru, já que suru é usado para transformar substantivos em verbos. Caso use a LP como referência, "ter um sonho", responderá yume ga aru, que em japonês assumirá o sentido de ter um desejo, uma ambição e não o sentido de sonhar. As colocações são usos socialmente estabelecidos, muitas vezes sem uma explicação aparente e dependem do contexto em que surgem, por isso são comumente ensinadas como um único item lexical.

Quanto à adequabilidade e às limitações de uso, essas têm relação com a situação comunicativa. Uma palavra que pode ser usada em um determinado contexto, com uma determinada pessoa, pode não ser a melhor escolha para uma outra ocasião (NATION, 2013). Tomemos como exemplo a palavra taberu, que significa comer. Em japonês, ela pode ser usada para se referir à ação de uma pessoa próxima, hierarquicamente igual, mas não é adequada se estivermos falando sobre o ato de comer do chefe ou de outra pessoa de posição superior. Nesse caso, usa-se meshiagaru, que significa igualmente comer, mas de forma respeitosa.

Uma vez determinados os aspectos das palavras e os saberes que são exigidos para o domínio de cada um deles, Nation (2013) completa seu modelo introduzindo os níveis de conhecimento de vocabulário. Segundo o autor, todos os aspectos da palavra podem se manifestar em dois níveis de conhecimento: o receptivo e o produtivo. O primeiro diz respeito à habilidade de reconhecer uma palavra e associá-la a um significado quando lida ou falada. $\mathrm{O}$ segundo envolve o desejo de expressão de um significado por meio da fala ou da escrita, exigindo o resgate e a produção da forma oral ou escrita das palavras. Além dos aspectos e dos níveis de conhecimento, podemos ainda falar sobre a dimensão do vocabulário. A tarefa 
de avaliar o conhecimento lexical de um indivíduo pode ser executada a partir de três dimensões: a da extensão, a da profundidade e a da produtividade.

A extensão se refere à quantidade de palavras que o aprendiz conhece, ao passo que a profundidade diz respeito ao quanto o aprendiz sabe sobre essas palavras (NASSAJI, 2004; MEARA, 1996; READ, 2000).

A terceira dimensão, a da produtividade, diz respeito aos níveis de conhecimento receptivo (reconhecimento) e produtivo (uso) (LEFFA, 2000, p.32). Essa distinção é de suma relevância, uma vez que cada dimensão exige formas diferentes de avaliação do conhecimento de vocabulário. Um vocabulário extenso nem sempre é melhor do que um vocabulário com profundidade. Para fins comunicativos, saber aplicar uma única palavra em diversas situações, em decorrência de um conhecimento profundo, pode ser mais rentável do que saber várias palavras, mas não conseguir manipulá-las em diversos contextos (NATION, 2013).

O modelo de conhecimento lexical de Nation (2013) expõe claramente a complexidade do que é saber uma palavra. Podemos considerar impossível adquirir de uma única vez uma unidade lexical de forma integral, tampouco dominar todas as suas possíveis manifestações. Trata-se de um processo gradual que deve ser respeitado e alimentado tanto pelo professor quanto pelo aprendiz.

Por fim, consideramos respondida a pergunta posta no início dessa subseção. O modelo proposto por Nation (2013) norteará, em especial, a escolha dos critérios de correção das atividades e do teste de vocabulário que serão aplicados na etapa de coleta de dados.

Na subseção seguinte, trataremos de um último tema relevante para a caracterização do léxico: a quantidade de palavras que existem na $\mathrm{LJ}$ e quantas delas precisamos saber para nos comunicarmos de maneira efetiva.

\subsubsection{Quantas e quais palavras temos que saber?}

Nation (2013) afirma que, como já mencionado anteriormente, para estudar/ensinar o vocabulário de uma LE de maneira sistemática, é importante saber quantas palavras existem na língua-alvo, para se definir quantas dessas um nativo domina e, dentre essas, quantas/quais o aprendiz deve saber para se comunicar, como ilustrado na figura a seguir: 


\title{
Figura 2: Palavras-alvo no ensino-aprendizagem de LE
}

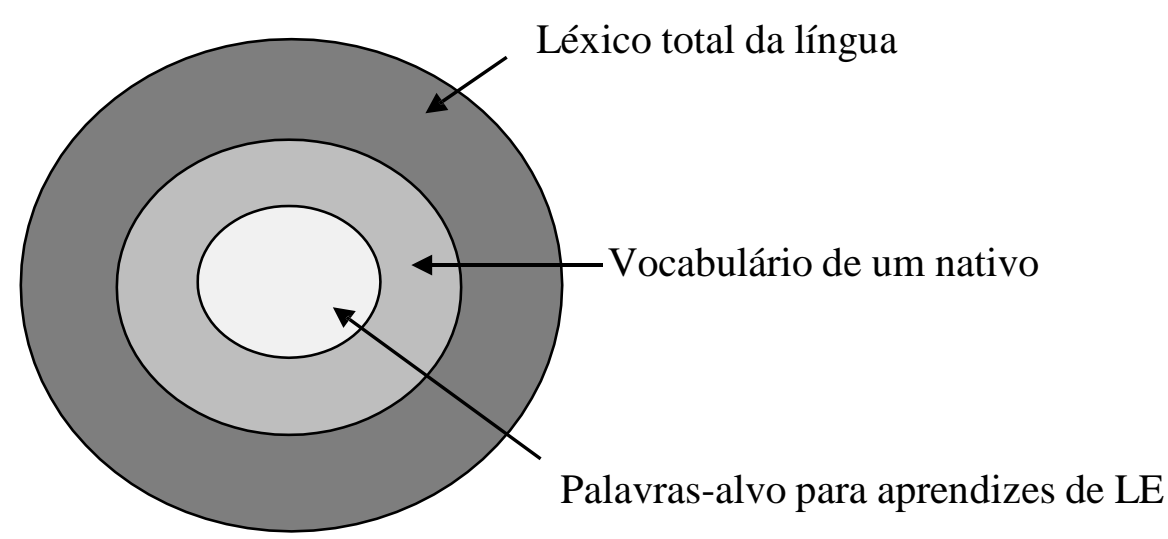

No entanto, determinar exatamente o número de palavras existentes em uma língua é uma tarefa aparentemente impossível. Em um dicionário geral podemos encontrar uma extensa amostra de unidades lexicais, mas nenhuma obra lexicográfica consegue abranger todas as que efetivamente compõem uma língua. Segundo Biderman:

\begin{abstract}
Os dicionários constituem uma organização sistemática do léxico, por meio da qual os lexicógrafos tentam descrever o vocabulário dessa língua acumulado ao longo dos séculos. Assim, essas obras recolhem o patrimônio léxico da língua num dado momento da história da comunidade, visando descrever e documentar esse tesouro lexical que a tradição foi armazenando. De fato, esse ideal é intangível, já que o léxico cresce em progressão geométrica e esse processo nunca cessa enquanto a língua for viva. (2006, p.36).
\end{abstract}

Mesmo com suas limitações, um bom dicionário geral de ampla extensão ainda pode ser considerado uma válida referência de quantas palavras existem aproximadamente em uma língua.

No caso da LJ, um dicionário de pequeno porte apresenta de 60.000 a 80.000 entradas. Já no maior dicionário disponível, podemos encontrar até 500.000 entradas $^{46}$, mas vale a ressalva de que dentre essas estão termos técnicos, unidades lexicais antigas (já em desuso), nomes próprios etc. (KOKUSAI KÔRYÛ KIKIN, 2011; KATSUDA, 2010).

Da mesma forma que não é possível quantificar exatamente as unidades lexicais de uma língua, também não é crível que um falante, mesmo um nativo, conheça todas as palavras de uma língua. Sendo assim, ao pensarmos sobre quantas e quais unidades lexicais um aprendiz de LE deve saber, parece ser mais viável tomarmos como base o conhecimento de vocabulário comum aos nativos adultos e não o léxico total da língua-alvo (NATION, 2013, 
p.13). Surge então a questão: quantas palavras, em média, sabe um falante adulto, especificamente um falante de LJ?

Muitas pesquisas sobre o léxico da LJ foram realizadas, algumas delas com o objetivo de determinar e quantificar o vocabulário dos falantes de LJ em vários estágios do desenvolvimento educacional ${ }^{47}$, dando origem a um número expressivo de listas de palavras (SHIMAMURA, 2013, p.133). De acordo com Matsuda, Kodama, Takemoto, Ishizaka, Mori, Kawamura e Yamamoto (2010, p.579), essas listas, produzidas com objetivos distintos e métodos ímpares, podem ser divididas em dois grandes grupos: as listas de vocabulário básico (kihongoi), doravante LVB, e as listas de vocabulário de base (kisogoi), doravante LVdB. Os conceitos de ambos são semelhantes, mas as motivações são diferentes. Ao conjunto de palavras determinadas essenciais a um público ou âmbito específicos, dá se o nome de vocabulário básico.

Os itens lexicais são selecionados de acordo com uma finalidade em particular e, quase sempre, para fins educacionais. Em contraposição, o vocabulário de base se refere ao conjunto de palavras que formam o núcleo mínimo da língua. Integram esse tipo de lista as palavras que apresentam alta frequência de uso, alto grau de abrangência semântica e/ou alta exclusividade semântica.

Segundo o Kokuritsu Kokugo Kenkyûjo (2000, p. 96), os métodos mais comumente utilizados para a elaboração de LVB são cinco: 1) selecionar a partir do vocabulário de base da língua; 2) de acordo com o registro de frequência de uso das palavras; 3) a partir da compreensão ou não da palavra pelas crianças; 4) a partir do levantamento das palavras que são usadas nos materiais didáticos em cada nível de ensino; e 5) a partir da opinião de especialistas.

Dentre essas listas, destacamos o trabalho de Sakamoto (1958), denominado "Kyôiku kihon goi $^{48}$. Tendo em mente nosso questionamento, consideramos que esse foi o primeiro inventário de palavras que refletiu uma provável extensão do léxico de um adulto japonês com escolarização básica concluída. O objetivo do autor era determinar quais palavras deveriam ser ensinadas ao longo dos anos da educação básica obrigatória ${ }^{49}$ e as dispor em

\footnotetext{
${ }^{47}$ De acordo com o Kokuritsu Kokugo Kenkyûjo (2000), até o momento da publicação de sua obra intitulada "Nihongo kihon goi - bunken kaidai to kenkyû", registravam-se 122 estudos relacionados a esse tema. Essa instituição de pesquisa publica em língua japonesa e inglesa. Nesse trabalho, fazemos a referência a essa instituição na língua em que se encontra a obra consultada. Em inglês, essa instituição é denominada National Institute for Japanese Language and Linguistics (NINJAL).

${ }^{48}$ Vocabulário Básico para Educação.

${ }^{49}$ No Japão, o ensino obrigatório compreende nove anos, divididos de maneira semelhante ao nosso Ensino Fundamental I e Ensino Fundamental II (MINISTRY OF EDUCATION, CULTURE, SPORTS, SCIENCE AND TECHOLOGY JAPAN, 2016).
} 
uma lista para usos educacionais. As palavras arroladas foram obtidas a partir da junção de outras quatro listas elaboradas anteriormente com desígnios distintos (SAKAMOTO, 1943; KOKUSAI BUNKA SHINKÔKAI, 1944; TANAKA, 1954; KOKURITSU KOKUGO KENKYÛJO, 1952), que, após compiladas, geraram um total de 45.000 unidades lexicais.

Em seguida, todas foram avaliadas, uma a uma, por um grupo de cinco professores de LJ que as julgaram básicas ou não. O conceito de palavra adotado é de unidade significativa mínima livre ou presa, que pode ser classificada como unidade lexical (representa um conceito ou uma noção) ou gramatical (exerce alguma função gramatical). A unidade utilizada para contabilizar as palavras foi a ocorrência única, ou seja, registraram-se as palavras com significados diferentes apenas na primeira manifestação (tokens).

Após a exclusão das palavras que se repetiam e que não foram consideradas básicas, chegou-se ao total de 22.500 unidades lexicais, distribuídas numericamente nos anos escolares da seguinte forma:

Tabela 1 - Distribuição do número de unidades lexicais por ano escolar

\begin{tabular}{|c|c|c|c|c|}
\hline & $\begin{array}{c}\text { Anos Iniciais da } \\
\text { Educação Primária }\end{array}$ & & $\begin{array}{c}\text { Anos Finais da } \\
\text { Educação Primária }\end{array}$ & $\begin{array}{l}\text { Anos da Educação } \\
\text { Secundária }\end{array}$ \\
\hline$\overline{\mathrm{A} 1}$ & 2.500 palavras & B1 & 2.500 palavras & C1 2.500 palavras \\
\hline \multirow[t]{5}{*}{$\mathrm{A} 2$} & 2.500 palavras & B2 & 2.500 palavras & C2 2.500 palavras \\
\hline & & B3 & 2.500 palavras & C3 2.500 palavras \\
\hline & & & & C4 2.500 palavras \\
\hline & \multirow[t]{2}{*}{ Total: 5.000 palavras } & & Total: 7.500 palavras & \multirow[t]{2}{*}{ Total: 10.000 palavras } \\
\hline & & & Total final: 22.5000 & \\
\hline
\end{tabular}

O inventário de Sakamoto serviu como base para diversos estudos posteriores, dentre eles, a LVB elaborada pelo Kokuritsu Kokugo Kenkyûjo (2009), mais recente e atualizada. O delineamento do estudo é similar ao de Sakamoto, mas o corpus de onde foram extraídas as palavras foram sete listas (SAKAMOTO, 1958; SAKAMOTO, 1984; TANAKA, 1956; IKEHARA, 1957; JIDÔ GENGO KENKYÛKAI, 1962; CHÛÔ KYÔIKU KENKYÛJO, 1984; KOKURITSU KOKUGO KENKYÛJO, 1984), incluindo a do próprio Sakamoto, e o número total final de itens é 27.234, resultado coerente com os objetivos de revisar e atualizar os dados. 
Com base nesses dois estudos, podemos considerar que um falante nativo de LJ adulto e com escolaridade básica completa domina cerca de 28.000 palavras. Esse número se refere ao vocabulário fundamental, aquele ensinado obrigatoriamente durante a educação básica por ser considerado necessário para a comunicação diária. Diferenças na formação, predileções, profissão, entre outros fatores, podem elevar ou diminuir essa quantidade. Esse total, se comparado ao número de palavras de um dicionário, é bem menor, mas ainda é numericamente expressivo, representando um desafio aos aprendizes de LJ como LE.

O desempenho linguístico e o conhecimento lexical estão intimamente ligados, consequentemente todo aprendiz de LE almeja ter a mesma extensão lexical que um nativo da língua-alvo. No entanto, segundo Nation (2013, p.14), esse deve ser um objetivo de longoprazo, pois não é essencial no início da aprendizagem. O autor explica que, ao invés de focar na quantidade, é importante escolher bem as palavras a serem ensinadas no estágio inicial. De acordo com Nation (2013), o vocabulário de uma língua pode ser dividido em quatro categorias:

- Vocabulário de alta frequência - palavras que representam $87 \%$ das unidades lexicais em todos os tipos de texto.

- Vocabulário técnico - representam cerca de 3\% das palavras em um texto técnico.

- Vocabulário acadêmico - representam $8 \%$ dos vocábulos presentes nesse tipo de texto.

- Vocabulário de baixa frequência - ocorrem raramente, cerca de 2\% das palavras nos textos em geral.

Sendo assim, do ponto de vista pedagógico, o primeiro é o mais importante e deve ser trabalhado prioritariamente, tendo em vista seu alto grau de ocorrência e potencial de uso. Os demais são limitados a contextos específicos e representam uma porcentagem muito baixa dentro de um texto.

Em termos numéricos, o vocabulário de alta frequência da língua inglesa é composto por 2.000 palavras e cobre cerca de $87 \%$ de qualquer texto. E no caso da LJ, quantas palavras compõem o vocabulário de alta frequência?

Uma possível resposta para essa pergunta pode ser encontrada no estudo desenvolvido pelo Kokuritsu Kokugo Kenkyûjo (1984). O objetivo era “obter uma LVB padrão composta pelas palavras que devem ser aprendidas primeiro, como base para que o estudante estrangeiro de LJ consiga desenvolver os estudos de sua área, assim como seu 
treinamento profissional” ${ }^{״ 5}$. (KOKURITSU KOKUGO KENKYÛJO, 1984, p. 1 - tradução nossa).

Do ponto de vista metodológico, a construção dessa lista se distingue das outras pelo uso de um corpus diferente. Enquanto as demais trabalharam com palavras de dicionários ou listas elaboradas anteriormente, nessa optou-se pelo uso do tesauro Bunrui goi hyô (KOKURITSU KOKUGO KENKYÛJO, 1964). Trata-se de um conjunto de unidades lexicais relacionados genérica e semanticamente sobre determinada área de conhecimento. O tesauro apresenta uma organização diferente ao do dicionário ou de uma lista e não deve ser confundido com um dicionário de sinônimos (MOTTA, 1987).

A pesquisa foi realizada em duas fases. Na primeira, vinte e dois especialistas da área de ensino de LJ e de LE avaliaram os 36.000 termos constantes no tesauro Bunrui goi hyô, marcando "um" nas palavras consideradas essenciais para o cumprimento do proposto como objetivo para a LBV. A partir dos resultados, listaram-se as 6.000 palavras mais pontuadas. $\mathrm{Na}$ segunda etapa, 17 pesquisadores, os mesmos da primeira fase, mas em menor número, tiveram que decidir quais das 6.000 palavras deveriam ser ensinadas prioritariamente, atribuindo "dois" às que assim julgassem. As 2.000 mil palavras mais pontuadas formaram uma segunda lista. Os números 6.000 e 2.000 não foram determinados por nenhum motivo em especial, levou-se em consideração apenas a regularidade dessas quantidades nas pesquisas gerais de vocabulário básico em LE (KOKURITSU KOKUGO KENKYÛJO, 1984, p.5).

Vemos que o critério para a eleição dos termos foi o grau de essencialidade com relação aos objetivos propostos. Do ponto de vista didático-metodológico, tem seu valor por indicar o número e os termos que devem ser ensinados prioritariamente. Contudo, por se tratar de uma LBV, trata-se de um vocabulário condicionado às necessidades de um grupo e situação de uso específicos, podendo não refletir o vocabulário de alta-frequência da LJ. Parece-nos que um estudo para a construção de uma LVdB, elaborada a partir do critério de taxa de frequência, seja mais adequado para responder à pergunta sobre o vocabulário de altafrequência da LJ.

Nesse caso, podemos citar o trabalho de Matsuda et al. (2010). A autora sugere que 5.000 termos são necessários para cobrir $80 \%$ das palavras usadas em textos gerais da LJ. Esse dado é resultado de uma pesquisa realizada com o objetivo de estabelecer um vocabulário de base, construído a partir dos critérios de frequência e familiaridade, para a

50 留学生等外国人の日本語学習者が、専門領域の研究または職業訓練に入る基礎として初めに学習す ベき日本語の一般的、基本的な語彙について妥当な標準を得る。 
elaboração de comunicados públicos de fácil compreensão, visando o entendimento por parte dos estrangeiros residentes no Japão.

O corpus resultante da extração teve como fonte quatro sites japoneses: o "Wikipédia", "Yahoo Perguntas", "Jornal de Economia do Japão", e o "Livedoor Blog", escolhidos devido à abrangência dos temas abordados. O primeiro passo foi o levantamento total de palavras presentes em cada site, expresso na primeira coluna da tabela abaixo. Em seguida, foram excluídos nomes próprios (lugares e pessoas), símbolos e palavras desconhecidas, resultando no total mostrado na segunda coluna da tabela. A terceira coluna é o número resultante de palavras que ultrapassaram $90 \%$ de ocorrência nos textos dos sites, um dos critérios utilizados para se definir quais termos integrariam a lista. A última coluna especifica o tipo de corpus:

Tabela 2 - Quantidade de palavras extraídas de cada corpus

\begin{tabular}{ccccc}
\hline & $\begin{array}{c}\text { Total de } \\
\text { palavras }\end{array}$ & $\begin{array}{c}\text { Total de } \\
\text { palavras } \\
\text { excluídas \#1 }\end{array}$ & $\# 2$ & Tipo de corpus \\
\hline Wikipedia & 171.772 .307 & 792.685 & 7.278 & $\begin{array}{c}\text { Texto acadêmico } \\
\text { I in ollaoem formal } \\
\text { Texto oral }\end{array}$ \\
$\begin{array}{c}\text { Yahoo! Perguntas } \\
\text { Jornal de Economia } \\
\text { do Japão }\end{array}$ & 57.679 .832 & 162.097 & 3.870 & $\begin{array}{c}\text { Linguagem coloquial } \\
\text { Texto acadêmico } \\
\text { Linguagem formal }\end{array}$ \\
\hline Livedoor Blog & 1.424 .278 .564 & 86.296 & 4.210 & $\begin{array}{c}\text { Texto oral } \\
\text { Linguagem coloquial }\end{array}$ \\
\hline
\end{tabular}

\#1 Excluídos nomes próprios (lugares e pessoas), símbolos e palavras desconhecidas.

${ }^{\# 2}$ Em ordem decrescente, palavras que ultrapassaram mais de $90 \%$ de frequência.

(Fonte: MATSUDA et al., 2010, p.580 - tradução nossa)

Definidas as palavras de cada corpus com taxa de frequência superior a 90\%, seguiuse para a unificação das listas. As palavras que apareceram em todas as listas tiveram suas taxas de frequência somadas e foram ordenadas, da mais recorrente para a menos. Os primeiros 5.000 termos foram escolhidos para compor a LVdB em construção.

Outro passo dado nessa pesquisa foi a submissão dessas 5.000 palavras a cinco avaliadores, que as classificaram em familiar ou não, por meio da atribuição de pontos de uma escala, onde sete é familiar e um é não familiar. As palavras que receberam pontuação superior a 6.5 correspondem ao total de 4,149. Esses mesmos termos cobrem cerca de $80 \%$ de todo o corpus utilizado na pesquisa. 
Por fim, Matsuda et al. (2010, p. 582) também comparou os termos de sua LVdB com as palavras exigidas em cada nível do Exame de Proficiência em Língua Japonesa. A tabela a seguir mostra o número total de palavras ${ }^{51}$ exigidas em cada nível do exame, excluindo as dos níveis anteriores:

Tabela 3 - Número de palavras exigidas em cada um dos níveis do Exame de Proficiência em Língua Japonesa

\begin{tabular}{cccc}
\hline Nível & Total de palavras & Nível & Total de palavras \\
\hline Nível 1 & 2.977 & Nível 3 & 701 \\
Nível 2 & 3.648 & Nível 4 & 755 \\
\hline
\end{tabular}

(Fonte: MATSUDA et al, 2010, p. 582 - tradução nossa)

A primeira observação a ser feita é a respeito da disparidade do número total de palavras de ambas as listas. A razão disso pode ser atribuída ao fato de que o exame de proficiência avalia também níveis de conhecimento avançado, por isso, no total de palavras, constam termos mais específicos, que não figuram na LVdB de Matsuda et al (2010, p.582).

A autora também chegou à conclusão de que as palavras presentes tanto em sua LVdB quanto nas listas dos níveis mais baixos do exame (níveis 4 e 3 ) também são as que foram avaliadas com um maior grau de familiaridade, atestando que essas palavras são realmente as que pertencem ao vocabulário de base da LJ (MATSUDA et al, 2010, p.582). A tabela a seguir mostra o número de termos comuns em ambas as listas que receberam pontuação superior a seis e a proporção em relação ao total de palavras. A última linha diz respeito às palavras que constam na $\mathrm{LVdB}$, mas não na lista de palavras do exame:

Tabela 4 - Número de sobreposição de palavras por níveis do exame

\begin{tabular}{lllllll}
\hline & $7+$ & Proporção & $6+$ & Proporção & Total & Proporção \\
\hline Nível 1 & 180 & $6.0 \%$ & 650 & $21.8 \%$ & 680 & $22.8 \%$ \\
Nível 2 & 814 & $22.3 \%$ & 1532 & $42.0 \%$ & 1.572 & $43.1 \%$ \\
Nível 3 & 363 & $51.7 \%$ & 474 & $67.6 \%$ & 481 & $68.6 \%$ \\
Nível 4 & 529 & $70.1 \%$ & 624 & $82.6 \%$ & 646 & $86.6 \%$ \\
Sem nível & 453 & & 1.158 & & 1.359 & \\
\hline
\end{tabular}

(Fonte: MATSUDA et al, 2010, p. 582 - tradução nossa)

51 Os dados usados pela autora correspondem à antiga versão do exame. Em 2010, o teste sofreu uma reformulação, com o acréscimo de mais um nível, sendo o "nível um" o mais avançado e o "nível cinco" o mais básico. Até o momento não há nenhuma publicação oficial que explicite claramente o conteúdo mínimo de cada nível nessa nova versão. 
De acordo com as pesquisas apresentadas aqui, um falante de LJ nativo adulto com escolaridade básica concluída domina ao menos 28.000 itens lexicais. Desse montante, o número necessário de palavras para cobrir $80 \%$ de um texto qualquer é de aproximadamente 5.000 unidades lexicais, as quais correspondem ao vocabulário de alta frequência da LJ. De todas as listas citadas, tomamos como referência nesta investigação a LVdB de Matsuda et al (2010).

A escolha das unidades lexicais para ensino está condicionada ao nível do aprendiz e aos seus objetivos com relação à língua. No entanto, independente desses fatores, o vocabulário de alta frequência não pode ser negligenciado, merecendo prioridade devido a seu potencial de ocorrência.

Em nossa pesquisa, trabalharemos com aprendizes em estágio inicial de aprendizagem. Sendo assim, tomaremos como referência as listas citadas acima para escolher as palavras alvos de nosso experimento a partir do vocabulário de alta frequência da LJ.

\subsection{O ensino do léxico em LE}

Nesta subseção discutimos o léxico a partir da perspectiva do ensino-aprendizagem. Estando conscientes das características fundamentais e da complexidade desse componente da língua, buscamos identificar como esse vem sendo tratado pelas principais metodologias de LE e quais são as abordagens especificas para o ensino do léxico. Por fim, apresentamos a AL e o léxico da LJ a partir da perspectiva dessa proposta pedagógica, uma vez que nos propomos a analisar suas contribuições para o ensino sistematizado do léxico da LJ.

\subsubsection{O tratamento dado ao léxico nos métodos de ensino de LE}

$\mathrm{Na}$ história do ensino de LE observamos que o léxico sempre esteve presente na agenda de estudos de professores e aprendizes, haja vista sua condição de elemento constituinte da língua. Entretanto, a maneira como foi concebido, abordado e o grau de atenção que recebeu dentro do processo de ensino-aprendizagem diferiram de acordo com as concepções teóricas relacionadas à língua e à aquisição da linguagem que marcaram cada época. 
Existem várias metodologias e abordagens de ensino de LE, mas optamos por explorar o Método Gramática-Tradução, o Método Direto, o Método Áudio-Lingual, a Abordagem Comunicativa e a Abordagem Natural, por considerarmos que essas são representativas na história do ensino-aprendizagem de línguas. Usamos o modelo proposto por Richards e Rodgers ${ }^{52}$ (1986, p.28) para descrevê-los em seus níveis de abordagem, organizacional e procedimental. O levantamento das atividades habitualmente aplicadas em cada um dos métodos foi realizado a partir do trabalho de Larsen-Freeman (2003) de descrição das técnicas e princípios dos métodos de ensino por meio de observações de aulas reais de English as a Second Language (ESL) ${ }^{53}$.

Dessa forma, a seguir, descrevemos os citados métodos e abordagens de ensino de LE e analisamos suas escolhas pedagógicas diretamente relacionadas ao léxico, com enfoque no tipo de instrução (direta ou indireta) e nas atividades/exercícios destinados para o estudo de novas palavras.

Não discorreremos nesse momento sobre a Abordagem Lexical. Consideramos mais adequado abordá-la em uma seção à parte e exclusiva, seção 2.2.2, em virtude da necessidade de uma discussão extensa e pormenorizada, por se tratar de parte do nosso objeto de estudo.

\section{Método Gramática-Tradução}

O Método Gramática-Tradução (MGT) é o mais antigo dos métodos de ensino de LE. Em meados do século XIV, as línguas modernas passam a fazer parte do currículo das escolas europeias e o MGT, até o momento empregado no ensino das línguas clássicas, foi adotado para a prática pedagógica nas salas de aula durante o período de 1840 a 1940.

Os princípios que embasam esse método são de base estruturalista. A língua é concebida como um sistema composto por regras que devem ser aprendidas e memorizadas. A linguagem a ser ensinada é a literária, em detrimento da oral, pois é considerada uma boa amostra da língua-alvo devido à acurácia gramatical. O erro não é tolerado, sendo papel do professor corrigir e oferecer aos estudantes as respostas corretas (LARSEN-FREEMAN, 2003, p.17-18).

\footnotetext{
52 Richards enquadra as atividades no nível organizacional e as técnicas no nível procedimental, como itens distintos. Contudo, em alguns momentos, utilizaremos a palavra "atividade" (entre aspas) com o sentido de "técnica", assim como Almeida Filho, por considerarmos a primeira como uma possibilidade da segunda.

${ }^{53}$ Inglês como segunda língua.
} 
O objetivo do método é tornar os aprendizes capazes de lerem e traduzirem textos literários escritos na língua-alvo. Nenhuma ou muito pouca atenção é dada ao desenvolvimento das habilidades de produção oral e compreensão auditiva, tornando-se claro que a comunicação não é o alvo da aprendizagem. Não há por parte dos aprendizes iniciativa para comunicar e nem interação entre os mesmos.

Para atingir tal objetivo, o domínio dos componentes gramaticais da língua-alvo é considerado essencial. Explicações extensas sobre a gramática, aplicação de regras gramaticais em exemplos e comparações entre as línguas envolvidas fazem parte das técnicas de ensino desse método. As principais atividades são tradução e interpretação de textos literários e são completamente controladas pelo professor. O principal parâmetro para avaliação do aprendiz é o desempenho na realização de traduções de uma língua para a outra. A L1 é usada sem nenhum impedimento para explicar e traduzir, adotando a posição de mediadora e sistema linguístico de referência para a aprendizagem da LE (STERN, 1983 apud RICHARDS; RODGERS, 1986) $)^{54}$.

Em função dos objetivos de aprendizagem e da concepção de proficiência em LE da MGT, o vocabulário exercia uma função importante, embora fosse explorado de forma limitada. As novas unidades lexicais eram selecionadas de acordo com os textos literários empregados para leitura, ou seja, grande parte do vocabulário aprendido era dispensável dado seu caráter obsoleto. Aprendia-se o léxico via instrução direta, por meio de memorização de listas bilíngues organizadas por campos semânticos, uso de dicionários e explicações etimológicas da palavra.

Essas são as principais características do MGT, mas deixamos por último a descrição das técnicas que se voltam prioritariamente ou parcialmente ao ensino de nosso objeto de estudo: o léxico.

Larsen-Freeman (2003, p.19-20), após acompanhar uma aula conduzida por um professor adepto do MGT, teceu várias observações com o intuito de apontar e localizar na prática os procedimentos e princípios inerentes a esse método.

Dentre as nove técnicas levantadas, quatro são atividades que objetivam o estudo do léxico da língua-alvo, sendo elas: 1) lista de palavras - memorização de listas de palavras na língua-alvo e seus equivalentes na língua materna; 2) sinônimos e antônimos - atividades como localização de antônimos de uma lista de palavras no texto e definição de palavras do texto com o uso de sinônimos; 3) preenchimento de lacunas - consiste na atividade de 
preencher adequadamente lacunas em frases com o novo vocabulário ou algum item gramatical específico; 4) formulação de frases - os aprendizes produzem frases usando o vocabulário aprendido na aula.

A lista de palavras é uma atividade usada para memorização, pode ser elaborada em ordem alfabética ou por classe gramatical. Os adeptos desse tipo de atividade acreditam que para aprender uma palavra a memorização é o melhor caminho (OXFORD; CROOKALL, 1990, p 10). Embora essa atividade mostre-se pouco significativa para a aprendizagem de vocabulário, Nation (1990) pontua dois pontos positivos das listas de palavras: estimula a autonomia do aprendiz e possibilita a aprendizagem de muitas unidades lexicais, ainda que superficialmente, em um curto período de tempo. Oxford e Crookall (1990, p 10-11) oferecem duas sugestões para torná-las mais proveitosas: fazer com que os aprendizes decidam as palavras que constarão nas listas ou fazê-los dispor as palavras por temas ou tópicos.

A atividade denominada sinônimos e antônimos propicia uma possibilidade de associação, mas o conhecimento desenvolvido por meio dessa atividade é limitado às habilidades receptivas e de reconhecimento.

$\mathrm{Na}$ atividade de preenchimento de lacunas, a tarefa se resume a preencher espaços em branco de orações ou diálogos com palavras contidas em uma lista pré-determinada.

A quarta atividade, formulação de frases, como o próprio nome diz, consiste em elaborar frases com as palavras aprendidas. Produção espontânea e nova exige do aprendiz pensar sobre a forma das palavras e as combinações (sintáticas, semânticas e pragmáticas) necessárias para produzir um enunciado com sentido, tratando-se de uma atividade de relevante complexidade.

O MGT imperou por cem anos, mas foi alvo de muitas críticas durante esse período. Especialistas em ensino de línguas insatisfeitos com os resultados do método - os aprendizes sabiam "sobre" a língua, mas não sabiam usá-la - deram início ao chamado Movimento de Reforma, sob a liderança de Henry Sweet, Wilhelm Vietor e Paul Passy. Esses estudiosos alegavam que o MGT não tinha nenhum embasamento teórico e defendiam serem necessários princípios metodológicos fundamentados em análises científicas da língua e estudos da psicologia. O resultado disso são mudanças bruscas no tratamento e nas concepções acerca da língua e do processo de aprendizagem, tais como: valorização da língua falada, preocupação com a fonética, uso de diálogos representativos de expressões usadas no dia a dia, ensino dedutivo da gramática e produção de significado na língua-alvo sem intervenção da L1 
(SWEET, 1899 apud RICHARDS; RODGERS, 1986) ${ }^{55}$. Essa nova onda dá origem ao Método Direto.

\section{Método Direto}

O Método Direto (MD) propõe aprender a língua-alvo de maneira direta, sem intermédio da LM e sem traduções. Nasceu na Europa, na primeira metade do século XIX, e foi propagado nos Estados Unidos por Lambert Sauver e Maximilian Berlitz (RICHARD; RODGERS, 1986, p.9).

Os princípios que norteiam esse método foram delineados durante o Movimento de Reforma, marcado por pesquisas sobre o ensino de LE pautadas em princípios naturais de aprendizagem e pelo surgimento de metodologias naturais fundamentadas pela hipótese de que a aquisição de LE e de LM ocorrem da mesma forma. A língua passa a ser vista como um instrumento para a comunicação (RICHARD; RODGERS, 1986, p.11). Logo, o principal insumo para o ensino de LE é a linguagem oral, muito valorizada nesse método. Há a preocupação em dispor insumos significativos aos aprendizes, razão pela qual os temas e o vocabulário contemplados nas aulas são selecionados conforme seu potencial de uso no cotidiano. Todas as habilidades linguísticas (falar, ouvir, ler e escrever) são trabalhadas desde o início, mas prioriza-se a oralidade que deve anteceder qualquer tipo de atividade. (LARSEN-FREEMAN, 2003, p. 29).

O objetivo do método é fazer com que os aprendizes pensem diretamente na línguaalvo ao se comunicarem. Por conseguinte, a L1 é proibida em sala de aula, até mesmo dicionários bilíngues não são permitidos. As explicações e as palavras novas são introduzidas oralmente na língua-alvo. Para que os aprendizes compreendam, o professor utiliza figuras, imagens, gestos, teatralizações e objetos reais, mas nunca a tradução. Espera-se que a gramática seja aprendida por deduções feitas a partir de exemplos de uso. Os aprendizes são incentivados a falarem espontaneamente e na língua-alvo, mas o professor deve corrigir eventuais erros de pronúncia e gramaticais.

A habilidade oral é abordada de maneira sistemática, recorrendo a atividades de pergunta-resposta organizadas em uma ordem crescente de dificuldade. A interação ocorre 
entre professor-aprendiz e aprendiz-aprendiz, os quais são vistos como parceiros no processo de aprendizagem.

Em virtude do pressuposto teórico de que LE e LM são aprendidas da mesma forma, não havia nenhum tipo de instrução explícita de vocabulário. Acreditava-se que a aprendizagem ocorria naturalmente, a partir de percepções visuais e auditivas do sujeito, não havendo motivo para nenhum tipo de intervenção pedagógica para direcionar a atenção do aprendiz (TRÉVILLE, 2000, p. 18 apud MARQUES, 2012, p. 24). ${ }^{56}$

Quanto às atividades de vocabulário, identificamos apenas uma que consideramos estar, pelo menos em parte, envolvida com o ensino de unidades lexicais novas: o preenchimento de lacunas. Apesar de já termos discutido essa atividade no MGT, há uma sutil diferença na forma como é realizada no MD. No primeiro, exige-se a colocação de uma unidade lexical previamente memorizada, enquanto no segundo o preenchimento deve ser feito com base na interpretação da frase e de forma livre, sem palavras pré-estabelecidas. (LARSEN-FREEMAM, 2003, p.30).

Observamos que o MD não tem a preocupação em aplicar atividades direcionadas exclusivamente ao vocabulário, mas emprega uma atenção especial no planejamento de procedimentos que julga viabilizar a aprendizagem do mesmo. De acordo com as orientações desse método de ensino, toda palavra nova deve ser apresentada em um mínimo de contexto; o vocabulário a ser ensinado, em especial nos níveis iniciais, é escolhido cuidadosamente e deve ser simples, útil para a comunicação e de alta frequência. As palavras já aprendidas devem ser usadas para aprender novas unidades lexicais, pois nenhuma oportunidade de prática de uso e contextualização deve ser desperdiçada; e o professor deve evitar enunciados curtos e solicitar de seus aprendizes a produção de enunciados completos (LARSENFREEMAM, 2003, p.30).

O MD foi empregado nas escolas regulares da França e da Alemanha no ensino de línguas modernas, mas no resto da Europa e nos Estados Unidos foi adotado apenas nos cursos comerciais de línguas. A recusa em adotá-lo nas escolas regulares é resultado da percepção de que algumas características do método dificultam o seu uso em escolas de ensino regular, como por exemplo, a restrição de uso da L1, que demanda professores nativos ou com excelente nível de proficiência e muito tempo para explicar tudo na língua-alvo. Pela mesma razão, por volta de 1920, na França e na Alemanha dá-se início a uma flexibilização

${ }^{56}$ TRÉVILLE, M.C. Vocabulaire et Apprentissage d'une langue Seconde. Québec: Les Éditions Logiques, 2000. 
no uso do método, resultando em um ajuste com a inserção de atividades gramaticais. (RICHARDS; RODGERS, 1986, p.11).

No caso específico dos Estados Unidos, os objetivos do método não condiziam com os dos aprendizes, que necessitavam e preferiam ser capazes de ler textos acadêmicos em uma LE do que se comunicar na língua-alvo. Por essa razão, desponta em 1930 o chamado Movimento do Controle do Vocabulário (MCV), marcado pela proposta da Abordagem para a Leitura (AL), a qual advogava que o desenvolvimento da habilidade de leitura depende do domínio de um vocabulário fundamental. Essa é a primeira vez que o vocabulário é considerado como elemento central na aprendizagem de LE, fazendo com que seleção e controle de palavras a serem ensinadas passassem a ser questões relevantes no ensino de LE. A partir do MCV começam a ganhar destaque pesquisas sobre frequência de uso das palavras (THORNDIKE; LORDE, 1944; WEST, 1953).

A mudança no cenário político recorrente da Segunda Guerra Mundial impôs a urgência de comunicação em várias línguas. O Método Áudio-Lingual nasceu com a missão de atender a esse objetivo.

\section{Método Áudio-Lingual}

A Segunda Guerra Mundial trouxe a necessidade de pessoas poliglotas, com domínio, em especial, das línguas dos países envolvidos na guerra. Esse fato levou as autoridades americanas a investir em projetos voltados à elaboração de um método de ensino de LE rápido e eficaz. O período pós-guerra manteve a atenção voltada ao ensino de LE em decorrência do aumento do número de estrangeiros no país que precisavam aprender o inglês rapidamente. Diante do cenário, linguistas da época reuniram esforços para elaborar um método com bases teóricas sólidas. O resultado disso é o Método Áudio-Lingual, doravante MAL (RICHARDS; RODGERS, p. 47).

Desenvolvido por Charles Fries da Universidade de Michigan, os princípios desse método estão fortemente pautados nas teorias da Psicologia Behaviorista (SKINNER, 1957) e da Linguística Estrutural (BLOOMFIELD, 1933). A teoria behaviorista de aprendizagem afirma que o ser humano é capaz de manter um amplo repertório de comportamentos, aprendidos a partir do processo de estímulo-resposta-reforço. Já os estruturalistas defendem que a língua é um sistema composto pelos níveis fonológico, morfológico e sintático, os quais se combinam para produzir significados e esse processo é observável e pode ser descrito 
(RICHARDS; RODGERS, 1986, p. 47). O resultado dessa combinação é um método que tem como objetivo capacitar os aprendizes a se comunicarem por meio da formação de hábitos linguísticos na língua-alvo.

Durante as aulas, a L1 é evitada ao máximo para que não haja interferências negativas no processo de aquisição. As produções dos aprendizes são imitações de modelos fornecidos pelo professor ou por materiais de áudio e são controladas e monitoradas. Para que não ocorra a formação de maus hábitos, os erros, tanto gramaticais quanto de pronúncia, são sempre corrigidos e evitados. A gramática é aprendida de forma dedutiva, pois o objetivo é que os aprendizes consigam usar a língua-alvo de maneira automática, sem analisar sua estrutura. Todos os conteúdos e atividades são trabalhados na seguinte ordem: ouvir, falar, ler e escrever, evidenciando a centralidade das habilidades oral e auditiva. A língua é tida como essencialmente falada, razão pela qual a linguagem oral é valorizada (RICHARDS; RODGERS, 1986, p. 47).

O principal tipo de insumo são diálogos contendo estruturas padrões da língua-alvo. O procedimento adotado nas aulas é regular e rígido. Antes de usarem o livro didático, os aprendizes realizam um extenso treino oral de tudo o que está escrito na lição e memorizam todos os diálogos. Em seguida, frases dos diálogos são isoladas para serem treinadas em exercícios orais de fixação. Por fim, são realizadas atividades de leitura e escrita (LARSENFREEMAN, 2003, p. 40).

O MAL não demonstra engajamento com o ensino do léxico. O tratamento do vocabulário é uma tarefa secundária restrita a aquisição por exposição, que ocorre durante as atividades que visam a automatização das estruturas fonológicas e gramaticais da língua-alvo. Todas as unidades lexicais novas são introduzidas de forma controlada e apenas para serem utilizadas nos exercícios de fixação.

A partir da leitura das observações de Larsen-Freeman (2003, p.47), arriscamo-nos a destacar duas atividades que, ainda que de maneira indireta, contribuem para a aprendizagem de vocabulário. O primeiro é o exercício de substituição, pelo qual se solicita ao aprendiz encaixar palavras em um mesmo eixo sintagmático e na mesma posição. O segundo exercício é o de completar lacunas do diálogo. Consiste em preencher com as palavras adequadas as lacunas do diálogo memorizado anteriormente.

Em ambas as atividades, o enfoque não é aprender novas unidades lexicais ou aprofundar o conhecimento das já conhecidas. Entretanto, como nessas atividades as palavras são manipuladas de forma individual, boa parte da atenção dos aprendizes recai sobre elas. 
Com relação aos procedimentos realizados durante a aula, notamos uma técnica que consideramos ser produtiva para a aprendizagem do léxico: a utilização de pares-mínimos. O professor ensina os sons da língua-alvo a partir da comparação de palavras fonologicamente e morfologicamente parecidas, a fim de aguçar a compreensão auditiva e aprimorar a pronúncia dos aprendizes. Essa técnica direciona a atenção para as características fonológicas e morfológicas das palavras, embora as dimensões semântica e pragmática não sejam contempladas em profundidade (LARSEN-FREEMAN, 2003, p. 49).

O período áureo do MAL foi entre as décadas de 50 e 60 . O seu caráter imitativo e coercitivo começou a ser questionado diante do fato de que as situações reais de comunicação são diferentes das treinadas em sala de aula. A consequência desse descompasso são aprendizes incapazes de lidar com diálogos espontâneos e imprevistos, resultando em fracasso na comunicação (LARSEN-FREEMAN, 2003, p. 50).

Essa insatisfação, mais uma vez, mobiliza estudiosos na busca de novas alternativas para área de ensino de LE. De acordo com Larsen-Freeman (2003, p.73), dos anos 50 aos anos 70, surgiram diversas propostas metodológicas humanistas, tais como a Suggestopédia, o Silent Way, Community Language Teacher, e o Total Physical Response. Embora não tenham tido um impacto relevante, contribuíram ao proporem considerar questões afetivas e psicológicas no processo de ensino-aprendizagem. Esses métodos abriram caminho para o Movimento Comunicativo no Ensino de Línguas, que culminou no surgimento da Abordagem Comunicativa.

\section{Abordagem Comunicativa}

No final dos anos 60, diferentemente dos Estados Unidos que tinham suas salas de aula de LE dominadas pelo MAL, na Inglaterra imperava o Ensino de Línguas Situacional, primeira manifestação da Abordagem Comunicativa (AC).

Novas concepções sobre a língua e o processo de aprendizagem colocaram em xeque as teorias que sustentavam o MAL. Destacamos as contribuições de Hymes (1972), autor do conceito de competência comunicativa, e Wilkins (1976), um dos idealizadores do Ensino de Línguas Situacional. De acordo com Hymes, o uso efetivo da língua também é determinado por fatores pragmáticos e sociolinguísticos, e não apenas pela competência linguística (RICHARDS; RODGERS, 1986, p.70). Em linha semelhante de pensamento, o linguista britânico Wilkins discute o descuido dos métodos vigentes com relação às outras dimensões 
da língua: a funcional e a comunicativa. Segundo o autor, o uso comunicativo é resultado de produção de significado composto por categorias nocionais (conceitos de tempo, sequência, quantidade, etc.) e categorias de função comunicativa (pedidos, convites, etc.). Seu posicionamento contribuiu para a construção do termo comunicativo, assim como proveu bases para a elaboração do Syllabus Nocional-Funcional

De acordo com a AC, a língua é um sistema que tem como funções principais a interação social e a comunicação. Os aprendizes aprendem a língua-alvo ao se comunicarem e negociarem significados, por meio de atividades essencialmente comunicativas, significativas, contextualizadas e que envolvam os aprendizes na execução de tarefas linguísticas. Priorizase a compreensão e a produção (significado) em detrimento do estudo de regras gramaticais (forma).

O objetivo não é ser um método prescritivo, mas sim, um conjunto de princípios norteadores para o ensino de LE, a fim de desenvolver nos aprendizes uma competência comunicativa constituída por conhecimentos de ordem estrutural, semântica e pragmática. Ou seja, todos os esforços se concentram em capacitar os aprendizes a usar a língua para comunicação. Nesse processo, o professor tem a função de facilitador e a responsabilidade de criar situações que propiciem a comunicação. O aprendiz assume o papel de comunicador, que deve se esforçar para se expressar independente de seus erros, pois o mais importante é a transmissão da mensagem e não a precisão gramatical. Considera-se o erro como consequência natural do processo de aprendizagem e como uma ferramenta que auxilia o professor a pensar e agir em prol do desenvolvimento de seus aprendizes (LARSENFREEMAN, 2003, p.76).

As quatro habilidades são trabalhadas desde o início, sempre com alguma intenção comunicativa e de forma espontânea. A língua não é estudada de forma analítica, mas o professor pode oferecer explicações caso o aprendiz requeira. A L1 é evitada na medida do possível, mas seu uso é permitido em situações em que a língua-alvo é mais conveniente. Os materiais adotados são livros textos, materiais baseados em tarefas e materiais autênticos, com preferência pelos dois últimos (LARSEN-FREEMAN, 2003, p.132).

Ainda que a AC tenha proposto muitas mudanças para o ensino de LE, pouco contribui com relação ao ensino sistematizado do léxico. Wilkins (1972 apud ZIMMERMAN, 1997, p. 14) ${ }^{57}$, acredita que o léxico de uma LE é adquirido pela exposição considerável a ele, sendo desnecessário ensinar explicitamente novas palavras. Zimmerman (1997, p.13) aponta

\footnotetext{
${ }^{57}$ WILKINS, D. Linguistics in language teaching. London: Edward Arnold. 1972.
} 
que "pouca atenção explícita foi dada ao vocabulário nas publicações tanto teóricas quanto metodológicas sobre o Syllabus Nocional-Funcional". ${ }^{58}$ Desse modo, é claro o entendimento na $\mathrm{AC}$ de que o léxico é adquirido de forma natural e por exposição, sem que haja a necessidade de um trabalho pontual com o vocabulário.

A AC tem como princípios básicos a contextualização e o foco no significado, por isso a aprendizagem das palavras da língua-alvo tende a ocorrer de maneira favorável para o desenvolvimento da competência lexical, mas pode ser potencializada se os professores dispuserem mais atenção ao vocabulário, organizando e sistematizando seu ensino.

Com relação as atividades, como mencionado acima, a $\mathrm{AC}$ assume que o léxico é adquirido de forma natural, de maneira semelhante à L1, portanto todas as atividades desenvolvidas em uma aula planejada de acordo com os princípios dessa abordagem servem também ao propósito de aprender novas palavras. Larsen-Freemam (2003, p.133) aponta as seguintes atividades:

- Sentenças embaralhadas: os aprendizes reorganizam frases embaralhadas de um texto.

- Jogos de linguagem: jogos projetados para proporcionar a prática comunicativa com o uso de itens linguísticos pré-determinados, tais como o vocabulário.

- Dramatização (role play): são exercícios que possibilitam simular comunicação em diferentes contextos e papéis sociais.

- História com imagens: os aprendizes criam uma história a partir de imagens.

As atividades típicas da AC são contextualizadas e colocam em uso as quatro habilidades da língua em situações comunicativas que simulam a vida real, em contraposição aos métodos de ensino anteriores e suas atividades descontextualizadas e semicontextualizadas, que focavam o conhecimento dos aspectos formais das palavras.

De fato, as atividades da $\mathrm{AC}$ são as que têm mais potencial para a formação de um conhecimento rico de vocabulário. No entanto, isso só se concretizará se o professor mantiver esse objetivo claro em seus planejamentos, para que haja uma sistematização e um controle do ensino de vocabulário.

${ }^{58}[\ldots]$ little explicit attention has been given to vocabulary in either theoretical or methodological publications about notional and functional syllabi”. 


\section{Abordagem Natural}

A Abordagem Natural (AN) foi proposta em 1977 por Tracy Terrel e representa uma tentativa de incorporar princípios naturalistas observados em estudos sobre a aquisição de LM ao ensino de LE. Em 1983, o autor dá mais um passo no desenvolvimento de sua abordagem e se junta à Stephen Krashen, para juntos lançarem a obra intitulada The Natural Approach: Language Acquisition in the Classroom. Enquanto Krashen se dedicou à fundamentação teórica da nova proposta pedagógica, Terrel contribui com orientações sobre a forma de implementação e os procedimentos de sala de aula (RICHARDS; RODGERS, 1986, p.178).

Nessa abordagem, a comunicação é vista como a função primária da língua, por conseguinte o enfoque recai sob o ensino de habilidades comunicativas. A compreensão ocupa a posição central, em detrimento ao estudo de aspectos formais, pois se acredita que a aquisição só ocorre quando há o entendimento de mensagens na língua-alvo. Consequentemente, o léxico é visto como um importante elemento da língua, como apontam Richards e Rodgers (1986, p.180 - tradução nossa) ao afirmarem que:

\footnotetext{
A importância do vocabulário é salientada, por exemplo, sugerindo a ideia de que uma língua é essencialmente seu léxico e apenas de forma inconsequente a gramática determina como o léxico é explorado na produção de mensagens. ${ }^{59}$
}

A teoria de aprendizagem que embasa a AN é a Teoria de Aquisição da Linguagem de Krashen (1983), composta por cinco hipóteses. A primeira discorre sobre a distinção entre aquisição e aprendizagem, fenômenos entendidos como distintos de acordo com o autor. $\mathrm{O}$ resultado da aquisição é a linguagem adquirida, e ocorre de forma inconsciente e mediante a real necessidade de comunicação. Já a aprendizagem gera a linguagem aprendida, ou seja, um conjunto de conhecimentos sobre as regras da língua-alvo obtido por meio de um esforço consciente em contexto formal de ensino (RICHARDS; RODGERS, 1986, p.181).

A segunda é a Hipótese da Ordem Natural. Alguns estudos apontam que há estruturas gramaticais de alto teor de dificuldade que parecem ser adquiridos antes de outras consideradas mais simples. A Hipótese da Ordem Natural se propõe a explicar esse fenômeno ao afirmar que as regras da LM, seja ela qual for, são adquiridas em uma ordem natural previsível, e processo semelhante ocorre na aquisição de uma LE. No entanto, a ordem que vemos na aquisição da LM não é necessariamente a mesma do processo de aquisição de uma

\footnotetext{
${ }^{59}$ The importance of the vocabulary is stressed, for example, suggesting the view that a language is essentially its lexicon and only inconsequently the grammar that determines how the lexicon is exploited to produce messages.
} 
LE e, muitas vezes, nem mesmo a que é usada para se estabelecer a sequência gramatical das aulas (RICHARDS; RODGERS, 1986, p.182).

A Hipótese do Insumo é colocada como uma das mais importantes no processo de aquisição de LE. O insumo, amostra da língua-alvo ao qual os aprendizes são expostos, deve estar um pouco acima do estágio atual e ser compreensível (i+1), ou seja, passível de entendimento pelo contexto, por interpretações, por associações ao qualquer outro tipo de auxílio extralinguístico. Além disso, para que o insumo seja considerado ótimo, ele deve ser relevante para os aprendizes, não sequenciado gramaticalmente e oferecido em quantidade suficiente (RICHARDS; RODGERS, 1986, p.182).

A quarta é a Hipótese do Monitor. Essa está relacionada à aprendizagem, pois se trata do uso da linguagem aprendida, do conhecimento sobre as regras da língua para o monitoramento da produção linguística. O monitor entra em ação quando o sistema adquirido produz enunciados que necessitam de correções, mas isso só ocorre caso haja três condições: tempo para escolher e aplicar a regra, foco na forma e conhecimento das regras (RICHARDS; RODGERS, 1986, p.181).

A última é a Hipótese do Filtro Afetivo, que está relacionada a fatores psicológicos que influenciam no processo de aquisição de uma LE, tais como a ansiedade, a motivação intrínseca e a autoconfiança. Aprendizes que se mostram abertos à aprendizagem da línguaalvo aproveitam melhor o insumo recebido e tendem também a buscar por mais. Isso ocorre quando o filtro afetivo está baixo, permitindo o acesso à parte do cérebro que é responsável pela linguagem. Os aprendizes com filtro afetivo alto não são receptivos ao insumo e, consequentemente, esse se torna incompreensível e bloqueia a aquisição. Segundo essa hipótese, uma sala de aula ideal é aquela que trabalha para a diminuição das barreiras psicológicas, motiva os aprendizes e promove a autoconfiança e atitudes receptivas à aprendizagem (RICHARDS; RODGERS, 1986, p.183).

Sobre os aspectos organizacionais, indica-se a adoção de um syllabus situacionalfuncional, com os conteúdos reunidos em torno de tópicos e objetivos comunicativos definidos a partir das necessidades dos aprendizes. De acordo com os autores, o syllabus deve ser pensado a partir desses critérios para que o filtro afetivo dos aprendizes se mantenha baixo (RICHARDS; RODGERS, 1986, p.184)

Com relação ao papel do aprendiz, esse está condicionado à fase de aquisição linguística em que o mesmo se encontra. No "estágio pré-produção", espera-se o envolvimento nas atividades, mas não necessariamente produzindo na língua-alvo. São recorrentes nesse estágio atividades que podem ser respondidas com gestos e atividades de 
indicação (apontar figuras) e de identificação (de objetos descritos, de pessoas, de situações, entre outras). O "estágio de produção precoce" é marcado pela participação do aprendiz em atividades que exigem respostas com palavras ou frases curtas, preenchimento de lacunas ou reprodução de expressões fixas. No terceiro estágio, denominado "fase do discurso emergente", os aprendizes participam de atividades como role play e jogos, envolvem-se em resolução de problemas em grupo e expressam informação pessoal e opinião. Dessa forma, podemos entender que o principal papel do aprendiz é se dedicar durante as atividades comunicativas. Além disso, são de responsabilidade do aprendiz informar seus objetivos comunicativos, empenhar-se para compreender o insumo, decidir quando iniciar e aprimorar a produção na língua-alvo, decidir com o professor se haverá ou não atividades de aprendizagem da língua e, se sim, quanto tempo será despendido nesse tipo de atividade (RICHARDS; RODGERS, 1986, p.186).

Ao professor são atribuídas três funções básicas. A primeira se refere ao papel de fornecedor primário de insumo compreensível e dicas não linguísticas para auxiliar os aprendizes na compreensão. Por essa razão, de acordo com Richards e Rodgers (1986, p.187) "a abordagem natural exige um papel muito mais central para o professor do que muitos métodos de comunicação contemporâneos". ${ }^{60}$ Também é papel do professor garantir e manter um ambiente de sala de aula agradável, interessante e amigável visando manter baixo o filtro afetivo dos aprendizes. De acordo com os princípios da AN, esse tipo de ambiente de sala de aula pode ser cultivado evitando cobrar dos aprendizes produções na língua-alvo antes de se sentirem preparados, não corrigindo os erros dos aprendizes e abordando temas de interesse dos aprendizes (RICHARDS; RODGERS, 1986, p.188).

Sobre os procedimentos de sala de aula e os tipos de atividades de ensino e aprendizagem, todos os esforços se concentram na tarefa de apresentar aos aprendizes insumo compreensível na língua-alvo. A fim de evitar tensões, nos estágios iniciais nenhuma atividade de produção é requerida, e a fala do professor se limita a objetos de sala de aula e a figuras ilustrativas. Ao avançarem para o estágio seguinte, o professor passa a fornecer aos aprendizes oportunidades de produção de respostas simples. Com a fala clara e pausada, faz perguntas de respostas fechadas (sim, não ou de apenas uma palavra). Não se espera do aprendiz nenhum tipo de produção inédita, ou seja, o uso de vocabulário e construções linguísticas que nunca tenha visto antes. Quando a competência linguística dos aprendizes permite, a fala é transferida para os membros da sala. Nesse estágio, atividades com foco na

\footnotetext{
${ }^{60}$ The Natural Approach demands a much more center-stage role for the teacher than do many contemporary communicative methods.
} 
comunicação significativa são realizadas em pares, grupos ou com o envolvimento de todos os membros da sala na resolução de algum problema. Richards e Rodgers (1986, p. 186) afirmam que não há nada de novo nas atividades propostas pela $\mathrm{AN}$, pois são adaptações de atividades típicas de outras abordagens de ensino. De acordo com os autores:

\footnotetext{
O que caracterizes a Abordagem Natural é o uso de técnicas familiares no âmbito de um método que se concentra em fornecer insumo compreensível, minimizar a ansiedade do aprendiz e maximizar sua autoconfiança (RICHARDS; RODGERS, 1986, p.186). ${ }^{61}$
}

Dessa forma, assim como ocorre em outras abordagens comunicativas, não há atividades específicas para a aprendizagem do léxico na AN. Adota-se a instrução indireta para o ensino do léxico, em decorrência do entendimento de que as unidades lexicais novas são adquiridas de maneira incidental, durante a realização de outras atividades.

Os métodos/metodologias e abordagens de ensino apresentados até o momento são marcos de fases significantes da evolução histórica da área de ensino de línguas. Observamos que o interesse em tornar mais fácil e rápida a difícil tarefa de aprender uma LE se tornou, pouco a pouco, uma questão amplamente explorada em pesquisas científicas. Nesse processo, o vocabulário ora ocupou uma posição primária, ora secundária, mas durante muito tempo pouco se falou sobre a relação entre a competência lexical em LE a as habilidades linguísticas, bem como sobre o que, de fato, significa conhecer uma palavra e quais são os procedimentos didático-metodológicos adequados para a aprendizagem do léxico da língua-alvo (MEARA, 1980). Ou seja, mesmo nos momentos em que se considerou o léxico como importante, não houve uma preocupação na área científica de se discutir questões relacionadas a esse elemento da língua.

\subsubsection{A Abordagem Lexical}

Como já mecionado, o léxico começa a ter visibilidade a partir dos anos 70, momento em que pesquisadores da área de ensino de LE passam a adotar o tema em suas pesquisas. Dentre esses, destacamos Michael Lewis e sua Abordagem Lexical (AL). O evento que marca o surgimento dessa abordagem de ensino é a publicação, em 1993, do livro The Lexical

\footnotetext{
${ }^{61}$ What caracterizes the Natural Approach is the use of familiar techniques within the framework of a method that focuses on providing comprehensible input, minimizes learner anxiety, and maximizes learner selfconfidence.
} 
Approach: The state of ELT and a way forward. Anos depois, em 1997, o autor lança o livro intitulado Implementing the lexical approach: putting theory into practice. Segundo Lewis:

\begin{abstract}
A Abordagem Lexical abraça tudo o que a Abordagem Comunicativa sugere. Sua adição principal é o reconhecimento do léxico, ao invés da estrutura da língua, como um princípio organizador que afeta tanto o conteúdo quanto à metodologia (1993, p.VI - tradução nossa). ${ }^{62}$
\end{abstract}

Como mencionado pelo próprio autor, a AL compartilha de muitos dos princípios da AC. Sua inovação está na proposta de deslocamento da ênfase na estrutura para a ênfase no léxico. Lewis advoga que o léxico, ao invés da estrutura, é a base da língua. O autor ainda afirma que o conhecimento sobre a estrutura da língua é importante, mas que esse só é passível de uso quando se conhecem as palavras necessárias para se produzir o enunciado desejado.

O nome pode nos levar a crer que se trata de uma abordagem inteiramente direcionada ao ensino-aprendizagem do léxico, mas não é esse o caso. A AL é uma proposta para o ensino de línguas, e não só de vocabulário. No entanto, embora façamos uma descrição breve e geral da AL, nossa intenção é discutir nesta seção os aspectos teórico-metodológicos dessa abordagem que dizem respeito diretamente ao ensino-aprendizagem do léxico.

$\mathrm{Na}$ AL, a língua é concebida como uma habilidade para uso comunicativo, haja vista sua principal função de criar e trocar significados de acordo com um propósito ou situação comunicativa, de modo que o objetivo de aprendizagem é a comunicação bem-sucedida e não o domínio do sistema linguístico (LEWIS, 1993, p.50).

A partir da perspectiva da AL, a língua é essencialmente lexical, e não gramatical, uma vez que envolve basicamente nominalização, isto é, nomeação de conceitos, razão pela qual deve ser vista como um léxico gramaticalizado e não como uma gramática lexicalizada. Dessa forma, Lewis (1997, p.23) abandona a dicotomia vocabulário/gramática e classifica as unidades lexicais de acordo com sua posição em um espectro com as polaridades gramática e léxico, ou seja, as unidades lexicais podem ser mais ou menos lexicalizadas, a depender de sua carga semântica. Toda palavra é tratada como tal, nenhuma é relegada a existir apenas como um item gramatical.

O léxico representa a totalidade de palavras de uma língua. Essa totalidade, na AL, não é vista como um montante composto por muitas palavras individuais. Lewis apresenta o

\footnotetext{
${ }^{62}$ The Lexical Approach develops many of the fundamental principles advanced by proponents of Communicatives Approaches. The most important difference is the increased understanding of the nature of lexis in naturally occurring language, and its potential contribution to language pedagogy."
} 
conceito de itens lexicais que é definido, pelo próprio autor, da seguinte maneira: "os itens lexicais, então, são unidades independentes socialmente sancionadas. Muitos são palavras, mas muitos consistem em uma unidade de multipalavras" (1993, p. 90).

Com base nisso, o autor defende que a língua é estocada e processada em blocos (chunks), ou frases prontas, que são acionadas de uma única vez conforme a necessidade da situação comunicativa. Os itens lexicais de multipalavras devem ser introduzidos desde os níveis iniciais e apresentados como um todo, sem que haja explicações sobre sua estrutura interna. Argumenta-se que a recuperação a partir da memória como um todo (chunks), reduz as dificuldades de processamento, de forma que o ensino de itens lexicais isolados é desvantajoso, visto que exige muito tempo, esforço e delimita o potencial de expressão e uso dos aprendizes (1997, p.184). Lewis afirma que:

O ponto de vista padrão divide a língua em gramática (estrutura) e vocabulário (léxico); a Abordagem Lexical desafia essa visão fundamental da língua. Em vez disso, a Abordagem Lexical argumenta que a língua consiste em chunks que, quando combinados, produzem contínuos textos coerentes. Os chunks são de diferentes tipos e quatro tipos básicos são identificados. Um deles consiste em palavras isoladas, enquanto todos os outros são itens de multipalavras (1997, p.7 - tradução nossa). ${ }^{63}$

Dessa forma, a estratégia central da AL é conscientizar o aprendiz sobre a organização da língua em chunks e levá-los a desenvolver a habilidade de identificar e decompor qualquer texto (oral ou escrito) em itens lexicais de todos os tipos, particularmente os de multipalavras.

Lewis argumenta que:

O léxico fornece os chunks que compõem a língua. Se os aprendizes fizerem bom uso da língua com a qual se encontram, gradualmente desenvolverão uma consciência dos diferentes tipos de chunks. O léxico reúne elementos da aprendizagem de línguas normalmente tratados separadamente - gramática, vocabulário e pronúncia; ao trazê-los juntos, ajuda os aprendizes a transformarem insumo em insumo linguístico internalizado. O trabalho do professor é incentivar boas estratégias de aprendizagem que ajudem os aprendizes a perceber a língua de forma mais precisa, tornando assim mais provável que o insumo se torne insumo linguístico internalizado (1997, p.58 - tradução nossa). ${ }^{64}$

\footnotetext{
${ }^{63}$ The standard view divides language into grammar (structure) and vocabulary (words), the Lexical Approach challenges this fundamental view of language. Instead, the Lexical Approach argues that language consists of chunks which, when combined, produce continuous coherent text. The chunks are of different kinds and four different basic types are identified. One of these consists of single words while all the others are multi-word items.

${ }^{64}$ Lexis provides the component chunks of language and, if learners are to make best use of the language they meet they need gradually to develop an awareness of chunks of different kinds. Lexis brings together elements of language learning previously usually treated separately - grammar, words and pronunciation; in bringing them together it helps learners turn input into intake.
} 
Segundo Lewis, "a verdadeira aprendizagem parece resultar de uma relação simbiótica contínua entre a experiência, a reflexão sobre essa experiência, e eventual internalização integral da mesma" (1993, p. 55 - tradução nossa). Isto posto, para a AL, a aprendizagem é não linear, provisória e intermitente. Em decorrência disso, o desenvolvimento das aulas é planejado de acordo com o paradigma OHE (observation - hypothesise - experiment $)^{65}$, ao invés do velho paradigma PPP (presente - pratice - produce). ${ }^{66}$ As longas explanações do professor dão lugar a ação investigativa dos aprendizes. No lugar de respostas, o professor deve oferecer perguntas que induzam a observar, hipotetizar sobre e experimentar a línguaalvo.

Inerente às tentativas e às descobertas, ações comuns em salas de aulas orientadas pelo paradigma OHE, está a possibilidade de erro, o qual é visto nessa abordagem como intrínseco ao processo de aprendizagem e qualquer ação para evitá-lo é contraprodutiva. Diante de um erro, o professor deve evitar a correção direta e recorrer à reformulação e/ou ao feedback (LEWIS, 1993, p.173).

Segundo a AL, são estratégias importantes para a aprendizagem a observação (noticing), atividades de conscientização (consciousness-raising activities) e o registro (record). O primeiro se refere a direcionar a atenção dos aprendizes especificamente para as características lexicais do insumo ao qual são expostos. Lewis afirma que:

\begin{abstract}
A ideia central da observação permeia todos os exercícios e atividades da Abordagem Lexical. Apesar de concordar com a proposição central de Krashen na Abordagem Natural, a de que nós adquirimos a língua através da compreensão de mensagens, a Abordagem Lexical diverge em um aspecto importante. A Abordagem Natural afirma que a aprendizagemconsciente não tem influência na aquisição. Se Krashen estiver certo, então toda a instrução formal não faz sentido, e até mesmo impede a comunicação. Porém, apesar de isto acontecer mais vezes do que muitos professores admitam, não acontece sempre. $\mathrm{O}$ ensino ajuda, precisamente quando ele encoraja a transição do insumo para o insumo linguístico internalizado. O sentido e a mensagem são essenciais, mas exercícios e atividades que ajudem o aprendiz a observar a L2 com mais acurácia asseguram a formulação de hipóteses mais claras e rápidas acerca da $\mathrm{L} 2$ e, desta forma, auxiliam na aquisição, que é baseada em um ciclo constantemente repetido de observar - fazer hipóteses - experimentar (OHE) (1997, p. 52 - tradução nossa). ${ }^{67}$
\end{abstract}

\footnotetext{
${ }^{65}$ Observar - criar hipóteses - experimentar

${ }^{66}$ Apresentar - praticar - produzir.

67 The key idea of 'noticing' informs all Exercises and Activities in the Lexical Approach. While agreeing with Krashen's main proposition in The Natural Approach, namely We acquire language by understanding messages, the Lexical Approach differs in one important respect. The Natural Approach claims conscious learning has no influence on acquisition. If Krashen is right, then all formal instruction is pointless, or even impedes acquisition. While this is more often the case than many teachers admit, it is not always so. Teaching helps, precisely when it encourages the transition from input to intake. Meaning and message are primary, but Exercises and Activities which help the learner observe or notice the L2 more accurately ensure quicker and more carefully-formulated hypotheses about L2, and so aid acquisition which is based on a constantly repeated Observe-HypothesiseExperiment cycle
} 
As atividades de conscientização se concentram nas habilidades receptivas e visam garantir a percepção dos aprendizes com relação às características do insumo recebido, de maneira a promover uma maior consciência e sensibilização com relação à língua, tornando mais propensa a transição do insumo para o insumo linguístico internalizado. Vale mencionar a concepção de Lewis com relação aos termos atividade e exercício. Para o autor, atividades "são geralmente feitas de forma cooperativa em pares ou em grupos e têm resultados linguísticos e não linguísticos"68, ao passo que exercícios "são geralmente solitários, feitos por escrito e têm um foco exclusivamente linguístico" ${ }^{69}$ (LEWIS, 1997, p.83 - tradução nossa). Embora distintos, na AL ambos são considerados importantes ferramentas pedagógicas quando elaborados de forma a cumprir com o objetivo de conscientizar e sensibilizar os aprendizes sobre os chunks da língua-alvo.

Com relação ao registro, a AL propõe incentivar os aprendizes a manter um caderno lexical, organizado de maneira diferente dos tradicionais cadernos de vocabulário, diante da seguinte justificativa:

\begin{abstract}
A importância do caderno lexical precisa ser enfatizada. Em The Power of Reading, Stephen Krashen observou: às vezes um pouco de escrita pode fazer uma grande diferença. Como de costume, ele enfatiza a importância do insumo, explicando que a melhor maneira de melhorar a sua escrita não é escrever mais, mas ler mais. No entanto, ele também valoriza a escrita, pois permite que os aprendizes vejam e manipulem a língua na página, separada realmente de seu momento de uso, o que ajuda a consciência. Escrever ajuda você a pensar; como ele diz, a escrita pode torná-lo mais inteligente (LEWIS, 1997, p.77 - tradução nossa). ${ }^{70}$
\end{abstract}

O sucesso da implementação da AL, segundo Lewis (1997, p.85), depende da atenção dada ao processo de desenvolvimento da percepção dos aprendizes com relação às multipalavras que formam os chunks da língua-alvo. Para que ocorra a observação e percepção desses chunks, o caderno lexical desempenha um papel importante, pois acredita-se que o registro escrito adequado ajuda na transformação do insumo para o insumo linguístico internalizado. A concepção de linearidade é rejeita pela AL na seleção, organização e registro dos itens lexicais, pois esse critério não evidencia a forma como as unidades lexicais se

68 "....are usually best done co-operatively in pairs or groups".

69 "....are usually solitary, paper-based and have an exclusively linguistic focus".

${ }^{70}$ The importance of the Notebook needs emphasising. In The Power of Reading Stephen Krashen observed: Sometimes a little bit of writing can make a big difference. As usual, he emphasises the importance of input, explaining that the best way to improve your writing is not to write more, but to read more. But he also values writing because it enables learners to see and manipulate the language on the page, detached from actually using it, which helps awareness. Writing helps you to think; as he puts it Writing can make you smarter. 
combinam. Mapas mentais, tabelas de colocações, árvore de palavras, ou seja, formas não lineares de registro do léxico são preferíveis em abordagens que partem das concepções de que a língua é composta por léxico gramaticalizado e que se organiza a partir da combinação de blocos de língua (LEWIS, 1993, p. 43). Abordaremos com mais atenção na seção de metodologia as características do caderno lexical, dos exercícios e atividades propostos pela AL, uma vez que esses são parte das intervenções realizadas na sala experimental desta pesquisa.

Com relação aos aspectos procedimentais, a AL traz implicações metodológicas em especial nos estágios iniciais. Sugere-se privilegiar as habilidades receptivas, em especial a compreensão auditiva, com o argumento de que inicialmente apenas reproduzimos língua a qual fomos anteriormente expostos, fazemos generalizações e criamos reportório para futuras produções inéditas (LEWIS, 1993, p.7). A escrita extensiva deve ser abordada o mais tarde possível, pois advoga-se que a língua oral é a atividade responsável pela aquisição natural da linguagem e os aprendizes devem ser expostos abundantemente a esse tipo de língua (LEWIS, 1993, p.195).

A aprendizagem de vocabulário não contextualizada é considerada uma estratégia válida, tendo em vista que as abordagens de ensino centradas no significado focam a habilidade de comunicação do aprendiz e para tal o conhecimento lexical é indispensável e precisa ser desenvolvido o quanto antes. Desse modo, expandir o vocabulário do aprendiz nos níveis iniciais é primordial (LEWIS, 1993, p. 195).

A gramática é reconhecida como uma habilidade receptiva. Salienta-se a importância de incentivar os aprendizes a compararem a língua-alvo com ela mesma, ou com a línguamaterna, para a formulação de hipóteses sobre suas regras. Dessa forma, a LM não é vista como um empecilho, mas sim como um recurso que pode ser usado na aprendizagem da língua-alvo (LEWIS, 1993, p. 195). Além disso, diante da produção de um aprendiz, o professor deve se ater ao conteúdo da mensagem e não às possíveis falhas de ordem estrutural. Lewis afirma que:

\footnotetext{
Ao defender a Abordagem Lexical eu não discuto que a gramática e os erros não importam; tal argumento seria irresponsável. Estou, no entanto, argumentando que a ênfase deve sempre caber ao conteúdo, e que isso deve sustentar cada decisão metodológica feita pelo professor $\left(1993\right.$, p. 195 - tradução nossa). ${ }^{71}$
}

\footnotetext{
${ }^{71}$ In arguing for a Lexical Approach I do not argue that grammar and error do not matter; such an argument would be irresponsible. I am, however, arguing that emphasis must always lie upon content, and that this should under-pin every methodological decision made by the teacher.
} 
O tempo de fala do professor é valorizado, pois pode configurar-se em bom insumo compreensível para os aprendizes. No entanto, alerta-se que a fala do professor deve focar no “aqui e agora” e não em monólogos e leituras (LEWIS, 1993, p.195).

Para além de todas as características desejáveis em um professor que atua de acordo com os princípios do ensino de línguas comunicativo, para a AL cabe ao professor também o papel adicional de conscientizar os aprendizes com relação aos itens lexicais, a fim de levá-los a perceber e identificar os chunks que compõem a língua-alvo, sendo indispensáveis em suas aulas tempo destinado ao trabalho de conscientização sobre a relevância e a forma como o léxico se organiza. Com isso, o professor também assume os papéis de editor, ao selecionar o melhor insumo a ser oferecido; consultor, ao fornecer o feedback necessário para o desenvolvimento tanto da competência linguístico-comunicativa de seus aprendizes, quanto da autonomia na aprendizagem dos mesmos; e como um facilitador e avaliador do processo de aprendizagem, não apenas do produto final (LEWIS, 1993, p.188).

Apresentamos algumas características gerais da AL que julgamos relevantes para o entendimento de nosso trabalho. A seguir, abordamos o conceito de léxico proposto pela AL, buscando identificar as categorias de itens lexicais no léxico da LJ.

\subsubsection{O léxico da língua japonesa do ponto de vista da Abordagem lexical}

Segundo Vilela (1994, p.10), léxico diz respeito à totalidade de palavras de uma língua, enquanto vocabulário diz respeito a uma parte desse léxico, formado por palavras de uma determinada área de conhecimento. Para a AL, essa totalidade não corresponde a um montante composto por palavras isoladas, mas sim, por itens lexicais. Lewis classifica esses itens lexicais de formas diferentes, conforme sua formação ou interação. A primeira grande divisão feita pelo autor enquadra os itens lexicais em duas categorias: palavra ou multipalavra.

A categoria palavra refere-se ao tipo mais básico de item lexical, pois são os que podem ser empregados sozinhos sem prejuízo de entendimento da mensagem e se substituídos em um enunciado ocasionam uma mudança total de significado. Essas palavras também podem ser classificadas de acordo com seu grau de informação e situadas dentro de um espectro com as polaridades léxico e gramática, podendo então ser mais lexicalizadas ou mais gramaticalizadas (LEWIS, 1993, p.91). No caso da LJ, as unidades lexicais a seguir são exemplos de palavras lexicalizadas devido ao alto teor de informação contido nelas: 

Eki (estação)
Oishii (gostoso)
Toire (banheiro)
Anzen (seguro)
$I k u$ (ir)
Kau (comprar)

Em contraposição, palavras como no, kara, wo, ni, de ${ }^{72}$ encontram-se no polo oposto, logo são mais gramaticalizadas. No entanto, vale ressaltar que para Lewis todas devem ser tratadas como palavras, diferente do tratamento dado aos mencionados no, kara, wo, ni e de, tradicionalmente ensinados apenas como itens gramaticais.

A categoria de multipalavras compreende os itens lexicais formados por mais de uma unidade lexical, os quais são subdivididos em: polipalavras, colocações e expressões institucionalizadas.

Segundo Lewis (1993, p.92), as polipalavras são itens lexicais formados por duas palavras ou mais, são consagradas e normalmente estão no dicionário. Se analisadas separadamente, podem ou não apresentar um significado diferente do obtido pela junção das duas. O falante não elabora ou analisa uma polipalavra, apenas a reconhece ou a retoma da memória como um todo (chunk). Lewis (1997, p.22 - tradução nossa) descreve as polipalavras como "palavras-com-espaços-entre elas" que possuem o status de palavras individuais na língua. Vale relembrar que a LJ não adota o espaçamento entre as palavras, de modo que a maneira de identificar polipalavras é pela interpretação da formação do item lexical. Trata-se de uma polipalavra o item lexical composto por duas unidades lexicais que, se separadas, expressam significado completo e mantêm suas formas. Outro fator que dificulta a identificação de polipalavras na LJ é o fato de que uma considerável parte do léxico dessa língua é composta por palavras formadas a partir do processo de composição (OTA, 2011, p.81). Em decorrência disso, podemos pensar que itens lexicais como mottekuru (trazer), akibin (garrafa vazia), kaimonosuru (fazer compras), karegoe (voz rouca) são polipalavras, principalmente se nos pautarmos na tradução, quando de fato são palavras compostas que representam itens lexicais simples. Temos como exemplos de polipalavras da LJ os seguintes itens

lexicais:

\footnotetext{
${ }^{72}$ No, kara, wo, ni e de são partículas de caso da língua japonesa e as traduções variam conforme o uso.
} 
Motte no hoka (fora de questão)

Ippô dewa (por outro lado)
Takushî noriba (ponto de táxi)

Karê raisu (arroz com curry)

Já as colocações se referem às combinações de palavras individuais que ocorrem naturalmente com uma frequência maior do que a aleatória. Lewis (1997, p.27 - tradução nossa) afirma que "algumas palavras são frequentemente encontradas no mesmo ambiente textual. Tais coocorrências podem ser frequentes ou raras, fortemente ou mais fragilmente ligadas ${ }^{73} \%$. Ou seja, as coocorrências podem gerar colocações fixas ou mais livres. As primeiras são um tipo de polipalavra, pois não podem ser analisadas de forma individual, caso o objetivo seja compreender o conteúdo semântico expresso pela colocação. Em contraposição, nas colocações livres, é possível visualizar individualmente cada unidade lexical e realizar trocas por palavras parceiras. Em contexto natural, as coocorrências entre as palavras não são completamente aleatórias, baseadas apenas no eixo sintagmático da língua (LEWIS, 1993, p.93). Isso explica o fato de que, muitas vezes, produzimos enunciados gramaticalmente corretos, mas que causam estranhamento ao falante nativo devido às combinações não usuais de unidades lexicais na língua-alvo. Lewis atribui esse fenômeno à arbitrariedade e convencionalidade do signo linguístico:

\begin{abstract}
A arbitrariedade se estende a todos os tipos de itens lexicais - colocações e expressões, bem como palavras individuais. Alguns itens são sancionados e alguns não são. Esta não é, contudo, uma questão de fato inalterável; novas expressões se tornam parte do léxico padrão da mesma maneira que novas palavras, mas, como já foi sugerido, a resposta "você poderia dizer isso, mas você não deveria" é central para o entendimento do léxico (1997, p. 19 - tradução nossa). ${ }^{74}$
\end{abstract}

Para a AL, não ser possível generalizar é a indicação clara de que encontramos e estocamos chunks em nosso léxico mental, argumentação de base dessa abordagem de ensino.

Como exemplo de colocação fixa na LJ, temos megane wo kakeru (usar óculos). Na LJ há o verbo tsukau (usar), mas por uma questão de convencionalidade se usa o verbo kakeru (pendurar) para expressar a ideia de usar óculos. Um aprendiz brasileiro, caso não conheça essa colocação, possivelmente optaria pelo uso do verbo tsukau, o que não seria agramatical, mas daria origem a um enunciado não convencional na LJ.

\footnotetext{
${ }^{73}$ Some words are frequently found in the same textual environment. Such co-occurrences may be frequent or rare, strongly or more loosely bound.

${ }^{74}$ Arbitrariness extends to all kinds of lexical item - Collocations and Expressions as well as individual words. Some items are sanctioned and some are not. This is not, however, a matter of unalterable fact; new Expressions do become part of the standard lexicon in the same way as new words, but, as already suggested, the answer You could say that, but you wouldn't is central to understanding lexis.
} 
As colocações livres são combinações de unidades lexicais que são (mais ou menos) livremente combináveis, com cada uma mantendo seu sentido literal. Vejamos um exemplo de colocação livre da LJ: hon wo уоти (ler livro). Ao considerarmos o verbo уоти (ler), imediatamente nos vem à mente várias unidades lexicais possíveis para uma combinação, tais como hon (livro), zasshi (revista), tegami (carta), entre outras. Ou seja, fica claro que há uma parceria entre essas palavras que dá origem às colocações. Podemos pensar que se trata apenas de uma questão semântica, mas nem tudo que é possível de "ser lido" pode ser usado com o verbo yomu. Por exemplo, a combinação jisho o yomu (ler dicionário) não é usual na LJ.

A colocação hon o yomu não é fixa, porque se reconhece a frequência de uso das unidades lexicais com outras. Além disso, a mensagem expressa não é fruto da combinação de dois termos que, se avaliados separadamente, não seriam as escolhas lexicais mais coerentes. Em outras palavras, no caso da colocação fixa megane o kakeru, poderíamos considerar o uso do verbo tsukau, mas violaria a combinação socialmente aceita. Em contraposição, ao pensarmos na palavra yoти facilmente a relacionamos com as palavras hon, zasshi, tegami, formando mais de uma parceria aceitável. Esse tipo de item lexical é extremamente valorizado na Abordagem Lexical do ponto de vista pedagógico, uma vez que propicia a produção de enunciados que soem naturais na língua-alvo.

O último tipo de item lexical são as expressões institucionalizadas. Tratam-se de frases, inteiras ou parcialmente fixas, frequentemente usadas para fins específicos, isto é, possuem um caráter pragmático. Recomenda-se que sejam ensinadas por completo, sem análise de suas partes. São consideradas muito importantes, já que proveem insumo rico para sensibilizar os aprendizes quanto aos padrões da língua-alvo. Ademais, recomenda que sejam introduzidas desde o início, pois habilitam os aprendizes iniciantes a se expressarem já nos primeiros estágios, elevando a confiança dos mesmos, fator positivo para o processo de aprendizagem de uma LE (LEWIS, 1993, p.94).

Lewis (1993, p.45) divide as expressões institucionalizadas em três tipos: as sentenças completas, os enunciados curtos e as frases cabeças. Todas têm um caráter pragmático, e ao expressá-las, o falante tem em mente executar uma função específica. Temos como exemplo de sentença completa "Chotto matte kudasai" (espere um pouco, por favor), cuja função implícita é solicitar um tempo de espera. Do segundo tipo, enunciados curtos, temos "Sore wa chotto..." (isso é um pouco...), empregado quando se quer rejeitar ou expressar desacordo com alguma ideia, convite, opinião etc. Como último exemplo, referente às frases-cabeças, citamos o "Onegai ga arun desuga..." (tenho um pedido...), o qual sinaliza um pedido que 
será realizado. Todas essas expressões institucionalizadas podem ser usadas desde o início pelo aprendiz.

A concepção de itens lexicais exige uma revisão da forma como as unidades lexicais da língua-alvo são classificadas e categorizadas e, consequentemente, também ocasiona mudanças de ordem metodológica. Assumir o léxico como elemento fundamental da língua demanda comprometimento na escolha das unidades lexicais a serem ensinadas durante as aulas. Deve-se considerar também que o insumo, nesse caso, o léxico-alvo, deve ser diversificado, significativo, compreensível e autêntico. Isso posto, em uma sequência didática que aborde a situação "fazer pedidos em restaurante", é indispensável selecionar amostras da língua com esses atributos e que contenham os variados tipos de itens lexicais, para que os aprendizes acessem os padrões da língua (lexicais e estruturais) frequentemente usados nessa situação. Por exemplo, expor aos aprendizes de LJ a expressão institucionalizada gochûmon wa ijôde yoroshiideshôka (o pedido está finalizado e correto?) e a colocação kôhî o kudasai (café, por favor) é mais benéfico do que apresentar as palavras separadamente, ou então uma lista de palavras soltas relacionadas ao tema da aula.

A AL prioriza o ensino da língua em blocos, os chamados chunks. Uma medida importante para viabilizar essa forma de ensino é sensibilizar os aprendizes quanto aos padrões de determinados itens lexicais da língua-alvo e levá-los a desenvolver a habilidade de segmentar a língua em pedaços maiores, tanto para a compreensão quanto para a produção. Isso exige a aplicação de exercícios específicos para o trabalho com o léxico, elaborados de forma a favorecer essa sensibilização. No lugar de listas de palavras com os pares LM-LE, deve-se procurar explorar todos os tipos de itens lexicais em sua integridade, por meio de exercícios que trabalhem com associações, localizações de chunks, metalinguagem, entre outros. Lewis (2000, p.132 - tradução nossa) argumenta que:

Se você aprender duas palavras separadamente, você também deverá aprender um terceiro item, a colocação correta. Separar as colocações em suas palavras componentes é fácil; mais consideravelmente difícil é juntar as palavras para formar colocações naturais ${ }^{75}$.

Nos níveis iniciais, focar no desenvolvimento do repertório lexical é de suma importância, e por isso, a aprendizagem de palavras de forma descontextualizada é uma

\footnotetext{
75 If you learn the two words separately, you must also learn a third item, the correct collocation. Separating collocations into their component words is easy; it is considerably more difficult to put words together to form natural collocations.
} 
estratégia totalmente legítima, contanto que a exploração das relações cotextuais seja preservada (LEWIS, 1993, p. 110).

$\mathrm{O}$ termo contexto se refere aos fatores situacionais e o termo cotexto designa o ambiente linguístico em que se encontra a palavra. Dito isso, Lewis (1993, p.103) defende que os elementos cotextuais são mais relevantes para determinar as escolhas nos momentos de criação de significado. $\mathrm{O}$ autor afirma que o cotexto atua como um importante suporte, porque restringe as opções na hora de escolher a palavra mais adequada para a construção de determinado enunciado.

Diante do exposto, é interessante notar que muitos dos princípios da AN e AC estão presentes na AL, mas o principal ponto de divergência é o tratamento dado ao léxico. Por essa razão, consideramos relevante abordar uma última questão: as possíveis abordagens específicas para o ensino do léxico.

\subsubsection{O ensino do léxico: explícito versus indireto}

As metodologias descritas nas seções anteriores levam em conta o ensino global da língua-alvo, ou seja, buscam desenvolver todos os aspectos linguísticos, priorizando um ou outro, a depender da posição teórica-metodológica de base. Sobre o léxico, mantém-se entre pesquisadores e professores uma discussão calorosa quanto à abordagem a ser adotada para o seu ensino em particular. Alguns defendem a aquisição incidental via instrução indireta (KRASHEN, 1989; NAGY; HERMAN, 1985), enquanto outros advogam a favor da aprendizagem por meio da instrução explícita (LEWIS, 1993; SCHMIDT, 1990).

Já Coady (1997, p.275) considera que as propostas pedagógicas encontradas na literatura podem ser categorizadas em quatro tipos de abordagens de ensino de léxico, que se diferenciam de acordo com sua posição em um continuum com polos onde em um dos extremos está a contextualização total da palavra e, no outro, o ensino isolado de unidades lexicais.

Em uma das pontas se encontra o que o autor denomina de "Apenas contexto". Abordagens que se enquadram nessa posição do continuum defendem não haver necessidade e nem justificativa para a instrução explícita de vocabulário e acreditam ser suficiente a aquisição incidental de novas palavras. Destarte, a aquisição de vocabulário é vista como uma derivação de alguma outra atividade cognitiva em foco, isto é, o aprendiz aprende novas palavras de forma inconsciente, enquanto sua atenção está direcionada para a compreensão da 
mensagem ou de outros aspectos da língua que não o vocabulário. A sustentação teórica dessa abordagem é proveniente dos trabalhos de Krashen e Terrel (1983), defensores da ideia de que o aprendiz aprende o vocabulário pela leitura extensiva de insumo compreensível, significativo e contextualizado. Os autores afirmam que a aprendizagem está condicionada à exposição a um insumo compreensível de nível i +1 , sendo i a representação da competência atual do aprendiz e 1 o conteúdo linguístico novo, o qual é compreendido pelo contexto. Muitos estudos afirmam haver uma relação causal e recíproca entre leitura e aquisição de vocabulário uma vez que a leitura é a atividade que melhor proporciona o tipo de insumo ideal para a aquisição de novas palavras (KRASHEN, 1989), mas para compreensão de um texto é indispensável a compreensão do vocabulário (LAUFER, 1997).

Como em toda proposta pedagógica, a aquisição incidental de vocabulário traz vantagens e desvantagens. De acordo com Huckin e Coady (1999), os principais benefícios são a contextualização, que pode oferecer um sentido mais rico do significado e do uso; a eficiência pedagógica, uma vez que o professor tem a possibilidade de realizar mais de uma atividade simultaneamente; e o fato de ser primordial centrar no aprendiz e individualizar o ensino, em função da necessidade de prover insumos significativos, contextualizados e adequados ao nível em que ele se encontra.

Em contraposição, Huckin e Coady (1999) apontam como desvantagem a falta de atenção à forma, pois o aprendiz se aterá ao sentido e não se preocupará em associar a forma e o significado das novas unidades lexicais. Além disso, alertam para o risco de a palavra nova não ser percebida se estiver inserida em um contexto suficiente para o entendimento da mensagem e, consequentemente, não será adquirida. Outro fator desfavorável é a possibilidade de o aprendiz inferir erroneamente o significado de uma palavra, visto que existem itens lexicais de difícil compreensão a partir do contexto, tais como expressões idiomáticas, falsos cognatos, colocações, palavras com muitos significados ou com estrutura morfológica falaciosa.

A próxima posição no continnum é a "Instrução estratégica". Embora o contexto seja considerado a principal fonte de aquisição de vocabulário, essa abordagem alerta que há a possibilidade de os aprendizes não conseguirem fazer bom uso dessa ferramenta. Consequentemente, caracteriza-se por enfatizar o ensino de estratégias de aprendizagem visando habilitar o aprendiz a aprender novas palavras de maneira efetiva a partir do contexto. Ademais, os proponentes dessa abordagem argumentam ser imperioso aliar à aquisição incidental de vocabulário o suporte adicional de tarefas voltadas à aprendizagem das unidades lexicais da língua-alvo, sem que haja necessariamente instrução explícita (COADY, 1997, 
p.276). Paribakht e Wesche (1997) lançam um questionamento favorável pertinente a essa abordagem:

[...] se o desenvolvimento sistemático do vocabulário em L2 é desejado, ele não pode ser deixado nas mãos dos aprendizes. Os aprendizes não podem simplesmente 'captar' uma carga substancial ou específica de vocabulário sem um certo direcionamento. Dadas as limitações da instrução descontextualizada de vocabulário, a questão para a pedagogia de L2 é se a aquisição de vocabulário em L2 pode ser maximizada através da intervenção instrucional no contexto de uso significativo da língua. Especificamente, podemos elaborar tarefas que irão aumentar a eficácia da aprendizagem de vocabulário através da prática da leitura? (p. 177 - tradução nossa). ${ }^{76}$

$\mathrm{Na}$ sequência do continnum, temos a posição denominada "Desenvolvimento mais instrução explícita". De acordo com essa abordagem, nos níveis iniciais, deve-se priorizar o vocabulário de alta frequência da língua-alvo e ensiná-lo via instrução direta, com a aplicação de técnicas variadas e até mesmo memorização, destinando o uso do contexto como ferramenta de aprendizagem aos níveis mais avançados de ensino (PARIBAKHT; WESCHE, 1997, p.279). Os adeptos dessa abordagem priorizam, nos estágios iniciais, o avanço da competência lexical dos aprendizes, atribuindo uma posição de destaque ao léxico no processo de ensino-aprendizagem de LE (COADY, 1997).

Ao fim do continnum encontramos uma abordagem que sobreleva as "Atividades de sala de aula”. Caracteriza-se pelo apelo à prática de exercícios em sala de aula como meio para a aprendizagem de vocabulário, revelando um ensino com viés tradicional. As atividades provenientes dessa abordagem podem acompanhar qualquer método, uma vez que não se vinculam claramente a nenhum existente. Coady $(1997$, p.281) afirma que como consequência dessa abordagem se tem um acervo de exercícios genéricos de vocabulário que são aplicados pelos professores sem que haja uma reflexão sobre o contexto de ensino que se encontram.

As duas primeiras abordagens do continnum adotam a concepção da "aquisição incidental de vocabulário" e as duas últimas da "aprendizagem intencional de vocabulário". De acordo com Hulstijn (2001, p.271 - tradução nossa), essas podem ser entendidas como:

Atualmente, nos domínios da pedagogia aplicada de L1 e L2, aprendizagem incidental de vocabulário se refere à aprendizagem do léxico como subproduto de qualquer atividade que não seja explicitamente voltada ao ensino de vocabulário, já

\footnotetext{
${ }^{76}[\ldots]$ if systematic development of L2 vocabulary is desired, it cannot be left to the students themselves. They cannot be expected to "pick up" substantial or specific vocabulary knowledge through reading exposure without guidance. Given the limitations of decontextualized vocabulary instruction, the question for L2 pedagogy is whether Le vocabulary acquisition can be enhanced through instructional intervention in the context of meaningful language use. Specifically, can tasks be designed that will increase the effectiveness of vocabulary learning through reading practice?
} 
a aprendizagem intencional de vocabulário corresponde a qualquer atividade com o objetivo de estocar informações lexicais na memória. ${ }^{77}$

Devido às diferenças, consequentemente as formas de instrução praticadas são distintas. As abordagens que se apoiam na aquisição incidental advogam não haver necessidade de instrução direta, pois acreditam que apenas a exposição do aprendiz a novas palavras e repetidas vezes é o suficiente para adquiri-las.

Por outro lado, as abordagens que se baseiam na aprendizagem intencional afirmam que, em especial nos níveis iniciais, há a necessidade de complementar a aprendizagem incidental com instrução direta de vocabulário, conforme alertado por Hulstijn (2001, p.274 tradução nossa).

[...] é importante projetar tarefas que foquem a atenção dos aprendizes na aprendizagem do vocabulário para torná-los conscientes da importância das estratégias de aprendizagem de vocabulário eficientes. De um ponto de vista educacional, simplesmente incentivar os aprendizes a passar muito tempo na leitura e escuta, embora leve a alguma aprendizagem incidental de vocabulário, não é suficiente em si mesmo. ${ }^{78}$

Ainda que haja diferenças de posicionamento, ambas as abordagens de ensino apresentam pontos favoráveis e desfavoráveis. É inegável que a aprendizagem incidental contribui constantemente com o enriquecimento do repertório lexical dos aprendizes e que a contextualização oferece uma conceituação rica das palavras, acompanhada de exemplos de usos. Contudo, uma sólida competência lexical implica o domínio de uma gama de saberes sobre as palavras que são adquiridos de maneira muito lenta via aprendizagem incidental. Nation (2013) afirma que no início a aprendizagem incidental deve ser complementada via instrução direta do léxico. Segundo o autor, o vocabulário de alta frequência da língua-alvo deve ser aprendido o quanto antes, para que o aprendiz alcance sua independência comunicativa e adquira um suporte linguístico que elevará sua habilidade de inferência, instrumento indispensável para a própria aquisição incidental de vocabulário. Além disso, ensinar o vocabulário direcionando o foco do aprendiz para essa atividade faz com que ele perceba a complexidade das palavras e tome consciência do que ainda precisa aprender sobre as novas unidades lexicais que surgem.

\footnotetext{
77 Currently, in the applied domains of L1 and L2 pedagogy, incidental vocabulary learning refers to the learning of vocabulary as the by-product of any activity not explicitly geared to vocabulary learning, with intentional vocabulary learning referring to any activity aiming at committing lexical information to memory.

${ }^{78}[\ldots]$ it is important to design tasks which focus learners' attention on vocabulary learning and to make them aware of the importance of efficient vocabulary learning strategies. From an educational point of view, simply encouraging learners to spend much time on reading and listening, although leading to some incidental vocabulary learning, will not be enough in itself.
} 
Esta pesquisa se alinha ao posicionamento teórico do grupo de pesquisadores que advogam a favor da aprendizagem de vocabulário via instrução direta. Para o caso de qualquer língua, consideramos consistente o argumento de que, diante da complexidade do léxico, apoiar a formação da competência lexical do aprendiz apenas na aquisição incidental de vocabulário seja insuficiente e lenta. Consideramos que, tendo em vista a relação intrínseca entre o conhecimento lexical de uma LE e o desempenho nessa LE, todo o processo de aprendizagem é posto em marcha lenta quando não há nenhum esforço consciente e direcionado para o ensino do léxico da língua-alvo.

No caso da LJ, parece-nos ainda mais evidente a necessidade de um ensino sistematizado via instrução direta, tendo em vista as diferenças entre os pares de língua português-japonês. O fato dessas línguas usarem sistemas de escrita diferentes impede o aprendiz de decodificar textos que não tenham sido previamente adaptados para o ensino, cerceando as estratégias metacognitivas que levam a aquisição incidental de vocabulário. Ou seja, a forma das palavras nessa língua precisa necessariamente ser ensinada ou aprendida com a atenção do aprendiz voltada para essa atividade, pois a exposição a textos que tenham ideogramas desconhecidos é pouco proveitosa, uma vez que o aprendiz não conseguirá acessar a palavra.

Arriscamo-nos afirmar que nos níveis iniciais não existe a possibilidade de haver aquisição incidental de vocabulário em LJ, já que ao se deparar com um fonograma ou ideograma novo, o aprendiz automaticamente direcionará a sua atenção para a nova unidade lexical e buscará, no mínimo, as informações de leitura e significado. Além disso, tratam-se de línguas sem semelhanças fonológicas, morfológicas ou semânticas e não há ocorrência de cognatos, salvo os raros casos de empréstimos da LP, tornando mais difícil o uso da inferência. Acreditamos que a aquisição de vocabulário incidental é propícia a partir dos níveis intermediário e avançado, em decorrência da já provável familiaridade com o funcionamento da língua em questão, condição necessária para se fazer inferências com base na própria língua.

Vale esclarecer que consideramos a aquisição incidental o principal meio para o desenvolvimento da competência lexical do aprendiz e que o professor deve sim sempre ensinar seus aprendizes a aprender pelo contexto. Entretanto, não a consideramos suficiente.

Adotamos os princípios da AL como norte para o ensino sistematizado do léxico com instrução explícita, por se tratar de uma das propostas pedagógicas que mais atribuem importância ao léxico no processo de ensino-aprendizagem de LE. Inserimos quatro elementos dessa abordagem na sequência didática da sala experimental desta pesquisa, sendo 
eles: a) uma aula sobre o conceito de chunks e outra sobre os tipos de itens lexicais; b) exercícios complementares com foco lexical; c) atividades complementares com foco lexical; e d) elaboração de um caderno lexical.

A seguir, apresentamos o percurso e aspectos metodológicos desta pesquisa. 


\section{III - METODOLOGIA}

Neste capítulo descrevemos a metodologia empregada na execução desta pesquisa. Apresentamos na subseção 3.1 o delineamento do estudo. Na subseção 3.2 descrevemos o contexto, o perfil dos participantes, o experimento e as intervenções. Na subseção 3.3, discorremos sobre os instrumentos de coleta de dados utilizados e na subseção 3.4 os procedimentos de análise dos dados.

\subsection{Delineamento do estudo}

Muitos autores defendem o ensino sistematizado e explícito de vocabulário (SCHMIDT, 1990; PARIBAKHT; WESCHE, 1997; NATION, 2013) nos permitindo partir do pressuposto de que essa forma de ensinar contribui para o desenvolvimento da competência lexical do aprendiz de LE. Diante disso, surgiu-nos a indagação de como ensinar o vocabulário da LJ dessa maneira e ao buscarmos alternativas nos deparamos com a AL, a qual atribui ao léxico o papel de elemento central e propõe uma reformulação na forma de ensinaraprender LE.

A partir disso, levantamos a hipótese de que complementar a aquisição incidental com ensino sistematizado do léxico via instrução direta pode contribuir para o desenvolvimento de uma competência lexical sólida composta por um conhecimento rico de vocabulário. Para verificarmos a validade de dessa hipótese, delimitamos as seguintes perguntas a serem respondidas:

1) O ensino sistematizado e explícito de vocabulário norteado pelos princípios da AL contribui para a aprendizagem do vocabulário da $\mathrm{LJ}$ do ponto de vista quantitativo?

2) O ensino sistematizado e explícito de vocabulário norteado pelos princípios da $\mathrm{AL}$ contribui para a aprendizagem de vocabulário da LJ do ponto de vista qualitativo?

3) O ensino sistematizado e explícito de vocabulário norteado pelos princípios da $\mathrm{AL}$ contribui para a aprendizagem de vocabulário da LJ a curto e longo prazo? 
Sendo assim, o objetivo geral desta investigação é verificar as contribuições do ensino sistematizado e explícito de vocabulário norteado pelos princípios da AL para a aprendizagem do léxico em LJ, a curto e longo prazo, tanto quantitativamente quanto qualitativamente.

Considerando nossa hipótese e objetivo, mostrou-se mais adequada uma investigação com delineamento quase-experimental. De acordo com Campbell e Stanley (1979), estudos quase-experimentais são de natureza empírica e se distinguem pela ausência de duas características básicas da experimentação: o controle total e a aleatoriedade na escolha dos participantes.

No caso do experimento didático, Campbell e Stanley (1979, p.1) afirmam que as variáveis sofrem manipulação (variável independente) e buscam-se observar e descrever os efeitos em outras variáveis (variável dependente). Sendo assim, este estudo é uma investigação quase-experimental porque: a) temos uma variável independente - as intervenções pedagógicas baseadas na AL - e uma variável dependente - o desempenho dos alunos demonstrado nos pós-testes imediato e postergado; b) os participantes não foram escolhidos aleatoriamente e não tivemos o controle total, na medida em que não era possível controlar a exposição das palavras-alvo aos participantes fora das aulas do experimento.

Com relação às questões éticas, informamos com clareza e precisão os objetivos e procedimentos deste estudo à instituição coparticipante, aos responsáveis dos participantes e aos participantes. Após os esclarecimentos, o diretor da escola concedeu a autorização para a pesquisa e assinou o TAI - Termo de Autorização Institucional (Apêndice A) e os pais assinaram o TCLE - Termo de Consentimento Livre e Esclarecido (Apêndice B), permitindo a participação de seus filhos. Descartamos os dados dos participantes cujos os responsáveis não autorizaram a participação.

Comprometemo-nos a manter em sigilo o nome da escola e a identidade dos alunos, os quais foram substituídos por nomes falsos e códigos. Os TCLE's assinados foram recibos pela coordenação da escola e reencaminhados para a professora-pesquisadora. Embora solicitado, não obtivemos autorização para realizar nenhum tipo de gravação.

\subsection{O experimento}

O experimento ocorreu no segundo semestre de 2014 e os participantes foram os alunos de duas turmas do sexto ano do Ensino Fundamental II de uma escola particular. O primeiro passo foi a aplicação de um pré-teste para definirmos as palavras-alvo. 
Posteriormente, elaboramos as intervenções pedagógicas e iniciamos a sequência didática no grupo experimental (GE) e no grupo controle (GC). Inserimos no planejamento do GE uma aula sobre o conceito de chunks e o outra sobre os tipos de itens lexicais, exercícios e atividades extras com foco lexical e a produção de um caderno lexical, procedimentos realizados ao longo de 12 aulas. No GC não houve nenhum tipo de alteração nos planos das aulas e o programa previsto foi abordado em nove aulas. Imediatamente ao final da sequência didática e trinta dias depois, os participantes de ambas as turmas responderam ao teste VKS (Vocabulary Knowledge Scale). A seguir, descrevemos com mais detalhes o conjunto do experimento.

\subsubsection{O contexto da pesquisa}

Esta pesquisa foi realizada com aprendizes de uma escola particular, doravante Escola X, localizada na Grande São Paulo, atuante nos segmentos da Educação Infantil (EI), Ensino Fundamental I (EFI), Ensino Fundamental II (EFII) e Ensino Médio (EM). Trata-se de uma escola de período integral, com aproximadamente 450 alunos, que é mantida e administrada por uma associação nipo-brasileira. Em sua grade curricular constam a LJ como disciplina obrigatória e compulsória, da EI ao último ano do EFII, bem como atividades extracurriculares relacionadas à cultura japonesa.

Ativa há 23 anos, oferece o ensino de LJ desde sua criação. A carga horária anual dessa disciplina é de 80 horas nos segmentos da EI e EFI e 120 horas no EFII. A partir do EM, torna-se optativa, com carga horária de 80 horas. A duração das aulas é de 50 minutos, sendo duas por semana na EI, no EFI e no EM e três no EFII.

O ensino de LJ é orientado de acordo com os objetivos determinados para cada segmento. Na EI o foco é desenvolver o laço afetivo das crianças com o estudo da LJ, por meio de atividades lúdicas com temática relacionada à cultura japonesa e com conteúdo significativo para a faixa etária; no EFI, o objetivo central é capacitar os aprendizes a ler e escrever os sistemas de escrita hiragana e katakana, recorrendo a exercícios, atividades e jogos que mobilizem as competências de decodificação e registro.

Os materiais didáticos usados nesses dois segmentos são produzidos pelos professores responsáveis pela disciplina. A partir do EFII, prioriza-se o ensino da LJ para fins comunicativos e o estudo do terceiro sistema de escrita: os ideogramas. O material didático adotado nesse segmento é o Marugoto: Nihon no Kotoba to Bunka. 
A proposta da escola é ensinar a LJ a partir de uma abordagem multicultural, a fim de despertar nos aprendizes a habilidade de compreender e respeitar o outro a partir da reflexão sobre as diferenças e semelhanças existentes entre a sua própria cultura e a cultura de seu interlocutor. Com relação ao objetivo linguístico, espera-se que ao final do EFII os aprendizes alcancem a competência linguística comunicativa equivalente ao nível quatro do Exame de Proficiência em Língua Japonesa (JLPT).

Embora o planejamento pedagógico da disciplina seja delineado com base nos princípios da $\mathrm{AC}$, devido às particularidades do contexto, observamos a prática de alguns procedimentos comuns a metodologias de ensino mais tradicionais, tais como alinhamento das cadeiras, aulas ministradas em português e no formato do paradigma PPP (apresentação, prática e produção) e realização de exercícios e atividades individuais.

O número médio por turma é de 18 alunos e, teoricamente, todos os aprendizes de uma sala estão no mesmo nível, ou seja, as salas não são multiseriadas. Por se tratar de uma disciplina regular do currículo, o andamento das aulas segue obrigatoriamente o cronograma anual definido pela escola.

\subsubsection{O perfil dos aprendizes e da professora}

A escolha da sala foi definida com base em quatro critérios: ser uma turma do EFII, com mais de uma sala, composta por aprendizes com nível linguístico o mais homogêneo possível e dispostos a participar da pesquisa.

Optamos por uma sala do EFII, porque a professora participante, que também é a pesquisadora, era responsável pelas turmas desse segmento. Além disso, consideramos que nosso problema de pesquisa não é pertinente à EI e ao EFI, tendo em vista os objetivos de aprendizagem definidos pela escola para esses segmentos. Dessa forma, a turma do EFII que atendeu a todos os critérios foi o sexto ano.

A faixa etária dos participantes é de 10 e 11 anos. Definimos como GE o $6^{\circ}$ ano A $\left(6^{\circ} \mathrm{A}\right)$ e como $\mathrm{GC}$ o $6^{\circ}$ ano $\mathrm{B}\left(6^{\circ} \mathrm{B}\right)$. Em ambas as salas havia 22 alunos matriculados e todos participaram das aulas do experimento, mas não consideramos os resultados dos que não entregaram o TCLE. Além disso, também excluímos quatro aprendizes que haviam ingressado na Escola X no ano corrente e estavam em processo de adaptação. O número final de participantes efetivos foram 12 alunos do GE e 11 do GC. 
O GE é composto por seis meninos e seis meninas, sendo quatro descendentes de japoneses e oito não-descendentes. Já no GC há sete meninos e quatro meninas, dos quais três são descendentes e oito são não-descendentes. No que se refere ao perfil socioeconômico dos participantes, todos pertencem à classe média-alta.

Quanto ao conhecimento da língua, os participantes aprenderam os silabários hiragana e katakana ao longo do EFI, mas ainda não mostravam total domínio dos mesmos, e estavam iniciando o estudo da língua para fins comunicativos.

Com relação ao envolvimento, os alunos de ambas as salas participavam ativamente das aulas e se envolviam nas atividades propostas, alguns em maior grau que outros, demonstrando gostarem da LJ. Mantinham um bom relacionamento com a professora, mas casos isolados de indisciplina ocorriam esporadicamente, nada fora da normalidade do contexto e da faixa etária. O quadro 5 apresenta um resumo das turmas e o quadro 6 um resumo dos participantes:

Quadro 5 - Perfil das turmas do $6^{\circ}$ ano de 2014

\begin{tabular}{|c|c|l|l|l|l|}
\hline Turmas & Matriculados & \multicolumn{2}{|c|}{ Sexo } & \multicolumn{2}{c|}{ Ascendência japonesa } \\
\hline \multirow{2}{*}{$6^{\circ} \mathrm{A}-\mathrm{GE}$} & \multirow{2}{*}{22} & Feminino & 10 & Descendente & 06 \\
\cline { 3 - 6 } & & Masculino & 12 & Não-descendente & 16 \\
\hline \multirow{2}{*}{$6^{\circ} \mathrm{B}-\mathrm{GC}$} & 22 & Feminino & 09 & Descendente & 05 \\
\cline { 3 - 6 } & & Masculino & 13 & Não-descendente & 17 \\
\hline
\end{tabular}

Quadro 6 - Perfil dos alunos participantes

\begin{tabular}{|c|c|l|l|l|l|}
\hline Turmas & Participantes & \multicolumn{2}{|c|}{ Sexo } & \multicolumn{2}{c|}{ Ascendência japonesa } \\
\hline \multirow{2}{*}{$6^{\circ} \mathrm{A}-\mathrm{GE}$} & \multirow{2}{*}{12} & Feminino & 06 & Descendente & 05 \\
\cline { 3 - 6 } & & Masculino & 06 & Não-descendente & 07 \\
\hline \multirow{2}{*}{$6^{\circ} \mathrm{B}-\mathrm{GC}$} & \multirow{2}{*}{11} & Feminino & 04 & Descendente & 05 \\
\cline { 3 - 6 } & & Masculino & 07 & Não-descendente & 06 \\
\hline
\end{tabular}

Sobre a professora, como já mencionado, trata-se da pesquisadora responsável por esta pesquisa. Formou-se em Letras - Licenciatura Português/Japonês pela Universidade Estadual Paulista - Campus de Assis, onde começou a estudar a língua. Durante a graduação fez um ano de intercâmbio em uma universidade japonesa. Na época da execução do experimento tinha 27 anos, nove de estudo da LJ e quatro anos de experiência como 
professora dessa língua, todos vividos na escola desta pesquisa. Possuía o certificado nível 2, o penúltimo, do Exame de Proficiência de Língua Japonesa (JLPT). Não é descendente de japoneses, descreve-se como uma professora que gosta muito de sua profissão e que é comprometida e envolvida com o processo de aprendizagem de seus aprendizes, razão pela qual busca sempre se aperfeiçoar e se manter atualizada. Ministrou as aulas do experimento tanto no GE quanto no GC.

Ao escolhermos os participantes do experimento buscamos anular os efeitos das seguintes variáveis externas: diferença no número de participantes, no nível de conhecimento da LJ, no perfil (sexo, descendência e idade) e no histórico de aprendizagem. Outro fator que assegura a validade do experimento é o fato de a professora do GE e do GC ser a mesma pessoa. Além disso, por se tratar da própria pesquisadora, tem-se uma garantia maior de que todas as orientações para a realização das intervenções do GE foram respeitadas.

\subsubsection{O material em uso}

Nessa escola, a partir do EFII utiliza-se o material didático Marugoto - Nihon no Kotoba to Bunka, o qual foi mantido durante o experimento. O GC recebeu aulas sem qualquer tipo de alteração, mantendo todos os elementos do contexto pedagógico em vigor e o GE recebeu quatro intervenções em sua rotina orientadas pela AL. Desse modo, consideramos relevante descrever o material em uso, para que fiquem claras as mudanças ocasionadas pelas intervenções, as quais descrevemos na subseção 3.2.4.

O material didático em questão foi elaborado e testado pela Fundação Japão, organização vinculada ao Ministério das Relações Exteriores do Japão que atua na promoção de intercâmbio cultural e da compreensão mútua entre o Japão e outros países. Trata-se de uma série de livros dividida conforme os níveis de proficiência (A1, A2, B1, B2, C1 e C2) propostos pelo documento JF Standard for Japanese Language Education (JAPAN FOUNDATION, 2010), doravante $J F$ Standard. O material também inclui um site de apoio com atividades dos conteúdos abordados nos livros e um material complementar denominado goichô (agenda de vocabulário). Impresso em tamanho A4, é colorido e o número total de folhas variam conforme o volume. Na Escola X, os materiais adicionais não eram utilizados durante as aulas.

O público alvo são aprendizes de LJ como LE com faixa etária a partir de 18 anos. Embora o livro não seja indicado para a idade dos aprendizes da Escola X, de acordo com a 
coordenação pedagógica, as professoras realizam adaptações para atender às especificidades do público. A escola optou por esse material pelos seguintes motivos: a) acessibilidade - está disponível no Brasil com custo razoável; b) foi elaborado a partir de uma perspectiva de ensino comunicativa; c) aborda questões culturais; d) possui um layout atraente. A seguir descrevemos apenas os livros em uso no $6^{\circ} \mathrm{A} / \mathrm{B}$, os do nível A1.

O nível A1 é abordado em dois livros separados. Os interessados em aprender a língua para se comunicar oralmente podem optar pela edição Katsudô - A1, doravante Katsudô. Para aqueles que desejam estudar os aspectos estruturais da língua é recomendada a edição Rikai A1, doravante Rikai. Segundo Kijima, Tomoyo e Hatta (2012):

\begin{abstract}
A edição Katsudô é focada em atividades linguísticas comunicativas. Aprendem-se eventos relacionados à cultura e formas da língua japonesa características de cada situação ou propósito visando à aquisição de uma linguagem mais natural. $\mathrm{O}$ objetivo é tornar-se capaz de se comunicar ouvindo e falando de fato a língua japonesa. Por outro lado, a edição Rikai é centrada especialmente na aprendizagem de aspectos da competência linguística para a comunicação (letras, vocabulário, gramática, padrões de frases). Embora o foco sejam os aspectos estruturais da língua, é composta por atividades de sala de aula que utilizam ativamente as quatro habilidades, visto que o objetivo é a comunicação (p.109 - tradução nossa) ${ }^{79}$.
\end{abstract}

Dessa forma, esse material visa direcionar o foco da aprendizagem de acordo com os objetivos de estudo do aprendiz. Também é possível adotar as duas edições consecutivamente ou ao mesmo tempo, uma vez que a ordem dos tópicos, lições e conteúdo são iguais nos dois livros. Na Escola X, ambos são utilizados simultaneamente, tendo em vista que o objetivo do segmento é desenvolver igualmente as quatro habilidades linguísticas para a comunicação.

Sobre a organização interna dos livros, os mesmos são divididos em nove tópicos trabalhados em duas lições, totalizando 18 lições por livro. Cada lição é segmentada em seções, sendo de duas a quatro na edição Katsudô e de quatro a seis na Rikai. No livro Katsudô, as seções são intituladas com expressões ou frases que representam o $c a n-d o^{80} \mathrm{em}$ estudo. Já na edição Rikai, correspondem às atividades linguísticas ou aspectos da língua, sendo eles: moji to kotoba (letras e palavras), kaiwa to bunpô (diálogo e gramática), dokkai (leitura) e sakubun (redação).

\footnotetext{
79 活動編はコミュニケーション言語活動を中心に学ぶ教材。場面や目的にあった自然な日本語の使 い方と日本の文化に関する事象を学ぶ。日本語を実際に聞いたり話したりしながら、日本語でコミ ユニケーションができるようになることを目指している。一方、理解編はコミュニケーション言語 能力のうち特に言語構造能力 ( 文字、語彙、文法、文型) の学習を中心にしたもの。言語構造能力 中心と言っても、コミュニケーションを最終目的とするので、4技能を積極的に使った教室活動で 構成されている。

${ }^{80}$ Conjunto de frases descritivas do que o aprendiz deve conseguir realizar usando a língua japonesa em cada um dos seis níveis de proficiência. Essas frases foram chamadas de can-do.
} 
A edição Katsudô traz uma seção diferenciada ao final de cada tópico denominada Seikatsu to bunka (vida cotidiana e cultura), espaço destinado exclusivamente a diálogos sobre a cultura japonesa. Pretende-se, por meio da comparação entre as culturas dos aprendizes e a japonesa promover reflexões sobre as diferenças e trazer à tona as semelhanças, visando o respeito mútuo pela cultura do outro.

Os conteúdos das lições foram definidos de acordo com os can-do propostos pelo $J F$ Standart. Isto é, nos livros A1 são contemplados conteúdos pertinentes às tarefas desse nível de proficiência. O JF Standart não determina quais são os pontos gramaticais a serem trabalhados em cada nível, apenas as tarefas que os aprendizes devem conseguir fazer. Fica a cargo do utilizador determinar quais pontos gramaticais, expressões e vocabulário são adequados a cada can-do. Dessa maneira, o material Marugoto não se baseia nos critérios "grau de dificuldade" e "progressão gramatical" para determinar a ordem de apresentação dos conteúdos. Contudo, o nível de dificuldade desses é condizente com a realidade linguística dos aprendizes, pois as formas selecionadas para se cumprir o objetivo expresso pelo can-do se adequam ao grau de dificuldade correspondente a cada nível.

No que se refere à seleção dos itens lexicais, a edição Katsudô é composta por 545 palavras e a edição Rikai apresenta 568. Dada a predominância de unidades lexicais de uso recorrente, observamos que o critério de índice de frequência foi adotado na escolha do vocabulário em ambas as edições.

O vocabulário está organizado semanticamente por campos nocionais e semânticos. As unidades lexicais foram escolhidas de acordo com os can-do de cada lição. A maior parte das unidades lexicais são amplamente usadas em gêneros textuais informais, em conformidade com o tipo de linguagem - oral informal - predominante nos livros. Observa-se a presença de um número expressivo de itens lexicais de tipos diversificados, tais como colocações (shawâ o abiru - tomar banho), expressões (ojama shimasu - desculpa o incômodo) e orações prontas de uso corrente (itsuga ii desu ka - quando é bom?).

Todas as lições do livro Marugoto iniciam-se com a apresentação do vocabulário, o qual é exposto na primeira página de cada lição, particularmente as palavras de alto teor semântico (substantivos, verbos e adjetivos). Palavras mais gramaticalizadas e expressões são introduzidas nas demais páginas de forma dispersa. Todas as unidades lexicais são expostas na companhia de outra (colocações), como parte de uma expressão semifixa ou em campos semânticos. O sistema de escrita utilizado é o kana (hiragana e katakana), com a transliteração em letras romanas para facilitar a leitura aos aprendizes desse nível. A média de palavras novas por lição é de 30 unidades lexicais. 
Apenas os comandos das atividades são traduzidos em inglês e por isso a prática da inferência é estimulada desde o início. O aprendiz deduz o significado das novas palavras a partir do contexto ou de imagens fornecidas.

Com relação às atividades de vocabulário presentes nas edições, dividimo-las em duas categorias: introdução de vocabulário e fixação/uso. Na edição Katsudô, as atividades de introdução de vocabulário são as primeiras de cada seção. Embora haja uma variação no formato, sempre envolve a audição. Os aspectos da forma, significado e uso são trabalhados, mas apenas no nível do conhecimento receptivo, não há atividades nessa edição que contemplem a escrita ou a produção oral espontânea.

As atividades de fixação/uso aparecem ao longo de cada seção. São atividades realizadas em pares ou grupos que simulam situações de conversação. $O$ aprendiz basicamente troca as informações de um diálogo modelo de acordo com o que deseja comunicar. Dessa forma, não se trata de produção espontânea, o nível de conhecimento ainda é o receptivo. A partir da lição cinco, as atividades de fixação/uso começam a ordenar o nível de conhecimento produtivo. Por exemplo, nas lições sete e dez é solicitada a escrita de pequenos textos (e-mail e cartão de aniversário); e nas lições cinco, onze e dezoito o preenchimento de enquetes e questionários.

Na edição Rikai, as atividades de vocabulário são agrupadas na seção moji to kotoba e enfatizam a forma e o significado da palavra.

A atividade de introdução mais frequente é relacionar palavras com suas imagens correspondentes. Também há atividades de associação de antônimos, formação de colocações, construção de palavras a partir de regras de sufixação, enquadramento de palavras em grupos semânticos e de completar lacunas. Faz-se as correções por meio de áudio e dessa maneira os aprendizes têm acesso às formas escrita e oral. Os aspectos do significado e do uso são abordados de maneira bem pontual e no nível de conhecimento receptivo.

As demais atividades de vocabulário são de fixação/uso e com enfoque na forma da palavra. Explora-se a ortografia em atividades que requerem a identificação da unidade lexical grafada de maneira correta em hiragana ou katakana; a escrita, ao solicitar escrever uma palavra ditada usando os sistemas de escrita da LJ. Essa atividade especificamente aciona conhecimento produtivo, uma vez que o aprendiz precisa decidir qual sistema usar, recordar as letras e escrevê-las.

Por fim, vale mencionar que não há espaço destinado à aprendizagem dos sistemas de escrita da LJ nos livros do nível A1. O aluno é frequentemente exposto aos sistemas hiragana e katakana, mas com o auxílio da transliteração. A partir da lição cinco da versão Rikai, 
alguns kanji são introduzidos apenas para leitura., pois não há nenhum tipo de explicação quanto à forma de escrevê-los. A aprendizagem dos sistemas de escrita fica a cargo do professor ou do aprendiz.

O material didático Marugoto compartilha de parte dos procedimentos metodológicos sugeridos pela AL para o ensino de LE, tais como ênfase nas habilidades receptivas nos níveis iniciais, em especial a compreensão auditiva; tratar o erro como parte do processo, corrigindoo pela reformulação e valorizar o significado da mensagem ao invés da forma. O elemento inédito da $\mathrm{AL}$ é a inserção de princípios lexicais no planejamento dos vários elementos que compõem o processo global do ensino-aprendizagem de LE, a fim de direcionar a atenção do aprendiz para a formação de chunks da língua e os decorrentes tipos de itens lexicais. Desse modo, as intervenções do experimento abaixo apresentadas se prestam a esse objetivo.

\subsubsection{As intervenções do experimento}

A implementação da AL não exige uma mudança radical a ser operada de uma única vez. Segundo Lewis (1997, p. 3 - tradução nossa):

[...] se apresentada com reflexão e sensibilidade, a sua introdução será quase invisível, envolvendo talvez de 20 a 50 pequenas mudanças em cada aula, cada uma em si banal, mas o efeito cumulativo será o ensino mais eficaz e de aprendizagem mais eficiente. ${ }^{81}$

O material didático em uso na Escola $\mathrm{X}$ compartilha de parte dos procedimentos metodológicos sugeridos pela AL para o ensino de LE. Por essa razão, o número de mudanças se reduz.

Lewis (1997, p.85) enfatiza que para a aplicação efetiva da AL a ênfase deve ser desenvolver nos aprendizes a percepção dos chunks, dos itens lexicais de multipalavras da língua-alvo. Para isso, os professores precisam de um conjunto de princípios de organização que incentivem e orientem os aprendizes a registrarem o vocabulário aprendido após o estudo de um texto ou a realização de exercícios e atividades em cadernos lexicais. De acordo com o autor, "a chave é que o registro preciso - escrito - de léxico novo ajuda a perceber e

\footnotetext{
81 [...] if introduced with thought and sensitivity, its introduction will be almost invisible, involving perhaps 20 or even 50 small changes in every lesson, each in itself unremarkable, but the cumulative effect will be more effective teaching and more efficient learning.
} 
maximiza a chance do insumo se tornar insumo internalizado" 82 (LEWIS, 1997, p.85 tradução nossa).

Com base nisso, definimos quatro intervenções a serem feitas no GE: a) uma aula sobre o conceito de chunks e outra sobre os tipos de itens lexicais; b) exercícios complementares; c) atividades complementares; e d) elaboração de um caderno lexical. As intervenções foram inseridas na rotina normal do GE, ocupando de quinze a vinte minutos das aulas.

\section{As aulas expositivas}

A introdução do conceito de chunks ocorreu nas segunda e terceira aulas do cronograma e a intenção era fazer com que os aprendizes percebessem o léxico a partir dessa nova perspectiva durante toda a sequência didática do experimento. Buscamos conduzir a aula em forma de discussão e provendo exemplos das línguas japonesa e portuguesa. A partir da pergunta central "Como as palavras se organizam em nossa mente?", explicamos o conceito de chunks comparando a relação entre as palavras com a relação entre as pessoas, com base na metáfora proposta por Lewis (1997, p.27): “o paralelo entre as parcerias de palavras e as relações humanas proveem uma poderosa e reveladora metáfora. Nossos relacionamentos humanos diferem e em diferentes formas, o mesmo se aplica às parcerias entre as palavras".

Posto isso, apresentamos dois exemplos de combinações de palavras (colocações) da LP. Mostramos duas imagens de pessoas (Anexo B) e solicitamos aos alunos escreverem uma descrição curta do que elas estavam fazendo. Posteriormente, todos comparam suas respostas e, com relação à primeira imagem, duas descrições surgiram: "tomando sorvete" e "chupando sorvete". Referente à segunda surgiu apenas uma, com uma pequena variação: "olhando pela janela" e "olhando a janela". Os alunos perceberam que, embora pudessem optar por "comer sorvete" ou, no segundo caso, "observar pela janela" e "ver pela janela" todos da turma escolheram as formas descritas acima, mostrando que a frequência de coocorrência entre essas palavras é maior, portanto possuem uma forte relação.

Nesse momento, introduzimos o conceito de chunks. Explicamos que muitas palavras aparecem frequentemente juntas e por essa razão são armazenadas em pequenos blocos em nossa mente. Por isso, quando estamos estudando uma LE, no nosso caso a LJ, é importante

\footnotetext{
82 The key is that accurate recording - writing - of new lexis aids noticing and maximises the chance of input becoming intake.
} 
sempre procurarmos saber quais são as combinações possíveis da palavra nova com outras palavras, visando formar pequenos blocos, uma vez que esse processo facilita quando precisamos resgatá-las para comunicar algo.

Além disso, também salientamos que ao aprendermos as palavras dessa forma, evitamos fazer combinações não usuais incorrendo em uma linguagem mais natural. Ilustramos com o exemplo basu ni noru (embarcar no ônibus). Em português, é mais comum falarmos "pegar um ônibus", consequentemente ao buscarmos o equivalente em LJ temos a tendência de resgatar algum verbo que tenha o sentido de "pegar" para produzir o enunciado. O mesmo poderia ocorrer com o exemplo do "tomar sorvete". Ao buscarmos um equivalente em japonês, dificilmente optaríamos pela forma comumente utilizada, aisukurîmu o taberu (comer sorvete), devido à influência de nossa língua. Dessa forma, evidenciamos que um enunciado pode estar gramaticalmente correto, mas ser inadequado.

Finalizamos a primeira aula solicitando aos alunos ficarem atentos às combinações entre as palavras, buscando sempre evitar registrá-las isoladamente, seja mentalmente ou escrevendo.

$\mathrm{Na}$ segunda parte da primeira intervenção, ocorrida na aula três do cronograma, abordamos os tipos de itens lexicais. Explicamos que os blocos de palavras que armazenamos em nosso léxico mental são de tipos diferentes. Com isso, apresentamos os quatro tipos de itens lexicais propostos pela AL com os seguintes exemplos em japonês e português:

\section{Quadro 7 - Exemplos de itens lexicais em japonês e português}

\begin{tabular}{|c|c|c|}
\hline Item lexical & Explicação dada & Exemplos \\
\hline \multirow{2}{*}{ Palavras } & \multirow{2}{*}{$\begin{array}{l}\text { Palavras que expressam sentido } \\
\text { completo por si só. }\end{array}$} & $\begin{array}{l}\text { Casa, professor, escola, } \\
\text { supermercado, água, etc. }\end{array}$ \\
\hline & & $\begin{array}{l}\text { Nihon (Japão), megane (óculos), } \\
\text { hon (livro), densha (trem), etc. }\end{array}$ \\
\hline \multirow[b]{2}{*}{ Polipalavra } & \multirow{2}{*}{$\begin{array}{l}\text { Palavra composta por duas ou mais } \\
\text { palavras. Não podem ser separadas, } \\
\text { caso contrário perdem o sentido } \\
\text { original da palavra que formaram } \\
\text { ao se juntarem. }\end{array}$} & $\begin{array}{l}\text { Abaixo-assinado } \\
\text { Dente de leite } \\
\text { Água de coco } \\
\text { Baixo-astral } \\
\text { Controle remoto }\end{array}$ \\
\hline & & $\begin{array}{l}\text { Natsu yasumi (férias de verão) } \\
\text { Denwa bangô (número de } \\
\text { telefone) } \\
\text { Keitai denwa (celular) } \\
\text { Kankô ryokô (viagem de } \\
\text { turismo) } \\
\text { Yuki daruma (boneco de neve) }\end{array}$ \\
\hline
\end{tabular}


Continuação do quadro 7 - Exemplos de itens lexicais em japonês e português

\begin{tabular}{|c|c|c|}
\hline \multirow[b]{2}{*}{ Colocações } & \multirow{2}{*}{$\begin{array}{l}\text { Combinações de palavras que } \\
\text { ocorrem com maior frequência do } \\
\text { que o acaso. São combinações mais } \\
\text { comuns dentro de um leque de } \\
\text { opções, ou combinações } \\
\text { socialmente aceitas. Por exemplo: } \\
\text { "cometer um crime" é mais usado } \\
\text { do que "fazer um crime" ou } \\
\text { "praticar um crime"; "Tem horas?" } \\
\text { é uma forma socialmente aceita } \\
\text { para perguntar as horas. Essas } \\
\text { combinações podem ser fixas ou } \\
\text { semifixas. }\end{array}$} & $\begin{array}{l}\text { Redondamente enganada } \\
\text { Cometer um crime } \\
\text { Prestação de contas } \\
\text { Correr perigo } \\
\text { Vir à tona }\end{array}$ \\
\hline & & $\begin{array}{l}\text { Kimochi ga ii (sensação gostosa) } \\
\text { Uchi ni kaeru (voltar para casa) } \\
\text { Denwa o kakeru (telefonar) } \\
\text { Te o tsunagu (dar as mãos) } \\
\text { Me ga sameru (despertar) }\end{array}$ \\
\hline \multirow[b]{2}{*}{$\begin{array}{l}\text { Expressões } \\
\text { institucionalizadas }\end{array}$} & \multirow[b]{2}{*}{$\begin{array}{l}\text { Frase prontas frequentemente } \\
\text { usadas em situações específicas. } \\
\text { Podem ser fixas ou semifixas. }\end{array}$} & $\begin{array}{l}\text { Tudo bem? } \\
\text { Quanto custa? } \\
\text { Bom dia } \\
\text { Que horas são? } \\
\text { Onde é ...? } \\
\end{array}$ \\
\hline & & $\begin{array}{l}\text { Onamae wa? } \\
\text { (Qual seu nome?) } \\
\text { Dochirakara desuka } \\
\text { (De onde você veio?) } \\
\text { Itsudemo ii desuka } \\
\text { (Qualquer hora está bom) } \\
\text { Ki o tsukete } \\
\text { (Cuide-se) }\end{array}$ \\
\hline
\end{tabular}

Distinguir um tipo de item lexical do outro é um trabalho com certo grau de dificuldade, por isso não esperávamos que no curto período de tempo do experimento os alunos conseguissem diferenciá-los com precisão. Os objetivos principais da primeira intervenção foi despertar a atenção dos alunos com relação à formação de chunks e levá-los a registrar as palavras novas sempre em parceria com outra. Antes de finalizar a aula, solicitamos aos alunos formarem duplas e procurarem nas lições anteriores dos livros os tipos de itens lexicais apresentados.

\section{Os exercícios}

A segunda intervenção foram os exercícios complementares realizados em três das 12 aulas do experimento. Lewis (1997, p.89) define exercício como uma atividade pedagógica 
reflexiva comumente realizada individualmente, geralmente escrita e com foco exclusivamente linguístico.

A palavra chave da AL é "perceber". Todos os esforços, inclusive os exercícios, devem ser planejados de maneira a levar os aprendizes a notarem as parcerias estabelecidas entre as palavras. Por se tratar de uma atividade reflexiva e que direciona a atenção do aprendiz, o autor considera que os exercícios, quando elaborados de acordo com princípios lexicais, e não gramaticais, podem auxiliar na aprendizagem e organização do léxico mental em chunks.

Em seu livro Implementing the lexical approach: putting theory into practice, Lewis (1997) elenca seis categorias básicas de exercícios: identificar, deletar, sequenciar, categorizar, completar e relacionar. De acordo com o autor, esses não são inéditos, mas se diferenciam quando elaborados com foco lexical cuidadosamente selecionado.

Por uma questão de limitação de tempo, escolhemos apenas três tipos para compor o conjunto de intervenções do experimento, sendo eles: completar lacunas de um diálogo, relacionar colunas de palavras que formam itens lexicais de multipalavras e deletar palavras que não formam parcerias usuais. Todos os exercícios são curtos, para serem realizados em pouco tempo e se ajustarem ao cronograma das aulas, e abordam apenas itens lexicais já conhecidos e os novos presentes nas lições 13 e 14 . Tendo em vista que muitos dos aprendizes ainda apresentavam dificuldade em ler e escrever com os sistemas de escrita hiragana e katakana, optamos por utilizar também a transliteração, ou seja, todos os exercícios são apresentados em duas versões.

A elaboração do exercício de completar (Apêndice D) foi norteado por duas orientações básicas. A primeira, de não deixar em branco o espaço referente à palavra que indica o tópico da oração, ou seja, a parte que contém a informação já conhecida pelos interlocutores, salvo nos casos de expressões institucionalizadas ou colocações fixas. A razão disso é evitar um exercício que privilegia a adivinhação ao invés da interpretação, uma vez que predizer a informação nova de uma mensagem só é possível quando temos informação prévia já conhecida. A outra orientação dada é assegurar que os espaços em branco sejam partes de parcerias de palavras relativamente fixas, tais como polipalavras, colocações e expressões fixas ou semifixas (LEWIS, 1997, p.89). Dessa forma, elegemos as expressões “........ga ii desu" e “........desu kara" para serem completadas com unidades lexicais adequadas ao contexto do diálogo. Não oferecemos opções para o preenchimento, orientamos limitar a escolha ao vocabulário das lições em estudo. 
Já para a elaboração do exercício de relacionar (Apêndice E), as orientações seguidas foram usar parcerias de palavras as mais fixas possíveis; ordenar os itens do mais fácil para mais provável de ser confundido; não colocar muitas combinações para serem relacionadas de uma única vez; se possível, escolher pares que destaquem diferenças (LEWIS, 1997, p.89). Nesse exercício, usamos as polipalavras takushî noriba e basu tei e as colocações semifixas benri desukara, minami guchi, eki de orimasu, chikatetsu ni norimasu.

O exercício de deletar (Apêndice F), de acordo com Lewis (1997, p.91), faz com que os aprendizes reflitam sobre as parcerias não usuais da língua-alvo, muitas vezes produzidas por influência da L1.

\title{
As atividades
}

A terceira intervenção foram as atividades complementares realizadas em três das 12 aulas. Assim como os exercícios, também devem ser delineadas tendo em mente direcionar a atenção do aprendiz para a formação de chunks. Lewis afirma que:

\begin{abstract}
A AL não representa uma revolução. Ela fornece princípios para repensar muitas atividades e técnicas familiares e uma nova maneira de olhar para o conteúdo dos cursos. Como Henry Widdowson observou, se você afirma que seu ensino é eclético, e não pode afirmar os princípios de seu ecletismo, você não é eclético, apenas meramente confuso. Muitas das atividades neste capítulo serão bem conhecidas pelos professores. O que pode ser novo é a consistente atenção para garantir que cada atividade tenha um foco lexical cuidadosamente selecionado. Muitas outras técnicas e atividades podem facilmente ser adaptadas de forma semelhante para lhes dar um foco lexical. A leitura de quebra-cabeças, em que um texto é cortado em pedaços e a tarefa dos alunos é reconstruí-lo, é um exemplo simples: o que a $\mathrm{AL}$ fornece é uma maneira de decidir onde as quebras devem ser feitas (1997, p.108 tradução nossa). ${ }^{83}$
\end{abstract}

A primeira atividade (Apêndice G) foi um jogo de cartas. Organizamos os alunos em grupos de quatro e distribuímos igualmente 52 cartas que continham partes de colocações livres e polipalavras. No início do jogo, cada um colocou uma carta sob a mesa. O objetivo era formar as combinações de palavras entre essas cartas e as cartas da mão. $\mathrm{O}$ vencedor era

\footnotetext{
${ }^{83}$ The Lexical Approach does not represent a revolution. It provides principles for re-thinking many familiar activities and techniques, and a new way of looking at the content of courses. As Henry Widdowson has observed, if you claim your teaching is eclectic, and you cannot state the principles of your eclecticism, you are not eclectic, merely confused. Many of the Activities in this chapter will be well-known to teachers already; what may be new is the consistent attention to ensuring each Activity has a carefully selected lexical focus. Many other techniques and activities can easily be similarly adapted to give them a lexical focus. Jigsaw reading, where a text is chopped into pieces and the students' task is to re-construct it, is a simple example: what the Lexical Approach provides is a principled way of deciding where the breaks should be made.
} 
quem conseguisse formar mais combinações ao fim de dez minutos. Essa atividade exigiu dos aprendizes atenção e reflexão sobre os itens lexicais tanto para realizar as combinações quanto para julgar se a combinação apresentada pelo colega é válida. Ao final de cada rodada, a professora-pesquisadora tirou fotos das cadeias de combinações resultantes para posterior discussão e correção em grupo.

$\mathrm{Na}$ segunda atividade (Apêndice $\mathrm{H}$ ), os alunos formaram duplas e localizaram chunks em um texto. Solicitamos pintar de azul as combinações de palavras recorrentes (colocações e poliplavras) e de amarelo as expressões institucionalizadas fixas e semifixas. Em seguida, os grupos compararam entre si as marcações feitas e discutiram as diferenças. Com relação ao foco lexical dessa atividade, Lewis afirma:

\footnotetext{
O foco é autoevidente, mas note que esta atividade também se destina a ajudá-lo a ver o que os alunos consideram chunks. Se eles estão olhando para o texto de maneira equivocada, seus 'erros' fornecem feedback essencial. A tarefa deve ser apresentada sob esta luz - como uma maneira de explorar o texto em conjunto - e não como 'você faz um exercício e eu vou te mostrar a resposta correta' (1997, p. 109 - tradução nossa). ${ }^{84}$
}

A última atividade (Apêndice I) consistia em discutir uma lista de dez expressões institucionalizadas fixas e semifixas. Em pares, os aprendizes elaboraram respostas para as seguintes perguntas:

1) Em quais situações essas expressões podem ocorrer?

2) Quem poderia dizer essas expressões?

3) O que poderia ter acontecido antes dessas expressões serem faladas?

4) Que tipo de resposta ou reação a cada expressão pode ocorrer?

O professor é orientado a evitar desconsiderar a resposta do aluno e impor outra que considera mais adequada. O indicado é questionar suas razões para determinada escolha e buscar entender seu ponto de vista sobre o uso da língua. Lewis alerta que:

\begin{abstract}
As expressões levantam questões difíceis sobre quais são apropriadas para pessoas de diferentes idades, tanto para homens quanto para mulheres. Ou mesmo se alguma linguagem é inadequada para alunos intermediários, porque seu uso bem-sucedido é dependente de nuances de entoação. Os professores precisam ser sensíveis e usar
\end{abstract}

\footnotetext{
${ }^{84}$ One focus is self-evident, but note that this activity is also intended to help you to see what the learners think are chunks. If they are looking at the text in unhelpful ways, their 'mistakes' provide you with essential feedback. The task should be presented in this light - as a way of exploring the text together - not as 'you do an exercise and I'll show you the correct answer'.
} 
algumas atividades para incentivar a consciência do aluno quanto a fatores que influenciam o efeito que eles criam usando expressões particulares. Os professores devem aconselhar, não ditar. Em última análise, a língua que os alunos adquirem é profundamente pessoal, uma forma importante de mostrar quem são em Inglês. A escolha do que é ou não apropriado é finalmente uma questão para o indivíduo (1997, p.124 - tradução nossa). ${ }^{85}$

\section{O caderno lexical}

A quarta intervenção foi o caderno lexical (Apêndices J e K). É comum entre os aprendizes de uma LE anotar as palavras que aprendem. Alguns são mais sistemáticos e organizam as anotações em cadernos, outros escrevem nas margens dos livros ou em papéis avulsos. No entanto, o caderno lexical proposto pela AL se difere do que já é comumente feito, em virtude dos princípios organizacionais sugeridos para o registro de palavras novas, sendo eles (LEWIS, 1997, p.76):

1) Desencorajar a inclusão de cada nova palavra de maneira avulsa, ou separar uma seção só para esse tipo palavra;

2) Registrar apenas itens que considera úteis e que poderá precisar recuperar em alguma situação de comunicação;

3) O caderno lexical deve ser formatado de maneira a permitir o registro de diferentes tipos de itens lexicais e devem encorajar a estruturação sistemática da linguagem que é registrada;

4) Evitar o registro de itens lexicais simples (uma palavra);

5) Em caso de anotações bilíngues, a ordem deve ser LM para LE no caso do vocabulário produtivo e LE para LM, para registro de vocabulário receptivo;

6) Ao registrar um novo padrão léxico no caderno, tentar conscientemente pensar em outros exemplos semelhantes;

7) O vocabulário novo pode ser coletado em uma aula particular, ou durante um período de tempo. Regularmente, deve-se dispor espaço nas aulas para revisar o

\footnotetext{
${ }^{85}$ Expressions raise difficult questions about which are appropriate for people of different ages, for both men and women, quieter or more forceful personalities, or even whether some language is unsuitable for intermediate learners because its successful use is so dependent on nuances of intonation. Teachers need to be sensitive and to use a few activities to encourage learner awareness of the factors which influence the effect they create by using particular expressions. Teachers must advise, not dictate; ultimately the language learners acquire is deeply personal, an important way of showing who they are in English. The choice of what is or is not suitable is finally a matter for the individual.
} 
que foi registrado, visando garantir a precisão, a utilidade, a organização e a recuperação dos itens lexicais vistos.

Para a AL, o propósito do caderno lexical é promover uma aprendizagem personalizada. O caderno de cada aprendiz deverá conter itens lexicais individualmente escolhidos, além dos que foram registrados por todos da turma (LEWIS, 1997, p.76).

Quanto ao formato, o caderno lexical pode ser páginas impressas com formatação préconcebida que incentive o registro de padrões específicos, ou pode ser um caderno convencional, onde os aprendizes organizam de forma autônoma o registro dos itens lexicais novos, baseados nos princípios organizadores descritos anteriormente (LEWIS, 1997, p.76).

Tendo em vista a faixa etária dos participantes desta pesquisa, optamos pelo primeiro formato. A formatação pré-concebida utilizada está de acordo com as seguintes orientações de Lewis (1997, p.78 - tradução nossa):

Se queremos incentivar os alunos a registrarem pedaços maiores, eles precisam de algo mais do que um livro de vocabulário básico de duas colunas. Em um caderno verdadeiramente lexical, os formatos encorajarão o registro de colocações e expressões completas. São necessários formatos diferentes, projetados para promover o registro mais útil e memorável, adequados a diferentes tipos de padrões léxicos. ${ }^{86}$

As formatações pré-concebidas de nosso caderno lexical foram escolhidas a partir das diversas sugestões oferecidas por Lewis (1997) em seu livro Implementing the lexical approach: putting theory into practice. Os aprendizes receberam dois cadernos lexicais para registrar e organizar o vocabulário novo que surgiu em cada uma das lições estudadas ao longo do experimento. O preenchimento foi feito individualmente e discutido posteriormente em duplas.

Por fim, com relação às intervenções vale mencionar que para identificarmos as colocações e as expressões institucionalizadas presentes no vocabulário das lições 13 e 14 e escolhermos as que seriam apresentadas nas explicações e nos exemplos utilizamos o Balanced Corpus of Contemporary Written Japanese ${ }^{87}$. Além disso, submetemos todo o

\footnotetext{
${ }^{86}$ If we want to encourage learners to record larger chunks, they need something more than a basic two-column vocabulary book. In a truly lexical Notebook, Formats will encourage the recording of complete Collocations and Expressions. Different formats, designed to promote the most helpful and memorable record and suited to different kinds of lexical patterns, are needed.

${ }^{87}$ Trata-se de um corpus da língua japonesa contemporânea desenvolvido pelo Instituto Nacional da Língua Japonesa. É composto por uma amostra de 100 milhões de palavras, das quais $35 \%$ são amostragem aleatória de unidades lexicais extraídas de livros, revistas e jornais publicados nos anos de 2001-2005; 30\% são de livros registrados nas bibliotecas públicas de Tóquio e publicados durante os anos de 1985-2005; 35\% são palavras colhidas aleatoriamente de vários minis corpus, tais como textos governamentais, livros didáticos da educação
} 
material utilizado durante o experimento à duas estagiárias japonesas que estavam na Escola X no período do experimento.

\subsubsection{As palavras-alvo}

As palavras-alvo foram escolhidas a partir do vocabulário das lições 13 e 14 - Tópico sete denominado Machi (cidade) - das edições Katsudô e Rikai do material didático Marugoto A1. O número total de unidades lexicais novas introduzidas nessas lições é 97. Após análise, excluímos as que já haviam sido ensinadas em anos anteriores e realizamos um pré-teste utilizando uma versão modificada do VKS (Anexo C) com 50 itens, sendo 10 distratores e 40 candidatas a serem confirmadas como palavras desconhecidas pelos aprendizes. Dentre essas, escolhermos as que não foram reconhecidas e atenderam à três outros critérios, sendo eles:

1) Dos tipos de itens lexicais, optamos por avaliar a aprendizagem de palavras lexicalizadas simples dado o nível de competência linguística dos aprendizes. Essas palavras aparecem como partes de itens lexicais de multipalavras ao longo do experimento, mas não visaremos esse conhecimento específico nos testes. No entanto, como utilizaremos testes em formato de escala com níveis de reconhecimento e produção, haverá espaço para demonstrar esse conhecimento;

2) Escolhemos propositalmente palavras de categorias gramaticais diferentes para verificarmos a ação das intervenções em todos os tipos de unidade lexicais;

3) Visando garantir um número mínimo de exposições aos aprendizes, elegemos as palavras que se repetem ao menos três vezes ao longo das lições 13 e 14 . O GE, em função das atividades extras decorrentes das intervenções, foi exposto mais vezes às palavras-alvo.

Por fim, as dez palavras-alvo selecionadas para o experimento foram:

\section{Quadro 8 - Palavras-alvo selecionadas}

\begin{tabular}{|l|l|l|}
\hline Palavra & Tradução & Classe gramatical \\
\hline Norimasu & Embarcar & Verbo \\
\hline Orimasu & Desembarcar & Verbo \\
\hline
\end{tabular}

básica, textos da internet, entre outros (MAEKAWA, 2007). Dentre as várias informações que esse corpus oferece, interessa-nos as relacionadas à frequência de uso das palavras, o contexto linguístico e a coocorrência da palavra com outras (colocações). 


\section{Continuação do quadro 8 - Palavras-alvo selecionadas}

\begin{tabular}{|l|l|l|}
\hline Tôi & Longe & Adjetivo \\
\hline Chikai & Perto & Adjetivo \\
\hline Yûmei & Famoso & Adjetivo \\
\hline Benri & Prático & Adjetivo \\
\hline Chizu & Mapa & Substantivo \\
\hline Kûkô & Avião & Substantivo \\
\hline Massugu & Direto, reto & Advérbio \\
\hline Dôyatte & Como & $\begin{array}{l}\text { Pronome } \\
\text { Interrogativo }\end{array}$ \\
\hline
\end{tabular}

O número reduzido de dez palavras-alvo se deve à limitação do tempo disponível para a execução dos testes e à tentativa de evitar o comprometimento dos resultados em função de desconforto ou desinteresse por parte dos participantes em responder um teste longo.

\subsubsection{O cronograma e o planejamento simplificado das aulas}

As aulas do experimento ocorreram no período de 22 de outubro a 07 de novembro de 2014. O pré-teste para definição das palavras-alvo foi realizado no dia 20 de outubro, o pósteste imediato (PTI) na aula seguinte ao final da sequência didática e o pós-teste postergado (PTP) um mês depois.

O GE teve 12 aulas e o GC teve nove, com duração de 50 minutos cada. A diferença no número de aulas entre os grupos se deve às intervenções realizadas no GE, as quais ocuparam de 15 a 20 minutos de cada aula.

O horário regular das aulas de LJ são três por semana, mas durante o experimento os dois grupos tiveram aulas todos os dias. Isso foi possível graças às trocas de aulas com professores de outras disciplinas.

A Escola $\mathrm{X}$ autorizou o desenvolvimento do experimento e a coleta de dados em um período específico (outubro a dezembro), meses com menos eventos escolares. Por essa razão, não realizamos o experimento apenas durante o horário das aulas regulares para concluirmos dentro do período cedido pela instituição. 
Ao longo do experimento, todos os participantes que entregaram o TCLE compareceram em todas as aulas. O cronograma abaixo descreve a data, o horário, o conteúdo regular e a atividade complementar de todas as aulas da sequência didática do GE:

Quadro 9 - Cronograma do Experimento - GE (6 $\left.{ }^{\circ} \mathrm{A}\right)$

\begin{tabular}{|c|c|c|c|}
\hline Data & Horário & Atividade Base & Atividade Complementar \\
\hline $24 / 10$ & $12 \mathrm{~h} 00$ & $\begin{array}{l}\text { Livro: Marugoto Katsudô } \\
\text { Lição: } 13 \\
\text { Páginas: } 83,84 \text { e } 85\end{array}$ & $\begin{array}{l}\text { - Explicação sobre a pesquisa; } \\
\text { - Entrega do TCLE; }\end{array}$ \\
\hline $27 / 10$ & $12 \mathrm{~h} 00$ & $\begin{array}{l}\text { Livro: Marugoto Katsudô } \\
\text { Lição: } 13 \\
\text { Páginas: } 86 \text { e } 87\end{array}$ & $\begin{array}{l}\text { Introdução do conceito de } \\
\text { chunks. }\end{array}$ \\
\hline $28 / 10$ & $15 \mathrm{~h} 00$ & $\begin{array}{l}\text { Livro: Marugoto Rikai } \\
\text { Lição: } 13 \\
\text { Páginas: } 118 \text { a } 119\end{array}$ & $\begin{array}{l}\text { Introdução aos tipos de itens } \\
\text { lexicais: palavras, polipalavras, } \\
\text { colocações e expressões fixas e } \\
\text { semifixas. }\end{array}$ \\
\hline $29 / 10$ & $10 \mathrm{~h} 20$ & $\begin{array}{l}\text { Livro: Marugoto Rikai } \\
\text { Lição: } 13 \\
\text { Páginas: } 120 \text { a } 121\end{array}$ & $\begin{array}{l}\text { Exercício I } \\
\text { Exercício II }\end{array}$ \\
\hline $30 / 10$ & $15 \mathrm{~h} 00$ & $\begin{array}{l}\text { Livro: Marugoto Rikai } \\
\text { Lição: } 13 \\
\text { Páginas: } 122 \text { a } 123\end{array}$ & $\begin{array}{c}\text { Correção dos exercícios I e II } \\
\text { Atividade I } \\
\text { "Jogo de cartas" }\end{array}$ \\
\hline $31 / 10$ & $10 \mathrm{~h} 20$ & $\begin{array}{l}\text { Livro: Marugoto Rikai } \\
\text { Lição: } 13 \\
\text { Páginas: } 124 \text { e } 125\end{array}$ & $\begin{array}{l}\text { Atividade I - (cont.) } \\
\text { Correção/discussão da } \\
\text { atividade I }\end{array}$ \\
\hline $03 / 11$ & $12 \mathrm{~h} 00$ & $\begin{array}{l}\text { Livro: Marugoto Katsudô } \\
\text { Lição: } 14 \\
\text { Páginas: } 88 \text { a } 89\end{array}$ & $\begin{array}{l}\text { Apresentação e entrega do } \\
\text { caderno lexical L13. }\end{array}$ \\
\hline $04 / 11$ & $10 \mathrm{~h} 20$ & $\begin{array}{l}\text { Livro: Marugoto Katsudô } \\
\text { Lição: } 14 \\
\text { Páginas: } 90 \text { e } 91\end{array}$ & $\begin{array}{c}\text { Exercício III } \\
\text { Correção do exercício III }\end{array}$ \\
\hline $05 / 11$ & $9 \mathrm{~h} 10$ & $\begin{array}{l}\text { Livro: Marugoto Rikai } \\
\text { Lição: } 14 \\
\text { Página: } 126 \text { e } 127\end{array}$ & Atividade II \\
\hline $06 / 11$ & $14 \mathrm{~h} 10$ & $\begin{array}{l}\text { Livro: Marugoto Rikai } \\
\text { Lição: } 14 \\
\text { Páginas: } 128 \text { a } 129\end{array}$ & $\begin{array}{l}\text { Correção/discussão da } \\
\text { atividade II }\end{array}$ \\
\hline $07 / 11$ & $7 \mathrm{~h} 30$ & $\begin{array}{l}\text { Livro: Marugoto Rikai } \\
\text { Lição: } 14 \\
\text { Páginas: } 130 \text { a } 131\end{array}$ & Atividade III \\
\hline $07 / 11$ & & $\begin{array}{l}\text { Livro: Marugoto Rikai } \\
\text { Lição: } 14 \\
\text { Página: } 132\end{array}$ & $\begin{array}{c}\text { Discussão da atividade III } \\
\text { Entrega do caderno lexical } \\
\text { L14. }\end{array}$ \\
\hline $10 / 11$ & $12 \mathrm{~h}$ & \multicolumn{2}{|c|}{ Aplicação de pós-teste imediato. } \\
\hline $08 / 12$ & 9h20 & \multicolumn{2}{|c|}{ Aplicação de pós-teste postergado. } \\
\hline
\end{tabular}


O GC não sofreu nenhuma mudança no planejamento das aulas, como descrito a seguir:

Quadro 10 - Cronograma do experimento - GC (6 $\left.{ }^{\circ} \mathrm{B}\right)$

\begin{tabular}{|c|c|c|c|}
\hline Data & Horário & Atividade Base & Atividade Complementar \\
\hline $22 / 10$ & $7 \mathrm{~h} 30$ & $\begin{array}{l}\text { Livro: Marugoto Katsudô } \\
\text { Lição: } 13 \\
\text { Páginas: } 84 \text { e } 85\end{array}$ & $\begin{array}{l}\text {-Explicação sobre a pesquisa; } \\
\text { - Entrega do TCLE. }\end{array}$ \\
\hline $22 / 10$ & $14 \mathrm{~h} 10$ & $\begin{array}{l}\text { Livro: Marugoto Katsudô } \\
\text { Lição: } 13 \\
\text { Páginas: } 86 \text { e } 87\end{array}$ & - \\
\hline $23 / 10$ & $8 \mathrm{~h} 20$ & $\begin{array}{l}\text { Livro: Marugoto Rikai } \\
\text { Lição: } 13 \\
\text { Páginas: } 118 \text { a } 120\end{array}$ & - \\
\hline $29 / 10$ & $7 \mathrm{~h} 30$ & $\begin{array}{l}\text { Livro: Marugoto Rikai } \\
\text { Lição: } 13 \\
\text { Páginas: } 121 \text { a } 123\end{array}$ & - \\
\hline $29 / 10$ & $14 \mathrm{~h} 10$ & $\begin{array}{l}\text { Livro: Marugoto Rikai } \\
\text { Lição: } 13 \\
\text { Páginas: } 124 \text { a } 125\end{array}$ & - \\
\hline $30 / 10$ & $8 \mathrm{~h} 20$ & $\begin{array}{l}\text { Livro: Marugoto Katsudô } \\
\text { Lição: } 14 \\
\text { Páginas: } 88 \text { e } 89\end{array}$ & - \\
\hline $05 / 11$ & $7 \mathrm{~h} 30$ & $\begin{array}{l}\text { Livro: Marugoto Katsudô } \\
\text { Lição: } 14 \\
\text { Páginas: } 90 \text { a } 92\end{array}$ & - \\
\hline $05 / 11$ & $14 \mathrm{~h} 10$ & $\begin{array}{l}\text { Livro: Marugoto Rikai } \\
\text { Lição: } 14 \\
\text { Páginas: } 126 \text { a } 129\end{array}$ & - \\
\hline $06 / 11$ & $8 \mathrm{~h} 20$ & $\begin{array}{l}\text { Livro: Marugoto Rikai } \\
\text { Lição: } 14 \\
\text { Páginas: } 130 \text { a } 132\end{array}$ & - \\
\hline $10 / 11$ & $11 \mathrm{~h} 10$ & \multicolumn{2}{|c|}{ Aplicação de pós-teste. } \\
\hline $08 / 12$ & $12 \mathrm{~h}$ & \multicolumn{2}{|c|}{ Aplicação de pós-teste postergado. } \\
\hline
\end{tabular}

O plano completo das aulas do GE se encontra nos Apêndice C. O desenvolvimento das aulas do GC é igual ao GE, com exceção das atividades complementares.

\subsection{Instrumento de coleta de dados: Escala de Conhecimento Vocabular (VKS)}

O VKS é um instrumento de avaliação elaborado por Wesche e Paribakht (1993; 1996), com o objetivo de identificar em que estágio do conhecimento sobre as palavras-alvo se 
encontra o aprendiz. Apresenta-se no formato de uma escala de autoavaliação e desempenho e cada palavra é avaliada isoladamente. A escala é composta por cinco níveis que partem do não reconhecimento até a habilidade de uso em sentenças. Os níveis da escala são uma tentativa de refletir os estágios do conhecimento lexical, a fim de verificar o quanto se sabe sobre as palavras em teste (WESCHE; PARIBAKHT, 1997, p.175).

Os dois primeiros níveis da escala correspondem ao conhecimento receptivo e os três últimos ao conhecimento produtivo. Isto é, nos dois primeiros os aprendizes devem apenas reconhecer a palavra-alvo e nos três últimos fornecer informações e empregá-la em uma frase, como podemos ver abaixo (WESCHE; PARIBAKHT, 1997, p.180):

I. Eu não me lembro de ter visto essa palavra antes.

II. Eu já vi essa palavra antes, mas eu não sei o que significa.

III. Eu já vi essa palavra antes, eu acho que significa (sinônimo ou tradução).

IV. Eu conheço essa palavra, ela significa (sinônimo ou tradução).

V. Eu consigo usar em uma sentença (escreva a sentença). (Se vocêfez esse item, por favor faça o item IV também)

Os escores são obtidos tendo como referência uma grade para correção que determina a pontuação de cada resposta de acordo com o conhecimento autorelatado ou demonstrado pelo aprendiz. As respostas fornecidas nas categorias III, IV e V exigem a correção manual dos testes devido à necessidade de julgamento do avaliador, razão pela qual não é um teste de larga escala.

Wesche e Paribakht (1996) afirmam que as categorias I e II são autoavaliativas, ao passo que as categorias III, IV e V representam o conhecimento linguístico demonstrado. As categorias I e II recebem o escores 1 e 2, respectivamente. As categorias III, IV e V podem receber os escores correspondentes ou menores, com exceção do IV, que receberá apenas escores menores, como ilustrado no quadro da página seguinte.

Selecionamos esse teste como instrumento de coleta de dados por considerarmos que seu delineamento atende às necessidades desta pesquisa. Tendo em vista que o processo de aprendizagem de uma nova palavra é gradual e que o objetivo desta investigação é verificar as possíveis contribuições da AL para a aprendizagem do léxico, consideramos necessário adotar uma forma de avaliação que verificasse o quanto o aluno aprendeu sobre cada palavra, e não apenas quantas palavras foram aprendidas. 
Dessa forma, analisaremos os dados obtidos a partir do VKS buscando averiguar se há alguma relação entre o estágio que o aprendiz demonstrou estar e as intervenções elaboradas de acordo com os princípios da AL. O VKS já foi empregado em diversas pesquisas experimentais que também objetivavam verificar a contribuição de determinada proposta pedagógica (abordagens, metodologias ou formas de instrução) para a aprendizagem do léxico (WESCHE; PARIBAKHT, 1996, 1997; JOE, 1998; ZILLES, 2001; PEREIRA, 2006).

\section{Quadro 11 : Atribuição de escores do VKS}

\begin{tabular}{|c|c|c|l|}
\hline $\begin{array}{c}\text { Categorias } \\
\text { autorelatadas }\end{array}$ & $\begin{array}{c}\text { Possiveis } \\
\text { escores }\end{array}$ & \multicolumn{1}{|c|}{ Significado dos escores } \\
\hline I & 1 & A palavra não é familiar. \\
\hline II & 2 & $\begin{array}{l}\text { A palavra é familiar, mas seu significado não é } \\
\text { conhecido. }\end{array}$ \\
\hline III & 3 & Um sinônimo ou uma tradução correta é fornecida. \\
\hline IV & 4 & $\begin{array}{l}\text { A palavra é utilizada com adequação semântica em } \\
\text { uma frase. }\end{array}$ \\
\hline V & 5 & $\begin{array}{l}\text { A palavra é utilizada com adequação semântica e } \\
\text { gramatical em uma frase. }\end{array}$ \\
\hline
\end{tabular}

(WESCHE; PERIBAKHT, 1997, p. 181)

Optamos pelo VKS porque o consideramos adequado e por já ter sido utilizado em pesquisas com objetivos semelhantes ao nosso. Todavia, o teste piloto realizado com alunos aprendizes de outra sala da Escola X, no mês de junho de 2014, revelou a necessidade de adaptações.

$\mathrm{Na}$ fase de elaboração tivemos que decidir qual sistema de escrita utilizar para escrever as palavras-alvo. O silabário hiragana já havia sido ensinado nos anos escolares anteriores e eram utilizados durante as aulas, mas os alunos não apresentavam domínio total desses sistemas de escrita, pois sempre cometiam erros de decodificação. Se o mesmo ocorresse nos testes, poderíamos cometer o equívoco de inferir que não houve nenhum tipo de aprendizagem, uma vez que o aprendiz, mesmo sabendo outras informações, tais como o significado e a forma de uso, ficaria impossibilitado de demonstrar por não ter acessado a palavra em função do não reconhecimento de sua forma escrita. Duas outras questões 
surgiram: a) Consideraremos inadequadas respostas formuladas com o uso do alfabeto romano?; b) Atribuiremos escores menores às respostas com erros decorrentes da confusão entre um fonograma e outro, mesmo sendo possível identificar a palavra escrita?

Mesmo diante das possíveis adversidades, optamos por escrever as palavras utilizando o silabário hiragana. Os aprendizes já haviam estudado esse sistema de escrita, por esse motivo não utilizá-lo poderia ser interpretado como um retrocesso, ou como uma falta de confiança da professora na competência dos aprendizes, causando efeito negativo na autoconfiança dos mesmos. Para evitar os possíveis problemas descritos acima, tomamos as medidas de ler as palavras no momento da explicação de como responder ao teste e permitimos o uso da tabela de leitura do hiragana. Além disso, definimos como critério de correção não penalizar desacertos oriundos da falta de domínio do silabário hiragana, tais como troca de fonogramas e uso do alfabeto romano.

No momento da correção do teste piloto veio à tona um novo problema relacionado com a categoria V da escala, a qual solicita ao aprendiz empregar a palavra em uma frase. A orientação dada ao aplicador é atribuir o escore máximo se houver acuidade gramatical e adequação semântica. No entanto, determinar se a sentença apresentada é válida ou não é uma tarefa complexa. Dentre os alunos que produziram sentenças gramaticalmente e semanticamente adequadas, houve diferenças de ordem qualitativa, como por exemplo frases mais complexas e outras mais simples. Contudo, isso não é levado em conta na grade de correção do VKS e o escore computado é o mesmo, acarretando uma atribuição injusta (BRUTON, 2009)

Além disso, em estágio inicial de aprendizagem pouco se produz na língua-alvo, logo é significativa a probabilidade de os aprendizes responderem esse item de maneira insatisfatória e até mesmo não o responderem. Essa possibilidade nos preocupou, como uma solução paliativa definimos aceitar respostas com a sequência mínima de duas palavras semanticamente e gramaticalmente relacionadas de forma correta. Por exemplo, uma resposta como yûmei na otera (templo famoso) recebeu escore cinco, porque demonstrou conhecimento gramatical e coerência semântica.

Após alguns ajustes, chegamos aos critérios de correção e ao formato adequado do VKS para a coleta de dados desta pesquisa. Embora tenha havido a necessidade de algumas adaptações, consideramos o VKS como a opção adequada porque seus objetivos como teste se ajustam às necessidades da pesquisa. Esse teste foi feito com a intenção de trilhar a aquisição de uma unidade lexical, em consonância com o nosso interesse de avaliar o ganho na aprendizagem lexical a partir de um ponto de vista qualitativo, ou seja, importa-nos em 
especial o quanto foi aprendido sobre uma mesma palavra, não apenas quantas palavras foram aprendidas. Além disso, o teste é simples, atendendo às exigências do contexto da pesquisa que exigia praticidade e economia de tempo.

\subsubsection{Os pós-testes imediato e postergado}

Após a intervenção, realizamos dois pós-testes VKS. Na aula seguinte ao término da sequência didática, aplicamos o PTI (Anexo D), para avaliar o ganho de conhecimento lexical a curto prazo. O PTP (Anexo E) foi realizado 30 dias após o primeiro teste, com o objetivo de avaliar a aprendizagem a longo prazo. Durante o intervalo entre os testes, os alunos não tiveram contato com as palavras-alvo, ao menos durante as aulas.

Em ambas as aplicações o formato dos testes se manteve igual: sem distratores e com as dez palavras-alvo apresentadas na mesma sequência. Nos momentos de aplicação, a professora-pesquisadora explicou como responder aos testes e leu as palavras com os participantes, a fim de evitar equívocos oriundos de erro de decodificação dos fonogramas do hiragana. O tempo médio gasto pelos aprendizes para responder cada teste foi 10 minutos.

\subsection{Análise dos dados}

Os dados coletados foram analisados a partir de duas perspectivas. Inicialmente, realizamos uma análise estatística. Posteriormente, realizamos uma análise das respostas escritas dos testes.

\subsubsection{Tabulação dos dados}

A tabulação dos dados ocorreu logo após a aplicação dos testes. As categorias I e II são autoavaliativas, não há demonstração de conhecimento. As categorias III, IV e V exigem a correção manual, pois o utilizador precisa julgar a adequabilidade das respostas dadas. Por razões já expostas na subseção 3.3, delimitamos critérios adicionais para a correção e atribuição de escores, sendo eles: 
1) Não penalizar erros decorrentes de falha na decodificação ou transcrição do silabário hiragana;

2) Aceitar respostas grafadas com as letras do alfabeto romano;

3) Aceitar respostas da categoria $\mathrm{V}$ com uma sequência mínima de duas palavras semântica e gramaticalmente relacionadas de forma correta.

Fizemos duas tabulações distintas dos dados. Como as categorias I e II representam o conhecimento receptivo (reconhecimento) da palavra e as categorias III, IV e V o produtivo (uso), sintetizamos as cinco categorias em apenas duas. Dessa forma, as categorias I e II (conhecimento receptivo) receberam o escore um; as categorias III, IV e V receberam o escore dois. Denominamos esses dados de escores simplificados. O objetivo era fazer uma análise inicial quanto ao reconhecimento da palavra em ambos os grupos.

A segunda tabulação realizada foi a dos escores reais.

\subsubsection{Atribuição de notas às intervenções}

A fim de verificarmos se há alguma relação entre as intervenções pedagógicas e os resultados dos testes do GE, realizamos uma análise de correlação entre essas variáveis, buscando saber se os aprendizes que tiveram melhor desempenho nas atividades também tiveram bons resultados nos testes. O objetivo disso é confirmar se a diferença entre os escores dos testes obtidos por cada grupo é decorrente das intervenções, e não de outras variáveis externas.

Para isso, atribuímos notas às atividades complementares desenvolvidas no GE para representar quantitativamente o envolvimento dos aprendizes com as intervenções pedagógicas. As atividades, os exercícios, o caderno lexical e a aula introdutória sobre chunks foram analisados e corrigidos com base em critérios pré-estabelecidos e receberam uma nota de 0 a 10, conforme exposto no quadro da página seguinte.

As "atividades" e a "aula expositiva" passaram por uma avaliação baseada no critério da participação, uma vez que o objetivo dessas intervenções era levar os alunos a discutirem em grupo ou duplas sobre a formação de chunks. Como todos os alunos atingiram a pontuação máxima nas intervenções "atividades" e aula "expositiva”, decidimos excluir essas notas da computação da média final das intervenções, visto que poderiam mascarar o real envolvimento nas atividades. O fato de o aprendiz estar presente na aula ou ter feito as atividades em grupo não significa necessariamente que estava atento e participativo. Em 
contrapartida, o "caderno lexical" e os "exercícios" eram atividades essencialmente reflexivas e foram realizadas individualmente, por isso suas notas são mais representativas do real envolvimento dos aprendizes. Dessa forma, para compor a média das notas atribuídas às intervenções, consideramos apenas as notas dos exercícios e do caderno lexical. Utilizamos esse dado final para realizar a análise de correlação entre as variáveis intervenções e desempenho demonstrado nos testes.

Tabela 5 - Critérios e escalas de pontuação para atribuição de notas às intervenções

\begin{tabular}{|c|c|c|}
\hline Tipo de intervenção & Critério de avaliação & Atribuição de notas \\
\hline \multirow{6}{*}{ Aula introdutória } & \multirow{3}{*}{$\begin{array}{l}\text { - Presença } \\
\text { *Total de aulas: } 2\end{array}$} & Ausente \\
\hline & & Participação parcial \\
\hline & & Presente \\
\hline & \multirow{3}{*}{$\begin{array}{l}\text { - Realizou todas as atividades de } \\
\text { sensibilização? } \\
\text { *Total de atividades: } 2 \\
\end{array}$} & Não \\
\hline & & Parcialmente \\
\hline & & $\mathrm{Sim}$ \\
\hline \multirow{3}{*}{ Atividades } & \multirow{3}{*}{$\begin{array}{l}\text { - Realizou todas as atividades? } \\
\text { *Total de atividades: } 3\end{array}$} & Não \\
\hline & & Parcialmente \\
\hline & & Sim \\
\hline Exercícios & $\begin{array}{l}\text { - Quantos exercícios foram } \\
\text { respondidos corretamente? }\end{array}$ & $\begin{array}{l}\text { Total de itens: } 15 \\
\text { Valor de cada item: } 0,666\end{array}$ \\
\hline Caderno lexical-L13 & $\begin{array}{l}\text { - Completou todos os itens com } \\
\text { opções válidas? }\end{array}$ & $\begin{array}{l}\text { Total de itens: } 75 \\
\text { Valor de cada item: } 0,133\end{array}$ \\
\hline Caderno lexical-L14 & $\begin{array}{l}\text { - Completou todos os itens com } \\
\text { opções válidas? }\end{array}$ & $\begin{array}{l}\text { Total de itens: } 46 \\
\text { Valor de cada item: } 0,217\end{array}$ \\
\hline
\end{tabular}

\subsubsection{Análise estatística}

De acordo com Reis (1996, p.15) "a estatística descritiva consiste na recolha, análise e interpretação de dados numéricos através da criação de instrumentos adequados: quadros, gráficos e indicadores numéricos". Já Hout (2002, p.60) conceitua a estatística descritiva como "o conjunto das técnicas e das regras que resumem a informação recolhida sobre uma amostra ou uma população, e isso sem distorção nem perda de informação".

A partir da tabulação dos escores simplificados, analisamos descritivamente os seguintes aspectos com base nos gráficos e tabelas gerados: 
- Quantidade e porcentagem de palavras reconhecidas no PTI por aluno em cada um dos grupos;

- Quantidade e porcentagem de palavras reconhecidas no PTP por aluno em cada um dos grupos;

- Diferença entre a quantidade e porcentagem de palavras reconhecidas no PTI e no PTP em cada grupo;

- Diferença entre a porcentagem de palavras reconhecidas no PTI e no PTP do GE;

- Diferença entre a porcentagem de palavras reconhecidas no PTI e PTP do GC.

A partir da tabulação dos escores reais, analisamos descritivamente os seguintes aspectos com base nos gráficos e tabelas gerados:

- Quantidade e porcentagem de cada escores obtido em cada grupo no PTI;

- Quantidade e porcentagem de cada escores obtido em cada grupo no PTP;

- Diferença entre a quantidade de cada escore do PTI e do PTP do GE e do GC;

- Diferença entre a quantidade de cada escore no PTI e no PTP do GE;

- Diferença entre a quantidade de cada escore no PTI e no PTP do GC;

- Diferença entre a porcentagem de palavras reconhecidas no PTI e PTP do GC;

- Média ponderada dos escores obtidos no PTI por cada aluno, nos GE e GC;

- Média ponderada dos escores obtidos no PTP por cada aluno, nos GE e GC;

- Diferença entre as médias dos escores obtidos em cada grupo no PTI e no PTP;

- Diferença entre as médias dos escores obtidos nos PTI e no PTP do GE;

- Diferença entre as médias dos escores obtidos nos PTI e no PTP do GC;

- Correlação entre as médias das intervenções e as médias dos escores reais obtidos no PTI do GE;

- Correlação entre as médias das intervenções e as médias dos escores reais obtidos no PTP do GE;

- Correlação entre a diferença dos escores obtidos no PTI e no PTP do GE e a média das intervenções.

\subsubsection{Os testes estatísticos}

Os testes estatísticos utilizados foram: 
- Teste de Wilcoxon Pareado, para verificar:

1) Se há diferença significativa entre o número de palavras reconhecidas no PTI e no PTP em cada sala (escores simplificados);

2) Se há diferença significativa entre as médias de escores obtidos no PTI e no PTP por cada aluno em cada sala (escores reais).

- Teste de Wilcoxon para duas amostras independentes, para verificar:

1) Se há diferença significativa entre os grupos no número de palavras reconhecidas em cada teste (escores simplificados);

2) Se há diferença significativa entre os grupos nas médias de escores obtidos em cada teste (escores reais).

- Coeficiente de correlação de Spearman, para verificar se há alguma correlação entre a variável intervenção pedagógica e desempenho nos testes no GE.

O Teste de Wilcoxon é um teste estatístico não-paramétrico, recomendado para pesquisas na área de educação, que tem como objetivo comparar o desempenho de sujeitos, individualmente ou em pares de sujeitos, para verificar se há diferenças significativas entre os seus resultados (FEIJOO, 1996, p.52).

O teste verifica a validade de uma entre duas hipóteses. A primeira, hipótese nula, estabelece que não há diferenças significativas entre os dados das amostras analisadas. A segunda, hipótese alternativa, estabelece que há diferenças significativas entre os dados das amostras analisadas (TRIOLA, 2011, p.680).

O Teste de Correlação de Sperman também é um teste não paramétrico para amostras com pares correspondentes. É usado para testar uma associação entre duas variáveis. De acordo com Feijoo (1996, p.70),

O coeficiente de correlação é um índice que expressa o grau de associação entre duas ou mais variáveis. Para se atingir este coeficiente, é preciso medir as duas variáveis. O primeiro passo é conseguir, na mesma amostra, duas medidas dos respectivos indivíduos: uma medida de $\mathrm{X}$ e outra de $\mathrm{Y}$, as quais serão emparelhadas.

As variáveis que analisaremos serão intervenção pedagógica e desempenho nos testes.

Escolhemos testes estatísticos não-paramétricos porque são indicados para amostras pequenas, sem distribuição normal ou qualquer outra particular e com variáveis ordinais ou nominais (TRIOLA, 2011, p. 663). 
Todos os testes estatísticos foram realizados com uso do programa Excel e os resultados foram revisados por um profissional da área de exatas.

\subsubsection{Análise das respostas escritas}

Durante a atribuição de escores dos testes, observamos que as respostas escritas apresentavam alguns padrões que indicavam possíveis influências da AL. Diante disso, decidimos complementar a análise estatística descritiva com uma análise das respostas escritas. O objetivo é complementar o quadro de evidências que nos norteará na elaboração das conclusões referentes ao nosso problema de pesquisa. 


\section{IV - APRESENTAÇÃO E ANÁLISE DOS RESULTADOS}

Neste capítulo, apresentamos e analisamos descritivamente os dados coletados no PTI e no PTP. Não incluímos os resultados do pré-teste, porque selecionamos como palavras-alvo apenas as que foram julgadas como completamente desconhecidas pelos aprendizes. Iniciamos com a análise estatística descritiva. Todos os testes continham dez palavras-alvo. $\mathrm{O}$ número de participantes do GE foram 12, totalizando 120 respostas em cada teste; do GC foram 11, com o total de 110 respostas por teste. Como os números de participantes e respostas não eram iguais nos dois grupos, apresentamos os dados em porcentagem, a fim de facilitar a compreensão do quanto representa cada quantidade dentro do número total de respostas de cada grupo. Posteriormente realizamos uma análise das respostas escritas dos testes à luz do arcabouço teórico deste estudo, buscando identificar evidências de um possível efeito das intervenções baseadas na AL no desempenho dos aprendizes.

\subsection{Análise estatística descritiva dos escores simplificados}

Para analisarmos os dados, tomamos como referência pesquisas que utilizaram o VKS como instrumento de coleta de dados e apresentam delineamento semelhante à nossa investigação (ZILLES, 2001; PEREIRA, 2006; BARREIROS, 2014; SAITO, 2015; OLIVEIRA; SILVA, 2016). Assim como em alguns desses estudos, decidimos analisar os escores obtidos a partir de duas tabulações diferentes: com escores simplificados (categorias I e II receberam escore 1 e categorias as III, IV e V o escore 2) e com os escores reais. Os escores simplificados informam quanto ao número e à porcentagem de palavra que passaram a ser reconhecidas pelos participantes.

Nesta subseção apresentamos e discutimos os resultados dos escores simplificados no PTI e no PTP.

\subsubsection{Pós-teste imediato}

O PTI foi realizado na aula seguinte ao término do experimento. As tabelas 6 e 7 apresentam a quantidade, a porcentagem equivalente e a média de palavras reconhecidas por aluno do GE e do GC respectivamente. 
TABELA 6 - Número e porcentagem de palavras reconhecidas no pós-teste imediato por aluno do grupo experimental

\begin{tabular}{lccc}
\hline Participante & Reconhecidas & $\begin{array}{c}\text { Não } \\
\text { Reconhecidas }\end{array}$ & $\begin{array}{c}\text { Porcentagem } \\
\text { de palavras } \\
\text { reconhecidas }\end{array}$ \\
\hline P1 & 2 & 8 & $20 \%$ \\
P2 & 4 & 6 & $40 \%$ \\
P3 & 7 & 3 & $70 \%$ \\
P4 & 9 & 1 & $90 \%$ \\
P5 & 6 & 4 & $60 \%$ \\
P6 & 5 & 5 & $50 \%$ \\
P7 & 4 & 6 & $40 \%$ \\
P8 & 8 & 2 & $80 \%$ \\
P9 & 3 & 7 & $30 \%$ \\
P10 & 2 & 8 & $20 \%$ \\
P11 & 6 & 4 & $60 \%$ \\
P12 & 4 & 6 & $40 \%$ \\
TOTAL & $60(50 \%)$ & $60(50 \%)$ & $50 \%$ \\
Média & 4,5 & 5,5 & \\
\hline
\end{tabular}

O número total de palavras reconhecidas no GE foi $60(50 \%)$ e a média de palavras reconhecidas por aluno foi de 4,5.

TABELA 7 - Número e porcentagem de palavras reconhecidas no pós-teste imediato por aluno do grupo controle

\begin{tabular}{lccc}
\hline Participante & Reconhecidas & $\begin{array}{c}\text { Não } \\
\text { econhecida; }\end{array}$ & $\begin{array}{c}\text { Porcentagem } \\
\text { de palavras } \\
\text { reconhecidas }\end{array}$ \\
\hline P1 & 0 & 10 & $0 \%$ \\
P 2 & 6 & 4 & $60 \%$ \\
P 3 & 3 & 7 & $30 \%$ \\
P 4 & 1 & 9 & $10 \%$ \\
P 5 & 0 & 10 & $0 \%$ \\
P 6 & 1 & 9 & $10 \%$ \\
P 7 & 0 & 10 & $0 \%$ \\
P 8 & 3 & 7 & $30 \%$ \\
P 9 & 0 & 10 & $0 \%$ \\
P 10 & 2 & 8 & $20 \%$ \\
P 11 & 0 & 10 & $0 \%$ \\
TOTAL & $16(15 \%)$ & $94(85 \%)$ & $15 \%$ \\
Média & $1(10 \%)$ & $9(90 \%)$ & \\
\hline
\end{tabular}


No GC, o número total de palavras reconhecidas foi $16(15 \%)$ e a média de palavras reconhecidas por aluno foi de $1(10 \%)$ e de não reconhecidas foi $9(90 \%)$. Esses resultados mostram uma diferença visível entre os grupos no número de palavras reconhecidas, conforme ilustrado no gráfico abaixo:

GRÁFICO 1 - Comparação da porcentagem de palavras reconhecidas no pós-teste imediato do grupo explícito e do grupo controle

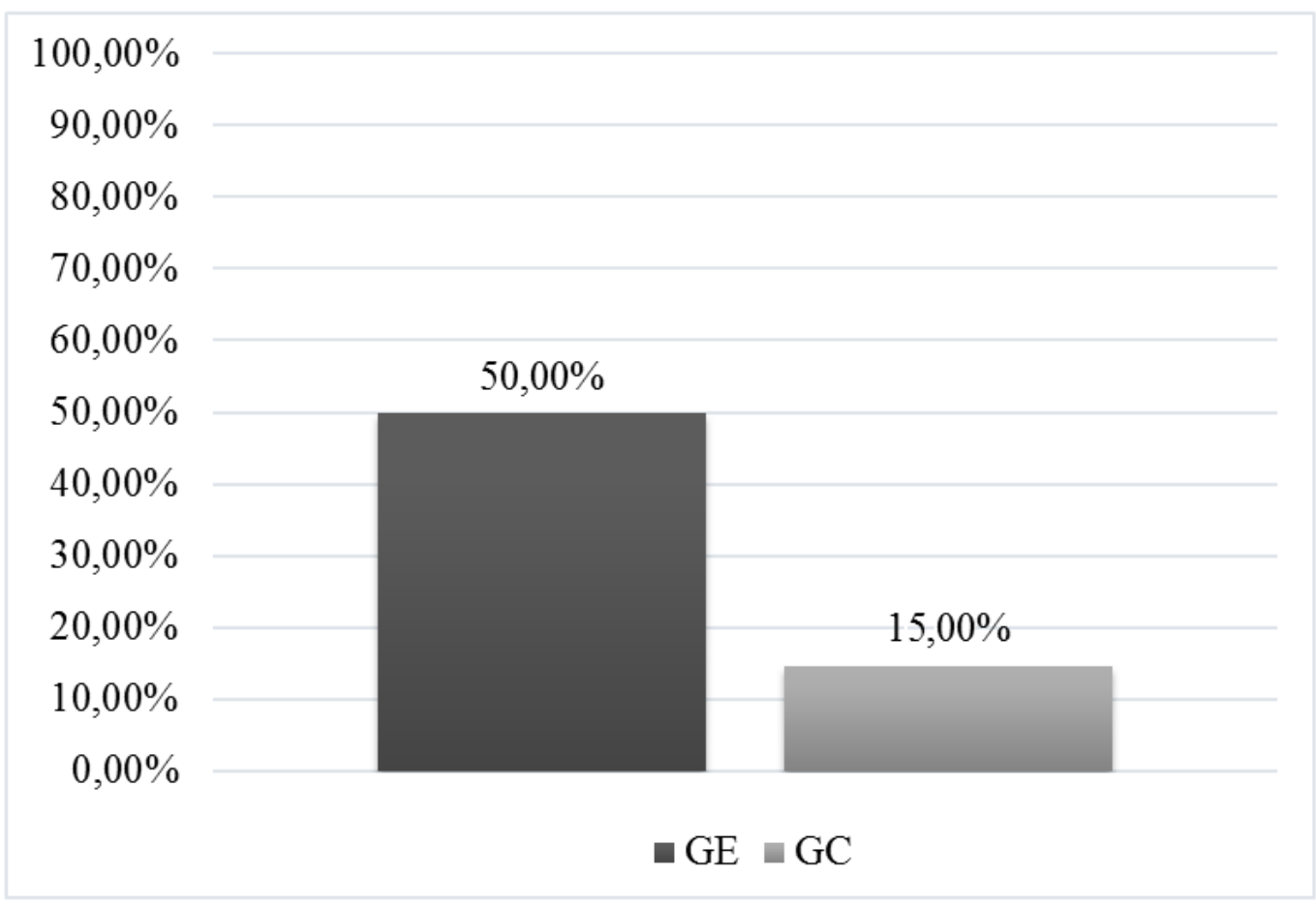

Para verificar se essa diferença é significativa, realizamos o Teste de Wilcoxon para duas amostras independentes (Anexo F). Esse procedimento foi realizado mais vezes ao longo da análise estatística dos dados desta pesquisa e em todos os casos o nível de significância foi $5 \%$. Como resultado, tivemos negada a hipótese nula, logo há diferenças, a um nível de significância de 5\%, entre a média de palavras reconhecidas em cada grupo. A partir desse resultado podemos afirmar que o GE obteve um desempenho superior ao GC no reconhecimento das palavras a curto prazo.

\subsubsection{Pós-teste postergado}

O PTP foi realizado 30 dias após o término do experimento. As tabelas 8 e 9 apresentam a quantidade, a porcentagem equivalente e a média de palavras reconhecidas por alunos do GE e do GC, respectivamente. 
TABELA 8 - Número e porcentagem de palavras reconhecidas no pós-teste postergado por aluno do grupo experimental

\begin{tabular}{lccc}
\hline Participante & Reconhecidas & $\begin{array}{c}\text { Não } \\
\text { leconhecidas }\end{array}$ & $\begin{array}{c}\text { Porcentagem } \\
\text { de palavras } \\
\text { reconhecidas }\end{array}$ \\
\hline P1 & 1 & 9 & $10 \%$ \\
P2 & 5 & 5 & $50 \%$ \\
P3 & 6 & 4 & $60 \%$ \\
P4 & 9 & 1 & $90 \%$ \\
P5 & 6 & 4 & $60 \%$ \\
P6 & 2 & 8 & $20 \%$ \\
P7 & 4 & 6 & $40 \%$ \\
P8 & 4 & 6 & $40 \%$ \\
P9 & 3 & 7 & $30 \%$ \\
P10 & 3 & 7 & $30 \%$ \\
P11 & 5 & 5 & $50 \%$ \\
P12 & 2 & 8 & $20 \%$ \\
TOTAL & $50(42 \%)$ & $70(58 \%)$ & $42 \%$ \\
Média & 4 & 6 & \\
\hline
\end{tabular}

O total de palavras reconhecidas no PTP do GE foi 50 (42\%) e a média de palavras reconhecidas por aluno foi de 4 .

TABELA 9 - Número e porcentagem de palavras reconhecidas no pós-teste postergado por aluno do grupo controle

\begin{tabular}{lccc}
\hline Participante & Reconhecidas & $\begin{array}{c}\text { Não } \\
\text { econhecida; }\end{array}$ & $\begin{array}{c}\text { Porcentagem } \\
\text { de palavras } \\
\text { reconhecidas }\end{array}$ \\
\hline P1 & 1 & 9 & $10 \%$ \\
P2 & 8 & 2 & $80 \%$ \\
P3 & 3 & 7 & $30 \%$ \\
P4 & 0 & 10 & $0 \%$ \\
P5 & 0 & 10 & $0 \%$ \\
P6 & 2 & 8 & $20 \%$ \\
P7 & 0 & 10 & $0 \%$ \\
P8 & 5 & 5 & $50 \%$ \\
P9 & 1 & 9 & $10 \%$ \\
P10 & 3 & 7 & $30 \%$ \\
P11 & 0 & 10 & $0 \%$ \\
TOTAL & $23(21 \%)$ & $87(79 \%)$ & $21 \%$ \\
Média & 1 & 9 & \\
\hline
\end{tabular}


O número total de palavras reconhecidas no GC foi $23(21 \%)$ e a média de palavras reconhecidas por aluno foi de 1.

A diferença entre os grupos no número de palavras reconhecidas se manteve no PTP, como podemos ver no gráfico a seguir:

GRÁFICO 2 - Comparação da porcentagem de palavras reconhecidas no pós-teste postergado do grupo experimental e do grupo controle

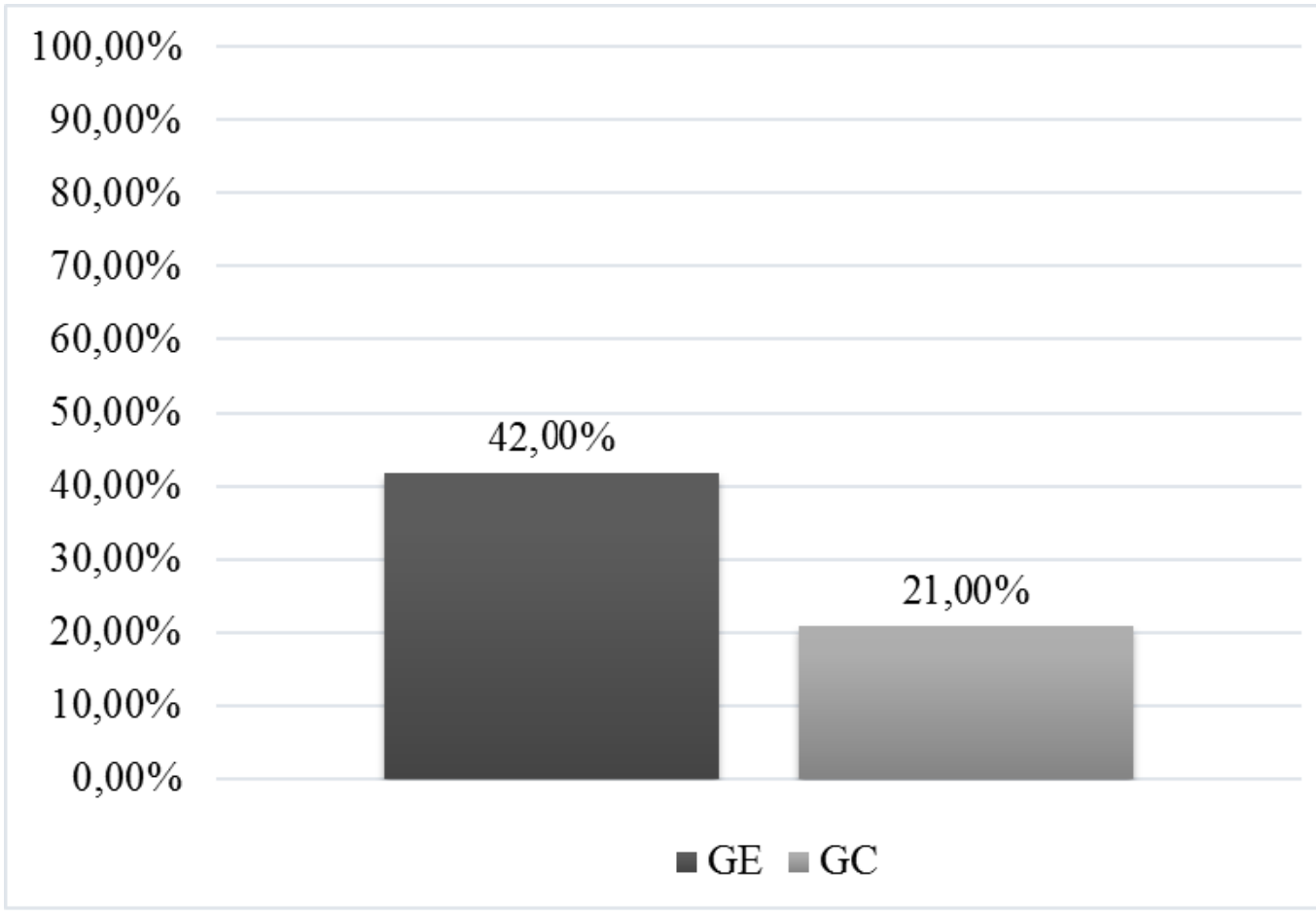

O resultado do Teste de Wilcoxon (Anexo G) nega a hipótese nula, logo também há diferenças significativas entre a porcentagem de palavras reconhecidas em cada grupo no PTP. Dessa forma, também podemos afirmar que o GE obteve um desempenho superior ao GC no reconhecimento das palavras a longo prazo.

\subsubsection{Comparação entre o pós-teste imediato e o pós-teste postergado dos grupos experimental e controle}

Com o objetivo de constatarmos se as palavras reconhecidas logo após o final do experimento (memória de curto prazo) se mantiveram na memória de longo prazo, comparamos os resultados do PTI e do PTP de cada grupo. No GE, a quantidade de palavras reconhecidas no PTI foi $60(50 \%)$ e no PTP foi 50 (42\%), conforme ilustrado no gráfico abaixo: 
GRÁFICO 3 - Comparação entre a porcentagem de palavras reconhecidas no pós-teste imediato e no pós-teste postergado do grupo experimental

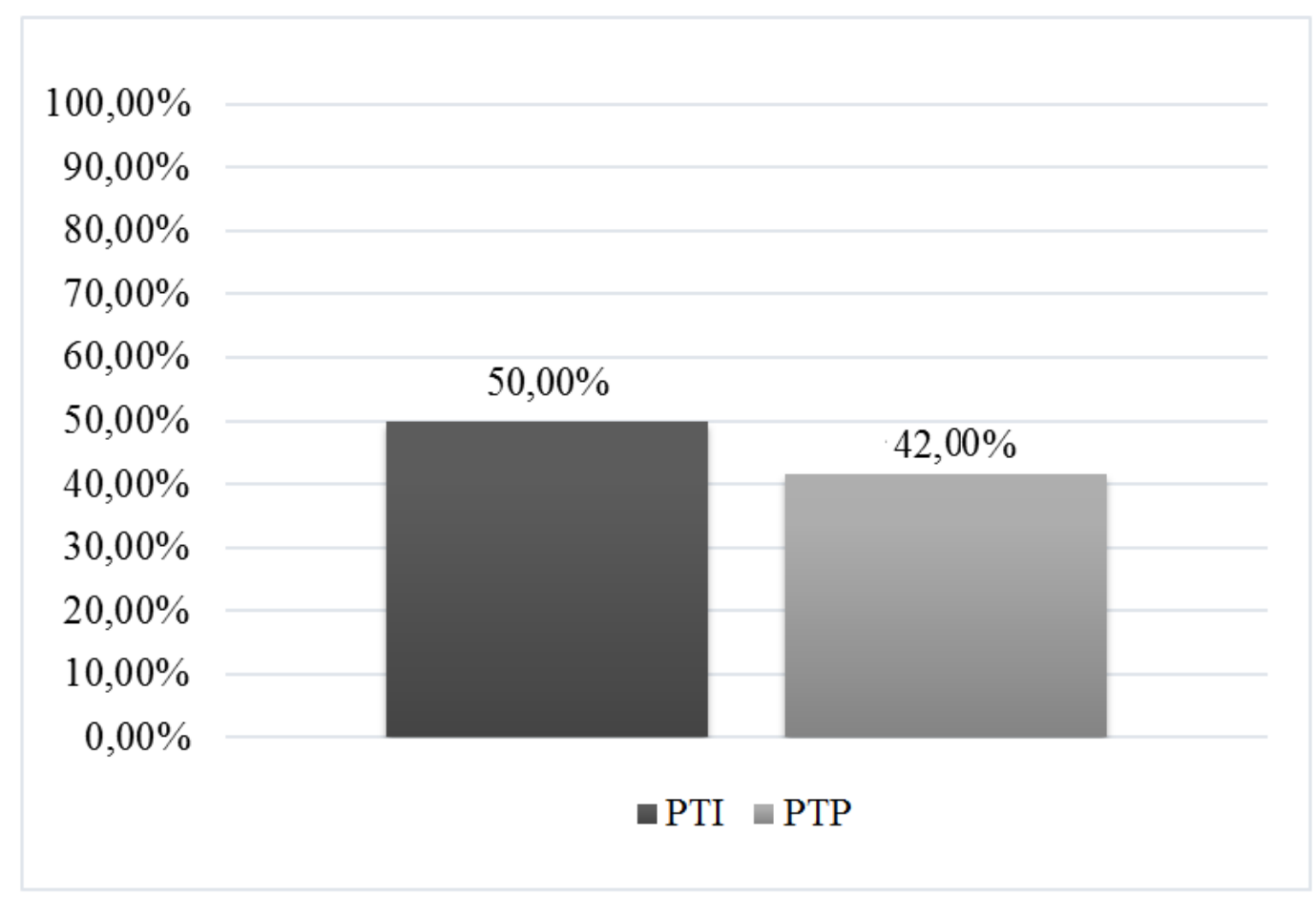

Podemos observar no gráfico que houve uma ligeira queda na quantidade de palavras reconhecidos no PTP. As palavras que sofreram baixa foram: norimasu (embarcar), duas a menos; massugu (direto, reto), duas a menos; benri (prático), uma a menos; kûkô (aeroporto), uma a menos; orimasu (desembarcar), três a menos; e yûmei (famoso), três a menos.

Para confirmarmos se essa diferença é significativa, realizamos o Teste de Wilcoxon Pareado (Anexo H), já que não se trata de uma comparação entre os grupos. O procedimento desse teste é diferente do anterior no sentido de que o requisito mínimo é que haja dados pareados referentes a uma única amostra. Nesse teste, a hipótese nula não foi rejeitada, logo não há diferenças significativas entre a porcentagem de palavras reconhecidas no PTI e no PTP do GE.

A quantidade de palavras reconhecidas no GC no PTI foi 16 (15\%) e no PTP foi 23 (21\%), como podemos ver no gráfico a seguir: 
GRÁFICO 4 - Comparação entre a porcentagem de palavras reconhecidas no pós-teste imediato e no pós-teste postergado do grupo controle

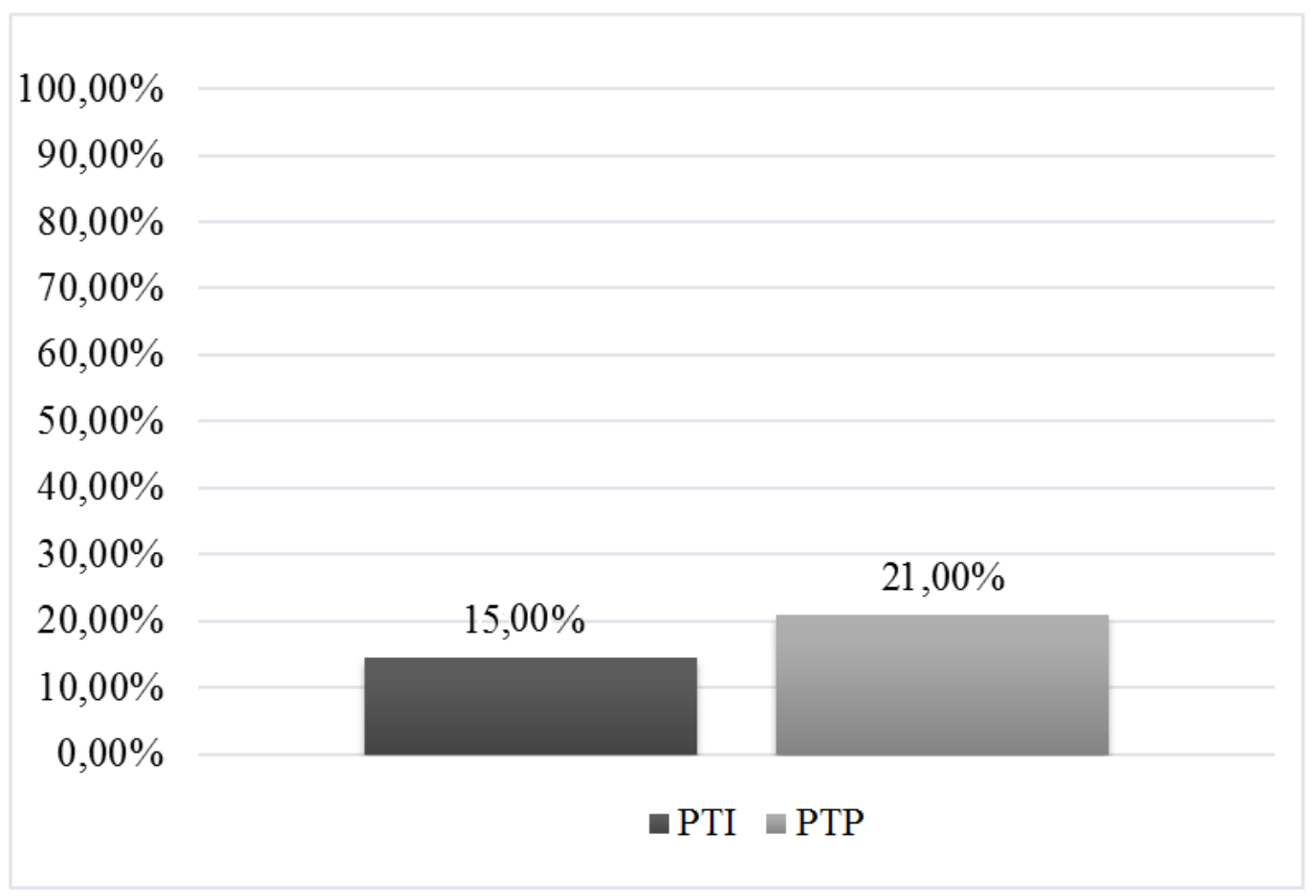

Ao contrário do que ocorreu no GE, vemos que no GC houve um pequeno aumento na quantidade de palavras reconhecidas no PTP. Novamente realizamos o Teste de Wilcoxon Pareado (Anexo I), e tivemos como resultado a hipótese nula confirmada, logo também não há diferenças significativas entre a porcentagem de palavras reconhecidas no PTI e no PTP do GC.

A quantidade de palavras reconhecidas pelo GE é estatisticamente comprovado superior ao do GC, tanto no PTI quanto no PTP. Com base nisso, temos uma evidência de que as intervenções baseadas na AL contribuíram para o ganho de conhecimento lexical sobre as palavras-alvo no nível do reconhecimento.

Com relação à análise comparativa entre os testes de cada grupo, embora tenha ocorrido uma queda no GE e um aumento no GC no número de palavras reconhecidas no PTP, em ambos os grupos, do ponto de vista estatístico essa diferença não é significativa, podendo ser atribuída ao acaso. Tendo em vista que a maioria das palavras reconhecidas no PTI também foram no PTP, ou seja, permaneceram na memória, podemos concluir que as intervenções baseadas na AL geraram efeito positivo na aprendizagem das palavras-alvo a longo prazo. 


\subsection{Análise estatística descritiva dos escores reais}

As análises estatísticas a seguir foram feitas com os escores reais dos testes. Esses possibilitaram uma análise mais detalhada da profundidade do ganho de conhecimento lexical em cada grupo.

\subsubsection{Pós-teste imediato}

As tabelas 10 e 11 mostram a quantidade de escores 1, 2, 3, 4 e 5 que cada palavra recebeu e a porcentagem equivalente no GR e no GC, respectivamente:

TABELA 10 - Quantidade e porcentagem de cada escore no pós-teste imediato do grupo experimental

\begin{tabular}{lcccccc}
\hline \multirow{2}{*}{ Palavra } & Escore & Escore & Escore & Escore & Escore & \multirow{2}{*}{ TOTAL } \\
& $\mathbf{1}$ & $\mathbf{2}$ & $\mathbf{3}$ & $\mathbf{4}$ & $\mathbf{5}$ & \\
\hline Norimasu & 0 & 2 & 0 & 4 & 6 & 12 \\
Chizu & 1 & 2 & 0 & 1 & 8 & 12 \\
Massugu & 1 & 6 & 0 & 2 & 3 & 12 \\
Benri & 0 & 8 & 0 & 1 & 3 & 12 \\
Kûkô & 0 & 1 & 1 & 5 & 5 & 12 \\
Orimasu & 0 & 4 & 1 & 5 & 2 & 12 \\
Dôyatte & 0 & 10 & 0 & 0 & 2 & 12 \\
Tôi & 2 & 10 & 0 & 0 & 0 & 12 \\
Chikai & 2 & 8 & 0 & 0 & 2 & 12 \\
Yûmei & 0 & 3 & 0 & 4 & 5 & 12 \\
TOTAL & 6 & 54 & 2 & 22 & 36 & 120 \\
Porcentagem & $\mathbf{5 , 0 0 \%}$ & $\mathbf{4 5 , 0 0 \%}$ & $\mathbf{1 , 6 7 \%}$ & $\mathbf{1 8 , 3 3 \%}$ & $\mathbf{3 0 , 0 0 \%}$ & $\mathbf{1 0 0 \%}$ \\
\hline \multicolumn{7}{r}{} \\
\hline
\end{tabular}

Conforme a tabela acima, a porcentagem de escore 1 foi $5 \%$, de 2 foi $45 \%$, de 3 foi $1,67 \%$, de 4 foi $18,33 \%$ e de 5 foi $30 \%$. Os escores mais marcados foram o 2 e o 5 .

No grupo controle, temos os seguintes resultados: 
TABELA 11 - Quantidade e porcentagem de cada escore no pós-teste imediato do grupo controle

\begin{tabular}{lcccccc}
\hline \multirow{2}{*}{ Palavra } & Escore & Escore & Escore & Escore & Escore & \multirow{2}{*}{ TOTAL } \\
\hline Norimasu & $\mathbf{1}$ & $\mathbf{2}$ & $\mathbf{3}$ & $\mathbf{4}$ & $\mathbf{5}$ & \\
Chizu & 0 & 10 & 0 & 0 & 1 & 11 \\
Massugu & 1 & 8 & 0 & 1 & 1 & 11 \\
Benri & 4 & 6 & 1 & 0 & 0 & 11 \\
Kûkô & 1 & 7 & 1 & 1 & 1 & 11 \\
Orimasu & 0 & 8 & 2 & 1 & 0 & 11 \\
Dôyatte & 1 & 9 & 0 & 0 & 1 & 11 \\
Tôi & 3 & 7 & 0 & 0 & 1 & 11 \\
Chikai & 3 & 7 & 1 & 0 & 0 & 11 \\
Yûmei & 4 & 7 & 0 & 0 & 0 & 11 \\
TOTAL & 2 & 6 & 1 & 1 & 1 & 11 \\
Porcentagem & $\mathbf{1 7 , 2 7 \%}$ & $\mathbf{6 8 , 1 8 \%}$ & $\mathbf{5 , 4 5 \%}$ & $\mathbf{3 , 6 4 \%}$ & $\mathbf{5 , 4 5 \%}$ & $\mathbf{1 0 0 \%}$ \\
\hline \multicolumn{7}{r}{} \\
\hline
\end{tabular}

No GC, 17, 27\% dos escores foram 1, 68,18\% foram 2, 5,45\% foram 3, 3,64\% foram 4 e 5,45\% foram 5 . Os escores mais marcados foram o 2 e o 1 .

O gráfico abaixo mostra a comparação da quantidade de cada escores do GE e do GC.

GRÁFICO 5 - Comparação da quantidade de cada escore do pós-teste imediato do grupo experimental e do grupo controle

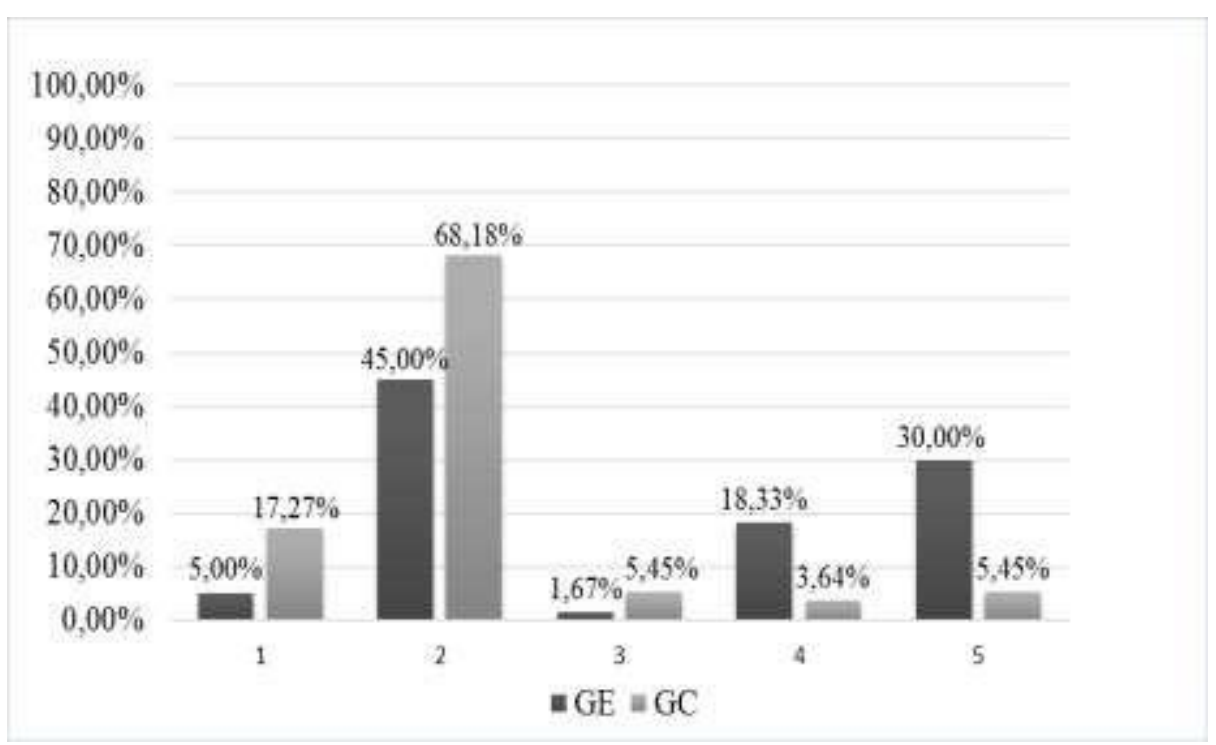

O GE teve 36 respostas com escore 5, já o GC teve apenas 6. Tendo em vista que o escore 5 representa o conhecimento produtivo da palavra-alvo e que a quantidade de escores que representam conhecimento receptivo são menores no GE do que no GC, temos evidências 
numéricas de que o GE teve ganho de conhecimento lexical profundo superior ao do GC. Com base nisso, podemos inferir que as intervenções baseadas na AL também contribuíram para a aprendizagem das palavras-alvo, a curto prazo, no que se refere à profundidade do conhecimento.

\subsubsection{Pós-teste postergado}

As tabelas 12 e 13 mostram a quantidade de escores 1,2, 3, 4 e 5 que cada palavra recebeu nos dois grupos e a porcentagem equivalente:

TABELA 12 - Quantidade e porcentagem de cada escore no pós-teste postergado do grupo experimental

\begin{tabular}{|c|c|c|c|c|c|c|}
\hline Palavra & $\begin{array}{c}\text { Escore } \\
1\end{array}$ & $\begin{array}{c}\text { Escore } \\
2\end{array}$ & $\begin{array}{c}\text { Escore } \\
\mathbf{3}\end{array}$ & $\begin{array}{c}\text { Escore } \\
4\end{array}$ & $\begin{array}{c}\text { Escore } \\
5\end{array}$ & TOTAL \\
\hline Norimasu & 0 & 4 & 2 & 1 & 5 & 12 \\
\hline Chizu & 0 & 3 & 3 & 1 & 5 & 12 \\
\hline Massugu & 4 & 5 & 1 & 0 & 2 & 12 \\
\hline Benri & 0 & 8 & 0 & 2 & 2 & 12 \\
\hline$K \hat{u} k \hat{o}$ & 0 & 1 & 4 & 3 & 4 & 12 \\
\hline Orimasu & 0 & 7 & 0 & 3 & 2 & 12 \\
\hline Dôyatte & 0 & 10 & 0 & 0 & 2 & 12 \\
\hline$T \hat{o} i$ & 2 & 10 & 0 & 0 & 0 & 12 \\
\hline Chikai & 2 & 8 & 0 & 0 & 2 & 12 \\
\hline Yûmei & 1 & 5 & 1 & 0 & 5 & 12 \\
\hline TOTAL & 9 & 61 & 11 & 10 & 29 & 120 \\
\hline Porcentagem & $7,50 \%$ & $50,83 \%$ & $9,17 \%$ & $8,33 \%$ & $24,17 \%$ & $100 \%$ \\
\hline
\end{tabular}

Com podemos ver na tabela acima, a porcentagem de escore 1 foi $7,5 \%$, de 2 foi $50,83 \%$, de 3 foi $9,17 \%$, de 4 foi $8,33 \%$ e de 5 foi $24,17 \%$. Os escores mais marcados foram o 2 e o 5 .

A seguir, os resultados do GC: 
TABELA 13 - Quantidade e porcentagem de cada escore no pós-teste postergado do grupo controle

\begin{tabular}{lllllllc}
\hline Palavra & $\begin{array}{c}\text { Escore } \\
\mathbf{1}\end{array}$ & $\begin{array}{c}\text { Escore } \\
\mathbf{2}\end{array}$ & $\begin{array}{c}\text { Escore } \\
\mathbf{3}\end{array}$ & $\begin{array}{c}\text { Escore } \\
\mathbf{4}\end{array}$ & $\begin{array}{c}\text { Escore } \\
\text { TOTAL }\end{array}$ & TOTA \\
\hline Norimasu & 0 & 8 & 1 & 1 & 1 & 11 \\
Chizu & 0 & 9 & 0 & 1 & 1 & 11 \\
Massugu & 5 & 4 & 2 & 0 & 0 & 11 \\
Benri & 2 & 7 & 1 & 0 & 1 & 11 \\
Kûkô & 2 & 3 & 4 & 1 & 1 & 11 \\
Orimasu & 1 & 8 & 0 & 1 & 1 & 11 \\
Dôyatte & 1 & 8 & 0 & 0 & 2 & 11 \\
Tôi & 3 & 7 & 1 & 0 & 0 & 11 \\
Chikai & 3 & 7 & 0 & 0 & 1 & 11 \\
Yûmei & 1 & 8 & 1 & 0 & 1 & 11 \\
TOTAL & $\mathbf{1 8}$ & $\mathbf{6 9}$ & $\mathbf{1 0}$ & $\mathbf{4}$ & $\mathbf{9}$ & 110 \\
Porcentagem & $\mathbf{1 6 , 3 6 \%}$ & $\mathbf{6 2 , 7 3 \%}$ & $\mathbf{9 , 0 9 \%}$ & $\mathbf{3 , 6 4 \%}$ & $\mathbf{8 , 1 8 \%}$ & $100 \%$ \\
\hline
\end{tabular}

A porcentagem de cada um dos escores no GC foram: $1-16,36 \% ; 2-62,73 \% ; 3-$ $9,09 \%, 4-3,64 \% ; 5-8,18 \%$. Os escores mais marcados foram o 2 e o 1 .

O gráfico a seguir mostra a comparação da quantidade de cada escore do GE e do GC.

GRÁFICO 6 - Comparação da quantidade de cada escore do pós-teste postergado do grupo experimental e do grupo controle

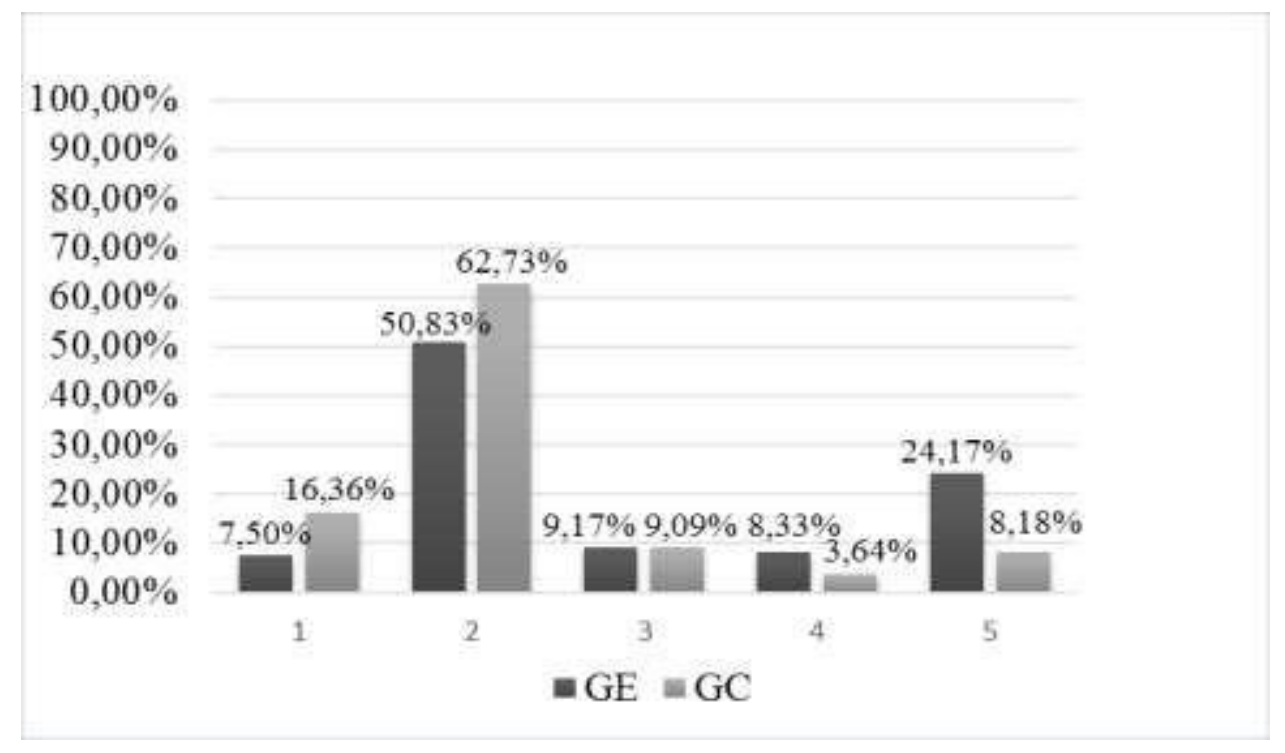

No GC houve um aumento, em relação ao PTI, na quantidade dos seguintes escores: 2 (10 a mais), 3 (4 a mais) e 5 (3 a mais). Em contrapartida, no GE houve uma queda nos seguintes escores: 4 (12 a menos) e 5 ( 7 a menos). Mesmo assim, novamente o GE teve mais 
escores que representam conhecimento produtivo do que o $\mathrm{GC}$, evidência de que as intervenções baseadas na AL contribuíram para a aprendizagem das palavras-alvo no que se refere à profundidade do conhecimento também a longo prazo, uma vez que a maioria dos escores obtidos no PTI também foram no PTP

\subsubsection{Comparação entre o pós-teste imediato e o pós-teste postergado dos grupos experimental e controle}

Assim como fizemos com os escores simplificados, também realizamos com os escores reais a comparação dos resultados obtidos no PTI e no PTP de cada grupo. O objetivo é verificar se o desempenho é igual ou superior nos dois testes, indicando a manutenção das palavras-alvo na memória de longo prazo. Interessa-nos, em especial, saber se as palavrasalvo que alcançaram escores representativos de conhecimento produtivo no PTI também alcançaram no PTP.

GRÁFICO 7 - Comparação da quantidade de cada escore do pós-teste imediato e do pós-teste postergado do grupo experimental

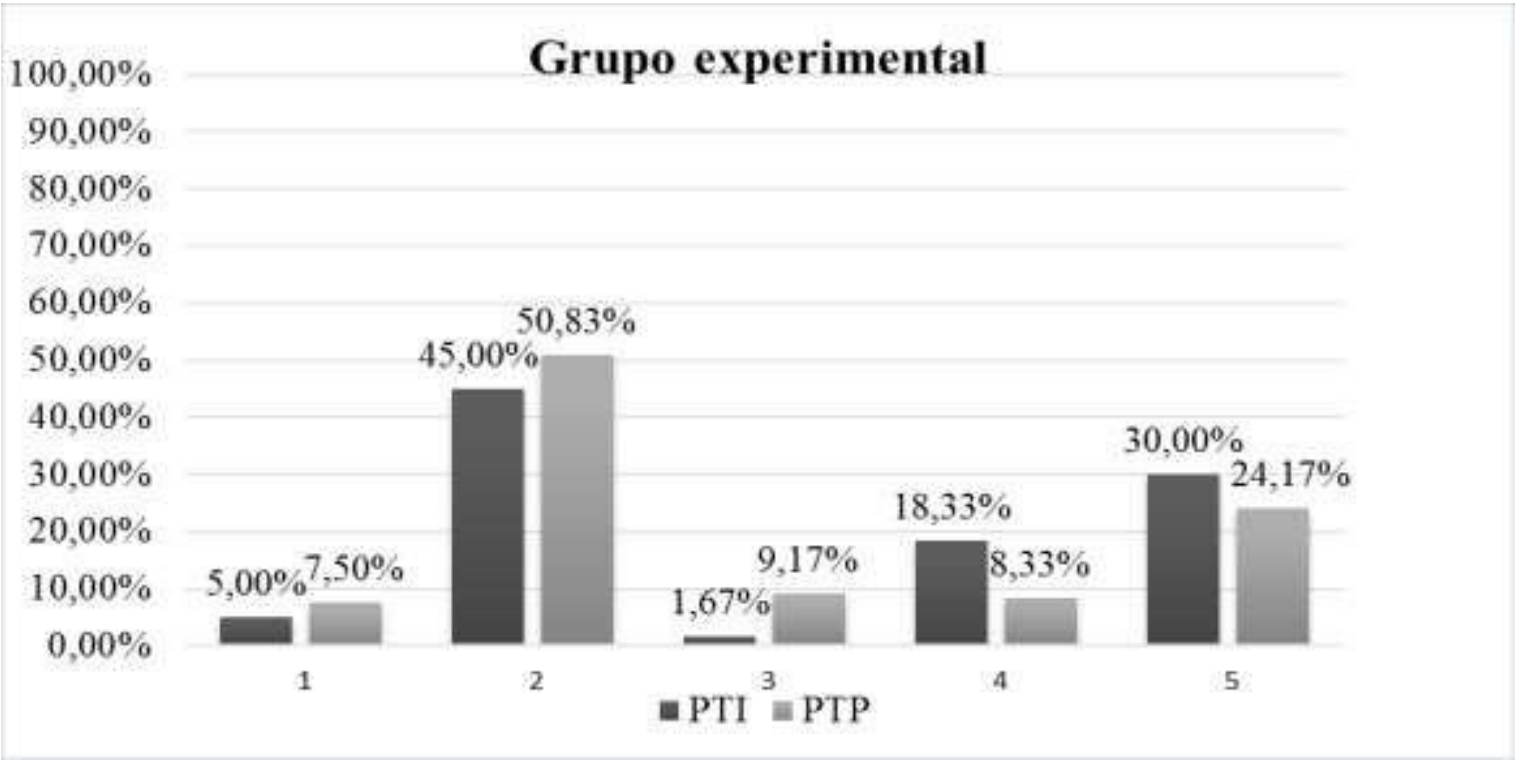

No GE, os escores 5 e 4 sofreram uma pequena queda, mas os escore 3 teve um aumento. Isso pode indicar que algumas palavras que no PTI se mostraram conhecidas ao do uso adequado, perderam força na memória do aprendiz e foram realocadas para a faixa da incerteza, pois o escore 3 se refere a categoria III - "Eu já vi essa palavra, eu acho que ela 
significa...". Como os escores 1 e 2 também tiveram aumento, essas palavras também podem ter sido parcialmente ou completamente esquecidas.

Recorremos os dados brutos para identificar onde ocorreram as alterações dos escores entre os testes do GE e as organizamos na tabela abaixo:

TABELA 14 - Alterações ocorridas entre os escores do pós-teste imediato e do pós-teste postergado do grupo experimental

\begin{tabular}{|c|c|c|c|c|c|}
\hline Palavra & Alteração & $\begin{array}{l}\text { Número de } \\
\text { ocorrências }\end{array}$ & Palavra & Alteração & $\begin{array}{l}\text { Número de } \\
\text { ocorrências }\end{array}$ \\
\hline \multirow{6}{*}{ Norimasu } & $5 \rightarrow 2$ & 2 & \multirow{4}{*}{ Orimasu } & $5 \rightarrow 2$ & 1 \\
\hline & $4 \rightarrow 2$ & 2 & & $3 \rightarrow 2$ & 1 \\
\hline & $4 \rightarrow 3$ & 1 & & $4 \rightarrow 2$ & 1 \\
\hline & $4 \rightarrow 5$ & 1 & & $4 \rightarrow 5$ & 1 \\
\hline & $2 \rightarrow 4$ & 1 & \multirow{2}{*}{$T \hat{o} i$} & $2 \rightarrow 1$ & 2 \\
\hline & $2 \rightarrow 3$ & 1 & & $1 \rightarrow 2$ & 2 \\
\hline \multirow{4}{*}{ Chizu } & $5 \rightarrow 4$ & 1 & \multirow{2}{*}{ Chikai } & $2 \rightarrow 1$ & 1 \\
\hline & $5 \rightarrow 3$ & 2 & & $1 \rightarrow 2$ & 1 \\
\hline & $4 \rightarrow 3$ & 1 & \multirow{7}{*}{ Benri } & $5 \rightarrow 2$ & 2 \\
\hline & $1 \rightarrow 2$ & 1 & & $4 \rightarrow 3$ & 1 \\
\hline \multirow{4}{*}{ Massugu } & $2 \rightarrow 1$ & 1 & & $4 \rightarrow 2$ & 1 \\
\hline & $4 \rightarrow 2$ & 1 & & $2 \rightarrow 1$ & 1 \\
\hline & $4 \rightarrow 1$ & 1 & & $4 \rightarrow 5$ & 2 \\
\hline & $5 \rightarrow 3$ & 1 & & $5 \rightarrow 2$ & 1 \\
\hline \multirow{7}{*}{$K \hat{u} k \hat{o}$} & $5 \rightarrow 4$ & 2 & & $2 \rightarrow 4$ & 1 \\
\hline & $5 \rightarrow 2$ & 1 & & & \\
\hline & $5 \rightarrow 3$ & 1 & & & \\
\hline & $4 \rightarrow 3$ & 2 & & & \\
\hline & $4 \rightarrow 5$ & 3 & & & \\
\hline & $2 \rightarrow 3$ & 1 & & & \\
\hline & $\underline{3} \rightarrow \underline{4}$ & 1 & & & \\
\hline
\end{tabular}

As alterações de escore 5 para escore 4 não significam esquecimento, já que essa pontuação é atribuída às palavras que foram usadas de forma gramaticalmente incorreta, mas com adequação semântica. Já as que mudaram para o escore 3 são mais preocupantes, pela razão já mencionada acima. Contudo, de acordo com o VKS, a palavra ainda se encontra na zona do conhecimento produtivo. Metade das alterações se deram do escore 5 para o escore 2, o qual representa outro nível de conhecimento, o receptivo. Nesses casos, houve esquecimento parcial das palavras-alvo.

Com relação à comparação dos testes do GC temos o seguinte gráfico: 
GRÁFICO 8 - Comparação da quantidade de cada escore do pós-teste imediato e do pós-teste postergado do grupo controle

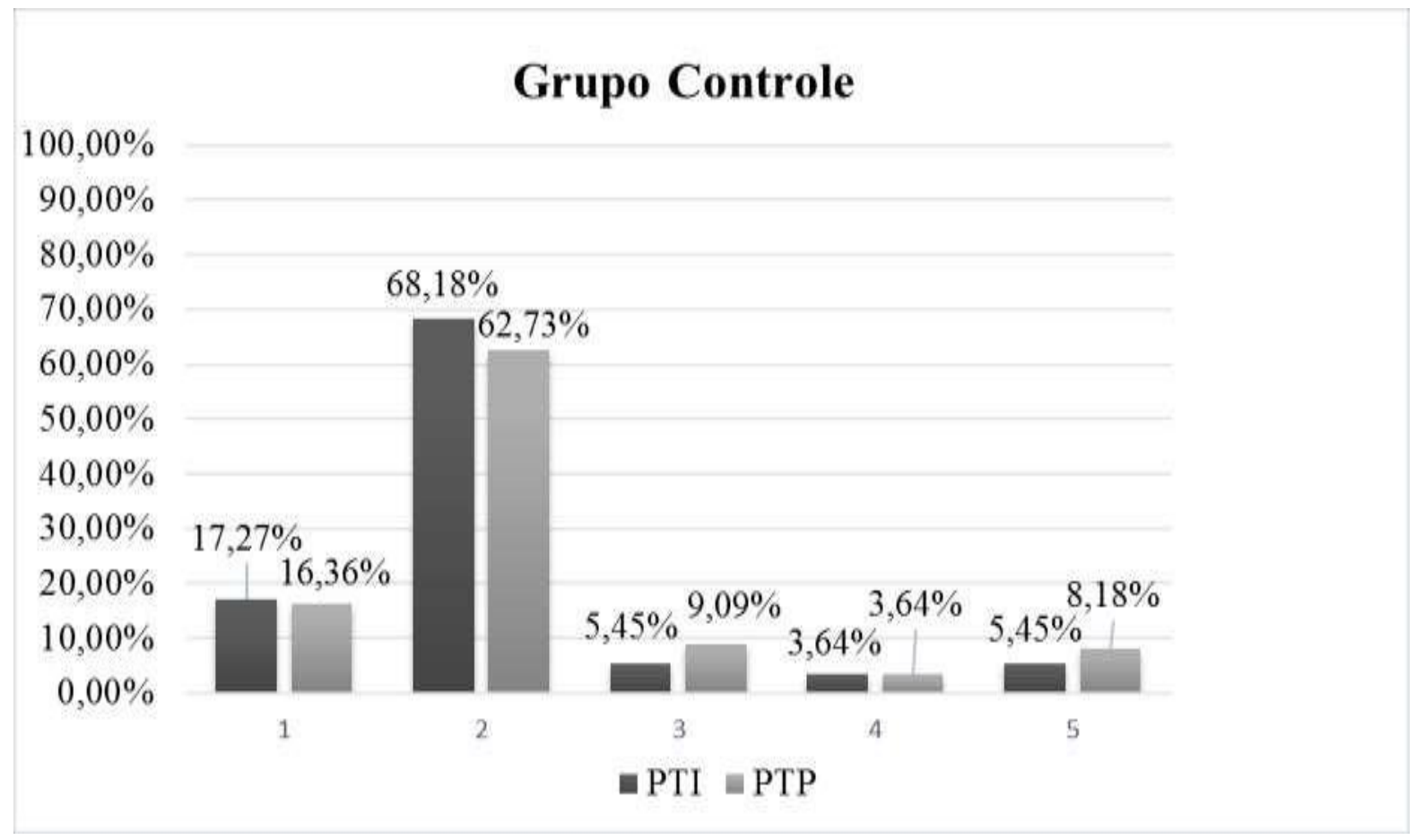

No GC ocorreu um aumento na porcentagem dos escores 3, 4 e 5 (conhecimento produtivo) e uma baixa nos escores 1 e 2 (conhecimento receptivo). As razões pelas quais houve um ganho de conhecimento lexical não é passível de análise, visto que não temos como saber o que levou a isso. Ademais, como o objetivo dessa comparação é verificar a aprendizagem a longo prazo, não é relevante nesta pesquisa as palavras que foram melhor pontuadas no PTP. Ao consultarmos os dados brutos, observamos que apenas duas palavras sofreram alterações negativa. A palavra benri (prático) foi uma vez do escore 4 para o 3 e outra do escore 3 para 2. A palavra yûmei (famoso) foi do escore 4 para 2 uma vez.

\subsubsection{Análise estatística descritiva das médias dos escores do pós-teste imediato do grupo experimental e do grupo controle}

As tabelas 15 e 16 mostram a média dos escores de cada participante do grupo experimental e controle, nessa ordem, bem como a média de cada grupo no PTI. 
TABELA 15 - Médias dos escores do pós-teste imediato do grupo experimental

\begin{tabular}{lcccccc}
\hline Participante & $\begin{array}{c}\text { Escore } \\
\mathbf{1}\end{array}$ & $\begin{array}{c}\text { Escore } \\
\mathbf{2}\end{array}$ & $\begin{array}{c}\text { Escore } \\
\mathbf{3}\end{array}$ & $\begin{array}{c}\text { Escore } \\
\mathbf{4}\end{array}$ & $\begin{array}{c}\text { Escore } \\
\mathbf{5}\end{array}$ & $\begin{array}{c}\text { Média dos } \\
\text { escores }\end{array}$ \\
\hline P1 & 2 & 6 & 0 & 1 & 1 & 2,3 \\
P2 & 0 & 6 & 0 & 1 & 3 & 3,1 \\
P3 & 0 & 3 & 0 & 0 & 7 & 4,1 \\
P4 & 0 & 1 & 0 & 3 & 6 & 4,4 \\
P5 & 0 & 4 & 0 & 3 & 3 & 3,5 \\
P6 & 0 & 5 & 1 & 1 & 3 & 3,2 \\
P7 & 1 & 5 & 1 & 3 & 0 & 2,6 \\
P8 & 0 & 2 & 0 & 2 & 6 & 4,2 \\
P9 & 0 & 7 & 0 & 1 & 2 & 2,8 \\
P10 & 1 & 7 & 0 & 2 & 0 & 2,3 \\
P11 & 2 & 2 & 0 & 2 & 4 & 3,4 \\
P12 & 0 & 6 & 0 & 3 & 1 & 2,9 \\
& & & \multicolumn{5}{c}{ Média do grupo } & $\mathbf{3 , 2 3}$ \\
\hline
\end{tabular}

TABELA 16 - Médias dos escores do pós-teste imediato do grupo controle

\begin{tabular}{lcccccc}
\hline Participante & $\begin{array}{c}\text { Escore } \\
\mathbf{1}\end{array}$ & $\begin{array}{c}\text { Escore } \\
\mathbf{2}\end{array}$ & $\begin{array}{c}\text { Escore } \\
\mathbf{3}\end{array}$ & $\begin{array}{c}\text { Escore } \\
\mathbf{4}\end{array}$ & $\begin{array}{c}\text { Escore } \\
\mathbf{5}\end{array}$ & $\begin{array}{c}\text { Média dos } \\
\text { escores }\end{array}$ \\
\hline P1 & 2 & 8 & 0 & 0 & 0 & 1,8 \\
P2 & 1 & 3 & 0 & 1 & 5 & 3,6 \\
P3 & 2 & 5 & 2 & 0 & 1 & 2,3 \\
P4 & 2 & 7 & 0 & 1 & 0 & 2 \\
P5 & 3 & 7 & 0 & 0 & 0 & 1,7 \\
P6 & 2 & 7 & 1 & 0 & 0 & 1,9 \\
P7 & 2 & 8 & 0 & 0 & 0 & 1,8 \\
P8 & 0 & 7 & 2 & 1 & 0 & 2,4 \\
P9 & 2 & 8 & 0 & 0 & 0 & 1,8 \\
P10 & 0 & 8 & 1 & 1 & 0 & 2,3 \\
P11 & 3 & 7 & 0 & 0 & 0 & 1,7 \\
& & & \multicolumn{5}{c}{ Média do grupo } & $\mathbf{2 , 1 2}$ \\
\hline
\end{tabular}

Diante de todos os resultados das análises realizadas até o momento, como já era de se esperar, o GE obteve uma média de escores superior ao GC. Realizamos o Teste de Wilcoxon (Anexo $\mathrm{J}$ ) para verificar se essa diferença é significativa e tivemos negada a hipótese nula, o que nos permite afirmar que há diferença significativa entre a média dos escores do PTI do GE e do GC. 
4.2.5 Análise estatística descritiva das médias dos escores do pós-teste postergado do grupo experimental e do grupo de controle

As tabelas 17 e 18 mostram a média dos escores de cada participante do grupo experimental e controle, respectivamente, e a média de cada grupo no PTP.

TABELA 17 - Médias dos escores do pós-teste postergado do grupo experimental

\begin{tabular}{llllllc}
\hline Participante & $\begin{array}{c}\text { Escore } \\
\mathbf{1}\end{array}$ & $\begin{array}{c}\text { Escore } \\
\mathbf{2}\end{array}$ & $\begin{array}{c}\text { Escore } \\
\mathbf{3}\end{array}$ & $\begin{array}{c}\text { Escore } \\
\mathbf{4}\end{array}$ & $\begin{array}{c}\text { Escore } \\
\mathbf{5}\end{array}$ & $\begin{array}{c}\text { Média dos } \\
\text { escores }\end{array}$ \\
\hline P1 & 3 & 6 & 0 & 0 & 1 & 2 \\
P2 & 0 & 5 & 1 & 2 & 2 & 3,1 \\
P3 & 1 & 3 & 0 & 2 & 4 & 3,5 \\
P4 & 0 & 1 & 0 & 0 & 9 & 4,7 \\
P5 & 0 & 4 & 0 & 1 & 5 & 3,7 \\
P6 & 0 & 8 & 0 & 1 & 1 & 2,5 \\
P7 & 0 & 6 & 2 & 2 & 0 & 2,6 \\
P8 & 0 & 6 & 0 & 1 & 3 & 3,1 \\
P9 & 1 & 6 & 0 & 1 & 2 & 2,7 \\
P10 & 2 & 5 & 3 & 0 & 0 & 2,1 \\
P11 & 0 & 5 & 3 & 0 & 2 & 2,9 \\
P12 & 2 & 6 & 2 & 0 & 0 & 2 \\
& & & \multicolumn{5}{c}{ Média do grupo } & $\mathbf{2 , 9 1}$ \\
\hline
\end{tabular}

TABELA 18 - Médias dos escores do pós-teste postergado do grupo controle

\begin{tabular}{llllllcc}
\hline Participante & $\begin{array}{c}\text { Escore } \\
\mathbf{1}\end{array}$ & $\begin{array}{c}\text { Escore } \\
\mathbf{2}\end{array}$ & $\begin{array}{c}\text { Escore } \\
\mathbf{3}\end{array}$ & $\begin{array}{c}\text { Escore } \\
\mathbf{4}\end{array}$ & $\begin{array}{c}\text { Escore } \\
\mathbf{5}\end{array}$ & $\begin{array}{c}\text { Média dos } \\
\text { escores }\end{array}$ \\
\hline P1 & 1 & 8 & 0 & 1 & 0 & 2,1 \\
P2 & 1 & 1 & 0 & 0 & 8 & 4,3 \\
P3 & 0 & 7 & 2 & 0 & 1 & 2,5 \\
P4 & 1 & 9 & 0 & 0 & 0 & 1,9 \\
P5 & 3 & 7 & 0 & 0 & 0 & 1,7 \\
P6 & 0 & 8 & 2 & 0 & 0 & 2,2 \\
P7 & 5 & 5 & 0 & 0 & 0 & 1,5 \\
P8 & 0 & 5 & 2 & 3 & 0 & 2,8 \\
P9 & 1 & 8 & 1 & 0 & 0 & 2 \\
P10 & 2 & 5 & 3 & 0 & 0 & 2,1 \\
P11 & 4 & 6 & 0 & 0 & 0 & 1,6 \\
& & & \multicolumn{6}{c}{ Média do grupo } & $\mathbf{2 , 2 5}$ \\
\hline
\end{tabular}


Mais uma vez realizamos o Teste de Wilcoxon (Anexo K) para verificar se houve diferença significativa na média dos escores do PTP entre o GE e o GC. Tivemos negada a hipótese nula, o que nos permite afirmar que há diferença significativa.

\subsubsection{Análise estatística descritiva entre as médias do pós-teste imediato e do pós-teste postergado dos grupos experimental e controle}

A média dos escores do PTI do GE foi 3,23 e do PTP foi 2,91. Seguindo a tendência, houve uma queda e de acordo com o Teste de Wilcoxon (Anexo L) essa diferença é significativa.

Já no GC, a média dos escores do PTI foi 2,12 e do PTP foi 2,25. O resultado do Teste do Wilcoxon (Anexo M) aponta que essa diferença não é significativa.

\subsubsection{Análise do Coeficiente de Correlação de Spearman}

Todas as análises estatísticas realizadas acima apontam que há diferenças significativas entre o GE e o GC quanto ao desempenho nos testes, indicando superioridade do GE.

Diante disso, buscamos verificar se essa superioridade numérica se deu, de fato, em função das intervenções pedagógicas baseadas na AL, visando descartar a possibilidade de ser fruto do acaso ou de ser influência de outras variáveis não controláveis (motivação, interesse, comprometimento, atenção, entre outras). Para tal, realizamos três análises do Coeficiente de Correlação de Spearman. Em todas as análises, os valores críticos do intervalo onde há a aceitação da hipótese nula é -0,587 e 0,587.

A primeira (Anexo N) foi realizada com as variáveis média das intervenções pedagógicas e média dos escores do PTI. O resultado do coeficiente obtido foi 0,3846, portanto está dentro do intervalo que não descarta a hipótese nula. Dessa forma, não há correlação entre esses dados.

A segunda (Anexo O) procedeu com as variáveis média das intervenções pedagógicas e média dos escores do PTP. O coeficiente obtido foi - $-0,1678$, logo também está dentro do intervalo que não descarta a hipótese nula. Consequentemente, também não há correlação entre esses dados. 
A terceira (Anexo P) foi realizada com as variáveis média das intervenções pedagógicas e diferença entre as médias dos escores do PTI e PTP. O coeficiente obtido foi 0,2098, valor que também se encontra dentro do intervalo que não descarta a hipótese nula. Por conseguinte, também não há correlação entre esses dados.

As três análises de correlação indicam que a variável média das intervenções pedagógicas não influencia na variável desempenho nos testes, indicando que a diferença entre os grupos se deve a outros fatores. Como os dados da amostra é reduzida, decidimos observar diretamente os dados brutos.

TABELA 19 - Médias dos escores do pós-teste imediato, do pós-teste postergado e média das intervenções pedagógicas por aluno

\begin{tabular}{lccc}
\hline Participante & $\begin{array}{c}\text { Média escores } \\
\text { PTI }\end{array}$ & $\begin{array}{c}\text { Média escores } \\
\text { PTP }\end{array}$ & $\begin{array}{c}\text { Média } \\
\text { ntervenções }\end{array}$ \\
\hline P1 & 2,3 & 2 & $\mathbf{8 , 2 7}$ \\
P2 & 3,1 & 3,1 & $\mathbf{8 , 2 4}$ \\
P3 & 4,1 & 3,5 & $\mathbf{8 , 2 7}$ \\
P4 & 4,4 & 4,7 & $\mathbf{8 , 4 9}$ \\
P5 & 3,5 & 3,7 & $\mathbf{9 , 0 0}$ \\
P6 & 3,2 & 2,5 & $\mathbf{7 , 5 1}$ \\
P7 & 2,6 & 2,6 & $\mathbf{9 , 0 2}$ \\
P8 & 4,2 & 3,1 & $\mathbf{8 , 5 9}$ \\
P9 & 2,8 & 2,7 & $\mathbf{7 , 4 7}$ \\
P10 & 2,3 & 2,1 & $\mathbf{5 , 7 0}$ \\
P11 & 3,4 & 2,9 & $\mathbf{4 , 0 5}$ \\
P12 & 2,9 & 2 & $\mathbf{7 , 1 6}$ \\
\hline
\end{tabular}

Consideramos as possíveis explicações para esse resultado, que aponta não haver correlação entre as intervenções e o desempenho dos aprendizes:

1) Os aprendizes que alcançaram médias de escores dentro da zona do conhecimento reprodutivo (3, 4 e 5), em sua maioria, obtiveram uma pontuação média nas intervenções superior à 8. Os casos que fogem à regra, P6 e P11, podem ser explicados pelo fato de que corrigimos e atribuímos uma pontuação aos exercícios e aos cadernos lexicais dos aprendizes que não tinham sido corrigidos por eles mesmos. Isto é, não traziam respostas produzidas após um processo de correção. Diferentemente dos testes, já que após recebermos os exercícios e os cadernos lexicais, fazíamos uma correção em pares e depois com todos do grupo. Como os testes foram realizados após essas correções, os aprendizes podem ter aprendido 
mais e por isso tiveram bom desempenho, a despeito de sua pontuação média nas intervenções.

2) Houve casos em que o aprendiz alcançou média superior a 8 nas intervenções, mas a média dos escores ficou dentro da zona do conhecimento receptivo (1 e 2), como podemos ver em P1 e P7. Essas ocorrências podem ser explicadas pelo fato de que foi permitido consultar os materiais para responder os exercícios e os cadernos lexicais. Além disso, embora tenham sido orientados a realizar essas tarefas individualmente, há a possibilidade de terem consultado outro aprendiz.

Não há comprovação estatística de que há uma correlação entre as intervenções e o desempenho nos testes. No entanto, consideramos essa conclusão questionável. As explicações acima e a leitura dos dados brutos, que revelam uma concentração de aprendizes que alcançaram médias de escores dentro da zona do conhecimento produtivo (3, 4 e 5) com pontuação média nas intervenções superior a 8, leva-nos a ponderar sobre a validade desse resultado na prática. De acordo com Marques (1999, p.7) um resultado estatístico não está imune de contestação, pois:

\begin{abstract}
O grande problema encontrado pela aplicação da análise estatística é que embora ela possa ser utilizada na produção de conhecimento nos mais variados ramos da ciência, seu grau de previsão varia na mesma medida em que se deixam de lado variáveis (consideradas desprezíveis ou insignificantes) e que no conjunto acabam por afetar a veracidade dos dados e das inferências obtidas. Hoje, mais do que nunca, devido ao uso generalizado das estatísticas pela economia e pelo conjunto das ciências sociais, uma desconfiança surge: qual a certeza de que as estatísticas sejam capazes de apreender e interpretar corretamente a realidade?
\end{abstract}

Tendo em vista que a análise estatística pode não ter captado nuances e manifestações que podem influenciar nas conclusões desta pesquisa, decidimos realizar uma análise das respostas escritas dos testes.

\title{
4.3 Análise das respostas escritas dos testes
}

O procedimento para a análise teve início com a separação e organização das respostas escritas dos testes (categoria V) de ambos os grupos. Esse passo deu origem aos quadros disponíveis nos Apêndices $\mathrm{P}, \mathrm{Q}, \mathrm{R}$ e S, nos quais vemos a palavra-alvo, a produção realizada 
correspondente à palavra alvo e o escore que foi atribuído. Transcrevemos as respostas exatamente como foram escritas, mas colocamos a transliteração.

Em seguida, buscamos evidências de uma possível influência das intervenções baseadas na AL nas produções dos participantes do GE. Tomamos como norte os princípios da AL e o modelo de conhecimento lexical de Nation (2013), discutidos na subseção 2.1.4.

Posteriormente, comparamos as produções dos dois grupos, com o objetivo de identificar se as repostas do GE se diferiam das respostas do GC. Caso as evidências de influência das intervenções também fossem encontradas nas produções do GC, poderíamos concluir que essas não causaram nenhum efeito. No contrário, teríamos mais um indício de que as intervenções baseadas na AL contribuíram para a aprendizagem das palavras-alvo.

A primeira observação que podemos fazer é com relação à quantidade de respostas escritas. A soma das produções do PTI e do PTP do GE totalizam 121 produções, das quais $66(54,5 \%)$ receberam escore 5, ou seja, estavam gramaticalmente e semanticamente adequadas; no GC foram contabilizadas 38 produções, dentre as quais 15 (39\%) receberam o escore 5. A razão dessa substancial diferença pode ser atribuída ao fato de que no GE os alunos aprenderam as palavras-alvo em chunks. De acordo com a AL, aprender as palavras em blocos estimula a organização do léxico mental em chunks, processo que facilita a posterior recuperação e evita combinações não usuais.

Também notamos que nas respostas do GE foram escritas frases com as palavras-alvo inseridas em expressões fixas, como "Massugu itte kudasai" (siga reto, por favor) e "Dôyatte ikimasuka" (Como vai?); também em expressões semifixas, como “...desu kara” (porque é...). A expressão fixa "Dôyatte ikimasuka" também figurou em algumas respostas do GC, mas as demais só foram encontradas em respostas do GE. Além disso, as polipalavras basu noriba (ponto de ônibus) e takushî noriba (ponto de táxi), embora tenham sido apresentadas aos dois grupos, só foram usadas nas produções do GE. O motivo disso pode ser o fato de que no GE a atenção dos aprendizes foi direcionada para a presença de itens lexicais no vocabulário novo das lições que estavam estudando, ação não realizada no GC.

Vale ressaltar também que das 38 produções do GC, 26 são referentes às respostas de apenas dois participantes, o que nos leva a pensar que sejam aprendizes que se sobressaem e não representam o desempenho médio do grupo. Já no GE não houve essa concentração, todos os participantes produziram respostas escritas, de duas a dez cada um. Logo, o desempenho no GE foi mais homogêneo, o que nos permite inferir que o desempenho desse grupo pode estar relacionado com as intervenções baseadas na AL e não com a presença de um ou outro aprendiz brilhante que elevou a média do grupo. 
Por fim, diante do exposto acima, concluímos que temos fortes evidências de que as produções do GE são quantitativamente e qualitativamente superiores às do GC, em função das intervenções baseadas na AL. 


\section{V - CONSIDERAÇÕES FINAIS E CONCLUSÃO}

Nosso problema de pesquisa era buscar uma alternativa didático-metodológica para o ensino do léxico da LJ. Após pesquisa bibliográfica preliminar, determinamos como objetivo averiguar as contribuições do ensino sistematizado e explícito de vocabulário norteado pelos princípios da AL para a aprendizagem do léxico em LJ, a curto e longo prazo, tanto quantitativamente quanto qualitativamente

Optamos por um estudo com delineamento quase-experimental e levantamos a hipótese de que complementar a aquisição incidental com ensino sistematizado do léxico via instrução direta contribui para o desenvolvimento de uma competência lexical sólida composta por um conhecimento rico de vocabulário. A partir disso, definimos as seguintes perguntas a serem respondidas para verificarmos essa hipótese:

1) O ensino sistematizado e explícito de vocabulário norteado pelos princípios da $\mathrm{AL}$ contribui para a aprendizagem do vocabulário da $\mathrm{LJ}$ do ponto de vista quantitativo?

2) O ensino sistematizado e explícito de vocabulário norteado pelos princípios da $\mathrm{AL}$ contribui para a aprendizagem de vocabulário da LJ do ponto de vista qualitativo?

3) O ensino sistematizado e explícito de vocabulário norteado pelos princípios da $\mathrm{AL}$ contribui para a aprendizagem de vocabulário da LJ a curto e longo prazo?

Para responder essas perguntas, fizemos uma análise estatística descritiva dos escores dos testes de ambos os grupos. Posteriormente, aplicamos testes estatísticos para confirmar se as diferenças nos escores foram significativas ou não, bem como o Teste de Correlação de Sperman para verificar se houve alguma relação entre as intervenções e os resultados dos testes do GE. Também analisamos as respostas escritas (categoria v) dos testes em busca de evidências do efeito das intervenções na produção dos participantes do GE.

A análise descritiva dos escores simplificados revelou que no PTI o GC reconheceu $15 \%$ das palavras e o GE reconheceu 50\%. Já no PTP, o GC reconheceu $23 \%$ e o GE $42 \%$.

Esses resultados mostram uma diferença aparente entre os grupos no número de palavras reconhecidas, tanto no PTI quanto no PTP. De acordo com os resultados dos Testes de Wilcoxon realizados, essas diferenças são significativas. Sendo assim, podemos afirmar 
que o GE obteve um desempenho superior ao GC no reconhecimento das palavras a curto e longo prazo. Com isso, temos a primeira evidência que confirma nossa hipótese.

A análise descritiva dos escores reais revelou a profundidade do ganho de conhecimento lexical em cada grupo. O escore 5 representa o conhecimento produtivo da palavra-alvo e a quantidade total recebida em ambos os testes pelo GE e o GC é, respectivamente, 66 e 38. A quantidade foi bem inferior no GC. Somado a isso, temos o fato de que a quantidade de escores que representam conhecimento receptivo são menores no GE. Essas são evidências numéricas de que o GE teve ganho de conhecimento lexical profundo superior ao do GC. Pautados nisso, podemos inferir que as intervenções baseadas na AL também contribuíram para a aprendizagem das palavras-alvo, a curto e longo prazo, no que se refere à profundidade do conhecimento.

Também aplicamos o Teste de Wilcoxon para verificar se foram significativas as diferenças entre as médias dos escores dos grupos de ambos os testes. O resultado corrobora todas as análises anteriores ao confirmar que há diferenças significativas.

O Teste de Wilcoxon também foi aplicado para verificar se houve diferença significativa entre os resultados do PTI e do PTP do GE. Em todos os casos, a hipótese nula não foi rejeitada, logo não há diferenças significativas. Isso significa que a maioria das palavras reconhecidas no PTI também foram no PTP, ou seja, permaneceram na memória, o que nos permite concluir que as intervenções baseadas na AL geraram efeito positivo na aprendizagem das palavras-alvo a curto e longo prazo. O mesmo procedimento foi realizado com o GC e o resultado foi o igual, indicando que as palavras reconhecidas no PTI também foram no PTP.

A partir dessas análises, podemos responder afirmativamente as três perguntas que nortearam os procedimentos para a verificação da hipótese de nossa pesquisa. Contudo, para podermos afirmar se essa é válida ou não julgamos necessária a realização de um último teste estatístico, o Coeficiente de Correlação de Spearman. O objetivo era verificar se de fato há relação entre o desempenho dos participantes nos testes e as intervenções pedagógicas baseadas na AL.

As três análises realizadas indicaram não haver correlação entre as variáveis média das intervenções pedagógicas e desempenho nos testes, indicando que a diferença entre os grupos se deve a outros fatores. Isto é, não há comprovação estatística de que há uma correlação entre essas variáveis. Contudo, a leitura dos dados brutos mostra uma concentração de aprendizes com médias de escores referentes ao conhecimento produtivo (3, 4 e 5) com média nas intervenções superior à 8 , o que nos leva a questionar a validade desse resultado na prática. 
Diante da possibilidade de a análise estatística não ter considerado nuances e manifestações decisivas para as conclusões desta pesquisa, optamos por realizar uma análise das respostas escritas dos testes. Os pontos observados foram:

1) A quantidade de respostas escritas e com escore 5 é superior no GE.

Os participantes do GE aprenderam as palavras-alvo em chunks. Segundo a AL, isso estimula a organização do léxico mental em blocos, facilitando o posterior processo de recuperação das palavras e evita combinações não usuais.

2) Os erros de construção (supressão ou troca de partícula e inversão sintática) no GE foram proporcionalmente menores que no GC. Uma possível explicação é que aprender o vocabulário em chunks favorece a aprendizagem da gramática da língua-alvo, pois itens lexicais de multipalavras possuem uma organização interna que expõe a estrutura da língua.

3) Os erros de tradução foram superiores no GC. As palavras-alvo do teste foram apresentadas ao GE durante as aulas do experimento como parte de colocações livres e expressões fixas e semifixas. Consequentemente, os participantes desse grupo podem ter formado uma rede maior de associações que facilitou a recuperação das palavras.

4) O GE apresentou produções escritas com o uso de palavras-alvo inseridas em expressões fixas e semifixas, fato não ocorrido na mesma proporção no GC. A única expressão fixa que também apareceu nas respostas do GC foi "Dôyatte ikimasuka".

5) O GE apresentou respostas com o uso das polipalavras basu noriba (ponto de ônibus) e takushî noriba (ponto de táxi), mas o mesmo não foi registrado em nenhuma das repostas do GC. Uma possível explicação pode ser o fato de que no GE a atenção dos aprendizes estava direcionada para a presença de itens lexicais no vocabulário novo.

6) No GE não houve concentração de respostas em poucos participantes, ao passo que no GC mais da metade das respostas foram dadas por apenas dois participantes. O desempenho no GE foi mais homogêneo, podendo inferir que o ganho de conhecimento lexical desse grupo pode estar relacionado com as intervenções baseadas na $\mathrm{AL}$ e não com a atuação excepcional de um ou outro aprendiz que elevou a média do grupo. 
Embora não haja comprovação estatística, excluímos a hipótese de que o desempenho superior do GE seja obra do acaso ou efeito de outras variáveis, com base nas observações resultantes da análise das respostas. Ao nosso ver, essas constituem forte evidência de que as produções do GE são quantitativa e qualitativamente melhores às do GC em função das intervenções baseadas na AL.

Com base nos resultados dos testes estatísticos e nas observações da análise das respostas escritas concluímos que complementar a aquisição incidental de vocabulário com o ensino sistematizado e explícito norteado pelos princípios da AL contribuiu para o desenvolvimento da competência lexical do aprendiz de LJ. A hipótese verificada pelo experimento é válida para o perfil de aprendiz e contexto de ensino contemplados.

Por fim, no que se refere às contribuições deste trabalho, consideramos que a discussão aqui proposta estimula professores e aprendizes a repensarem o papel do léxico e as formas de se aprender/ensinar novas palavras em japonês e estabelece uma discussão teóricoconceitual sobre a prática do ensino de LJ como LE, colaborando com o enriquecimento da bibliografia relacionada ao assunto.

\subsection{Limitações do estudo}

Ao longo da pesquisa, identificamos algumas limitações que consideramos importante mencionar. A primeira diz respeito à duração do experimento. Apesar de considerarmos válido todo o percurso metodológico e relevantes todas as conclusões finais, acreditamos que um estudo longitudinal traria dados mais robustos e representativos da relação entre o desenvolvimento da competência lexical dos aprendizes e a AL, uma vez que a aprendizagem tem caráter processual e não linear.

A segunda limitação está em parte relacionada com a primeira. Por se tratar de um estudo de curta duração e limitado a um público específico, não podemos generalizar os resultados. A confirmação da hipótese se restringe ao perfil de aprendiz e contexto de ensino contemplados no experimento.

A terceira e última limitação observada diz respeito à ausência de testes de vocabulário adequados para a avaliação de línguas com sistemas de escrita não alfabéticos. Utilizamos o VKS, mas tivemos que realizar adaptações e abrir mão de avaliar o conhecimento da forma da palavra. 


\section{REFERÊNCIAS BIBLIOGRÁFICAS}

AKAMINE, A. A instrução para processamento e a atividade de consciousness raising no ensino das flexões dos adjetivos em língua japonesa. 2012. 223f. Dissertação (Mestrado em Língua Japonesa) - Faculdade de Filosofia, Letras e Ciências Humanas, Universidade de São Paulo, São Paulo, 2012.

ALMEIDA FILHO, J. C. P. D. Dimensões comunicativas no ensino de línguas. Campinas: Pontes, 1993.

BARREIROS, M. O enriquecimento lexical através da hora do conto. 2014. 110f. Dissertação (Mestrado em Educação) - Instituto Politécnico de Viseu, Escola Superior de Educação de Viseu, Viseu, Portugal, 2014.

BIDERMAN, M. T. C. O conhecimento, a terminologia e o dicionário. Cien. Cult, v. 58, n. 2, 2006.

Teoria linguística. 2. ed. São Paulo: Martins Fontes, 2001.

BLOOMFIELD, L. A Set of Postulates for the Science of Language. Language, v. 2, n. 3, p. 153-164, 1926.

Language. Allen and Unwin: London, 1933.

BONI, V. F. C. V. Aprendizagem/aquisição de vocabulário em língua estrangeira: um estudo de caso sobre estratégias de aprendizagem. 2003. 164f. Dissertação (Mestrado em Letras) - Setor de Ciências Humanas, Letras e Artes, Universidade Federal do Paraná, Curitiba, 2003.

BRUTON, A. The Vocabulary Knowledge Scale: a critical analysis. Language Assessment Quarterly, v. 6, p.288-297, 2009.

BUNKACHÔ. Jôyô kanji hyô.

http://kokugo.bunka.go.jp/kokugo_nihongo/joho/kijun/naikaku/kanji/. Acessado em 06 de dezembro de 2016.

CAMPBELL, D.T.; STANLEY, J.C. Delineamentos experimentais e quase-experimentais de pesquisa. São Paulo: USP/EPU, 1979.

CANALE, M. From communicative competence to communicative language pedagogy. In: RICHARDS, J. C.; SCHMIDT, R. W. (Org). Language and Communication. London: Longman, 1983, p.2-27.

CANALE, M.; SWAIN, M. Theoretical bases of communicative approaches to second language teaching and testing. Applied Linguistics, Oxford, v. 1, n.1, p.1-47, 1980.

CANDLIN, C.N. Preface. In: CARTER, R.; MCCARTHY, M. Vocabulary and language teaching. New York: Routledge, 1988.

CELCE-MURCIA, M.; DORNYEI, Z.; THURRELL, S. Communicative competence: a pedagogically motivated model with contents specifications. Applied Linguistics, v. 6, n. 2, p.5-35, 1995.

CHOMSKY, N. The acquisition of syntax in children from five to ten. Cambridge: MIT Press, 1969.

. Aspects of the theory of syntax. Massachusetts: MIT Press, 1965.

CHOMSKY, N.; HALLE, M. The sound pattern of English. New York: Harper Row, 1968.

CHÛÔ KYÔIKU KENKYÛJO. Gakushû kihon goi. Tôkyô: Chûô kyôiku kenkyûjo, 1984.

CLAIBORNE, R. Our marvelous native tongue: the life and times of the English language. New York: Time books, 1983.

COADY, J. L2 Vocabulary acquisition - a synthesis of the research. In: COADY, J.; HUCKIN, T. (Org). Second language vocabulary acquisition: a rationale for pedagogy. Cambridge: Cambridge University Press, 1997, p. 225-237.

COOK, V. J.; BASSETTI, B. Second language writing systems. Clevedon: Multilingual Matters, 2005.

CRYSTAL, D. The English language. London: Penguin, 1988.

DEESE, J. The structure of associations in language and thought. Baltimore: John Hopkins Press, 1965.

DOI, E. T. A interferência fonológica no português falado pelos japoneses na região de Campinas (SP). 1983. 191f. Dissertação (Mestrado em Linguística) - Instituto de Estudos da Linguagem, Universidade Estadual de Campinas, Campinas, 1983.

ELLIS, R. Factors in the incidental acquisition of second language vocabulary from oral input: a review essay.

Applied Language Learning, v. 5, n. 1, p. 1-32, 1994. 
$441,1995$.

Modified oral input and the acquisition word meanings. Applied Linguistics, v. 16, n. 4, p. 401-

FEIJOO, A. M. L. C. A pesquisa e a estatística na psicologia e na educação. Rio de Janeiro: Bertrand Brasil, 1996.

FUKASAWA, L; GIROUX, S.; SUZUKI, Tae; SUZUKI, Teiiti. Introdução à gramática da língua japonesa. 2. ed. São Paulo: Centro de Estudos Japoneses da USP, 2001.

FUNDAÇÃO JAPÃO. Ensino de língua japonesa escolas e cursos: ensino fundamental, médio e superior. São Paulo, 2015.2 Disponível em http://fjsp.org.br/site/wpcontent/uploads/2015/06/Dados_ensino_lingua_japonesa_2014_ok.pdf.

GASS, S.; SELINKER, L. Second Language Acquisition: An Introductory Course. Hillsdale: Lawrence Erlbaum, 1994.

GATTOLIN, S.R.B O vocabulário na sala de aula de língua estrangeira: contribuições para a elaboração de uma teoria de ensino-aprendizagem. 2005. 402f. Tese (Doutorado em Linguística Aplicada) - Instituto de Estudos da Linguagem, Universidade Estadual de Campinas, Campinas, 2005.

HEDGE, T. Teaching and learning in the language classroom. Oxford: Oxford University Press, 2000.

HOSOKAWA, H. Nihongo kyôiku to kokugo kyôiku: bogo-dai 2 gengo no renkei to kadai (kyôkai o koeru nihongo kyôiku). Nihongo kyôiku, n. 100, p. 57-66, 1999.

HUCKIN, T.; COADY, J. Incidental vocabulary acquisition in a second language: a review. Studies in Second Language Acquisition, v. 21, n. 2, p. 181-193, 1999.

HULSTIJN, J.H. Intentional and incidental second-language vocabulary learning: A reappraisal of elaboration, rehearsal and automaticity. In: ROBINSON, P. (Org). Cognition and second language instruction. Cambridge: Cambridge University Press, 2001, p. 258-286.

HUOT, R. Métodos quantitativos para as ciências humanas. Lisboa: Instituto Piaget, 2002.

HYMES, D. On Communicative competence. In: PRIDE, J. P.; HOLMES, J. (Org). Sociolinguistics. Harmondsworth: Penguin, 1972, p. 269-293.

IKEHARA, N. Kokugo kyôiku no tame no kihon goi taikei. 1957.

ITO, Y. Ensino de língua japonesa no Núcleo de Línguas Estrangeiras da UECE: análise da produção oral dos professores e proposta de atividade didática. 2010. 197f. Dissertação (Mestrado em Linguística Aplicada) Centro de Humanidades, Universidade Estadual do Ceará, Fortaleza, 2010.

JAPAN FOUNDATION. JF Standart for Japanese Language Education, 2010. Disponível em https://jfstandard.jp/pdf/jfs2010_all_en.pdf/. Acessado em 2 de abril de 2014.

Editora.

Survey report on japanese-language education abroad 2012. Tôkyô: Japan: Kurosio

Marugoto: Nihon no Kotoba To Bunka - Katsudô - A1. Tôkyô, Japan: Sanshûsha, 2013.

Marugoto: Nihon no Kotoba To Bunka - Rikai - A1. Tôkyô, Japan: Sanshûsha, 2013.

JIANG, N. Lexical representation and development in a second language. Applied Linguistics, v. 21, n. 1, p. 47 $-77,2000$.

JIDÔ GENGO KENKYÛKAI. Gengo yôso shidô. Tôkyô: Meiji Tosho, 1962.

JOE, A. What effects do text-based tasks promoting generation have on vocabulary acquisition? Applied Linguistics, v. 19, n. 3, p. 357-377, 1998.

KATSUDA, K. Gendai kokugojiten no tokushoku. Departmental Bulletin Paper. Yamaguchiken: Toua Daigaku, 2010.

KIJIMA, H.; TOMOYO, S.; HATTA, N. JF Nihongo kyôiku sutandâdo junkyo kôsu bukkuno kaihatsu. Kokusai kyôryû kikin nihongo kyoiku kiyô, v. 8, p. 103-117, 2012.

KIKUCHI, W. Formação de palavras (I): prefixos. In: MORALES, L.M. (Org.). Tópicos de gramática em língua japonesa, São Paulo: Fundação Japão, 2011. 
Formação de palavras (II): sufixos. In: MORALES, L.M. (Org). Tópicos de gramática em língua japonesa, São Paulo: Fundação Japão, 2011.

KOKURITSU KOKUGO KENKYÛJO. Goi chôsa - Gendai shinbun yôgo no ichiretsu. Nihon: Shuei shuppan, 1952.

Bunruigoi. 1964.

Kyôiku kihon goi no kihonteki kenkyû - Zôho kaichôban, 2009.

Nihongo kihon goi bunken kaidai to kenkyû. Kokuritsu kokugo kenkyû hôkoku, n.116, 2000.

Nihongo Kyôiku no tame no kihon goi chôsa, 1984.

KOKUSAI BUNKA SHINKÔ KAI. Nihongo kihon goi, 1944.

KOKUSAI KÔRYÛ KIKIN. Moji goi o oshieru. Tôkyô: Hitsuji Shobô, 2011.

KRASHEN, S. D. We acquire vocabulary and spelling by reading: Additional evidence for the input hypothesis. Modern Language Journal, v. 73, p. 440-464, 1989.

KRASHEN, S. D; TERREL, D. T. The natural approach: language acquisition in the classroom. Hayward: Alemany Press, 1983.

KUCERA, H; FRANCIS, N.W. The computational analysis of present-day American English. Providence: Brown University Press, 1967.

LARSEN-FREEMAN, D. Techniques and principles in language teaching. 2.ed. Oxford: Oxford University Press, 2003.

LAUFER, B. What's in a word that makes it hard or easy: some intralexical factors that affect the learning of words. In: SCHMITT, N.; McCARTHY, M. (Org). Vocabulary: description, acquisition and pedagogy. Cambridge: Cambridge University Press, 1997.

LEECH, G. N. Semantics. 2. ed. Harmondsworth: Penguin, 1981.

LEFFA, V. J. Aspectos externos e internos da aquisição lexical. In: LEFFA, V. J. (Org.). As palavras e sua companhia: o léxico na aprendizagem. Pelotas: Editora da Universidade Católica de Pelotas, 2000, p. 15-44.

LEVELT, W. J. M. Speaking: from intention to articulation. Cambridge: Bradford, 1989.

LEWIS, M. The lexical approach: the state of ELT and the way forward. England: Language Teaching Publications, 1993. Publications, 1997.

Implementing the lexical approach: putting theory into practice. England: Language Teaching

LUYTEN, S. Onomatopeias e mimeses no manga: a estética do som. Revista USP, n. 52, p.176-188, 2002.

MAEKAWA, K. Design of a Balanced Corpus of Contemporary Written Japanese. In: Proceedings of the Symposium on Large-Scale Knowledge Resources, p. 55-58, 2007. Disponível em http://www2.ninjal.ac.jp/kikuo/LKR2007KM.pdf. Acessado em 20 de outubro de 2016.

MARQUES, A. C. H. O poder das estatísticas: Ensaio sobre a interpretação da realidade. Economia \& Pesquisa, v.1, n.1, p.51-60, 1999.

MARQUES, M.H.M. Reflexões didático-metodológicas para um ensino sistematizado do léxico em francês como língua estrangeira. 2012. 193f. Dissertação (Mestrado em Teorias Linguísticas do Léxico) - Instituto de Letras, Universidade Federal do Rio Grande do Sul, Porto Alegre, 2012.

MASAHIRO, O. Nihongo Onomatope Jiten. Tôkyô: Shôgakkan, 2007.

MATSUDA, M; KODAMA, S.; TAKEMOTO, Y.; ISHIZAKA, T.; MORI, A.; KAWAMURA, Y.; YAMAMOTO, W. Kôpasu no kotonari to tango shinmitsudo o katsuyô shita nihongo kyôtsô kiso goi no chûshutsu. Gengo shori gakkai dai 14 kai nenji taikai happyô ronbunshû, p. 579-582, 2010.

MEARA, P. The dimensions of lexical competence. In: BROWN, G; MALMKJAER, K.; WILLIAMS, J. (Org). Performance and competence in second language acquisition. Cambridge: Cambridge University Press, 1996, p. 35-53.

Vocabulary acquisition: a neglected aspect oflanguage learning. Language. Teaching $\boldsymbol{\&}$

Linguistics Abstracts, v. 13, p. 221-246, 1980. 
. The study of lexis in interlanguage. In: DAVIS, A. et al. (Org.). Interlanguage. Edinburgh: Edinburgh University Press, 1984, p. 225-235.

MINISTRY OF EDUCATION, CULTURE, SPORTS, SCIENCE AND TECHOLOGY JAPAN. School systems. Disponível em 〈http://www.mext.go.jp/english/introduction/1303952.htm〉. Acesso em: 18 de março de 2016.

MORALES, L. M. Cem anos de imigração japonesa no Brasil: o japonês como língua estrangeira. 2008. 326f. Tese (Doutorado em Linguística) - Faculdade de Filosofia, Ciências e Letras, Universidade de São Paulo, São Paulo, 2008.

. Variação linguística de professores de língua japonesa do Brasil: estudo linguístico tendo em vista os efeitos no ensino-aprendizagem como língua estrangeira. In: MUKAI, Y; JOKO, A. T.; PEREIRA, F. P. (orgs.). A língua japonesa no Brasil: reflexões e experiências de ensino e aprendizagem. Coleção Japão em Foco - Volume 1, Campinas, SP: Pontes Editores, 2012.

MORIWAKI, R; NAKATA, M. História do Ensino da Língua Japonesa no Brasil. Campinas: Editora Unicamp, 2008.

MOTTA, D. F. Método relacional como nova abordagem para construção de tesauros. Coleção Albano Franco, n.12, Rio de Janeiro: SENAI, 1987.

MUKAI, Y; JOKO, A. T.; PEREIRA, F. P. (orgs.). A língua japonesa no Brasil: reflexões e experiências de ensino e aprendizagem. Coleção Japão em Foco - Volume 1, Campinas, SP: Pontes Editores, 2012.

NAGY, W. E.; HERMAN, P. A. Incidental vs. instructional approaches to increasing reading vocabulary. Educational Perspectives, v. 23, p. 16-21, 1985.

NASSAJI, H. The relationship between depth of vocabulary knowledge and L2 learners' lexical inferencing strategy use and success. Canadian Modern Language Review, v. 61, p. 107-134, 2004.

NATION, I. S. P. Learning vocabulary in another language. 2. ed. Cambridge: Cambridge University Press, 2013.

NATION, I. S. P. Teaching and Learning Vocabulary. Massachusetts: Heinle \& Heinle Publishers, 1990.

NATIONAL INSTITUTE FOR JAPANESE LANGUAGE AND LIGUISTICS. Balanced Corpus of Contemporary Written Japanese, 2012. Disponível em //www.ninjal.ac.jp/english/products/bccwj/. Acessado em 12 de abril de 2014.

OLIVEIRA, A. W. M. É assim que eu escrevo: estratégias de aprendizagem de kanji e crenças de professores de língua japonesa. 2013. 179f. Dissertação (Mestrado em Linguística) - Departamento de Línguas Estrangeiras e Tradução, Universidade de Brasília, Brasília, 2013.

OSGOOD, C. E.; SUCI, G. J.; TANNENBAUM, P. H. The measurement of meaning. Urbana: University of Illinois Press, 1957.

OTA, J. Formação de palavras e as palavras compostas da língua japonesa. In: MORALES, L.M. (Org). Tópicos de gramática em língua japonesa. São Paulo: Fundação Japão, 2011.

OXFORD, R.; D. CROOKALL. Vocabulary Language: A critical Analysis of Teaching. TESL Canada Journal, v. 7, n. 2, p. 9-30, 1990.

PARIBAKHT, T. S.; WESCHE, M. Vocabulary enhancement activities and reading for meaning in second language vocabulary. In: COADY, J.; HUCKIN, T. (Org). Second language vocabulary acquisition: a rationale for pedagogy. Cambridge: Cambridge University Press, 1997.

PARIBAKHT, T. S; WESHE, M. Reading comprehension and second language development in a comprehension-basead ESL program. TESL Canada Journal, v. 11, p. 9-29, 1993.

PEREIRA, N. L. S. Música e texto: um estudo comparativo da aquisição de vocabulário em LE. 2006. 116f. Dissertação (Mestrado em Aquisição de Linguagem) - Instituto de Letras, Universidade Federal do Rio Grande do Sul, Porto Alegre, 2006.

YACHI, M. Dainigengo toshite no goi shûtoku kenkyû no gaikan: gakushû keinô, hôryaku no kanten kara. Gengo bunka to nihongo kyôiku. Zoukan tokushûgo, dainigengo shûtoku, kyôiku no kenkyû saizensen. Ochanomizu no daigaku: Tôkyô, p. 155-166, 2002.

READ, J. Assessing vocabulary. Cambridge: Cambridge University Press, 2000. 
REIS, E. Estatística descritiva. Lisboa: Edições Sílabo, 1996.

RICHARDS, J. C. The role of vocabulary teaching. Tesol Quarterly, v. 10, p.77-89, 1976.

RICHARDS, J; RODGERS, T.S. Approaches and methods in language teaching: description and analysis. New York: Cambridge University Press, 1986.

SAITO, F. B. Aprendizagem de vocabulário de inglês como língua estrangeira em ambiente hipermídia: efeitos da retenção lexical a curto e longo prazo em uma abordagem de ensino e aprendizagem lexical implícita. 2015. 149f. Tese (Doutorado em Linguística) - Faculdade de Letras, Universidade Federal de Juiz de Fora, Juiz de Fora, 2015.

SAKAMOTO, I. Kyôiku kihon goi. Tôkyô: Makishôten, 1958.

Nihongo kihon goi: yônen no bu. Nihon: Meiji Tosho, 1943.

Shinkyôiku kihon goi. Tôkyô: Gakugei tosho, 1984.

SCARAMUCCI, M. V. R. A competência lexical de alunos universitários aprendendo a ler em inglês como língua estrangeira. Delta, São Paulo: PUC-SP, v. 13, n. 2, 1997.

Apresentação. In: SCARAMUCCI, M. V. R.; GATTOLIN, S.R.B. (Org). Pesquisas sobre Vocabulário em Língua Estrangeira. Campinas: UNICAMP, 2007, p. 7-12.

O papel do léxico na compreensão em leitura em língua estrangeira: foco no produto e no processo. 1995. 357f. Tese (Doutorado em Linguística Aplicada) - Instituto de Estudos da Linguagem, Universidade Estadual de Campinas, Campinas, 1995.

SCHMIDT, R. W. The role of consciousness in second language learning. Applied Linguistics, v. 11, n. 2, 129$158,1990$.

SCHMITT, N.; McCARTHY, M. (Org). Vocabulary: description, acquisition and pedagogy. Cambridge: Cambridge University Press, 1997.

SCHMITT, N.; MEARA, P. M. Researching vocabulary through a word knowledge framework: word associations and verbal suffixes. Studies in Second Language Acquisition, v. 19, p.17-35, 1997.

SCOTT, M. R. Demystifying the jabberwocky: a research narrative. Tese (Doutorado) - Lancaster: University of Lancaster, 1990.

SHIMAMURA, N. Nihongo no kihongoi ni kansuru kenkyû. Kokugoken purojekutâ, v.3, n.3, p.133-141, 2013.

SILVA, E; OLIVEIRA, L. Impacto da leitura intensiva em língua inglesa no repertório lexical: uma análise quantitativa. Domínios de Lingu@gem, v. 10, n. 1, p. 380-406, 2016.

SINCLAIR, J. Corpus, concordance, collocation. Oxford: Oxford University Press, 1991.

SKINNER, B.F. The behavior of organisms: an experimental analysis. New York: Appleton-Century, 1938.

TAJIMA, K. Onomatope (giongo gitaigo) nitsuite. Nihongo kyôiku ronshû, v.16, p. 193-2005, 2006.

TAMAMURA, F. Goi kenkyû: nihongo no tango no shoseishitsu to goi no kyôiku. KOKUSAI KÔRYÛ KIKIN, Nihongo kyôiku tsûshin nihongo kyôiku o kenkyû suru, v. 7, p.10-11, 1998.

TAMURA, Y. Gendai nihongo no fukugô keiyôshi, haseigo, jôgo keiyôshi nitsuite. Hiroshima Daigaku Ryûgakusei Sentâ Kiyô, v. 16, p.16-20, 2006.

u.ac.jp/ja/00023014>. Acessado em 22 de maio de 2015.

Disponível em: <http://ir.lib.hiroshima-

TANAKA, H. Gakushû kihon goi. Tôkyô: Shinkô kakuten, 1956.

Shôgakkô no kokugo kyôkasho no goi, 1954.

TERRELL, T.D. A natural approach to the acquisition and learning of a language. Modern Language Journal, v. 61, p. 325-336, 1977.

THORNDIKE, E. L; LORGE, I. The teacher's word book of 30,000 words. New York: Teachers College Press, 1944.

TRÉVILLE, M.C. Vocabulaire et Apprentissage d'une langue Seconde. Québec: Les Éditions Logiques, 2000.

TRIOLA, M. F. Elementary statistics technology update.11. ed. Pearson Higher Ed, 2011. 
VERMEER, A. Breadth and depth of vocabulary in relation to L1/L2 acquisition and frequency of input. Applied Psycholinguistics, v. 22, n. 2, p. 217-234, 2001.

VILELA, M. Estudos de Lexicologia do Português. Coimbra: Amedina, 1994, p.1-20.

Estruturas léxicas do português. Coimbra: Livraria Almedina, 1979.

WESHE, M; PARIBAKHT, T. S. Assessing second language vocabulary knowledge: depth versus breadth. The Canadian Modern Language Review, v. 53, 1996, p.13-40.

WESHE, M; PARIBAKHT, T. S. Vocabulary enhancement activities and reading for meaning in second language vocabulary acquisition. In: COADY, J.; HUCKIN, T. (Org). Second language vocabulary acquisition: a rationale for pedagogy. Cambridge: Cambridge University Press, 1997, p. 174-200.

WEST, M. A general service list of English words. London: Longman, 1953.

WILKINS, D. A. Notional syllabuses. Oxford: Oxford University Press, 1976.

ZYLLES, M. O ensino e a aquisição de vocabulário em contexto de instrução de língua estrangeira. 2001. 192f. Dissertação (Mestrado em Estudos da Linguagem) - Universidade Federal do Rio Grande do Sul, Porto Alegre, 2001.

ZIMMERMAN, C. B. Historical trends in second language vocabulary instruction. In: COADY, J.; HUCKIN, T. anexo a(Org). Second language vocabulary acquisition: a rationale for pedagogy. Cambridge: Cambridge University Press, 1997, p. 5-19. 
ANEXO A - What is involved in knowing a word

\begin{tabular}{|c|c|c|c|}
\hline FORM & $\begin{array}{l}\text { Spoken } \\
\text { Written } \\
\text { Words parts }\end{array}$ & $\begin{array}{l}\mathrm{R} \\
\mathrm{P} \\
\mathrm{R} \\
\mathrm{P} \\
\mathrm{R} \\
\mathrm{P}\end{array}$ & $\begin{array}{l}\text { What does the word sound like? } \\
\text { Qual é a aparência da palavra? } \\
\text { What does the word look like? } \\
\text { How is the word written and spelled? } \\
\text { What parts are recognizable in this word? } \\
\text { What word parts are needed to express the meaning? }\end{array}$ \\
\hline MEANING & $\begin{array}{l}\text { Form and } \\
\text { meaning } \\
\text { Concept and } \\
\text { referents } \\
\text { Associations }\end{array}$ & $\begin{array}{l}\mathrm{R} \\
\mathrm{P} \\
\mathrm{R} \\
\mathrm{P}\end{array}$ & $\begin{array}{l}\text { What meaning does this word form signal? } \\
\text { What word form can be used to express this } \\
\text { meaning? } \\
\text { What is included in the concept? } \\
\text { What items can the concept refer to? } \\
\text { What other words does this make us think of? } \\
\text { What other words could we use instead of this one? }\end{array}$ \\
\hline USE & $\begin{array}{l}\begin{array}{l}\text { Grammatical } \\
\text { functions }\end{array} \\
\text { Collocations } \\
\text { Constraints } \\
\text { on use } \\
\text { (register, } \\
\text { frequency ...) }\end{array}$ & $\begin{array}{l}\mathrm{R} \\
\mathrm{P} \\
\mathrm{R} \\
\mathrm{P}\end{array}$ & $\begin{array}{l}\text { In what patterns does the word occur? } \\
\text { In what patterns must we use this word? } \\
\text { What words or types of words occur with this one? } \\
\text { What words or types of words must we use with this } \\
\text { one? } \\
\text { Where, when, and how often would we expect to } \\
\text { meet this word? } \\
\text { Where, when, and how often can we use this word? }\end{array}$ \\
\hline
\end{tabular}

(NATION, 2013, p. 49) 
ANEXO B - Imagens utilizadas na primeira intervenção

\section{Imagem A}

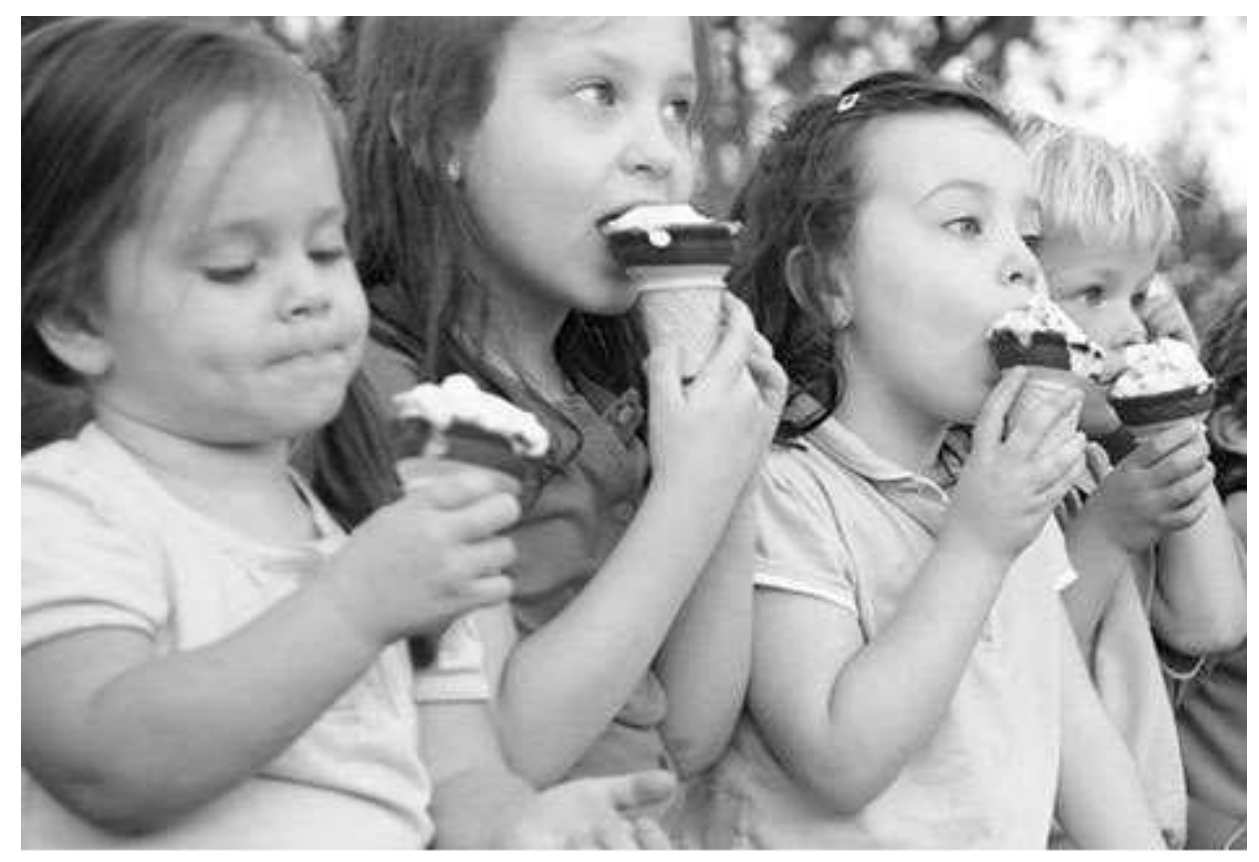

\section{Imagem B}

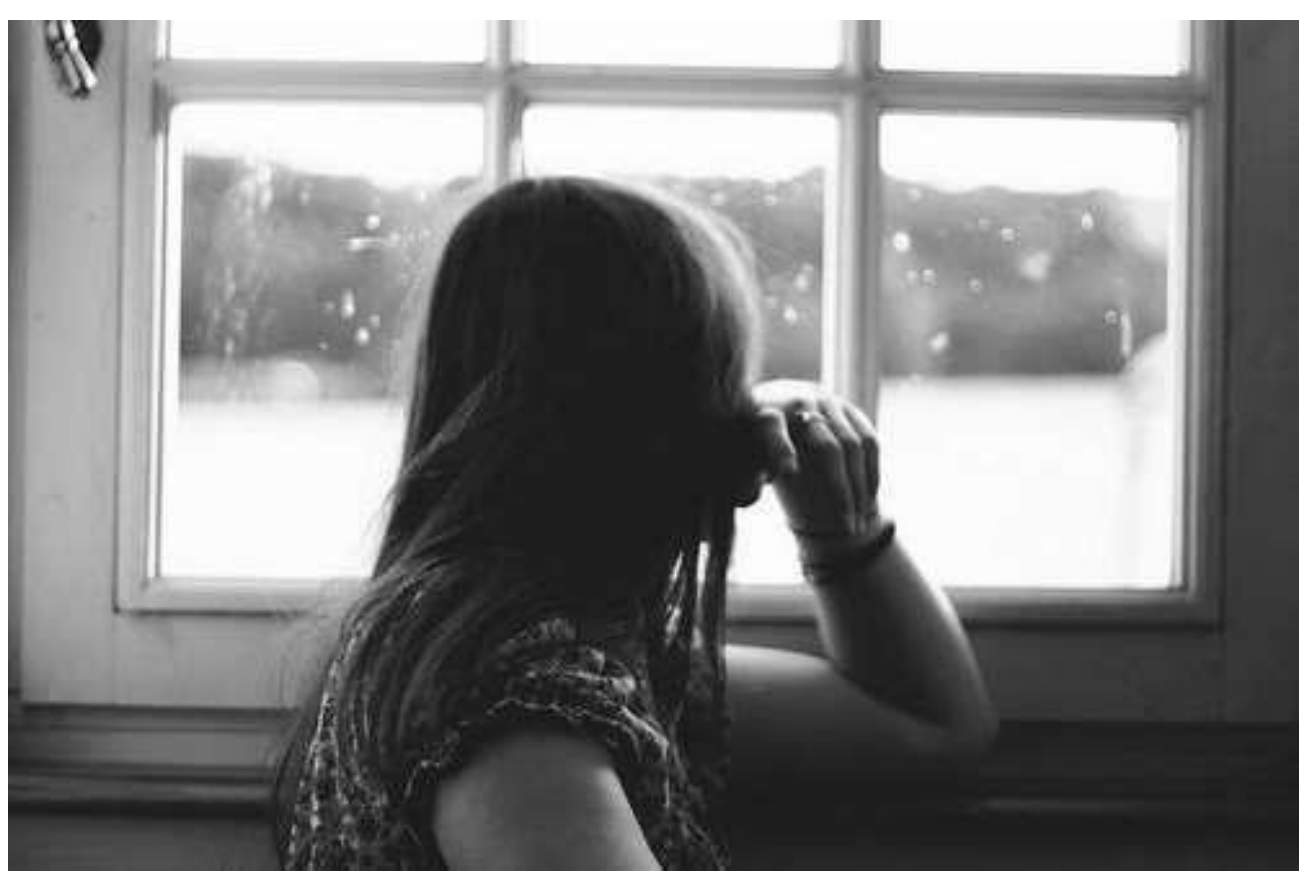




\section{ANEXO C - Teste de Familiaridade}

\section{Pré-teste I - Familiaridade}

Nome:

$\mathrm{N}^{\mathrm{o}}\left({ }^{\prime}\right)$ Data:

Indique, na escala de 1 a 4 que segue, seu grau de familiaridade com cada uma das palavras abaixo.

1. Eu nunca vi essa palavra antes.

2. Eu já vi essa palavra antes, mas não sei o que quer dizer.

3. Eu já vi essa palavra antes e acho que significa.... (escrever na última coluna).

4. Eu conheço essa palavra. Eu sei o que ela quer dizer (escrever na última coluna).

\begin{tabular}{|c|c|c|c|c|c|c|c|}
\hline & PAL & IVRA & 1 & 2 & 3 & 4 & $\begin{array}{c}\text { Correspondente em } \\
\text { LP }\end{array}$ \\
\hline 1 & おそい & (osoi) & & & & & \\
\hline 2 & ひこうき & (hikouki) & & & & & \\
\hline 3 & たぶん & (tabun) & & & & & \\
\hline 4 & カード & (kaado) & & & & & \\
\hline 5 & とおい & (tooi) & & & & & \\
\hline 6 & くうこう & (kuukou) & & & & & \\
\hline 7 & バス & (basu) & & & & & \\
\hline 8 & $5<$ & $($ raku $)$ & & & & & \\
\hline 9 & よ゙うやって & (douyatte) & & & & & \\
\hline 10 & えき & (eki) & & & & & \\
\hline 11 & ゆうめい & (yuumei) & & & & & \\
\hline 12 & いきます & (ikimasu) & & & & & \\
\hline 13 & ちず & (chizu) & & & & & \\
\hline 14 & おります & (orimasu) & & & & & \\
\hline 15 & で & (de) & & & & & \\
\hline 16 & かいます & (kaimasu) & & & & & \\
\hline 17 & ひくい & (hikui) & & & & & \\
\hline 18 & いい & (ii) & & & & & \\
\hline 19 & りょこうします & (ryoukoushimasu) & & & & & \\
\hline 20 & どこ & (doko) & & & & & \\
\hline 21 & まち & (machi) & & & & & \\
\hline 22 & うしろ & (ushiro) & & & & & \\
\hline 23 & ビル & (biru) & & & & & \\
\hline 24 & ベんり & (benri) & & & & & \\
\hline 25 & なか & (naka) & & & & & \\
\hline 26 & あるいて & (aruite) & & & & & \\
\hline 27 & です & (desu) & & & & & \\
\hline 28 & まっすぐ & (massugu) & & & & & \\
\hline 29 & デパート & (depaato) & & & & & \\
\hline 30 & のります & (norimasu) & & & & & \\
\hline
\end{tabular}




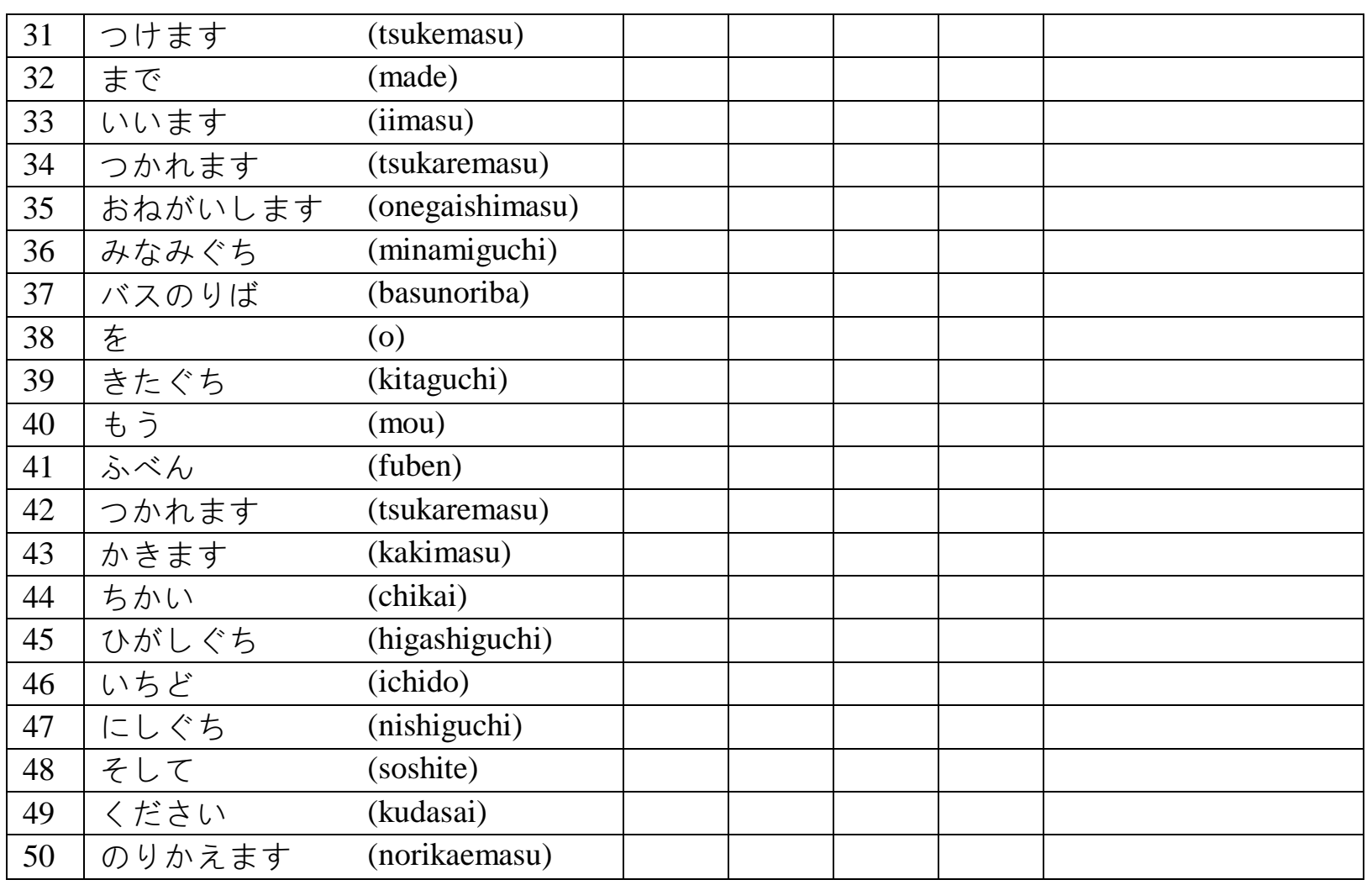




\section{ANEXO D - Pós-Teste Imediato (VKS)}

\section{Pós-Teste Imediato - VKS}

Nome:

Início: $\mathrm{H} \quad$ MIN $\mathrm{N}^{\mathrm{o}}(\underset{\text { TÉRMINO: }}{\text { D Data: }}$ l $\frac{1}{\mathrm{H}} \frac{}{\mathrm{MIN}}$

Tempo total:

Indique, na escala de 1 a 5 que segue, a alternativa que melhor representa o seu conhecimento em relação a cada uma das palavras abaixo.

1)のります

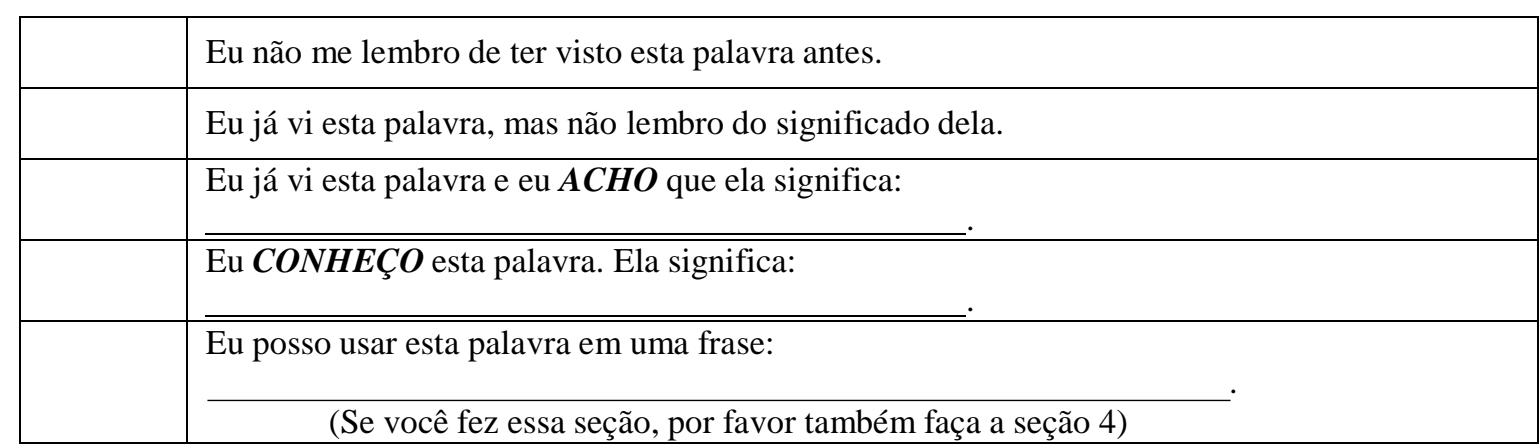

2) ちず

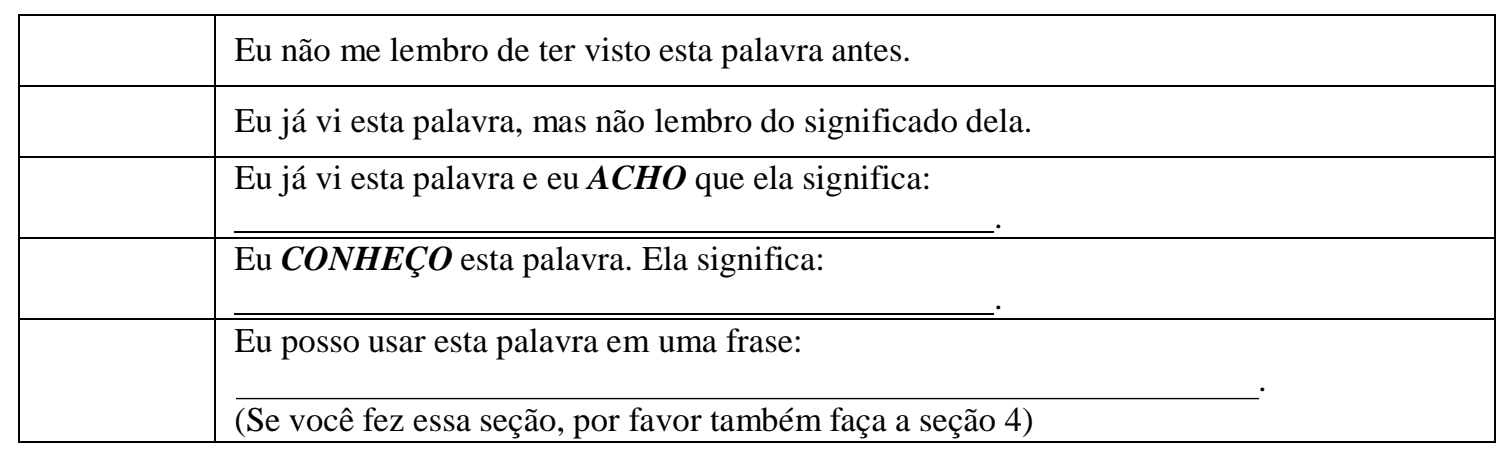

3) まっすぐ

\begin{tabular}{|l|l|}
\hline & Eu não me lembro de ter visto esta palavra antes. \\
\hline & Eu já vi esta palavra, mas não lembro do significado dela. \\
\hline & \begin{tabular}{l} 
Eu já vi esta palavra e eu $\boldsymbol{A C H O}$ que ela significa: \\
\hline
\end{tabular} \\
\hline & $\frac{\text { Eu posso usar esta palavra em uma frase: }}{(\text { Se você fez essa seção, por favor também faça a seção } 4)}$ \\
\hline
\end{tabular}


4) ベんり

\begin{tabular}{|l|l|}
\hline & Eu não me lembro de ter visto esta palavra antes. \\
\hline & Eu já vi esta palavra, mas não lembro do significado dela. \\
\hline & $\frac{\text { Eu já vi esta palavra e eu } \boldsymbol{A C H O} \text { que ela significa: }}{\text { Eu } \boldsymbol{C} \boldsymbol{C H E C} \boldsymbol{O} \text { esta palavra. Ela significa: }}$ \\
\hline & $\frac{\text { Eu posso usar esta palavra em uma frase: }}{\text { (Se você fez essa seção, por favor também faça a seção 4) }} \cdot$ \\
\hline
\end{tabular}

5) くうこう

\begin{tabular}{|l|l|}
\hline & Eu não me lembro de ter visto esta palavra antes. \\
\hline & Eu já vi esta palavra, mas não lembro do significado dela. \\
\hline & \begin{tabular}{l} 
Eu já vi esta palavra e eu $\boldsymbol{A C H O}$ que ela significa: \\
\hline
\end{tabular} \\
\hline & $\frac{\text { Eu posso usar esta palavra em uma frase: }}{(\text { Se você fez essa seção, por favor também faça a seção 4) }}$ \\
\hline
\end{tabular}

6) おります

\begin{tabular}{|l|l|}
\hline & Eu não me lembro de ter visto esta palavra antes. \\
\hline & Eu já vi esta palavra, mas não lembro do significado dela. \\
\hline & \begin{tabular}{l} 
Eu já vi esta palavra e eu $\boldsymbol{A C H O}$ que ela significa: \\
\hline
\end{tabular} \\
\hline & $\frac{\text { Eu posso usar esta palavra em uma frase: }}{(\text { Se você fez essa seção, por favor também faça a seção 4) }}$ \\
\hline
\end{tabular}

7) どうやって

\begin{tabular}{|l|l|}
\hline & Eu não me lembro de ter visto esta palavra antes. \\
\hline & Eu já vi esta palavra, mas não lembro do significado dela. \\
\hline & \begin{tabular}{l} 
Eu já vi esta palavra e eu $\boldsymbol{A C H O}$ que ela significa: \\
\hline
\end{tabular} \\
\hline & $\frac{\text { Eu posso usar esta palavra em uma frase: }}{(\text { Se você fez essa seção, por favor também faça a seção 4) }}$ \\
\hline
\end{tabular}


8) とおい

\begin{tabular}{|l|l|}
\hline & Eu não me lembro de ter visto esta palavra antes. \\
\hline & Eu já vi esta palavra, mas não lembro do significado dela. \\
\hline & \begin{tabular}{l} 
Eu já vi esta palavra e eu $\boldsymbol{A C H O}$ que ela significa: \\
\hline
\end{tabular} \\
\hline & $\begin{array}{l}\text { Eu posso usar esta palavra em uma frase: } \\
\text { (Se você fez essa seção, por favor também faça a seção 4) }\end{array}$ \\
\hline
\end{tabular}

9) ちかい

\begin{tabular}{|l|l|}
\hline & Eu não me lembro de ter visto esta palavra antes. \\
\hline & Eu já vi esta palavra, mas não lembro do significado dela. \\
\hline & \begin{tabular}{l} 
Eu já vi esta palavra e eu $\boldsymbol{A C H O}$ que ela significa: \\
\hline
\end{tabular} \\
\hline & $\begin{array}{l}\text { Eu posso usar esta palavra em uma frase: } \\
\text { (Se você fez essa seção, por favor também faça a seção 4) }\end{array}$ \\
\hline
\end{tabular}

10) ゆうめい

\begin{tabular}{|l|l|}
\hline & Eu não me lembro de ter visto esta palavra antes. \\
\hline & Eu já vi esta palavra, mas não lembro do significado dela. \\
\hline & Eu já vi esta palavra e eu $\boldsymbol{A C H O}$ que ela significa: \\
\hline & \begin{tabular}{l} 
Eu $\boldsymbol{C O N H E C ̧ O ~ e s t a ~ p a l a v r a . ~ E l a ~ s i g n i f i c a : ~}$ \\
\hline
\end{tabular} \\
\hline
\end{tabular}




\section{ANEXO E - Pós-Teste Postergado (VKS)}

\section{Pós-Teste Postergado - VKS}

Nome:

Início: H MIN $\mathrm{N}^{\mathrm{o}}(\ldots)$ Data: TÉRMINO: $1 \frac{1}{\mathrm{H}} \frac{}{\mathrm{MIN}}$

Tempo total:

Indique, na escala de 1 a 5 que segue, a alternativa que melhor representa o seu conhecimento em relação a cada uma das palavras abaixo.

1)のります

\begin{tabular}{|l|l|}
\hline & Eu não me lembro de ter visto esta palavra antes. \\
\hline & Eu já vi esta palavra, mas não lembro do significado dela. \\
\hline & \begin{tabular}{l} 
Eu já vi esta palavra e eu $\boldsymbol{A C H O}$ que ela significa: \\
\hline Eu $\boldsymbol{C O N H E C ̧ O ~ e s t a ~ p a l a v r a . ~ E l a ~ s i g n i f i c a : ~}$
\end{tabular} \\
\hline & $\frac{\text { Eu posso usar esta palavra em uma frase: }}{(\text { Se você fez essa seção, por favor também faça a seção 4) }}$ \\
\hline
\end{tabular}

2) ちず

\begin{tabular}{|l|l|}
\hline & Eu não me lembro de ter visto esta palavra antes. \\
\hline & Eu já vi esta palavra, mas não lembro do significado dela. \\
\hline & \begin{tabular}{l} 
Eu já vi esta palavra e eu $\boldsymbol{A C H O}$ que ela significa: \\
\hline
\end{tabular} \\
\hline $\begin{array}{l}\text { Eu } \boldsymbol{C O N H E C ̧ O ~} \text { esta palavra. Ela significa: } \\
\text { (Se você fez essa seção, por favor também faça a seção 4) }\end{array}$ \\
\hline
\end{tabular}

3) まっすぐ

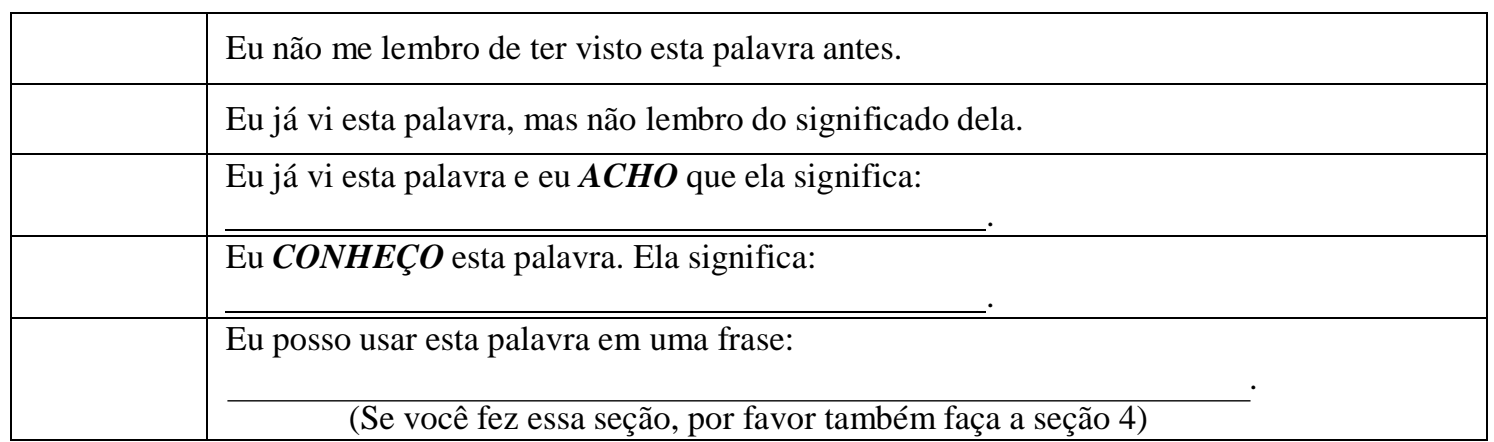


4) ベんり

\begin{tabular}{|l|l|}
\hline & Eu não me lembro de ter visto esta palavra antes. \\
\hline & Eu já vi esta palavra, mas não lembro do significado dela. \\
\hline & \begin{tabular}{l} 
Eu já vi esta palavra e eu $\boldsymbol{A C H O}$ que ela significa: \\
\hline
\end{tabular} \\
\hline & $\frac{\text { Eu posso usar esta palavra em uma frase: }}{(\text { Se você fez essa seção, por favor também faça a seção } 4)}$ \\
\hline
\end{tabular}

5) くうこう

\begin{tabular}{|l|l|}
\hline & Eu não me lembro de ter visto esta palavra antes. \\
\hline & Eu já vi esta palavra, mas não lembro do significado dela. \\
\hline & \begin{tabular}{l} 
Eu já vi esta palavra e eu $\boldsymbol{A C H O}$ que ela significa: \\
\hline
\end{tabular} \\
\hline & $\frac{\text { Eu posso usar esta palavra em uma frase: }}{(\text { Se você fez essa seção, por favor também faça a seção 4) }}$ \\
\hline
\end{tabular}

6) おります

\begin{tabular}{|l|l|}
\hline & Eu não me lembro de ter visto esta palavra antes. \\
\hline & Eu já vi esta palavra, mas não lembro do significado dela. \\
\hline & \begin{tabular}{l} 
Eu já vi esta palavra e eu $\boldsymbol{A C H O}$ que ela significa: \\
\hline
\end{tabular} \\
\hline & $\frac{\text { Eu posso usar esta palavra em uma frase: }}{(\text { Se você fez essa seção, por favor também faça a seção } 4)}$ \\
\hline
\end{tabular}

7) よ゙うやって

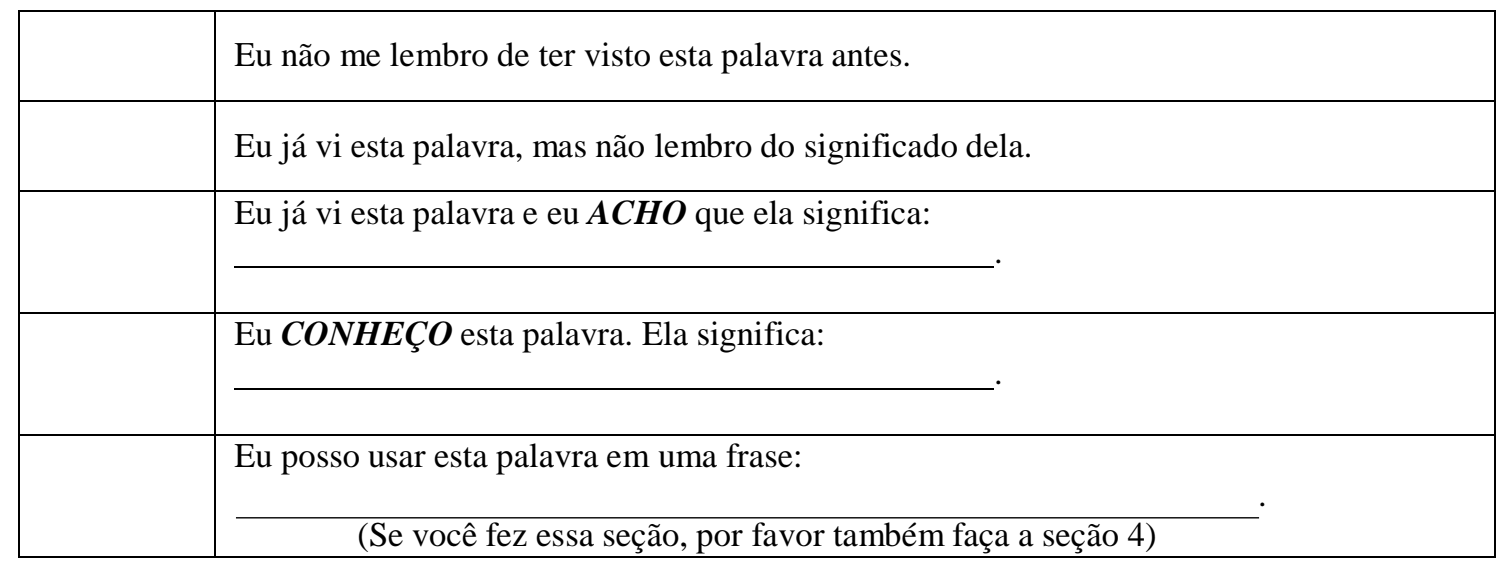


8) とおい

\begin{tabular}{|l|l|}
\hline & Eu não me lembro de ter visto esta palavra antes. \\
\hline & Eu já vi esta palavra, mas não lembro do significado dela. \\
\hline & \begin{tabular}{l} 
Eu já vi esta palavra e eu $\boldsymbol{A C H O}$ que ela significa: \\
\hline
\end{tabular} \\
\hline & $\frac{\text { Eu posso usar esta palavra em uma frase: }}{\text { (Se você fez essa seção, por favor também faça a seção 4) }}$ \\
\hline
\end{tabular}

9) ちかい

\begin{tabular}{|l|l|}
\hline & Eu não me lembro de ter visto esta palavra antes. \\
\hline & Eu já vi esta palavra, mas não lembro do significado dela. \\
\hline & \begin{tabular}{l} 
Eu já vi esta palavra e eu $\boldsymbol{A C H O}$ que ela significa: \\
\hline
\end{tabular} \\
\hline & $\begin{array}{l}\text { Eu posso usar esta palavra em uma frase: } \\
\text { (Se você fez essa seção, por favor também faça a seção 4) }\end{array}$ \\
\hline
\end{tabular}

10) ゆうめい

\begin{tabular}{|l|l|}
\hline & Eu não me lembro de ter visto esta palavra antes. \\
\hline & Eu já vi esta palavra, mas não lembro do significado dela. \\
\hline & \begin{tabular}{l} 
Eu já vi esta palavra e eu $\boldsymbol{A C H O}$ que ela significa: \\
\hline
\end{tabular} \\
\hline & $\begin{array}{l}\text { Eu posso usar esta palavra em uma frase: } \\
\text { (Se você fez essa seção, por favor também faça a seção 4) }\end{array}$ \\
\hline
\end{tabular}




\section{ANEXO F - Teste de Wilcoxon para duas amostras independentes}

Há diferença significativa entre a quantidade de palavras reconhecidas no pós-teste imediato do grupo explícito e do grupo controle?

\section{Grupo Experimental}

\begin{tabular}{lcl} 
Participante & Reconhecimento em \% & Rank \\
\hline P1 & $20,00 \%$ & 9 \\
P2 & $40,00 \%$ & 15 \\
P3 & $70,00 \%$ & 21 \\
P4 & $90,00 \%$ & 23 \\
P5 & $60,00 \%$ & 19 \\
P6 & $50,00 \%$ & 17 \\
P7 & $40,00 \%$ & 15 \\
P8 & $80,00 \%$ & 22 \\
P9 & $30,00 \%$ & 12 \\
P10 & $20,00 \%$ & 9 \\
P11 & $60,00 \%$ & 19 \\
P12 & $40,00 \%$ & 15 \\
\hline
\end{tabular}

\begin{tabular}{rrr} 
Médias & \multicolumn{1}{r}{$\begin{array}{r}\text { Rank } \\
\text { normal }\end{array}$} & \multicolumn{2}{r}{$\begin{array}{r}\text { Rank } \\
\text { certo }\end{array}$} \\
$0,000 \%$ & 1 & 3 \\
$0,00 \%$ & 2 & 3 \\
$0,00 \%$ & 3 & 3 \\
$0,00 \%$ & 4 & 3 \\
$0,00 \%$ & 5 & 3 \\
$10,00 \%$ & 6 & 6,5 \\
$10,00 \%$ & 7 & 6,5 \\
$20,00 \%$ & 8 & 9 \\
$20,00 \%$ & 9 & 9 \\
$20,00 \%$ & 10 & 9 \\
$30,00 \%$ & 11 & 12 \\
$30,00 \%$ & 12 & 12 \\
$30,00 \%$ & 13 & 12 \\
$40,00 \%$ & 14 & 15 \\
$40,00 \%$ & 15 & 15 \\
$40,00 \%$ & 16 & 15 \\
$50,00 \%$ & 17 & 17 \\
$60,00 \%$ & 18 & 19 \\
$60,00 \%$ & 19 & 19 \\
$60,00 \%$ & 20 & 19 \\
$70,00 \%$ & 21 & 21 \\
$80,00 \%$ & 22 & 22 \\
$90,00 \%$ & 23 & 23
\end{tabular}

\begin{tabular}{lcl} 
Participante & Reconhecimento em \% & Rank \\
\hline P1 & $0,00 \%$ & 3 \\
P2 & $60,00 \%$ & 19 \\
P3 & $30,00 \%$ & 12 \\
P4 & $10,00 \%$ & 6,5 \\
P5 & $0,00 \%$ & 3 \\
P6 & $10,00 \%$ & 6,5 \\
P7 & $0,00 \%$ & 3 \\
P8 & $30,00 \%$ & 12 \\
P9 & $0,00 \%$ & 3 \\
P10 & $20,00 \%$ & 9 \\
P11 & $0,00 \%$ & 3 \\
\hline
\end{tabular}

Grupo Controle

Hipóteses:

Ho = Não há diferenças significativas entre a quantidade de palavras reconhecidas no PTI pelos participantes de cada grupo.

$\mathrm{Hi}=$ Há diferenças significativas entre a quantidade de palavras reconhecidas no PTI pelos participantes de cada grupo.

$\begin{array}{llll}\text { n1 } & 12 & \mathrm{n} 2 & 11 \\ \text { R1 } & 196 & \mathrm{R} 2 & \\ \text { R=R1 } & 196 & \\ \text { Mi R } & 144 & \\ \text { Sigma R } & 16,24807681 & \\ \text { z } & 3,200378765 & \text { "+/-1,96” } \\ \text { z crítico (a 5\% de significância) } & & \\ \text { z > z crítico, então z está na região crítica do gráfico, logo a hipótese nula Ho é rejeitada. } & \\ \text { Logo, há diferencas sionificativas entre a quantidade de palavras reconhecidas pelos participantes cada grupo. }\end{array}$




\section{ANEXO G - Teste de Wilcoxon para duas amostras independentes}

Há diferença significativa entre a quantidade de palavras reconhecidas no pós-teste postergado do grupo explícito e do grupo controle?

Grupo Experimental

\begin{tabular}{lcl} 
Participante & Reconhecimento em \% & Rank \\
\hline P1 & $10,00 \%$ & 6 \\
P2 & $50,00 \%$ & 18 \\
P3 & $60,00 \%$ & 20,5 \\
P4 & $90,00 \%$ & 23 \\
P5 & $60,00 \%$ & 20,5 \\
P6 & $20,00 \%$ & 9 \\
P7 & $40,00 \%$ & 15,5 \\
P8 & $40,00 \%$ & 15,5 \\
P9 & $30,00 \%$ & 12,5 \\
P10 & $30,00 \%$ & 12,5 \\
P11 & $50,00 \%$ & 18 \\
P12 & $20,00 \%$ & 9 \\
\hline
\end{tabular}

$\begin{array}{rrr}\text { Médias } & \begin{array}{c}\text { Rank } \\ \text { normal }\end{array} & \begin{array}{r}\text { Rank } \\ \text { certo }\end{array} \\ 0,00 \% & 1 & 2,5 \\ 0,00 \% & 2 & 2,5 \\ 0,00 \% & 3 & 2,5 \\ 0,00 \% & 4 & 2,5 \\ 10,00 \% & 5 & 6 \\ 10,00 \% & 6 & 6 \\ 10,00 \% & 7 & 6 \\ 20,00 \% & 8 & 9 \\ 20,00 \% & 9 & 9 \\ 20,00 \% & 10 & 9 \\ 30,00 \% & 11 & 12,5 \\ 30,00 \% & 12 & 12,5 \\ 30,00 \% & 13 & 12,5 \\ 30,00 \% & 14 & 12,5 \\ 40,00 \% & 15 & 15,5 \\ 40,00 \% & 16 & 15,5 \\ 50,00 \% & 17 & 18 \\ 50,00 \% & 18 & 18 \\ 50,00 \% & 19 & 18 \\ 60,00 \% & 20 & 20,5 \\ 60,00 \% & 21 & 20,5 \\ 80,00 \% & 22 & 22 \\ 90,00 \% & 23 & 23 \\ & & \end{array}$

\begin{tabular}{lcl} 
Participante & Reconhecimento em \% & Rank \\
\hline P1 & $10,00 \%$ & 6 \\
P2 & $80,00 \%$ & 22 \\
P3 & $30,00 \%$ & 12,5 \\
P4 & $0,00 \%$ & 2,5 \\
P5 & $0,00 \%$ & 2,5 \\
P6 & $20,00 \%$ & 9 \\
P7 & $0,00 \%$ & 2,5 \\
P8 & $50,00 \%$ & 18 \\
P9 & $10,00 \%$ & 6 \\
P10 & $30,00 \%$ & 12,5 \\
P11 & $0,00 \%$ & 2,5 \\
\hline
\end{tabular}

Grupo Controle

Hipóteses:

Ho = Não há diferenças significativas entre a quantidade de palavras reconhecidas no PTP pelos participantes de cada grupo.

$\mathrm{Hi}=$ Há diferenças significativas entre a quantidade de palavras reconhecidas no PTP pelos participantes de cada grupo.

$\begin{array}{llll}\text { n1 } & 12 & \mathrm{n} 2 & 11 \\ \mathrm{R} 1 & 180 & \mathrm{R} 2 & \\ \mathrm{R}=\mathrm{R} 1 & 180 & & \\ \text { mi R } & 144 & \\ \text { Sigma R } & 16,24807681 & \text { “+/-1,96” } \\ \text { z } & 2,215646838 & \\ \text { z crítico (a 5\% de significância) } & & \\ \text { z }>\text { z crítico, então z está na região crítica do gráfico, logo a hipótese nula Ho é rejeitada. } & \\ \text { Logo, há diferenças significativas entre a quantidade de palavras reconhecidas pelos participantes cada grupo. }\end{array}$




\section{ANEXO H - Teste de Wilcoxon Pareado}

Há diferença significativa entre a quantidade de palavras reconhecidas no pós-teste imediato e no pós-teste postergado do grupo explícito?

\begin{tabular}{lrr}
\hline Participante & PTI & PTP \\
\hline P1 & $20 \%$ & $10 \%$ \\
P2 & $40 \%$ & $50 \%$ \\
P3 & $70 \%$ & $60 \%$ \\
P4 & $90 \%$ & $90 \%$ \\
P5 & $60 \%$ & $60 \%$ \\
P6 & $50 \%$ & $20 \%$ \\
P7 & $40 \%$ & $40 \%$ \\
P8 & $80 \%$ & $40 \%$ \\
P9 & $30 \%$ & $30 \%$ \\
P10 & $20 \%$ & $30 \%$ \\
P11 & $60 \%$ & $50 \%$ \\
P12 & $40 \%$ & $20 \%$ \\
\hline
\end{tabular}

Soma dos positivos

Soma negativos

\begin{tabular}{lllll}
\hline PTI & PTP & "diferença" d & Ranking de $|\mathbf{d}|$ & Ranking com sinal \\
\hline $20 \%$ & $10 \%$ & $-10 \%$ & 3 & -3 \\
$40 \%$ & $50 \%$ & $10 \%$ & 3 & 3 \\
$70 \%$ & $60 \%$ & $-10 \%$ & 3 & -3 \\
$90 \%$ & $90 \%$ & $0 \%$ & & \\
$60 \%$ & $60 \%$ & $0 \%$ & & \\
$50 \%$ & $20 \%$ & $-30 \%$ & 7 & -7 \\
$40 \%$ & $40 \%$ & $0 \%$ & & \\
$80 \%$ & $40 \%$ & $-40 \%$ & 8 & -8 \\
$30 \%$ & $30 \%$ & $0 \%$ & & \\
$20 \%$ & $30 \%$ & $10 \%$ & 3 & 3 \\
$60 \%$ & $50 \%$ & $-10 \%$ & 3 & -3 \\
$40 \%$ & $20 \%$ & $-20 \%$ & 6 & -6 \\
\hline
\end{tabular}

6

$-30$

$$
\begin{aligned}
& \mathrm{T}=6 \\
& \mathrm{n}=8
\end{aligned}
$$

Como $\mathrm{n}<30$, então o valor crítico de T está na tabela A-8 (TRIOLA, 2010, p. 762).

De acordo com a Tabela A-8 e com um nível de significância de 5\%, o "Valor Crítico" é 4.

Como nosso $\mathrm{T}=6$ é maior que o valor crítico 4, então NÃO podemos rejeitar a hipótese nula. Logo, não há diferenças significativas entre quantidade de palavras reconhecidas pelos participantes do grupo experimental no pós-teste imediato e no pós-teste postergado. 


\section{ANEXO I - Teste de Wilcoxon Pareado}

Há diferença significativa entre a quantidade de palavras reconhecidas no pós-teste imediato e no pós-teste postergado do grupo controle?

\begin{tabular}{lll}
\hline Participante & PTI & PTP \\
\hline P1 & $00 \%$ & $00 \%$ \\
P2 & $60 \%$ & $80 \%$ \\
P3 & $30 \%$ & $30 \%$ \\
P4 & $10 \%$ & $00 \%$ \\
P5 & $00 \%$ & $00 \%$ \\
P6 & $10 \%$ & $00 \%$ \\
P7 & $00 \%$ & $00 \%$ \\
P8 & $30 \%$ & $50 \%$ \\
P9 & $00 \%$ & $10 \%$ \\
P10 & $20 \%$ & $30 \%$ \\
P11 & $00 \%$ & $00 \%$ \\
\hline
\end{tabular}

Soma dos positivos

Soma negativos

\begin{tabular}{lllll}
\hline PTI & PTP & "diferença" d & Ranking de $|\mathbf{d}|$ & Ranking com sinal \\
\hline $00 \%$ & $00 \%$ & $10 \%$ & 3 & 3 \\
$60 \%$ & $80 \%$ & $20 \%$ & 6,5 & 6,5 \\
$30 \%$ & $30 \%$ & $0 \%$ & & \\
$10 \%$ & $00 \%$ & $-10 \%$ & 3 & -3 \\
$00 \%$ & $00 \%$ & $0 \%$ & & \\
$10 \%$ & $00 \%$ & $10 \%$ & 3 & 3 \\
$00 \%$ & $00 \%$ & $0 \%$ & & \\
$30 \%$ & $50 \%$ & $20 \%$ & 6,5 & 6,5 \\
$00 \%$ & $10 \%$ & $10 \%$ & 3 & 3 \\
$20 \%$ & $30 \%$ & $10 \%$ & 3 & 3 \\
$00 \%$ & $00 \%$ & $0 \%$ & & \\
\hline
\end{tabular}

25

$-3$
$\mathrm{T}=6$

$\mathrm{n}=7$

Como $\mathrm{n}<30$, então o valor critico de T está na tabela A-8 (TRIOLA, 2010, p. 762).

De acordo com a Tabela A-8 e com um nível de significância de 5\%, o "Valor Crítico" é 2.

Como nosso $\mathrm{T}=6$ é maior que o valor crítico 2 , então não podemos rejeitar a hipótese nula.

Logo, não há diferenças significativas entre quantidade de palavras reconhecidas pelos participantes do grupo controle no pós-teste imediato e no pós-teste postergado. 


\section{ANEXO J - Teste de Wilcoxon para duas amostras independentes}

Há diferença significativa entre a média dos escores do pós-teste imediato do grupo explícito e do grupo controle?

Grupo Experimental

\begin{tabular}{lcl}
\hline Participante & Média dos escores & Rank \\
\hline P1 & 2,3 & 9,5 \\
P2 & 3,1 & 16 \\
P3 & 4,1 & 21 \\
P4 & 4,4 & 23 \\
P5 & 3,5 & 19 \\
P6 & 3,2 & 17 \\
P7 & 2,6 & 13 \\
P8 & 4,2 & 22 \\
P9 & 2,8 & 14 \\
P10 & 2,3 & 9,5 \\
P11 & 3,4 & 18 \\
P12 & 2,9 & 15 \\
\hline
\end{tabular}

$\begin{array}{rrr}\text { Médias } & \begin{array}{c}\text { Rank } \\ \text { normal }\end{array} & \begin{array}{c}\text { Rank } \\ \text { certo }\end{array} \\ 1,7 & 1 & 1,5 \\ 1,7 & 2 & 1,5 \\ 1,8 & 3 & 4 \\ 1,8 & 4 & 4 \\ 1,8 & 5 & 4 \\ 1,9 & 6 & 6 \\ 2,0 & 7 & 7 \\ 2,3 & 8 & 9,5 \\ 2,3 & 9 & 9,5 \\ 2,3 & 10 & 9,5 \\ 2,3 & 11 & 9,5 \\ 2,4 & 12 & 12 \\ 2,6 & 13 & 13 \\ 2,8 & 14 & 14 \\ 2,9 & 15 & 15 \\ 3,1 & 16 & 16 \\ 3,2 & 17 & 17 \\ 3,4 & 18 & 18 \\ 3,5 & 19 & 19 \\ 3,6 & 20 & 20 \\ 4,1 & 21 & 21 \\ 4,2 & 22 & 22 \\ 4,4 & 23 & 23\end{array}$

\begin{tabular}{lcl} 
Participante & Média dos escores & Rank \\
\hline P1 & 1,8 & 4 \\
P2 & 3,6 & 20 \\
P3 & 2,3 & 9,5 \\
P4 & 2,0 & 7 \\
P5 & 1,7 & 1,5 \\
P6 & 1,9 & 6 \\
P7 & 1,8 & 4 \\
P8 & 2,4 & 12 \\
P9 & 1,8 & 4 \\
P10 & 2,3 & 9,5 \\
P11 & 1,7 & 1,5 \\
\hline
\end{tabular}

Hipóteses:

Ho = Não há diferenças significativas entre os grupos nas médias dos escores do PTI.

$\mathrm{Hi}$ = Há diferenças significativas entre os grupos nas médias dos escores do PTI.

$\begin{array}{llcr}\text { n1 } & 12 & \mathrm{n} 2 & 11 \\ \mathrm{R} 1 & 197 & \mathrm{R} 2 & \\ \mathrm{R}=\mathrm{R} 1 & 197 & & \\ \mathrm{mi} \mathrm{R} & 144 & \\ \text { Sigma R } & 16,2481 & & \\ \mathrm{z} & 3.26192 & \text { "+/-1,96” } \\ \text { z crítico (a 5\% de significância) } & & \\ \mathrm{z}>\mathrm{z} \text { crítico, então z está na região crítica do gráfico, logo a hipótese nula é rejeitada. } & \\ \text { Logo, há diferenças significativas entre os grupos nas médias dos escores do pós-teste imediato. }\end{array}$




\section{ANEXO K - Teste de Wilcoxon para duas amostras independentes}

Há diferença significativa entre a média dos escores do pós-teste postergado do grupo explícito e do grupo controle?

Grupo Experimental

\begin{tabular}{lcl}
\hline Participante & Média dos escores & Rank \\
\hline P1 & 2 & 6 \\
P2 & 3,1 & 18,5 \\
P3 & 3,5 & 20 \\
P4 & 4,7 & 23 \\
P5 & 3,7 & 21 \\
P6 & 2,5 & 12,5 \\
P7 & 2,6 & 14 \\
P8 & 3,1 & 18,5 \\
P9 & 2,7 & 15 \\
P10 & 2,1 & 9 \\
P11 & 2,9 & 17 \\
P12 & 2 & 6 \\
\hline
\end{tabular}

\begin{tabular}{rrr} 
Médias & $\begin{array}{c}\text { Rank } \\
\text { normal }\end{array}$ & \multicolumn{2}{c}{ certo } \\
1,5 & 1 & 1 \\
1,6 & 2 & 2 \\
1,7 & 3 & 3 \\
1,9 & 4 & 4 \\
2,0 & 5 & 6 \\
2,0 & 6 & 6 \\
2,0 & 7 & 6 \\
2,1 & 8 & 9 \\
2,1 & 9 & 9 \\
2,1 & 10 & 9 \\
2,2 & 11 & 11 \\
2,5 & 12 & 12,5 \\
2,5 & 13 & 12,5 \\
2,6 & 14 & 14 \\
2,7 & 15 & 15 \\
2,8 & 16 & 16 \\
2,9 & 17 & 17 \\
3,1 & 18 & 18,5 \\
3,1 & 19 & 18,5 \\
3,5 & 20 & 20 \\
3,7 & 21 & 21 \\
4,3 & 22 & 22 \\
4,7 & 23 & 23
\end{tabular}

Grupo Controle

\begin{tabular}{lcl} 
Participante & Média dos escores & Rank \\
\hline P1 & 2,1 & 9 \\
P2 & 4,3 & 22 \\
P3 & 2,5 & 12,5 \\
P4 & 1,9 & 4 \\
P5 & 1,7 & 3 \\
P6 & 2,2 & 11 \\
P7 & 1,5 & 1 \\
P8 & 2,8 & 16 \\
P9 & 2,0 & 6 \\
P10 & 2,1 & 9 \\
P11 & 1,6 & 2 \\
\hline
\end{tabular}

2

\section{Hipóteses:}

Ho = Não há diferenças significativas entre os grupos nas médias dos escores do PTI. $\mathrm{Hi}=$ Há diferenças significativas entre os grupos nas médias dos escores do PTI.
n1 12
R1 180,5
$\mathrm{R}=\mathrm{R} 1$
mi R 144
Sigma R $\quad 16,2481$
$\mathrm{Z} \quad 2.24642$
z crítico (a 5\% de significância) " $+/-1,96 "$

$\mathrm{n} 2 \quad 11$

z > z crítico, então z está na região crítica do gráfico, logo a hipótese nula é rejeitada.

Logo, há diferenças significativas entre os grupos nas médias dos escores do PTP. 


\section{ANEXO L - Teste de Wilcoxon Pareado}

Há diferença significativa entre a média dos escores do pós-teste imediato e do pósteste postergado do grupo experimental?

\begin{tabular}{lll}
\hline Participante & PTI & PTP \\
\hline P1 & 2,3 & 2 \\
P2 & 3,1 & 3,1 \\
P3 & 4,1 & 3,5 \\
P4 & 4,4 & 4,7 \\
P5 & 3,5 & 3,7 \\
P6 & 3,2 & 2,5 \\
P7 & 2,6 & 2,6 \\
P8 & 4,2 & 3,1 \\
P9 & 2,8 & 2,7 \\
P10 & 2,3 & 2,1 \\
P11 & 3,4 & 2,9 \\
P12 & 2,9 & 2 \\
\hline
\end{tabular}

\begin{tabular}{lllll}
\hline PTI & PTP & "diferença" d & Ranking de $|\mathbf{d}|$ & Ranking com sinal \\
\hline 2,3 & 2 & $-0,3$ & 4,5 & $-4,5$ \\
3,1 & 3,1 & 0 & & \\
4,1 & 3,5 & $-0,6$ & 7 & -7 \\
4,4 & 4,7 & 0,3 & 4,5 & 4,5 \\
3,5 & 3,7 & 0,2 & 2,5 & 2,5 \\
3,2 & 2,5 & $-0,7$ & 8 & -8 \\
2,6 & 2,6 & 0 & & \\
4,2 & 3,1 & $-1,1$ & 10 & -10 \\
2,8 & 2,7 & $-0,1$ & 1 & -1 \\
2,3 & 2,1 & $-0,2$ & 2,5 & $-2,5$ \\
3,4 & 2,9 & $-0,5$ & 6 & -6 \\
2,9 & 2 & $-0,9$ & 9 & -9 \\
\hline
\end{tabular}

Soma dos rankings positivos

Soma dos rankings negativos

$\begin{array}{ll}7 & \mathrm{~T}=7 \\ 48 & \mathrm{n}=10\end{array}$

Como $\mathrm{n}<30$, então o valor crítico de T está na tabela A-8 (TRIOLA, 2010, pg. 762).

De acordo com a Tabela A-8 e com um nível de significância de 5\%, o "Valor Crítico" é 8.

Como nosso $\mathrm{T}=7$ é menor que o valor crítico 8 , então podemos rejeitar a hipótese nula.

Logo, há diferenças significativas entre a média dos escores do pós-teste imediato e do pós-teste postergado do grupo experimental

Hipóteses:

Ho = Não há diferenças significativas entre a média dos escores do pós-teste imediato e do pós-teste postergado do grupo experimental.

$\mathrm{Hi}=$ Há diferenças significativas entre a média dos escores do pós-teste imediato e do pós-teste postergado do grupo experimental. 


\section{ANEXO M - Teste de Wilcoxon Pareado}

Há diferença significativa entre a média dos escores do pós-teste imediato e dos pósteste postergado do grupo controle?

\begin{tabular}{lll}
\hline Participante & PTI & PTP \\
\hline P1 & 1,8 & 2,1 \\
P2 & 3,6 & 4,3 \\
P3 & 2,3 & 2,5 \\
P4 & 2,0 & 1,9 \\
P5 & 1,7 & 1,7 \\
P6 & 1,9 & 2,2 \\
P7 & 1,8 & 1,5 \\
P8 & 2,4 & 2,8 \\
P9 & 1,8 & 2 \\
P10 & 2,3 & 2,1 \\
P11 & 1,7 & 1,6 \\
\hline
\end{tabular}

\begin{tabular}{lllll}
\hline PTI & PTP & "diferença" d & Ranking de $|\mathbf{d}|$ & Ranking com sinal \\
\hline 1,8 & 2,1 & 0,3 & 7 & 7 \\
3,6 & 4,3 & 0,7 & 10 & 10 \\
2,3 & 2,5 & 0,2 & 4 & 4 \\
2,0 & 1,9 & $-0,1$ & 1,5 & $-1,5$ \\
1,7 & 1,7 & 0 & & \\
1,9 & 2,2 & 0,3 & 7 & 7 \\
1,8 & 1,5 & $-0,3$ & 7 & -7 \\
2,4 & 2,8 & 0,4 & 9 & 9 \\
1,8 & 2 & 0,2 & 4 & 4 \\
2,3 & 2,1 & $-0,2$ & 4 & -4 \\
1,7 & 1,6 & $-0,1$ & 1,5 & $-1,5$
\end{tabular}

Soma dos positivos

Soma negativos

Como $\mathrm{n}<30$, então o valor crítico de T está na tabela A-8 (TRIOLA, 2010, p. 762).

De acordo com a Tabela A-8 e com um nível de significância de 5\%, o "Valor Crítico" é 8.

Como nosso $\mathrm{T}=14$ é maior que o valor crítico 8 , não podemos rejeitar a hipótese nula.

Logo, não há diferença significativa entre a média dos escores do pós-teste imediato e dos pós-teste postergado do grupo controle.

Hipóteses:

Ho = Não há diferenças significativas entre a média dos escores do pós-teste imediato e do pós-teste postergado do grupo controle.

Hi = Há diferenças significativas entre a média dos escores do pós-teste imediato e do pós-teste postergado do grupo controle. 


\section{ANEXO N - Coeficiente de Correlação de Spearman}

Análise de correlação entre as variáveis médias dos escores do PTI e média das intervenções.

\begin{tabular}{|c|c|c|c|c|c|}
\hline $\begin{array}{c}\text { X - Média } \\
\text { intervenções }\end{array}$ & $\begin{array}{l}\text { Média } \\
\text { PTI }\end{array}$ & $\begin{array}{c}\text { Rank - } \\
\text { Média } \\
\text { intervenções }\end{array}$ & $\begin{array}{c}\text { Rank - } \\
\text { Média } \\
\text { PTI }\end{array}$ & $\begin{array}{l}\text { Dif. } \\
\text { entre } \\
\text { rankings }\end{array}$ & $\begin{array}{l}\text { "d" } \\
\text { os d^2 }\end{array}$ \\
\hline 8,27 & 2,3 & 7 & 1 & -6 & 36 \\
\hline 8,24 & 3,1 & 6 & 5 & -1 & 1 \\
\hline 8,27 & 4,1 & 7 & 9 & 2 & 4 \\
\hline 8,49 & 4,4 & 8 & 11 & 3 & 9 \\
\hline 9,00 & 3,5 & 10 & 8 & -2 & 4 \\
\hline $\mathbf{7 , 5 1}$ & 3,2 & 5 & 6 & 1 & 1 \\
\hline 9,02 & 2,6 & 11 & 2 & -9 & 81 \\
\hline 8,59 & 4,2 & 9 & 10 & 1 & 1 \\
\hline 7,47 & 2,8 & 4 & 3 & -1 & 1 \\
\hline 5,70 & 2,3 & 2 & 1 & -1 & 1 \\
\hline 4,05 & 3,4 & 1 & 7 & 6 & 36 \\
\hline 7,16 & 2,9 & 3 & 4 & 1 & 1 \\
\hline \multicolumn{2}{|l|}{ Soma d^2 } & & \multirow{2}{*}{\multicolumn{2}{|c|}{0,3846154}} & \\
\hline 12 & & parâmetro rs & & & \\
\hline
\end{tabular}

Como $\mathrm{n}<=30$, os valores críticos de rs são achados na tabela A-9 (TRIOLA, 2010, p. 763).

Valor crítico rs $= \pm 0,587$

Como rs < rs crítico, nossa correlação está dentro do intervalo de valores críticos $( \pm 0,587)$, então não podemos descartar a hipótese nula. Isso significa que não há correlação entre esses dados, ou seja, a variável "média das intervenções" não influencia na variável "média dos escores PTI". 


\section{ANEXO O - Coeficiente de Correlação de Spearman}

Análise de correlação entre as variáveis médias dos escores do PTP e média das intervenções.

\begin{tabular}{|c|c|c|c|c|c|}
\hline $\begin{array}{c}\text { X - Média } \\
\text { intervenções }\end{array}$ & $\begin{array}{c}\text { Média } \\
\text { PTP }\end{array}$ & $\begin{array}{c}\text { Rank - } \\
\text { Média } \\
\text { intervenções }\end{array}$ & $\begin{array}{c}\text { Rank - } \\
\text { Média } \\
\text { PTP }\end{array}$ & $\begin{array}{l}\text { Dif. } \\
\text { entre } \\
\text { rankings }\end{array}$ & $\begin{array}{l}d^{\prime \prime} \\
\text { os } d^{\wedge} \mathbf{2}\end{array}$ \\
\hline 8,27 & 2,0 & 7 & 1 & -6 & 6 \\
\hline 8,24 & 2,0 & 6 & 1 & -5 & 5 \\
\hline 8,27 & 2,1 & 7 & 2 & -5 & 25 \\
\hline 8,49 & 2,5 & 8 & 3 & -5 & 25 \\
\hline 9,00 & 2,6 & 10 & 4 & -6 & 36 \\
\hline 7,51 & 2,7 & 5 & 5 & 0 & 0 \\
\hline 9,02 & 2,9 & 11 & 6 & -5 & 25 \\
\hline 8,59 & 3,1 & 9 & 7 & -2 & 4 \\
\hline 7,47 & 3,1 & 4 & 7 & 3 & 9 \\
\hline 5,70 & 3,5 & 2 & 8 & 6 & 36 \\
\hline 4,05 & 3,7 & 1 & 9 & 8 & 64 \\
\hline 7,16 & 4,7 & 3 & 10 & 7 & 49 \\
\hline
\end{tabular}

Soma d^2

334

n 12

parâmetro rs $\quad-\mathbf{0 , 1 6 7 8}$

Como $\mathrm{n}<=30$, os valores críticos de rs são achados na tabela A-9 (TRIOLA, 2010, p.763).

Valor crítico rs $= \pm 0,587$.

Como rs < rs crítico, nossa correlação está dentro do intervalo de valores críticos $( \pm 0,587)$, então não podemos descartar a hipótese nula. Isso significa que não há correlação entre esses dados, ou seja, a variável "média das intervenções" não influencia na variável "média dos escores do PTP". 


\section{ANEXO P - Coeficiente de Correlação de Spearman}

Análise de correlação entre as variáveis diferença entre as médias dos escores do PTI e PTP e média das intervenções.

\begin{tabular}{|c|c|c|c|c|c|}
\hline $\begin{array}{c}\text { X - Média } \\
\text { intervenções }\end{array}$ & $\begin{array}{l}\text { Média } \\
\text { PTP }\end{array}$ & $\begin{array}{c}\text { Rank - } \\
\text { Média } \\
\text { intervenções }\end{array}$ & $\begin{array}{c}\text { Rank - } \\
\text { Média } \\
\text { PTP }\end{array}$ & $\begin{array}{l}\text { Dif. } " \mathrm{c} \\
\text { entre } \mathrm{c} \\
\text { rankings }\end{array}$ & $\begin{array}{l}d^{\prime \prime} \\
\text { os } \mathbf{d}^{\wedge} \mathbf{2}\end{array}$ \\
\hline 8,27 & 0,3 & 7 & 1 & -6 & 36 \\
\hline 8,24 & 0 & 6 & 2 & -4 & 16 \\
\hline 8,27 & $-0,6$ & 7 & 3 & -4 & 16 \\
\hline 8,49 & 0,3 & 8 & 4 & -4 & 16 \\
\hline 9,00 & 0,2 & 10 & 5 & -5 & 25 \\
\hline 7,51 & $-0,7$ & 5 & 6 & 1 & 1 \\
\hline 9,02 & 0 & 11 & 7 & -4 & 16 \\
\hline 8,59 & $-1,1$ & 9 & 8 & -1 & 1 \\
\hline 7,47 & $-0,1$ & 4 & 9 & 5 & 25 \\
\hline 5,70 & $-0,2$ & 2 & 9 & 7 & 49 \\
\hline 4,05 & $-0,5$ & 1 & 10 & 9 & 81 \\
\hline 7,16 & -0.9 & 3 & 11 & 8 & 64 \\
\hline
\end{tabular}

Soma d^2

n 12

\section{6}

parâmetro rs $\quad-\mathbf{0 , 2 0 9 8}$

Como $\mathrm{n}<=30$, os valores críticos de rs são achados na tabela A-9 (TRIOLA, 2010, p.763).

Valor crítico rs $= \pm 0,587$.

Como rs < rs crítico, nossa correlação está dentro do intervalo de valores críticos $( \pm 0,587)$, então não podemos descartar a hipótese nula. Isso significa que não há correlação entre esses dados, ou seja, a variável "média das intervenções" não influencia na variável "diferença entre as médias dos escores do PTP e PTI ". 


\section{APÊNDICE A - Termo de autorização institucional}

\section{TERMO DE AUTORIZAÇÃO INSTITUCIONAL}

São Bernardo do Campo, 01 de Agosto de 2014.

Ilustríssimo

Eu, Monica Jessica Aparecida Fernandes Yamamoto, responsável principal pela pesquisa de mestrado intitulada "A Abordagem Lexical no Ensino de Vocabulário em Língua Japonesa", sob orientação da Prof. Doutora Junko Ota, venho pelo presente solicitar vossa autorização para desenvolver este projeto de pesquisa na Escola X durante as aulas de língua japonesa dos sextos anos A/B do EFII.

Este projeto de pesquisa tem como objetivo avaliar a validade da Abordagem Lexical no ensino de língua japonesa, em especial no que se refere ao desenvolvimento da competência lexical, por meio da análise de dados obtidos de testes de vocabulários aplicados após a elaboração e execução de aulas especialmente delineadas para essa ocasião. Acreditase que esta pesquisa é importante, porque se trata de uma busca por caminhos que facilitem e promovam a aprendizagem desse idioma de maneira eficiente. Esta atividade não apresenta riscos aos sujeitos participantes e não haverá nenhuma alteração na rotina escolar, nem no conteúdo programático previsto para o ano letivo. O período previsto para coleta de dados é de agosto a dezembro de 2014.

Espera-se com esta pesquisa encontrar caminhos para a otimização das aulas e o aprimoramento das estratégias de ensino-aprendizagem de vocabulário em língua japonesa, tornando essa tarefa mais fácil para os alunos.

Qualquer informação adicional poderá ser obtida diretamente com a pesquisadora responsável pela pesquisa.

A qualquer momento, vossa senhoria poderá solicitar esclarecimento sobre o desenvolvimento do projeto de pesquisa que está sendo realizado e, sem qualquer tipo de cobrança, poderá retirar sua autorização.

Os dados obtidos nesta pesquisa poderão ser utilizados na publicação de artigos científicos, mas assumimos a total responsabilidade de não publicar, em hipótese alguma, qualquer dado que comprometa o sigilo da participação dos integrantes de vossa instituição como nome, endereço e outras informações pessoais. Na eventualidade de a participação nesta 
pesquisa causar qualquer tipo de dano aos participantes, comprometemo-nos a reparar esse dano, e/ou ainda prover meios para a reparação. A participação será voluntária, não fornecemos por ela qualquer tipo de pagamento.

\section{Autorização Institucional}

$\mathrm{Eu}$, , responsável pela instituição , declaro que fui informado dos objetivos da

pesquisa acima e concordo em autorizar a execução da mesma nesta instituição. Caso necessário, a qualquer momento, como instituição CO-PARTICIPANTE desta pesquisa, poderemos revogar esta autorização, se comprovadas atividades que causem algum prejuízo à esta instituição, ou ainda, a divulgação de qualquer dado que comprometa o sigilo da participação dos integrantes desta instituição. Declaro também que não recebemos qualquer pagamento por esta autorização, bem como os participantes também não receberão qualquer tipo de pagamento.

Responsável pela instituição

Pesquisador

Orientador

\section{DADOS DA PESQUISADORA}

Nome: Monica Jessica Aparecida Fernandes Yamamoto

Endereço: Av. Caminho do mar, 2427 - Rudge Ramos / SBC

E-mail: monicaajf@yahoo.com.br

TEL: (11) 98661-3900 


\section{APÊNDICE B - Termo de Consentimento Livre e Esclarecido}

\section{Termo de Consentimento Livre e Esclarecido (TCLE)}

$\mathrm{Eu}$, Monica Jessica Aparecida Fernandes Yamamoto, responsável pela pesquisa “A Abordagem Lexical no Ensino de Vocabulário em Língua Japonesa”, sob orientação da Prof. Doutora Junko Ota, convido a seu (sua) filho (filha) para participar deste estudo.

Esta pesquisa pretende avaliar a validade da Abordagem Lexical no ensino de língua japonesa, em especial no que se refere ao desenvolvimento da competência lexical, por meio da análise de dados obtidos de testes de vocabulários aplicados após a elaboração e execução de aulas especialmente delineadas para essa ocasião. Acredita-se que esta pesquisa é importante, porque trata-se de uma busca por caminhos que facilitem e promovam a aprendizagem desse idioma de maneira eficiente.

Para sua realização faz-se necessário as seguintes etapas:

- Pesquisa bibliográfica sobre abordagens e metodologias de ensino de línguas estrangeiras (etapa concluída);

- Pesquisa bibliográfica sobre a Abordagem Lexical (etapa concluída);

- Realização de aulas elaboradas para testagem da Abordagem Lexical;

- Realização de testes de vocabulário;

- Análise dos dados.

A participação de seu (sua) filho (filha) será durante as aulas e nos testes de vocabulário, os quais proporcionarão os dados principais para a análise deste estudo. Não haverá nenhuma alteração na rotina escolar e nem no conteúdo programático previsto para o ano. Os benefícios que se espera do estudo é a otimização das aulas e o aprimoramento das estratégias de ensino- aprendizagem de vocabulário em língua japonesa, tornando essa tarefa mais fácil para os alunos.

Durante todo o período da pesquisa os senhores têm o direito de solicitar qualquer esclarecimento, bastando para isso entrar em contato com a pesquisadora responsável.

Os senhores também têm garantido o direito de não aceitar participar ou de retirar a permissão, a qualquer momento, sem nenhum tipo de prejuízo ou retaliação pela sua decisão.

As informações desta pesquisa serão confidenciais com divulgação restrita a eventos ou publicações científicas, mas sem a identificação dos voluntários, sendo assegurado o sigilo de seu (sua) filho (filha). 


\section{Autorização}

$\mathrm{Eu}$, , responsável por após a leitura deste documento e esclarecido todas as minhas dúvidas, acredito estar suficientemente informado, ficando claro para mim que a participação de meu (minha) filho (filha) é voluntária e que posso retirar este consentimento a qualquer momento sem penalidades ou perda de qualquer benefício. Estou ciente também dos objetivos da pesquisa, dos procedimentos aos quais meu (minha) filho (filha) será submetido, da garantia de confidencialidade e esclarecimentos sempre que desejar. Diante do exposto, expresso minha concordância de espontânea vontade em permitir a participação de meu (minha) filho (filha) neste estudo.

de de 2014.

Assinatura do responsável

Declaro que obtive de forma apropriada e voluntária o Consentimento Livre e Esclarecido do responsável deste (a) voluntário (a) para a participação neste estudo.

Monica J. A. F. Yamamoto

\section{DADOS DA PESQUISADORA}

Nome: Monica Jessica Aparecida Fernandes Yamamoto

Endereço: Av. Caminho do mar, 2427 - Rudge Ramos / SBC

E-mail: monicaajf@yahoo.com.br

TEL: (11) 98661-3900 


\section{APÊNDICE C - Planos de Aula \\ Sequência didática - Tópico 7 - 12 aulas}

Ano: $6^{\circ} \mathrm{A}(\mathrm{GE})$

Data: $24 / 10$ a 07/11/2014

No Alunos: 22

Material: Marugoto Katsudô / Rikai - Tópico 7 - L13/14 Tópico: 「まち」

Objetivos:

- Conseguir ler placas nas estações de trem e pontos de táxis;

- Conseguir utilizar táxi e informar o destino desejado;

- Conseguir conversar sobre qual é o melhor meio de transporte para ir aos locais desejados;

- Conseguir justificar a escolha do meio de transporte;

- Conseguir conversar sobre a duração do deslocamento de determinado trecho;

- Conseguir conversar sobre o local onde quer ir usando um mapa;

- Conseguir entender orientações de deslocamento;

- Conseguir informar o local onde está por telefone;

- Conseguir ler as informações sobre horário de funcionamento de estabelecimentos.

Conteúdos:

\section{$\rightarrow$ Linguístico}

・うちから えきまで バスで いきます。

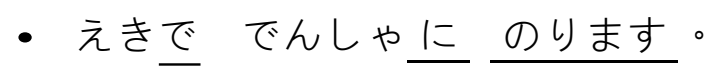

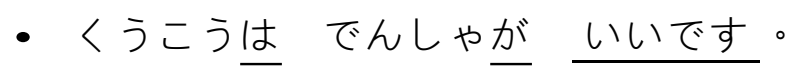

・はやいですから。

・ふるいじんじゃ、にぎやかなまち。

・さいたまにふるいじんじゃが市ります。

・さいたまには よ゙うぶつえんは ありません。

・えき元なり、きっさてんの立え。

・きさってんはええきのとなりに市ります。

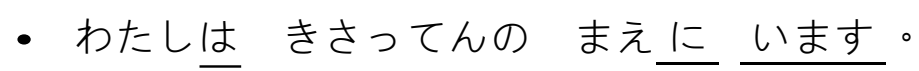




\section{$\rightarrow$ Itens lexicais novos}

\} Introduzir a noção de chunks visando estimular a percepção de como as palavras se relacionam.

\section{Palavras:}

まち・バイク・じてんしゃ・ちかてつ・タクシー・でんしゃ・くうしゃ・つきまし た・おきゃくさん・らく・ベんり・ふべん・ゆうめい·まち・どうやって・サイ ン・にもつ・ホテル・グリンパーク・とうきょう・タワー・せんそうじ・うえの・ あさくさ・えき・くうこう・ぎんこう・おてら・じんじゃ・にぎやかな・とおり・ ビル・ちず・みぎ・ひだり・そして・えいぎょうじかん・ていきゅうび・へいじ つ・しゅくじつ・ねんじゅうむきゅう・コンビニ・じどうはんばいき・マンホー ル・こうばん・ちゅうりんじょう・ポスト・とおい・ちかい・うんてんしゅう・ひ こうき・バス・のりば・ふべん・つかれます・ひがし・にし・みなに・きた・きさ ってん・ひくい・しずかな

Colocações:

•__にのります。

•__をおります。

・__ でのります/おりす。

•__でいきます。
・あるいていきます。

・とうきょうタワー。

・バスのりば。

\section{Expressões:}

・—_ までどうやっていきますか。

・すみません、おねがいします。

・どちらまでですか。

・__ _ _ までおねがいします。

・カードでいいですか。

・ いくらですか。

・ ここでいいです。
・きをつけて。

- _ _ _ がいいですよ。

・もういちどいってください。

・ ここにかいてください。

・まっすぐいってください。

・もしもしいま どこですか。

・どこにいますか。 


\section{$\rightarrow$ Cultural}

- Explorar a questão da mobilidade urbana traçando uma discussão sobre as semelhanças e diferenças entre o sistema de transporte do Japão e do Brasil. Identificar os pontos positivos e negativos sobre o assunto em ambos os países e o impacto desses na vida cotidiana;

- Explorar a diferença entre a percepção de distância decorrente da diferença de tamanho entre os países;

- Explorar as características organizacionais e do comércio das cidades japonesas, tais como serviços públicos (correios e postos policiais), lojas de conveniência, máquinas de venda automática e o uso de bicicletas.

\begin{tabular}{|c|c|c|c|}
\hline \multicolumn{4}{|c|}{ Desenvolvimento - Aula 1 (Katsudô - L13) } \\
\hline Tempo & Atividade & Procedimento & Observações \\
\hline $2 \mathrm{~min}$ & Início da aula. & Realizar o kiritsu com o aluno $\mathrm{n}^{\circ} 1$ da lista. & \\
\hline $15 \mathrm{~min}$ & $\begin{array}{l}\text { Explicação sobre a } \\
\text { pesquisa e entrega do } \\
\text { TCLE. }\end{array}$ & $\begin{array}{l}\text { - Explicar sobre a pesquisa; } \\
\text { - Entregar o TCLE; }\end{array}$ & \\
\hline $5 \mathrm{~min}$ & $\begin{array}{l}\text { Introdução da lição } \\
\text { (p.83). }\end{array}$ & $\begin{array}{l}\text { - Mostrar a foto de introdução da lição e } \\
\text { iniciar um diálogo sobre os possíveis } \\
\text { objetivos da aula. Perguntas diretivas: } \\
\text { 1) Pessoal, olhem a foto, sobre o que vocês } \\
\text { acham que nós vamos falar? } \\
\text { 2) E qual é a cidade da foto? (Explicar que } \\
\text { se trata de uma foto do cruzamento de } \\
\text { Shibuya - Tóquio). } \\
\text { 3) E o que vocês acham que nós vamos } \\
\text { aprender sobre a língua japonesa? } \\
\text { 4) O que nós conseguiremos fazer depois de } \\
\text { estudarmos esse tema? } \\
\text { - Ler os objetivos com os alunos. }\end{array}$ & \\
\hline $7 \mathrm{~min}$ & $\begin{array}{l}\text { Seção } 1 \text { - Explorar } \\
\text { itens lexicais (p.84). }\end{array}$ & $\begin{array}{l}\text { - Apresentar os itens da página e indicar que } \\
\text { se tratam de meios de transporte; } \\
\text { - Passar o áudio (compreensão global); } \\
\text { - Passar o áudio (ouvir e repetir); } \\
\text { - Passar o áudio (ouvir, repetir e apontar } \\
\text { com o dedo); } \\
\text { - Questionar qual a parte do que foi ouvido } \\
\text { que apareceu em todos os exemplos, } \\
\text { levando-os a perceberem a relação entre a } \\
\text { palavra 「のります」 com os meios de } \\
\text { transportes; } \\
\text { - Sumarizar os itens na lousa com a palavra } \\
\text { 「のります」 ao meio e as suas possíveis } \\
\text { combinações. }\end{array}$ & \\
\hline $5 \mathrm{~min}$ & $\begin{array}{l}\text { Discussão de tópicos } \\
\text { culturais. }\end{array}$ & $\begin{array}{l}\text { Falar sobre o transporte no Japão } \\
\text { pontuando: } \\
\text { - Os tipos de transportes públicos } \\
\text { disponíveis; } \\
\text { - A questão da quantidade de trens; }\end{array}$ & \\
\hline
\end{tabular}




\begin{tabular}{|c|c|c|}
\hline & & $\begin{array}{l}\text { - A configuração das estações; } \\
\text { - A predileção pelo transporte } \\
\text { público; } \\
\text { - O apreço por bicicleta; } \\
\text { - As principais empresas de } \\
\text { transporte; } \\
\text { - O valor do transporte e forma de } \\
\text { cobrança no Japão. } \\
\end{array}$ \\
\hline $3 \min$ & $\begin{array}{l}\text { Apresentar as placas } \\
\text { presentes nas estações. }\end{array}$ & $\begin{array}{l}\text { Perguntar aos alunos qual é a mensagem } \\
\text { contida nas placas. Pontuar que o kanji } \\
\text { 「ロ」 indica saída. }\end{array}$ \\
\hline $3 \min$ & $\begin{array}{l}\text { Levantamento de } \\
\text { expressões necessárias } \\
\text { para se pegar um táxi } \\
\text { (p.85). }\end{array}$ & $\begin{array}{l}\text { Perguntar aos alunos o que nós precisamos } \\
\text { saber falar para pegar um táxi. Anotar as } \\
\text { sugestões na lousa. }\end{array}$ \\
\hline $4 \min$ & $\begin{array}{l}\text { Identificação das } \\
\text { expressões no diálogo } \\
\text { modelo. }\end{array}$ & $\begin{array}{l}\text { - Passar o áudio; } \\
\text { - Perguntar aos alunos em que parte do } \\
\text { diálogo apareceu cada uma das expressões } \\
\text { citadas por eles e como foram ditas. Se } \\
\text { necessário, passar novamente. }\end{array}$ \\
\hline $3 \min$ & Diálogo & $\begin{array}{l}\text { Os alunos, em duplas, farão o diálogo } \\
\text { modelo alterando alguns pontos com } \\
\text { informaçôes chaves escolhidas por eles. }\end{array}$ \\
\hline $2 \mathrm{~min}$ & Perguntas & Espaço para perguntas. \\
\hline
\end{tabular}

\begin{tabular}{|c|c|c|c|}
\hline \multicolumn{4}{|c|}{ Desenvolvimento - Aula 2 (Katsudô - L13) } \\
\hline Tempo & Atividade & Procedimento & Observações \\
\hline $2 \mathrm{~min}$ & Início da aula. & Realizar o kiritsu com o aluno $\mathrm{n}^{\circ} 2$ da lista. & \\
\hline $2 \min$ & Retomada da seção 1. & $\begin{array}{l}\begin{array}{l}\text { Rever o conteúdo trabalhado na aula } \\
\text { anterior. }\end{array} \\
\end{array}$ & \\
\hline $6 \min$ & $\begin{array}{l}\text { Seção } 2 \text { - Exercício de } \\
\text { compreensão auditiva } \\
\text { (p.86). }\end{array}$ & $\begin{array}{l}\text { Apresentar e explicar o que está sendo } \\
\text { pedido no exercício de compreensão } \\
\text { auditiva; } \\
\text { - Passar o áudio (compreensão global); } \\
\text { - Passar o áudio (responder/confirmar). }\end{array}$ & \\
\hline $2 \min$ & Correção em pares. & $\begin{array}{l}\text {-Comparar e discutir as respostas com o } \\
\text { colega; } \\
\text { - Passar o áudio para correção final. }\end{array}$ & \\
\hline $3 \min$ & $\begin{array}{l}\text { Identificação das } \\
\text { expressões no diálogo. }\end{array}$ & $\begin{array}{l}\text { Perguntar quais foram as frases ou } \\
\text { expressões que se repetiram e quando as } \\
\text { usamos. }\end{array}$ & \\
\hline $3 \min$ & Diálogo & $\begin{array}{l}\text { Os alunos, em duplas, farão o diálogo } \\
\text { modelo alterando alguns pontos com } \\
\text { informaçôes chaves escolhidas por eles. }\end{array}$ & \\
\hline $2 \mathrm{~min}$ & $\begin{array}{l}\text { Seção } 3 \text { - Introdução e } \\
\text { explicação } \\
\text { exercício (p.87). }\end{array}$ & $\begin{array}{l}\text { Apresentar e explicar o que está sendo } \\
\text { pedido no exercício de compreensão } \\
\text { auditiva. }\end{array}$ & \\
\hline $4 \min$ & $\begin{array}{l}\text { Exercício de } \\
\text { compreensão auditiva. }\end{array}$ & $\begin{array}{l}\text { - Passar o áudio (compreensão global); } \\
\text { - Passar o áudio (responder/confirmar). }\end{array}$ & \\
\hline $2 \min$ & Correção em pares. & $\begin{array}{l}\text {-Comparar e discutir as respostas com o } \\
\text { colega; } \\
\text { - Passar o áudio para correção final. }\end{array}$ & \\
\hline $3 \min$ & $\begin{array}{l}\text { Identificação } \quad \text { das } \\
\text { expressões no diálogo. }\end{array}$ & $\begin{array}{ll}\text { Perguntar quais foram as frases ou } \\
\text { expressões }\end{array}$ & \\
\hline
\end{tabular}




\begin{tabular}{|c|c|c|c|}
\hline & & usamos. & \\
\hline $3 \min$ & Diálogo & $\begin{array}{l}\text { Os alunos, em duplas, farão o diálogo } \\
\text { modelo alterando alguns pontos com } \\
\text { informações chaves escolhidas por eles. }\end{array}$ & \\
\hline $14 \mathrm{~min}$ & $\begin{array}{l}\text { Introdução sobre a } \\
\text { noção de chunks. }\end{array}$ & $\begin{array}{l}\text { Dialogar com os alunos sobre como a língua } \\
\text { é produzida e organizada. Prover exemplos } \\
\text { de como organizamos tudo em pedaços e } \\
\text { não em palavras. Exemplos: "tomando } \\
\text { sorvete", "chupando sorvete" "olhando } \\
\text { pela janela", "basu ni norimasu" e } \\
\text { "aisukurîmu o tabemasu". }\end{array}$ & $\begin{array}{l}\text { Usar as } \\
\text { imagens. } \\
\text { Ofercer } \\
\text { exemplos das } \\
\text { línguas } \\
\text { portuguesa e } \\
\text { japonesa: }\end{array}$ \\
\hline $2 \mathrm{~min}$ & Perguntas & Espaço para perguntas. & \\
\hline $2 \min$ & \multicolumn{3}{|c|}{ Encerrar a aula com o kiritsu. } \\
\hline
\end{tabular}

\begin{tabular}{|c|c|c|c|}
\hline \multicolumn{4}{|c|}{ Desenvolvimento - Aula 3 (Rikai - L13) } \\
\hline Tempo & Atividade & Procedimento & Observações \\
\hline $2 \mathrm{~min}$ & Início da aula. & Realizar o kiritsu com o aluno $\mathrm{n}^{\circ} 3$ da lista. & \\
\hline $12 \min$ & $\begin{array}{l}\text { Seção } 1-\text { Exercícios } \\
\text { de } \\
\text { (p.118). }\end{array}$ & $\begin{array}{l}\text { - Apresentar e explicar o que está sendo } \\
\text { pedido nos exercícios de vocabulário } 1,2 \text { e } \\
3 \text {; } \\
\text { - Fazer os exercícios } 1,2 \text { e } 3 \text {. }\end{array}$ & \\
\hline $3 \mathrm{~min}$ & Correção em pares. & $\begin{array}{l}\text { - Comparar e discutir as respostas com o } \\
\text { colega; } \\
\text { - Passar o áudio para correção final. }\end{array}$ & \\
\hline $3 \min$ & $\begin{array}{l}\text { Exercício de escrita } \\
\text { (p.119). }\end{array}$ & $\begin{array}{l}\text { - Escrever as palavras ouvidas usando os } \\
\text { sistemas de escrita da LJ. }\end{array}$ & \\
\hline $3 \min$ & Correção em pares. & $\begin{array}{l}\text {-Comparar e discutir as respostas com o } \\
\text { colega; } \\
\text { - Passar a correção na lousa. }\end{array}$ & \\
\hline $4 \mathrm{~min}$ & Kanji & $\begin{array}{l}\text { Apresentação das leituras dos kanji 東· } \\
\text { 西·南・北・ロ. }\end{array}$ & \\
\hline $10 \mathrm{~min}$ & $\begin{array}{lr}\text { Continuação } & \text { da } \\
\text { explicação sobre } & \text { a } \\
\text { noção de chunks. }\end{array}$ & $\begin{array}{l}\text { Apresentar os tipos de itens lexicais: } \\
\text { palavras, polipalavras, colocações es } \\
\text { expressões fixas e semifixas. }\end{array}$ & $\begin{array}{l}\text { Oferecer } \\
\text { exemplos das } \\
\text { línguas } \\
\text { portuguesa e } \\
\text { japonesa. }\end{array}$ \\
\hline $8 \min$ & $\begin{array}{l}\text { Atividade: percebendo } \\
\text { os chunks do diálogo. }\end{array}$ & $\begin{array}{l}\text { Solicitar aos alunos encontrem nas lições } \\
\text { anteriores dos livros os itens lexicais } \\
\text { apresentados. Comparar com o colega. }\end{array}$ & $\begin{array}{l}\text { Perceber } \mathrm{a} \\
\text { formação de } \\
\text { chunks. }\end{array}$ \\
\hline $3 \mathrm{~min}$ & Perguntas & Espaço para perguntas. & \\
\hline $2 \mathrm{~min}$ & & Encerrar a aula com o kiritsu. & \\
\hline
\end{tabular}

\begin{tabular}{|c|c|c|c|}
\hline \multicolumn{4}{|c|}{ Desenvolvimento - Aula 4 (Rikai - L13) } \\
\hline Tempo & Atividade & Procedimento & Observações \\
\hline $2 \mathrm{~min}$ & Início da aula. & Realizar o kiritsu com o aluno $\mathrm{n}^{\circ} 4$ da lista. & \\
\hline $2 \min$ & Retomada da seção 1. & $\begin{array}{l}\text { Rever o conteúdo trabalhado na aula } \\
\text { anterior. }\end{array}$ & \\
\hline $2 \min$ & $\begin{array}{l}\text { Seção } 2-\text { Ouvir o } \\
\text { diálogo } \\
\text { (p.120). }\end{array}$ & Passar o áudio. & \\
\hline $4 \min$ & $\begin{array}{l}\text { Identificação das } \\
\text { expressões no diálogo. }\end{array}$ & $\begin{array}{l}\text { - Perguntar sobre o conteúdo do diálogo; } \\
\text { - Identificar as expressões; } \\
\text { - Passar o áudio novamente. }\end{array}$ & \\
\hline $6 \min$ & Compreensão & - Discutir em grupo (máx. 4 alunos) o & \\
\hline
\end{tabular}




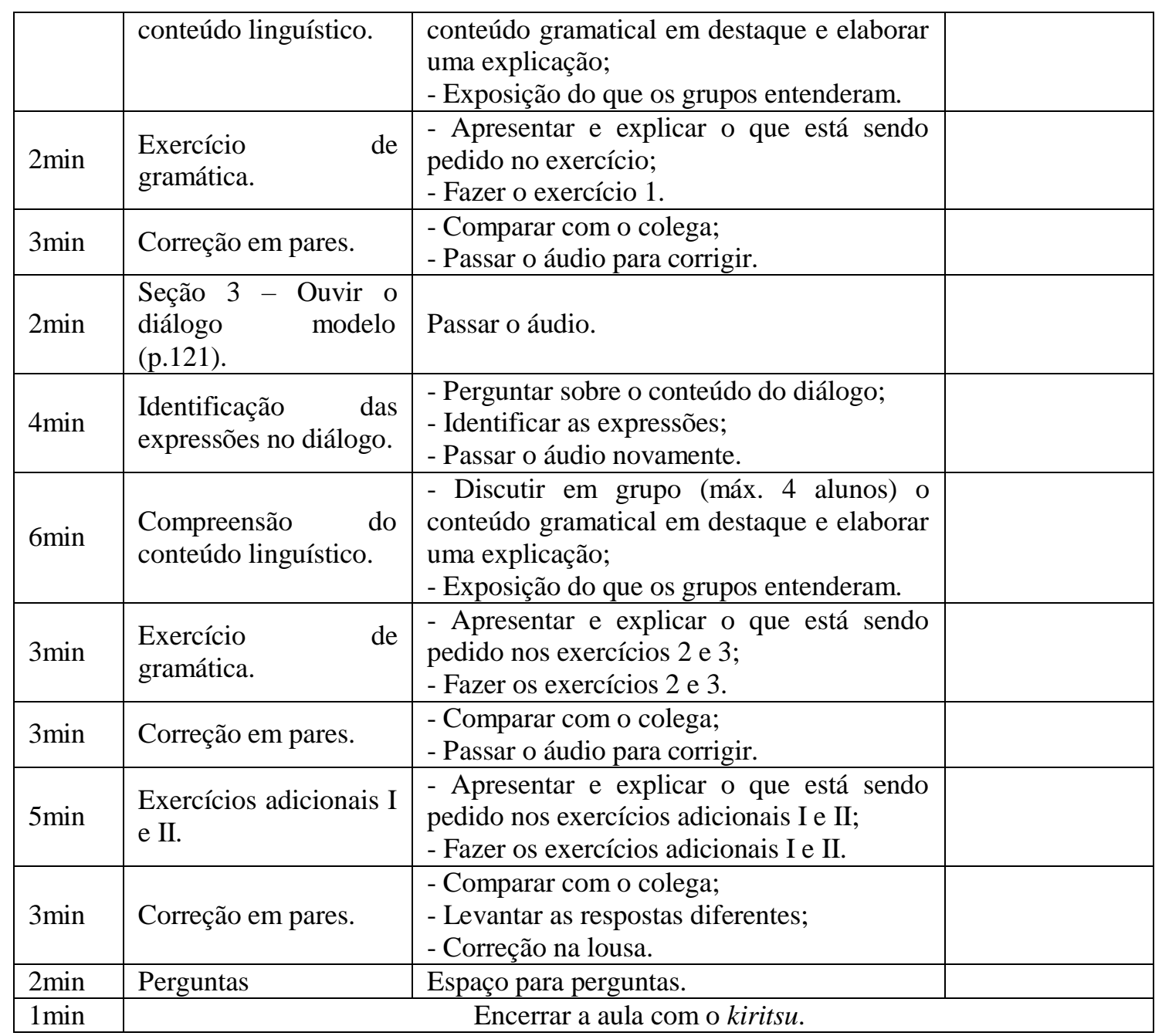

\begin{tabular}{|c|c|c|c|}
\hline \multicolumn{4}{|c|}{ Desenvolvimento - Aula 5 (Rikai - L13) } \\
\hline Tempo & Atividade & Procedimento & Observações \\
\hline $2 \min$ & Início da aula. & Realizar o kiritsu com o aluno $\mathrm{n}^{\circ} 5$ da lista. & \\
\hline $2 \min$ & $\begin{array}{l}\text { Retomada das seções } \\
2 \text { e } 3 .\end{array}$ & $\begin{array}{l}\text { Rever o conteúdo trabalhado na aula } \\
\text { anterior. }\end{array}$ & \\
\hline $2 \min$ & $\begin{array}{l}\text { Seção } 4-\text { Ouvir o } \\
\text { diálogo } \\
\text { (p.122). }\end{array}$ & Passar o áudio. & \\
\hline $5 \mathrm{~min}$ & $\begin{array}{ll}\text { Identificação } & \text { das } \\
\text { expressões no diálogo. }\end{array}$ & $\begin{array}{l}\text { - Perguntar sobre o conteúdo do diálogo; } \\
\text { - Identificar as expressões; } \\
\text { - Passar o áudio novamente. }\end{array}$ & \\
\hline $7 \min$ & $\begin{array}{l}\text { Compreensão do } \\
\text { conteúdo linguístico. }\end{array}$ & $\begin{array}{l}\text { - Discutir em grupo (máx. } 4 \text { alunos) o } \\
\text { conteúdo gramatical em destaque e elaborar } \\
\text { uma explicação; } \\
\text { - Exposição do que os grupos entenderam. }\end{array}$ & \\
\hline $3 \min$ & $\begin{array}{l}\text { Exercício } \\
\text { gramática. }\end{array}$ & $\begin{array}{l}\text { - Apresentar e explicar o que está sendo } \\
\text { pedido no exercício1; } \\
\text { - Fazer o exercício } 1 .\end{array}$ & \\
\hline $3 \min$ & Correção em pares. & $\begin{array}{l}\text { - Comparar com o colega; } \\
\text { - Passar o áudio novamente para corrigir. }\end{array}$ & \\
\hline $2 \min$ & $\begin{array}{l}\text { Seção 5 } \\
\text { diálogo Preencher o } \\
\text { (p.123). }\end{array}$ & Preencher os espaços do diálogo modelo. & \\
\hline $3 \min$ & Correção em pares. & - Comparar com o colega; & \\
\hline
\end{tabular}




\begin{tabular}{|c|c|c|c|}
\hline & & - Passar o áudio para corrigir. & \\
\hline $3 \min$ & Diálogo & $\begin{array}{l}\text { Os alunos, em duplas, farão o diálogo } \\
\text { modelo alterando alguns pontos com } \\
\text { informações chaves escolhidas por eles. }\end{array}$ & \\
\hline $15 \mathrm{~min}$ & Atividade adicional I. & $\begin{array}{l}\text { Fazer a primeira parte da atividade adicional } \\
\text { I “jogo de cartas”; } \\
\text { - Dividir a turma em grupos com } 4 \text { alunos; } \\
\text { - Distribuir as cartas com partes de } \\
\text { expressões e colocações; } \\
\text { - Combinar as cartas da mão com as cartas } \\
\text { da mesa formando as colocações e } \\
\text { expressões; } \\
\text { - Ganha quem conseguir usar todas as cartas } \\
\text { da mão para formar as colocações e } \\
\text { expressões ou quem conseguir formar mais } \\
\text { em um período de dez minutos. }\end{array}$ & $\begin{array}{l}\text { Ao final de } \\
\text { cada partida, } \\
\text { tirar foto das } \\
\text { cartas para } \\
\text { posterior } \\
\text { correção com a } \\
\text { turma. }\end{array}$ \\
\hline $2 \mathrm{~min}$ & Perguntas & Espaço para perguntas. & \\
\hline $1 \min$ & \multicolumn{3}{|c|}{ Encerrar a aula com o kiritsu. } \\
\hline
\end{tabular}

\begin{tabular}{|c|c|c|c|}
\hline \multicolumn{4}{|c|}{ Desenvolvimento - Aula 6 (Rikai - L13) } \\
\hline Tempo & Atividade & Procedimento & Observações \\
\hline $2 \min$ & Início da aula. & Realizar o kiritsu com o aluno $\mathrm{n}^{\circ} 6$ da lista. & \\
\hline $2 \mathrm{~min}$ & $\begin{array}{l}\text { Retomada das seções } \\
4 \text { e } 5 .\end{array}$ & $\begin{array}{l}\text { Rever o conteúdo trabalhado na aula } \\
\text { anterior. }\end{array}$ & \\
\hline $10 \mathrm{~min}$ & $\begin{array}{l}\text { Seção } 6 \text { - Exercício de } \\
\text { compreensão de texto } \\
\text { (p.124). }\end{array}$ & $\begin{array}{l}\text { - Apresentar e explicar o que está sendo } \\
\text { pedido no exercício de compreensão de } \\
\text { leitura; } \\
\text { - Fazer o exercício de compreensão de } \\
\text { texto. }\end{array}$ & \\
\hline $3 \mathrm{~min}$ & Correção em pares. & $\begin{array}{l}\text { - Comparar com o colega; } \\
\text { - Passar o áudio do texto lido; } \\
\text { - Corrigir com a professora. }\end{array}$ & \\
\hline $10 \mathrm{~min}$ & $\begin{array}{l}\text { Seção } 7 \text { - Exercício de } \\
\text { produção } \\
\text { (p.125). }\end{array}$ & $\begin{array}{l}\text { - Apresentar e explicar o que está sendo } \\
\text { pedido no exercício de compreensão de } \\
\text { leitura; } \\
\text { - Fazer um pequeno texto sobre como se } \\
\text { locomove da casa para a escola, tomando } \\
\text { como base um texto exemplo. }\end{array}$ & \\
\hline $5 \mathrm{~min}$ & Correção em pares. & Corrigir as redações em pares. & \\
\hline $15 \mathrm{~min}$ & $\begin{array}{l}\text { Continuação da } \\
\text { atividade adicional I. }\end{array}$ & $\begin{array}{l}\text { - Exibir as fotos tiradas das partidas da aula } \\
\text { anterior, discutir e identificar possíveis } \\
\text { combinações não usuais; } \\
\text { - Organizar os grupos novamente e jogar } \\
\text { mais uma partida. }\end{array}$ & \\
\hline $2 \mathrm{~min}$ & Perguntas & Espaço para perguntas. & \\
\hline $1 \mathrm{~min}$ & & Encerrar a aula & \\
\hline
\end{tabular}

\begin{tabular}{|l|l|l|l|}
\hline \multicolumn{4}{|c|}{ Desenvolvimento - Aula 7 (Katsudô - L14) } \\
\hline Tempo & \multicolumn{1}{|c|}{ Atividade } & \multicolumn{1}{c|}{ Procedimento } & Observações \\
\hline 2min & Início da aula. & Realizar o kiritsu com o aluno n 7 da lista. & \\
\hline 2min & $\begin{array}{l}\text { Retomada do tema do } \\
\text { tópico. }\end{array}$ & $\begin{array}{l}\text { Rever o tema do tópico e o conteúdo } \\
\text { trabalhado na lição anterior. }\end{array}$ & \\
\hline 7min & $\begin{array}{l}\text { Seção 1 - Explorar } \\
\text { itens lexicais (p.88). }\end{array}$ & $\begin{array}{l}\text { - Apresentar os itens da página e indicar que } \\
\text { se tratam de lugares comuns em uma cidade } \\
\text { grande do Japão; }\end{array}$ & \\
\hline
\end{tabular}




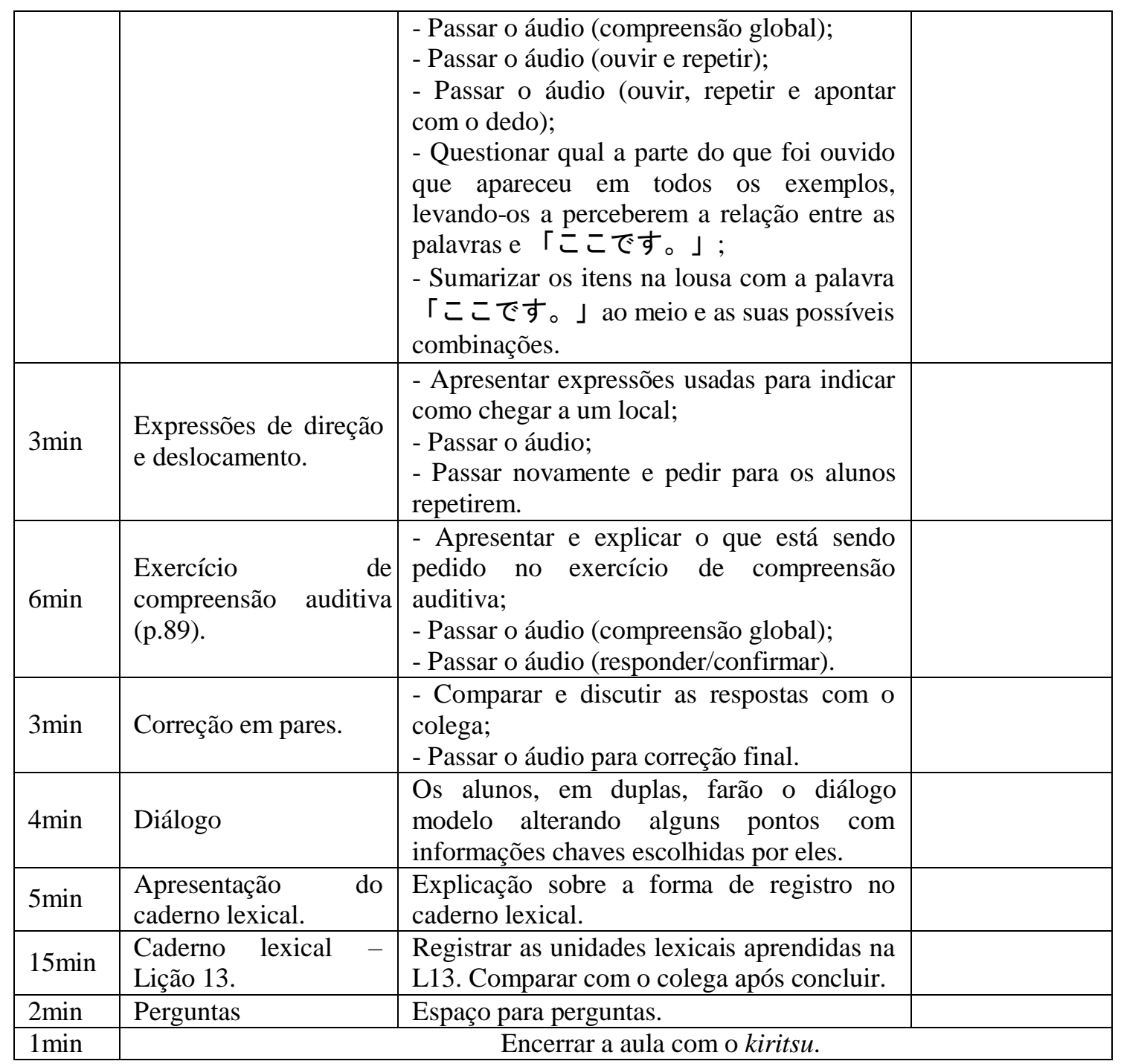

\begin{tabular}{|c|c|c|c|}
\hline \multicolumn{4}{|c|}{ Desenvolvimento - Aula 8 (Katsudô - L14) } \\
\hline Tempo & Atividade & Procedimento & Observações \\
\hline $2 \mathrm{~min}$ & Início da aula. & Realizar o kiritsu com o aluno $\mathrm{n}^{\circ} 8$ da lista. & \\
\hline $2 \min$ & Retomada da seção 1. & $\begin{array}{l}\text { Rever o conteúdo trabalhado na aula } \\
\text { anterior. }\end{array}$ & \\
\hline $10 \min$ & $\begin{array}{l}\text { Seção } 2 \text { - Exercí́cio de } \\
\text { compreensão auditiva } \\
\text { (p.90). }\end{array}$ & $\begin{array}{l}\text { - Apresentar e explicar o que está sendo } \\
\text { pedido no exercício de compreensão } \\
\text { auditiva; } \\
\text { - Revisão de conteúdo visto em lições } \\
\text { anteriores necessário para o exercício } \\
\text { (direções): } \\
\rightarrow \text { Passar o áudio; } \\
\rightarrow \text { Passar novamente e pedir para os alunos } \\
\text { repetirem; } \\
\text { - Fazer o exercício de compreensão } \\
\text { auditiva: } \\
\rightarrow \text { Passar o áudio (compreensão global); } \\
\rightarrow \text { Passar o áudio (responder/confirmar). }\end{array}$ & \\
\hline $3 \min$ & Correção em pares. & $\begin{array}{l}\text { - Comparar e discutir as respostas com o } \\
\text { colega; } \\
\text { - Passar o áudio para correção final. }\end{array}$ & \\
\hline $8 \mathrm{~min}$ & Seção $3-$ Placas & - Explorar os vários formatos de placas & \\
\hline
\end{tabular}




\begin{tabular}{|c|c|c|}
\hline & $\begin{array}{lr}\text { informativas } & \text { de } \\
\text { horário } & \text { de } \\
\text { funcionamento (p.91). }\end{array}$ & $\begin{array}{l}\text { informativas de horário de funcionamento; } \\
\text { - Solicitar aos alunos destacarem as palavras } \\
\text { que consideram mais importantes para se } \\
\text { conseguir obter essa informação. }\end{array}$ \\
\hline $10 \mathrm{~min}$ & Seikatsu to bunka & $\begin{array}{l}\text { - Discussão sobre tipos de loja e serviços } \\
\text { públicos do Japão: } \\
\rightarrow \text { Como e quando funcionam? } \\
\rightarrow \text { Quais os serviços disponíveis? } \\
\rightarrow \text { Quais também existem no Brasil? }\end{array}$ \\
\hline $7 \mathrm{~min}$ & $\begin{array}{l}\text { Exercício adicional } \\
\text { III. }\end{array}$ & $\begin{array}{l}\text { - Apresentar e explicar o que está sendo } \\
\text { pedido no exercício adicional III; } \\
\text { - Fazer o exercício adicional III. }\end{array}$ \\
\hline $5 \mathrm{~min}$ & Correção em pares. & $\begin{array}{l}\text { - Comparar e discutir as respostas com o } \\
\text { colega; } \\
\text { - Corrigir com a professora. }\end{array}$ \\
\hline $2 \mathrm{~min}$ & Perguntas & Espaço para perguntas. \\
\hline $1 \mathrm{~min}$ & & Encerrar a aula com o kiritsu. \\
\hline
\end{tabular}

\begin{tabular}{|c|c|c|c|}
\hline \multicolumn{4}{|c|}{ Desenvolvimento - Aula 9 (Rikai - L14) } \\
\hline Tempo & Atividade & Procedimento & Observações \\
\hline $2 \min$ & Início da aula. & Realizar o kiritsu com o aluno $\mathrm{n}^{\circ} 9$ da lista. & \\
\hline $12 \mathrm{~min}$ & $\begin{array}{l}\text { Seção } 1 \text { - Exercício de } \\
\text { vocabulário (p.126). }\end{array}$ & $\begin{array}{l}\text { - Apresentar e explicar o que está sendo } \\
\text { pedido nos exercícios de vocabulário; } \\
\text { - Fazer os exercícios } 1,2 \text { e } 3 \text {. }\end{array}$ & \\
\hline $4 \min$ & Correção em pares. & $\begin{array}{l}\text { - Comparar e discutir as respostas com o } \\
\text { colega; } \\
\text { - Passar o áudio para correção final. }\end{array}$ & \\
\hline $3 \min$ & $\begin{array}{l}\text { Exercício de escrita } \\
\text { (p.127). }\end{array}$ & $\begin{array}{l}\text { - Escrever as palavras ouvidas usando os } \\
\text { sistemas de escrita da LJ. }\end{array}$ & \\
\hline $4 \min$ & Correção em pares. & $\begin{array}{l}\text {-Comparar e discutir as respostas com o } \\
\text { colega; } \\
\text { - Passar a correção na lousa. }\end{array}$ & \\
\hline $20 \mathrm{~min}$ & Atividade adicional II & $\begin{array}{l}\text { - Apresentar e explicar o que está sendo } \\
\text { pedido na atividade adicional II; } \\
\text { - Fazer a atividade adicional II em dupla. }\end{array}$ & \\
\hline $3 \min$ & Perguntas & Espaço para perguntas. & \\
\hline $2 \min$ & & Encerrar a aula com o kiritsu. & \\
\hline
\end{tabular}

\begin{tabular}{|c|c|c|c|}
\hline \multicolumn{4}{|c|}{ Desenvolvimento - Aula 10 (Rikai - L14) } \\
\hline Tempo & Atividade & Procedimento & Observações \\
\hline $2 \min$ & Início da aula. & $\begin{array}{l}\text { Realizar o Kiritsu com o aluno } \mathrm{n}^{\circ} 10 \mathrm{da} \\
\text { lista. }\end{array}$ & \\
\hline $2 \min$ & Retomada da seção 1. & $\begin{array}{l}\text { Rever o conteúdo trabalhado na aula } \\
\text { anterior. }\end{array}$ & \\
\hline $2 \min$ & $\begin{array}{l}\text { Seção } 2-\text { Ouvir o } \\
\text { diálogo } \\
\text { (p.128). }\end{array}$ & Passar o áudio. & \\
\hline $4 \mathrm{~min}$ & $\begin{array}{l}\text { Identificação das } \\
\text { expressões no diálogo. }\end{array}$ & $\begin{array}{l}\text { - Perguntar sobre o conteúdo do diálogo; } \\
\text { - Identificar as expressões; } \\
\text { - Passar o áudio novamente. }\end{array}$ & \\
\hline $6 \mathrm{~min}$ & $\begin{array}{l}\text { Compreensão do } \\
\text { conteúdo linguístico. }\end{array}$ & $\begin{array}{l}\text { - Discutir em grupo (máx. } 4 \text { alunos) o } \\
\text { conteúdo gramatical em destaque e elaborar } \\
\text { uma explicação; } \\
\text { - Exposição do que os grupos entenderam. }\end{array}$ & \\
\hline $2 \mathrm{~min}$ & Exercício & - Apresentar e explicar o que está sendo & \\
\hline
\end{tabular}




\begin{tabular}{|c|c|c|}
\hline & gramática. & $\begin{array}{l}\text { pedido nos exercícios de gramática } 1 \text { e } 2 \text {; } \\
\text { - Fazer os exercícios de gramática } 1 \text { e } 2 \text {. }\end{array}$ \\
\hline $3 \min$ & Correção em pares. & $\begin{array}{l}\text { - Comparar com o colega; } \\
\text { - Passar o áudio para corrigir. }\end{array}$ \\
\hline $6 \mathrm{~min}$ & $\begin{array}{l}\text { Compreensão do } \\
\text { conteúdo linguístico } \\
(p .129) .\end{array}$ & $\begin{array}{l}\text { - Discutir em grupo (máx. } 4 \text { alunos) o } \\
\text { conteúdo gramatical em destaque e elaborar } \\
\text { uma explicação; } \\
\text { - Exposição do que os grupos entenderam. }\end{array}$ \\
\hline $2 \min$ & $\begin{array}{l}\text { Exercício } \quad \text { de } \\
\text { gramática. }\end{array}$ & $\begin{array}{l}\text { - Apresentar e explicar o que está sendo } \\
\text { pedido nos exercícios de gramática } 1 ; \\
\text { - Fazer os exercícios de gramática } 1 .\end{array}$ \\
\hline $3 \min$ & Correção em pares. & $\begin{array}{l}\text { - Comparar com o colega; } \\
\text { - Passar o áudio para corrigir. }\end{array}$ \\
\hline $15 \mathrm{~min}$ & $\begin{array}{l}\text { Continuação da } \\
\text { atividade adicional II. }\end{array}$ & $\begin{array}{l}\text { - Comparar e discutir as respostas da } \\
\text { atividade adicional } 2 \text { em grupo; } \\
\text { - Corrigir com a professora. }\end{array}$ \\
\hline $2 \min$ & Perguntas & Espaço para perguntas. \\
\hline $1 \mathrm{~min}$ & & Encerrar a aula com o kiritsu. \\
\hline
\end{tabular}

\begin{tabular}{|c|c|c|c|}
\hline \multicolumn{4}{|c|}{ Desenvolvimento - Aula 11 (Rikai - L14) } \\
\hline Tempo & Atividade & Procedimento & Observações \\
\hline $2 \mathrm{~min}$ & Início da aula. & Realizar o kiritsu com o aluno $\mathrm{n}^{\circ} 11$ da lista. & \\
\hline $2 \min$ & Retomada da seção 2. & $\begin{array}{l}\text { Rever o conteúdo trabalhado na aula } \\
\text { anterior. }\end{array}$ & \\
\hline $2 \min$ & 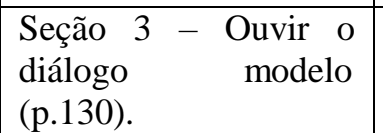 & Passar o áudio. & \\
\hline $4 \min$ & $\begin{array}{l}\text { Identificação das } \\
\text { expressões no diálogo. }\end{array}$ & $\begin{array}{l}\text { - Perguntar sobre o conteúdo do diálogo; } \\
\text { - Identificar as expressões; } \\
\text { - Passar o áudio novamente. }\end{array}$ & \\
\hline $5 \min$ & $\begin{array}{l}\text { Compreensão do } \\
\text { conteúdo linguístico. }\end{array}$ & $\begin{array}{l}\text { - Discutir em grupo (máx. } 4 \text { alunos) o } \\
\text { conteúdo gramatical em destaque e elaborar } \\
\text { uma explicação; } \\
\text { - Exposição do que os grupos entenderam. }\end{array}$ & \\
\hline $3 \min$ & $\begin{array}{l}\text { Exercício } \quad \text { de } \\
\text { gramática. }\end{array}$ & $\begin{array}{l}\text { - Apresentar e explicar o que está sendo } \\
\text { pedido nos exercícios de gramática } 2 ; \\
\text { - Fazer o exercício de gramática } 2 .\end{array}$ & \\
\hline $3 \min$ & Correção em pares. & $\begin{array}{l}\text { - Comparar com o colega; } \\
\text { - Passar o áudio para corrigir. }\end{array}$ & \\
\hline $5 \mathrm{~min}$ & $\begin{array}{l}\text { Compreensão ro do } \\
\text { conteúdo linguístico } \\
\text { (p.131). }\end{array}$ & $\begin{array}{l}\text { - Discutir em grupo (máx. } 4 \text { alunos) o } \\
\text { conteúdo gramatical em destaque e elaborar } \\
\text { uma explicação; } \\
\text { - Exposição do que os grupos entenderam. }\end{array}$ & \\
\hline $3 \min$ & $\begin{array}{l}\text { Exercício } \quad \text { de } \\
\text { gramática. }\end{array}$ & $\begin{array}{l}\text { - Apresentar e explicar o que está sendo } \\
\text { pedido nos exercícios de gramática } 3 \text { e } 4 \text {; } \\
\text { - Fazer os exercícios de gramática } 3 \text { e } 4 \text {. }\end{array}$ & \\
\hline $3 \min$ & Correção em pares. & $\begin{array}{l}\text { - Comparar com o colega; } \\
\text { - Passar o áudio para corrigir. }\end{array}$ & \\
\hline $15 \mathrm{~min}$ & $\begin{array}{l}\text { Atividade adicional } \\
\text { III. }\end{array}$ & $\begin{array}{l}\text { - Apresentar e explicar o que está sendo } \\
\text { pedido na atividade adicional III; } \\
\text { - Fazer a atividade adicional III em dupla. }\end{array}$ & \\
\hline $2 \min$ & Perguntas & Espaço para perguntas. & \\
\hline $1 \min$ & & Encerrar a aula com o kiritsu. & \\
\hline
\end{tabular}




\begin{tabular}{|c|c|c|c|}
\hline Tempo & Atividade & Procedimento & Observações \\
\hline $2 \mathrm{~min}$ & Início da aula. & Realizar o kiritsu com o aluno $\mathrm{n}^{\circ} 12$ da lista. & \\
\hline $2 \min$ & Retomada da seção 3. & $\begin{array}{l}\text { Rever o conteúdo trabalhado na aula } \\
\text { anterior. }\end{array}$ & \\
\hline $10 \mathrm{~min}$ & $\begin{array}{l}\text { Seção } 4 \text { - Exercício de } \\
\text { compreensão de de } \\
\text { leitura (p.132). }\end{array}$ & $\begin{array}{l}\text { - Apresentar e explicar o que está sendo } \\
\text { pedido no exercício de compreensão de } \\
\text { leitura; } \\
\text { - Fazer o exercício de compreensão de } \\
\text { leitura. }\end{array}$ & \\
\hline $4 \min$ & Correção em pares. & $\begin{array}{l}\text { - Comparar com o colega; } \\
\text { - Passar o áudio do texto lido; } \\
\text { - Corrigir com a professora. }\end{array}$ & \\
\hline $14 \mathrm{~min}$ & $\begin{array}{l}\text { Continuação } \mathrm{da} \\
\text { atividade adicional III. }\end{array}$ & $\begin{array}{l}\text { - Comparar e discutir as respostas da } \\
\text { atividade adicional III em turma. }\end{array}$ & \\
\hline $15 \mathrm{~min}$ & Caderno lexical. & $\begin{array}{l}\text { Registrar as unidades lexicais aprendidas na } \\
\text { L14. Comparar com o colega após concluir. }\end{array}$ & \\
\hline $2 \min$ & Perguntas & Espaço para perguntas. & \\
\hline $1 \mathrm{~min}$ & & com kiritsu. & \\
\hline
\end{tabular}




\section{APÊNDICE D - Exercício I}

$$
\begin{array}{r}
\text { ことばの 練習 }-ト ヒ ゚ ッ ク 7 \\
\text { なまえ }: \ldots \ldots
\end{array}
$$

\section{練習 1}

Leia o diálogo abaixo e complete os espaços com as palavras que julgar adequada.

ホセさん：あのう、すみません ...

さとうさん：はい。

ホセさん：ここから くうこうまで どうやって いきますか。

さとうさん：くうこうは がいいですよ。

$$
\text { _ _ - _ _ - ですから。 }
$$

ホセさん：わかりました。ありがとうございました。

Hose-san: Anou, sumimasen...

Satou-san: Hai.

Hose-san: Koko kara kuukou made douyatte ikimasuka.

Satou-san: Kuukou wa ga ii desu yo. desu kara.

Hose-san: Wakarimashita. Arigatou gozaimashita. 


\section{APÊNDICE E - Exercício II}

\section{ことばの 練習 — トピック 7 \\ なまえ：}

練習 2

Forme os pares de palavras.

\begin{tabular}{|c|c|c|c|}
\hline 1.ベんり & a.のりば & 1.Benri & a. noriba \\
\hline 2.えきで & b.ですから & 2.Eki de & b.desu kara \\
\hline 3.タクシー & c.おります。 & 3.Takushii & c. orimasu \\
\hline 4.みなみ & d. てい & 4.Minami & d. tei \\
\hline 5.ちかてつに & e.のります & 5.Chikatetsu ni & e.norimasu \\
\hline 6.バス & f. ぐち & 6.Basu & f. guchi \\
\hline
\end{tabular}




\section{APÊNDICE F - Exercício III}

$$
\begin{aligned}
& \text { ことばの 練習 — トピック } 7 \\
& \text { なまえ： }
\end{aligned}
$$

\section{練習 3}

Marque a palavra do grupo que não combina com a palavra em destaque.

ゆうめいな まち・ひと・テレビ・ところ・レストラン

ひくい やま·おと・ビル・ひと・き

ベんりな ホテル・サービス・ところ・ひと

まちの・ひろい·すくない・きれいな・にぎやかな くうこう

がっこうの・くにの・せかいの・みちの・まちの ちず

Yumeina machi $\cdot$ hito $\cdot$ terebi $\cdot$ tokoro $\cdot$ resutoran

Hikui yama $\cdot$ oto $\cdot$ biru $\cdot$ hito $\cdot$ ki

Benrina hoteru $\cdot$ saabisu $\cdot$ tokoro $\cdot$ hito

machino $\cdot$ hiroi $\cdot$ sukunai $\cdot$ kireina $\cdot$ nigiyakana

gakkouno $\cdot$ kunino $\cdot$ sekaino $\cdot$ michino $\cdot$ machino

\section{kuukou}

chizu 
APÊNDICE G - Atividade I

\section{活動 I - トピック 7}

Jogo de cartas

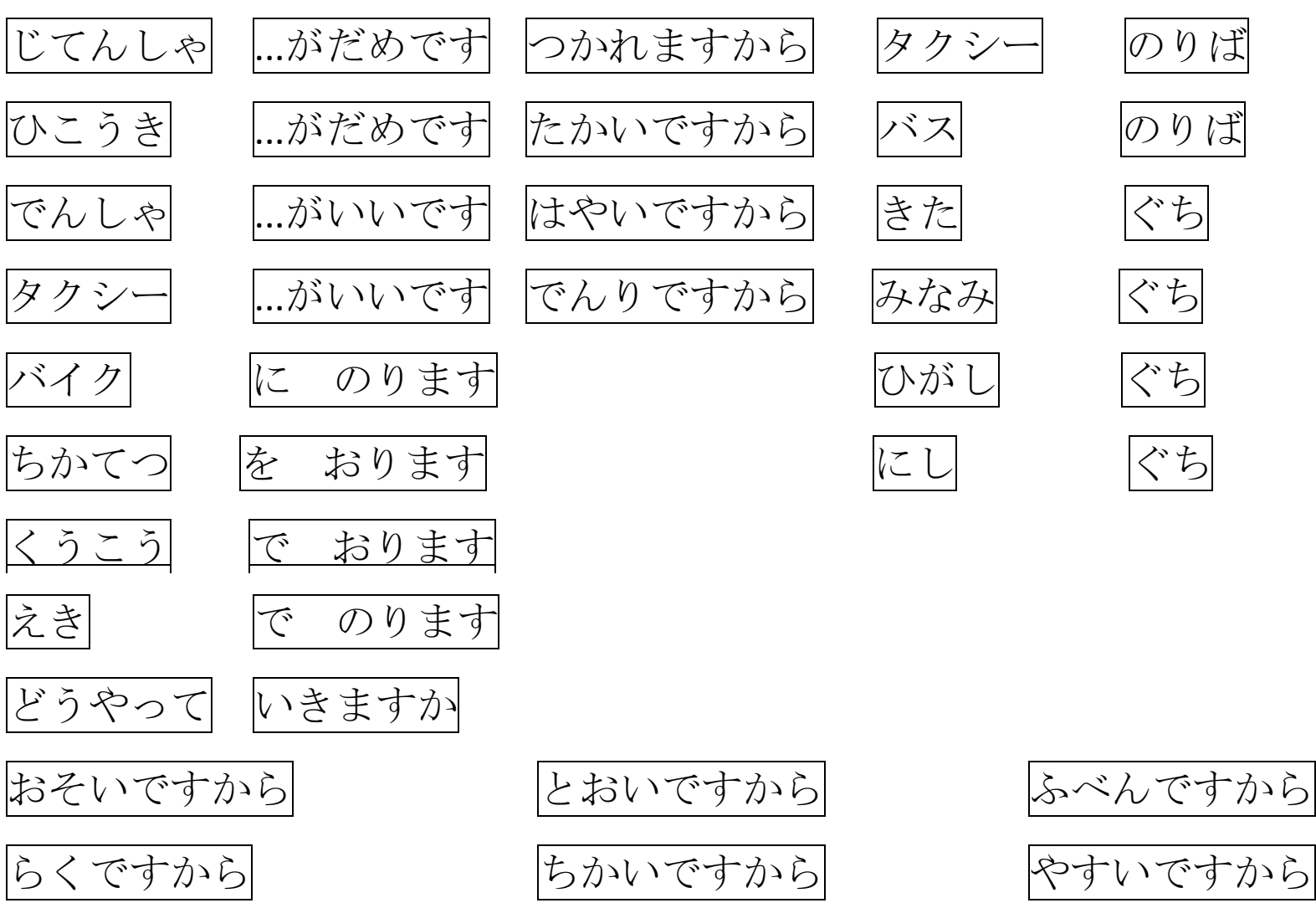

ベんりですから

Forma de jogar

- Cortar em cartões;

- Formar grupos de 4 alunos;

- Distribuir 13 cartas para cada aluno;

- Formar colocações;

- Ganha quem usar todas as cartas ou quem ficar com menos cartas na mão. 
APÊNDICE H - Atividade II

\section{活動 I I ー トピック 7}

なまえ：

Leia o texto e marque de azul as palavras que se combinam (duas a três palavras) e as expressões de amarelo (frases inteiras que são frequentemente usadas da mesma forma ou com pouca variação).

レストランで

チョウ：埼玉はまぼんな町ですか。

きむら：にぎやかな町です。

さいたま なに

チョウ：埼玉に何がありますか。

きむら：古い神社があります。有名な博 物 館もあります。

チョウ:そうですか。いいですね。神社はここから遠いですか。

ちか

きむら：いいえ、近いです。

チョウ：神 社までじうやって行きますか

きむら：そうですね。ちかてつがいいですよ。いちばんべんりですから。 チョウ：そうですか。

きむら：上野駅でちかてつに乗ります。三根口駅で降ります。そして、 バスに乗ります。

チョウ：わかりました。行ってみます。どうもありがとうございました。

Linha pontilhada $=$ expressões institucionalizadas fixas e semifixas.

Linha sólida $=$ colocações fixas e livres. 


\section{APÊNDICE I - Atividade III}

\section{活動 I I I - トピック 7}

なまえ：

Leia as expressões abaixo:

1.どちらまでですか。

2.いくらですか。

3. どうやっていきますか。

4.ここでいいです。

5. カードでいいですか。

6.じてんしゃが いいです。 ちかいですから。

7.まっすぐいってください。

8.もしもし、いま、どこですか。

9.まちのちずを もらえますか。

10.ゆうめいな おてらは どこですか。
1. Dochira made desuka.

2. Ikura desuka.

3. Douyatte ikimasuka.

4. Kokode iidesuka.

5. Kaadode iidesuka.

6. Jitenshaga iidesu. Chikai desukara.

7. Massugu ittekudasai.

8. Moshimoshi, ima dokodesuka.

9. Machino chizu o moraemasuka.

10. Yumeina oterawa dokodesuka.

Agora discuta com o seu colega a resposta das seguintes perguntas sobre as expressões acima:

1) Em quais situações essas expressões podem ocorrer?

2) Quem poderia dizer essas expressões?

3) O que poderia ter acontecido antes dessas expressões serem faladas?

4) Que tipo de resposta ou reação a cada expressão pode ocorrer? 
197

APÊNDICE J - Caderno Lexical - Tópico 7 - L13 Vamos organizar as palavras!

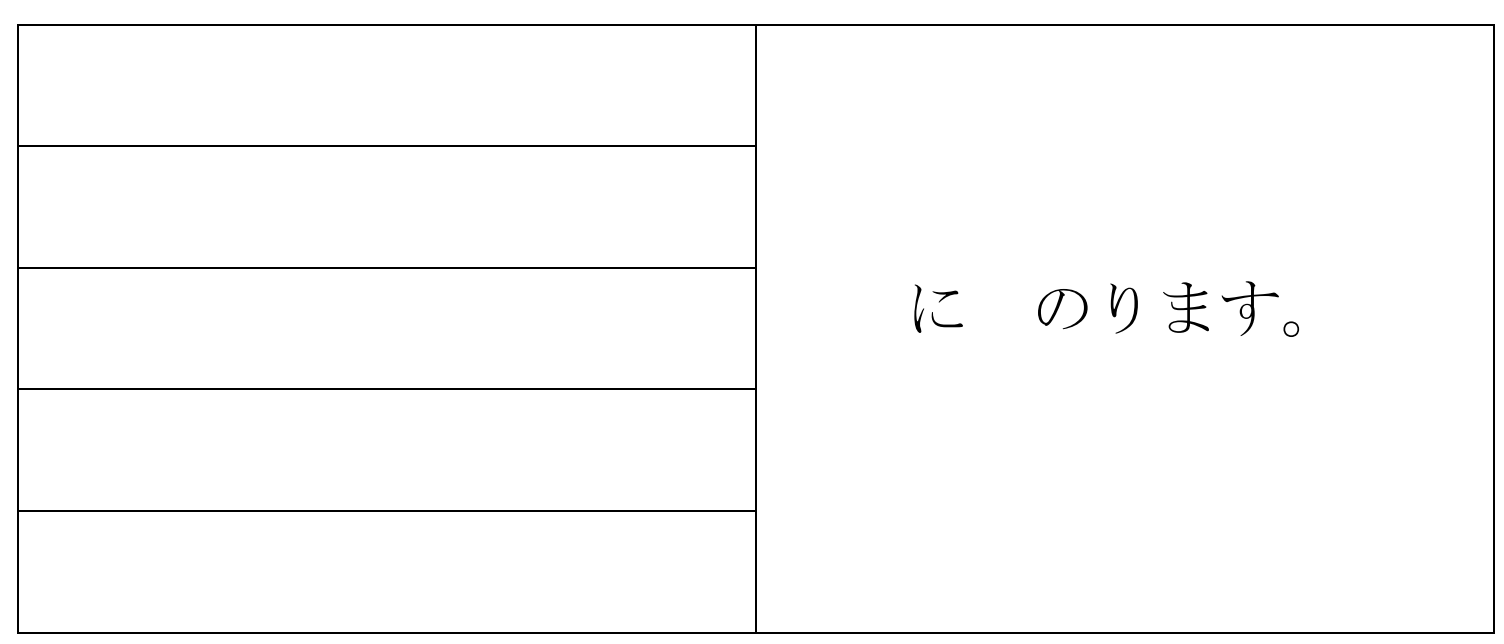

\begin{tabular}{|l|l|}
\hline \multicolumn{1}{|l|}{} & \\
\cline { 1 - 1 } & \\
\cline { 1 - 1 } & \\
\hline & \\
\hline
\end{tabular}

ちかてつ に

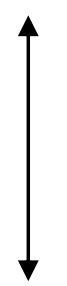

バスをを 
198

\begin{tabular}{|l|l|}
\hline \multicolumn{1}{|l|}{} & \\
\cline { 1 - 1 } & \\
\hline & \\
\hline & \\
\hline
\end{tabular}

\begin{tabular}{|l|l|}
\hline \multicolumn{1}{|l|}{} & \multicolumn{2}{|c|}{ で おります。 } \\
\cline { 1 - 1 } & \\
\hline
\end{tabular}

\begin{tabular}{|l|l|}
\hline \multirow{2}{*}{ に つきます。 } & \\
\hline & \\
\hline & \\
\hline
\end{tabular}

いきます。 
199
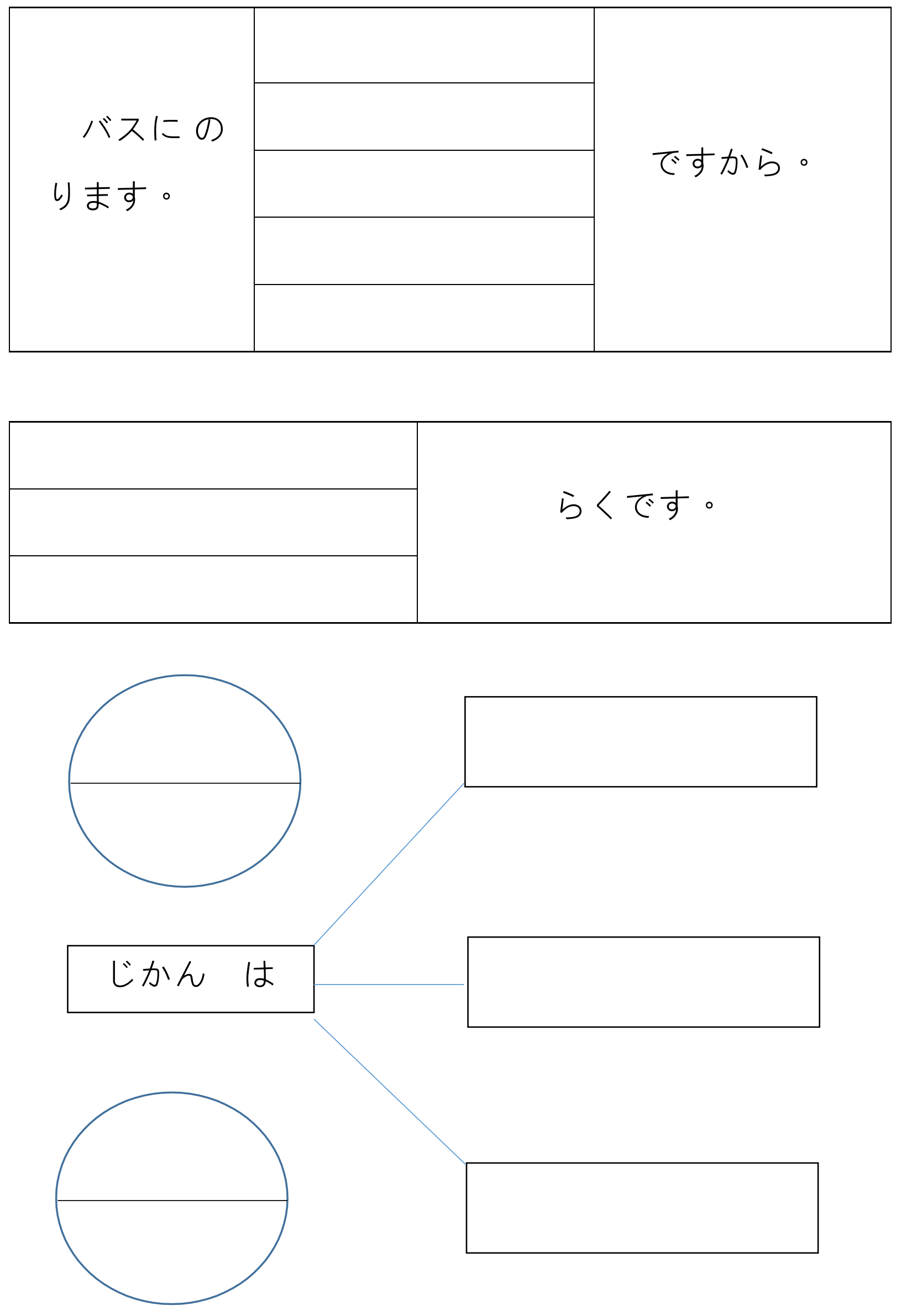


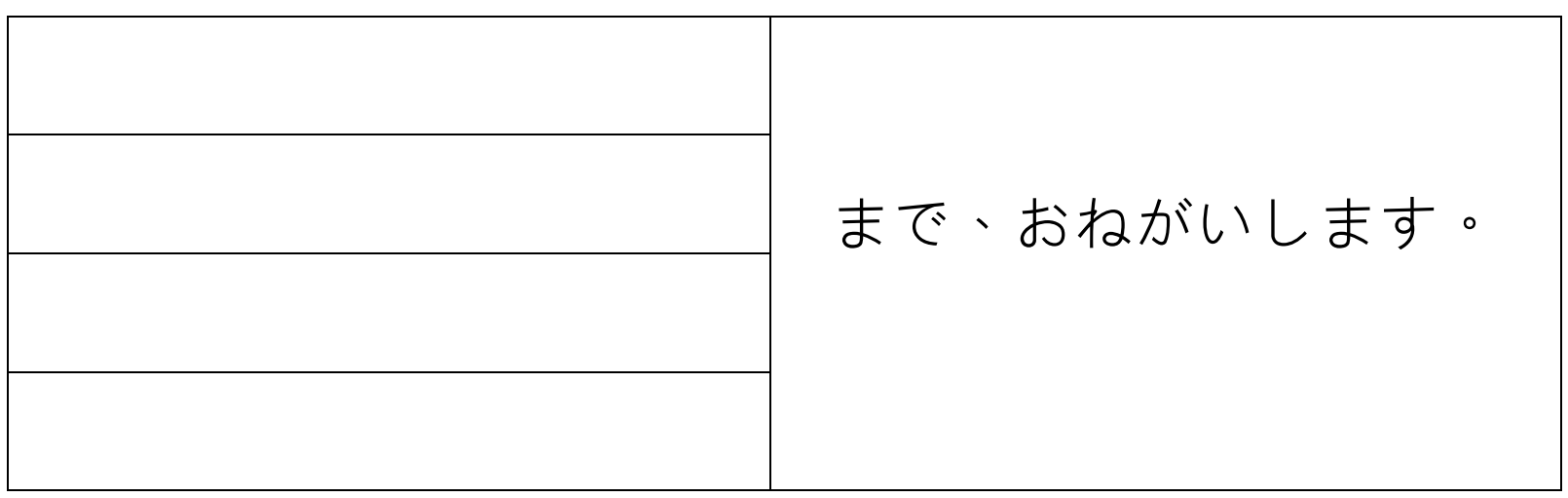

Expressões - No táxi
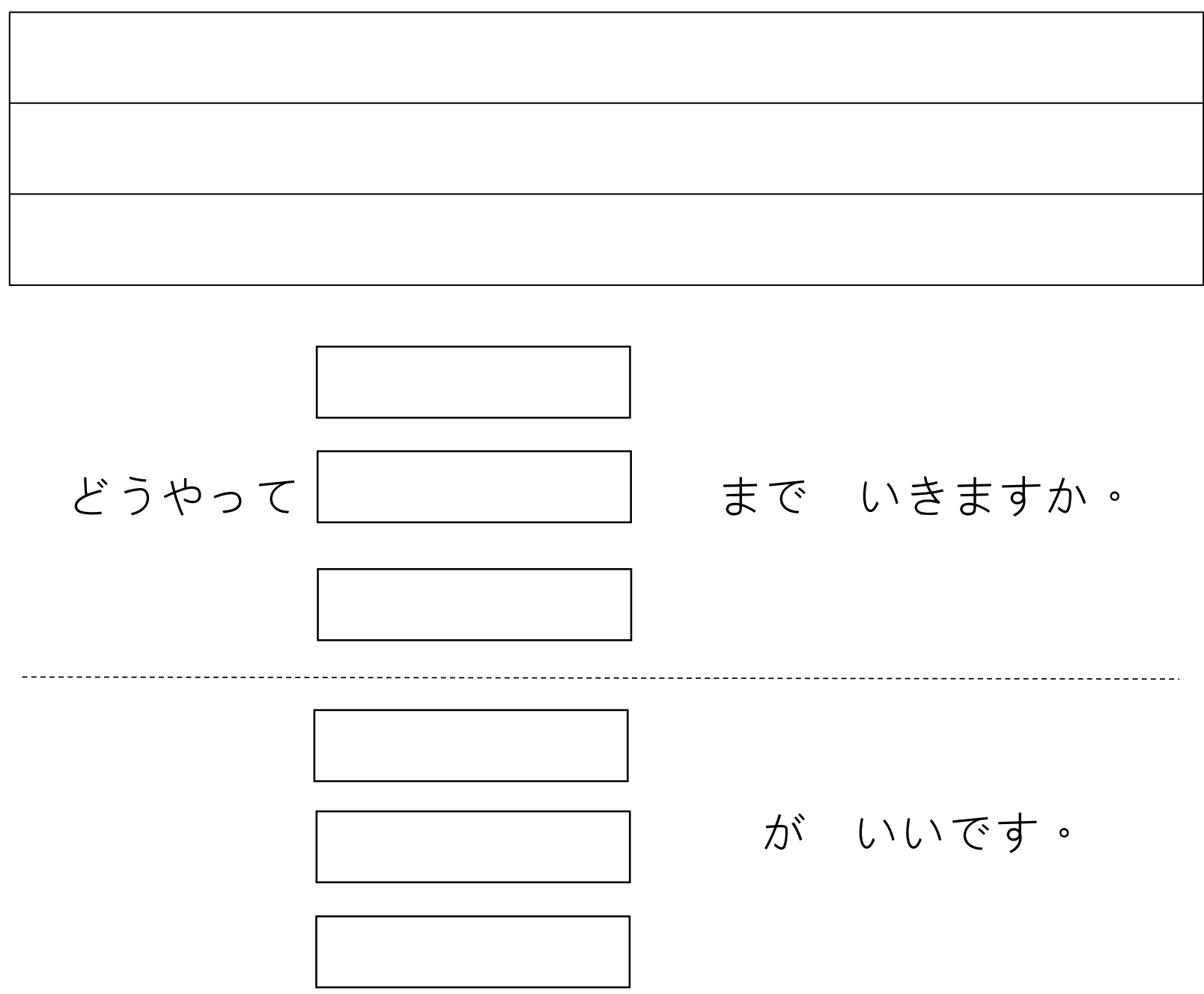

がいいです。

でいいです。
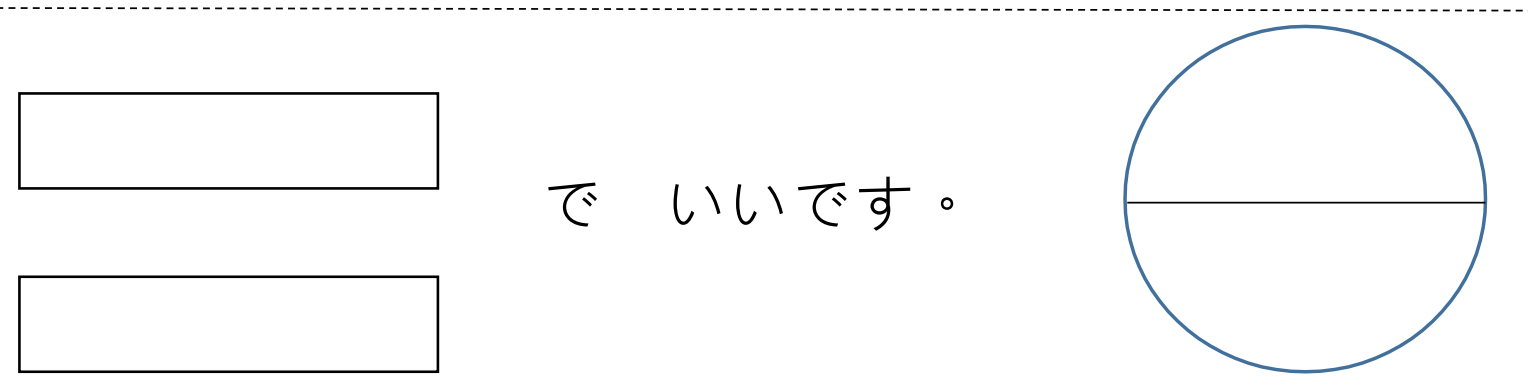

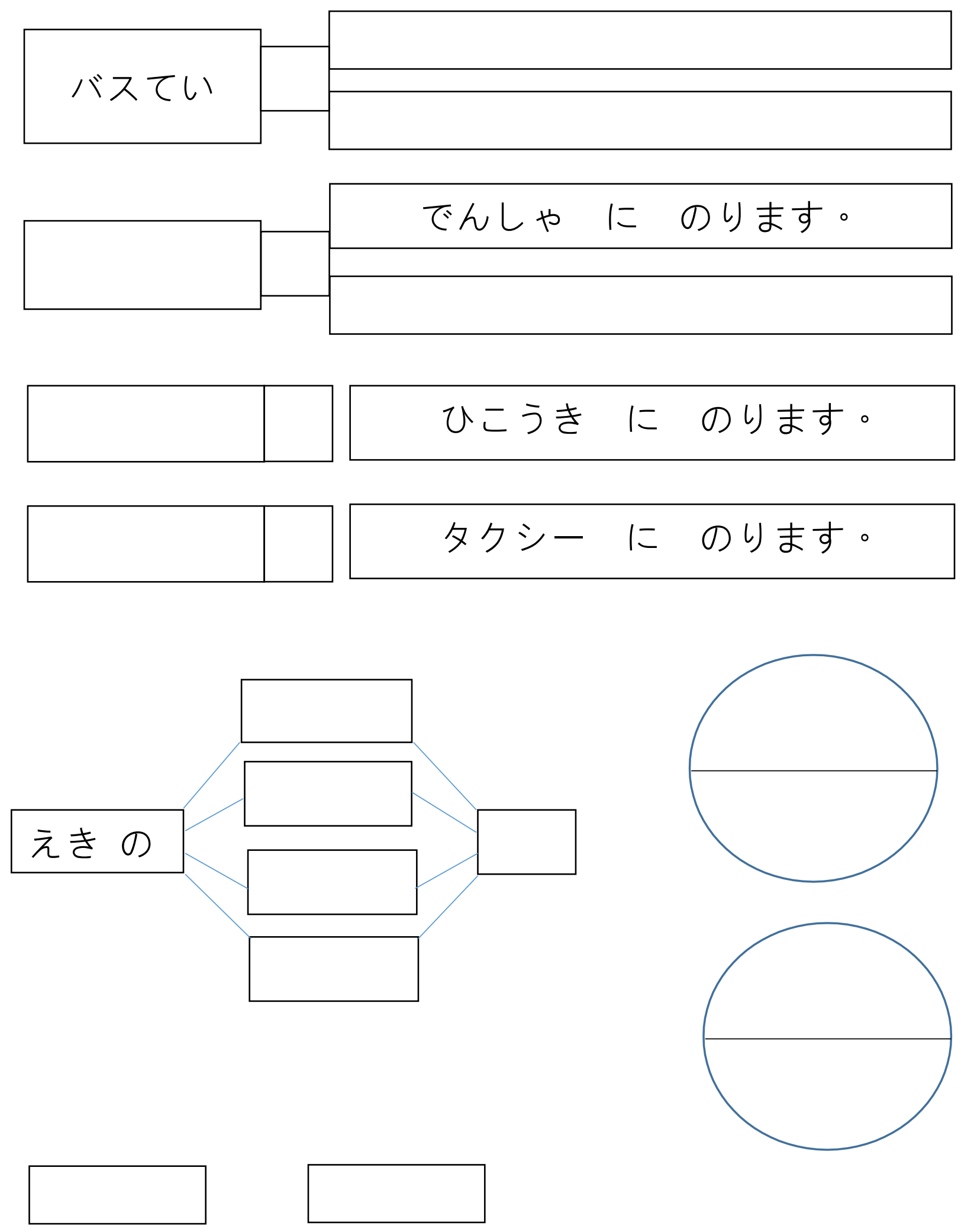

から
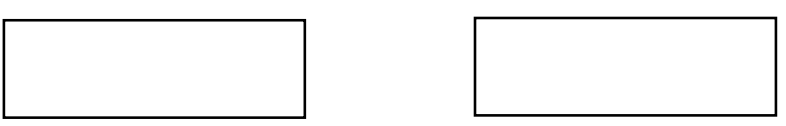
Anotações

Para mim, as palavras mais importantes ou úteis são: 
203

APÊNDICE K - Caderno Lexical - Tópico 7 - L14 Vamos organizar as palavras!

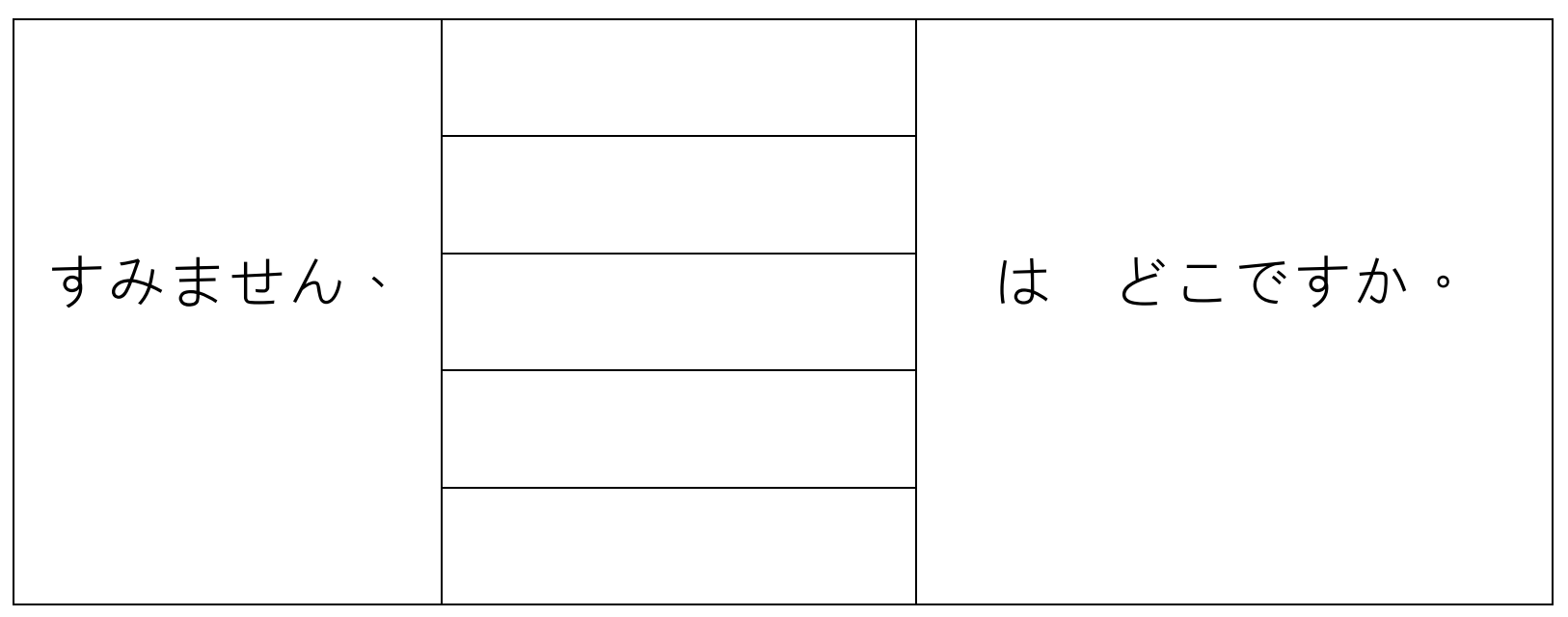

\begin{tabular}{|l|l|}
\hline & \\
\cline { 1 - 1 } & \multirow{2}{*}{ は ここです。 } \\
\hline \multicolumn{1}{|l|}{} \\
\cline { 1 - 1 } & \\
\hline
\end{tabular}

\begin{tabular}{|l|l|}
\hline \multirow{4}{*}{ ゆうめいな } & \\
\cline { 2 - 2 } & \\
\cline { 2 - 2 } & \\
\hline
\end{tabular}

\begin{tabular}{|l|l|}
\hline \multirow{2}{*}{ にぎやかな } & \\
\cline { 2 - 2 } & \\
\cline { 2 - 2 } & \\
\hline
\end{tabular}



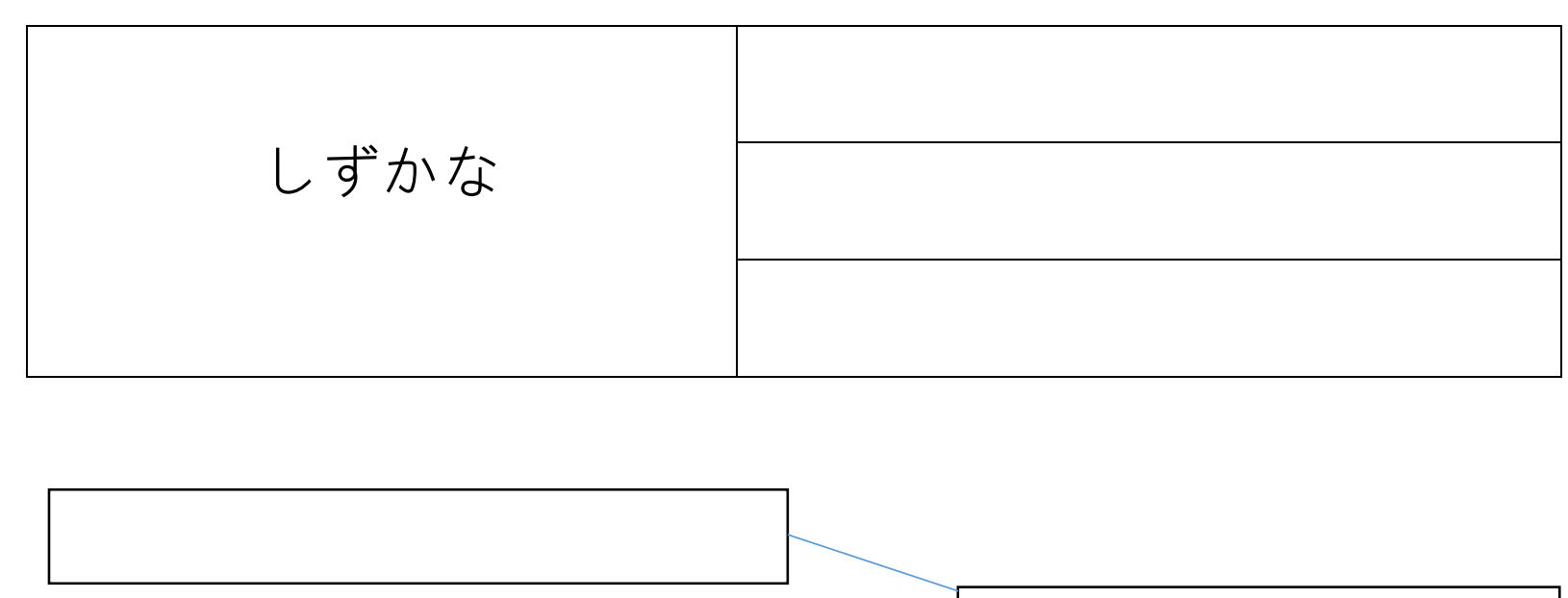

ホテルです。

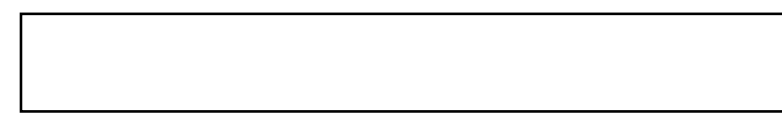

ビルです。

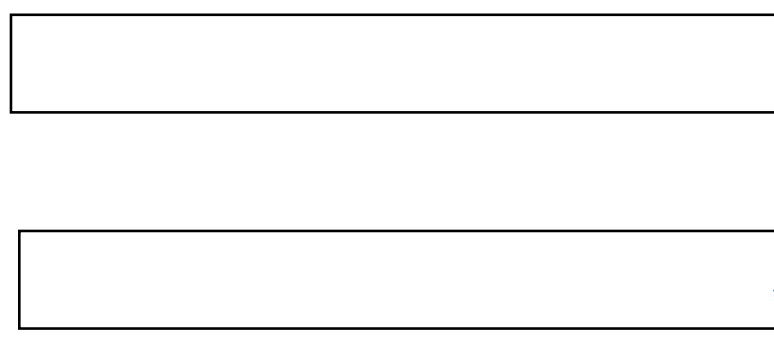

みせです。

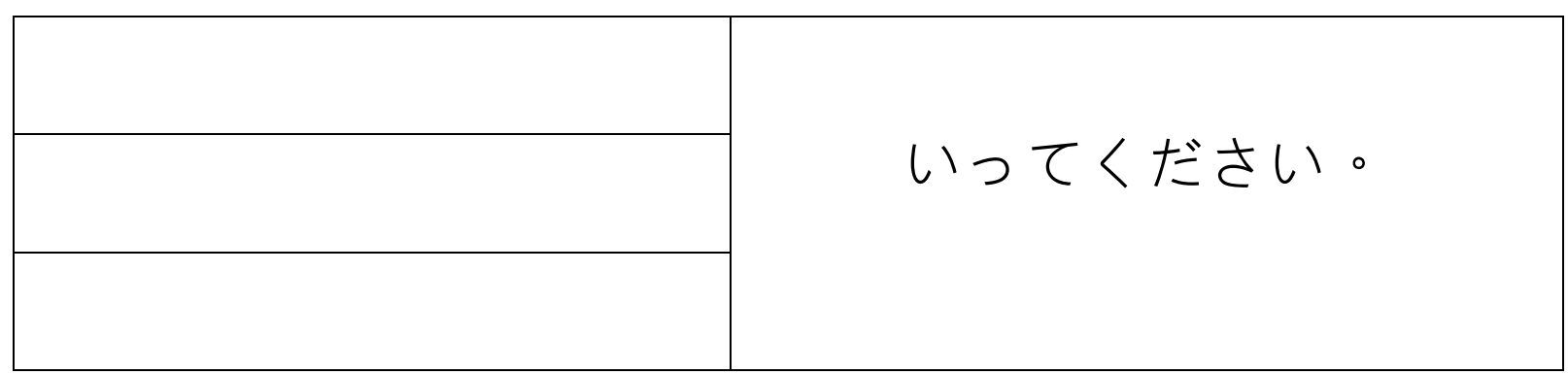



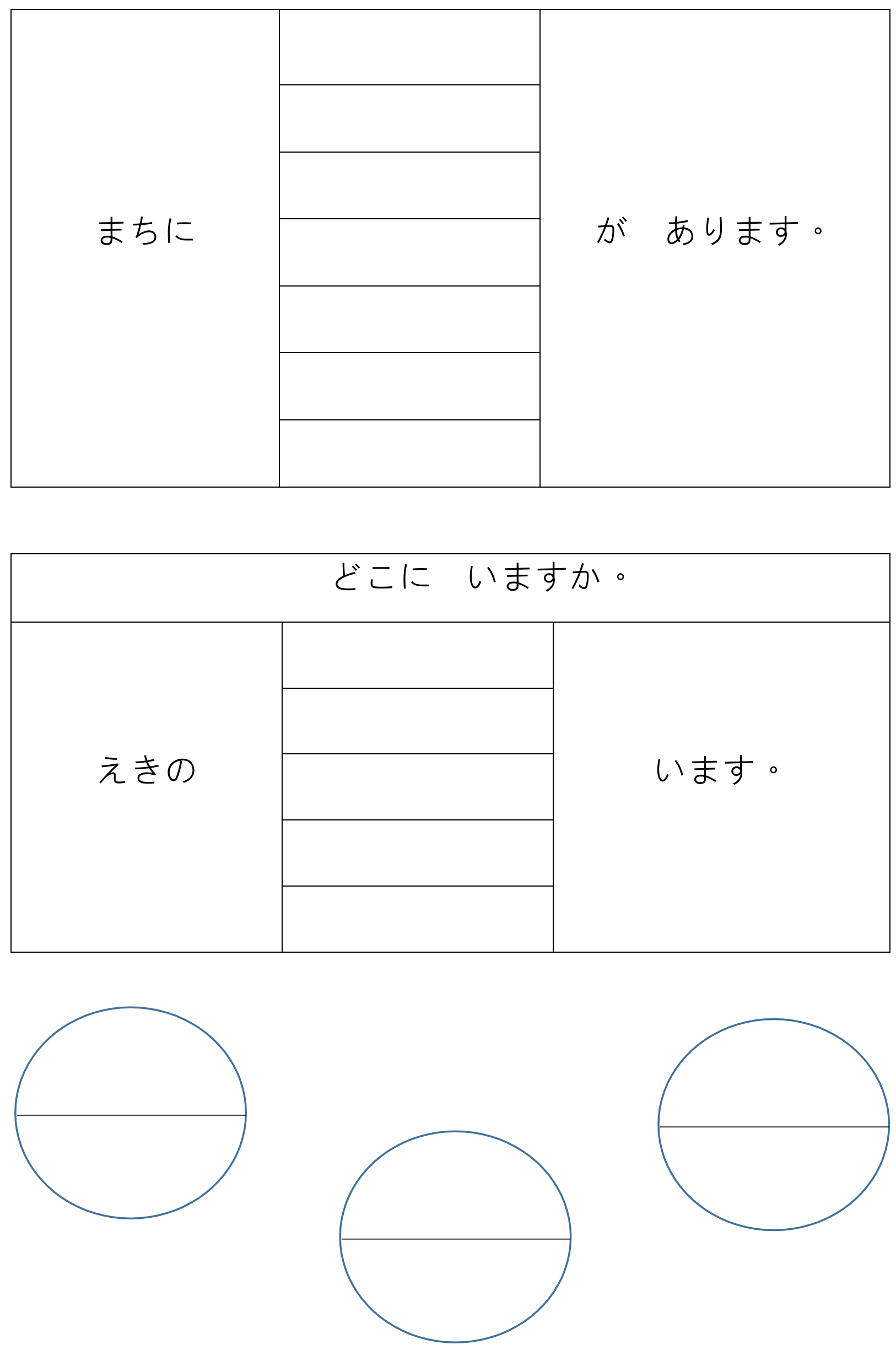
Anotações

Para mim, as palavras mais importantes ou úteis são... 
APÊNDICE L - Escores Simplificados Grupo Experimental

\begin{tabular}{lcccccccccc}
\hline & \multicolumn{1}{c}{ Norimasu } & \multicolumn{2}{c}{ Chizu } & \multicolumn{1}{c}{ Massugu } & \multicolumn{2}{c}{ Benri } & \multicolumn{2}{c}{ Kukô } \\
& PTI & PTP & PTI & PTP & PTI & PTP & PTI & PTP & PTI & PTP \\
\hline P1 & 2 & 1 & 1 & 1 & 1 & 1 & 1 & 1 & 2 & 2 \\
P2 & 2 & 2 & 2 & 2 & 1 & 1 & 1 & 1 & 1 & 2 \\
P3 & 2 & 1 & 2 & 2 & 2 & 2 & 1 & 2 & 2 & 2 \\
P4 & 2 & 2 & 2 & 2 & 2 & 2 & 2 & 2 & 2 & 2 \\
P5 & 2 & 2 & 2 & 2 & 1 & 1 & 2 & 2 & 2 & 2 \\
P6 & 2 & 1 & 2 & 2 & 1 & 1 & 1 & 1 & 2 & 2 \\
P7 & 2 & 2 & 1 & 1 & 1 & 1 & 1 & 1 & 2 & 2 \\
P8 & 2 & 2 & 2 & 2 & 2 & 1 & 2 & 1 & 2 & 1 \\
P9 & 1 & 2 & 1 & 1 & 2 & 1 & 2 & 2 & 2 & 2 \\
P10 & 1 & 2 & 2 & 2 & 1 & 1 & 1 & 1 & 2 & 2 \\
P11 & 2 & 2 & 2 & 2 & 2 & 2 & 1 & 1 & 2 & 2 \\
P12 & 2 & 1 & 2 & 2 & 1 & 1 & 1 & 1 & 2 & 2 \\
\hline
\end{tabular}

\begin{tabular}{lcccccccccc}
\hline & \multicolumn{2}{c}{ Orimasu } & \multicolumn{2}{c}{ Dôytte } & \multicolumn{2}{c}{ Tôi } & \multicolumn{2}{c}{ Chikai } & \multicolumn{2}{c}{ Yumei } \\
& PTI & PTP & PTI & PTP & PTI & PTP & PTI & PTP & PTI & PTP \\
\hline P1 & 1 & 1 & 1 & 1 & 1 & 1 & 1 & 1 & 1 & 1 \\
P2 & 2 & 2 & 1 & 1 & 1 & 1 & 1 & 1 & 2 & 2 \\
P3 & 2 & 1 & 1 & 1 & 1 & 1 & 2 & 2 & 2 & 2 \\
P4 & 2 & 2 & 2 & 2 & 1 & 1 & 2 & 2 & 2 & 2 \\
P5 & 2 & 2 & 1 & 1 & 1 & 1 & 1 & 1 & 2 & 2 \\
P6 & 2 & 1 & 1 & 1 & 1 & 1 & 1 & 1 & 2 & 1 \\
P7 & 2 & 2 & 1 & 1 & 1 & 1 & 1 & 1 & 2 & 2 \\
P8 & 2 & 2 & 2 & 2 & 1 & 1 & 1 & 1 & 2 & 1 \\
P9 & 1 & 1 & 1 & 1 & 1 & 1 & 1 & 1 & 1 & 1 \\
P10 & 1 & 1 & 1 & 1 & 1 & 1 & 1 & 1 & 1 & 1 \\
P11 & 2 & 1 & 1 & 1 & 1 & 1 & 1 & 1 & 2 & 2 \\
P12 & 1 & 1 & 1 & 1 & 1 & 1 & 1 & 1 & 2 & 1 \\
\hline
\end{tabular}

$\mathrm{P}=$ Participante

PTI= Pós-teste imedaito

PTP= Pós-teste postergado 
APÊNDICE M - Escores Simplificados Grupo Controle

\begin{tabular}{lcccccccccc}
\hline & \multicolumn{1}{c}{ Norimasu } & \multicolumn{2}{c}{ Chizu } & \multicolumn{2}{c}{ Massugu } & \multicolumn{2}{c}{ Benri } & \multicolumn{2}{c}{ Kukô } \\
& PTI & PTP & PTI & PTP & PTI & PTP & PTI & PTP & PTI & PTP \\
\hline P1 & 2 & 2 & 2 & 2 & 2 & 2 & 2 & 1 & 2 & 4 \\
P2 & 5 & 5 & 5 & 5 & 1 & 1 & 5 & 5 & 4 & 5 \\
P3 & 2 & 2 & 2 & 2 & 1 & 2 & 2 & 2 & 3 & 3 \\
P4 & 2 & 2 & 2 & 2 & 2 & 2 & 1 & 1 & 2 & 2 \\
P5 & 2 & 2 & 2 & 2 & 1 & 1 & 2 & 2 & 2 & 2 \\
P6 & 2 & 2 & 2 & 2 & 3 & 3 & 2 & 2 & 2 & 3 \\
P7 & 2 & 2 & 1 & 2 & 2 & 1 & 2 & 2 & 2 & 1 \\
P8 & 2 & 4 & 4 & 4 & 2 & 2 & 3 & 2 & 2 & 3 \\
P9 & 2 & 2 & 2 & 2 & 2 & 3 & 2 & 2 & 2 & 1 \\
P10 & 2 & 3 & 2 & 2 & 2 & 1 & 4 & 3 & 3 & 3 \\
P11 & 2 & 2 & 2 & 2 & 1 & 1 & 2 & 2 & 2 & 2 \\
\hline
\end{tabular}

\begin{tabular}{lcccccccccc}
\hline & \multicolumn{1}{c}{ Orimasu } & \multicolumn{2}{c}{ Dobyatte } & \multicolumn{2}{c}{ Toi } & \multicolumn{2}{c}{ Chikai } & \multicolumn{2}{c}{ Yumei } \\
& PTI & PTP & PTI & PTP & PTI & PTP & PTI & PTP & PTI & PTP \\
\hline P1 & 2 & 2 & 1 & 2 & 2 & 2 & 1 & 2 & 2 & 2 \\
P2 & 5 & 5 & 2 & 5 & 2 & 2 & 2 & 5 & 5 & 5 \\
P3 & 2 & 2 & 5 & 5 & 3 & 3 & 1 & 2 & 2 & 2 \\
P4 & 1 & 2 & 2 & 2 & 2 & 2 & 2 & 2 & 4 & 2 \\
P5 & 2 & 2 & 2 & 2 & 1 & 1 & 1 & 1 & 2 & 2 \\
P6 & 2 & 2 & 1 & 2 & 2 & 2 & 1 & 2 & 2 & 2 \\
P7 & 2 & 2 & 1 & 1 & 2 & 1 & 2 & 1 & 2 & 2 \\
P8 & 2 & 4 & 2 & 2 & 2 & 2 & 2 & 2 & 3 & 3 \\
P9 & 2 & 2 & 2 & 2 & 1 & 2 & 2 & 2 & 1 & 2 \\
P10 & 2 & 2 & 2 & 2 & 2 & 1 & 2 & 2 & 2 & 2 \\
P11 & 2 & 1 & 2 & 2 & 1 & 2 & 2 & 1 & 1 & 1 \\
\hline
\end{tabular}

$\mathrm{P}=$ Participante

PTI= Pós-teste imediato

PTP= Pós-teste postergado 
APÊNDICE N - Escores Reais Grupo Experimental

\begin{tabular}{lllllllllll}
\hline & \multicolumn{3}{c}{ Norimasu } & \multicolumn{2}{c}{ Chizu } & \multicolumn{2}{c}{ Massugu } & \multicolumn{2}{c}{ Benri } & \multicolumn{2}{c}{ Kakk } \\
& PTI & PTP & PTI & PTP & PTI & PTP & PTI & PTP & PTI & PTP \\
\hline P1 & 5 & 2 & 2 & 2 & 2 & 1 & 2 & 2 & 4 & 5 \\
P2 & 5 & 5 & 5 & 4 & 2 & 2 & 2 & 2 & 2 & 3 \\
P3 & 5 & 2 & 5 & 5 & 5 & 5 & 2 & 4 & 5 & 4 \\
P4 & 4 & 5 & 5 & 5 & 5 & 5 & 5 & 5 & 4 & 5 \\
P5 & 5 & 5 & 5 & 5 & 2 & 2 & 4 & 4 & 4 & 5 \\
P6 & 4 & 2 & 5 & 5 & 2 & 2 & 2 & 2 & 5 & 4 \\
P7 & 4 & 3 & 1 & 2 & 2 & 2 & 2 & 2 & 3 & 4 \\
P8 & 5 & 5 & 5 & 5 & 4 & 2 & 5 & 2 & 5 & 2 \\
P9 & 2 & 4 & 2 & 2 & 4 & 1 & 5 & 5 & 5 & 5 \\
P10 & 2 & 3 & 4 & 3 & 1 & 1 & 2 & 2 & 4 & 3 \\
P11 & 5 & 5 & 5 & 3 & 5 & 3 & 2 & 2 & 5 & 3 \\
P12 & 4 & 2 & 5 & 3 & 2 & 1 & 2 & 2 & 4 & 3 \\
\hline
\end{tabular}

\begin{tabular}{lllllllllll}
\hline & \multicolumn{2}{c}{ Orimasu } & \multicolumn{2}{c}{ Doyatte } & \multicolumn{2}{c}{ Toi } & \multicolumn{2}{c}{ Chikai } & \multicolumn{2}{c}{ Yumei } \\
& PTI & PTP & PTI & PTP & PTI & PTP & PTI & PTP & PTI & PTP \\
\hline P1 & 2 & 2 & 2 & 2 & 1 & 2 & 1 & 1 & 2 & 1 \\
P2 & 4 & 4 & 2 & 2 & 2 & 2 & 2 & 2 & 5 & 5 \\
P3 & 5 & 2 & 2 & 2 & 2 & 1 & 5 & 5 & 5 & 5 \\
P4 & 5 & 5 & 5 & 5 & 2 & 2 & 5 & 5 & 4 & 5 \\
P5 & 4 & 5 & 2 & 2 & 2 & 2 & 2 & 2 & 5 & 5 \\
P6 & 3 & 2 & 2 & 2 & 2 & 2 & 2 & 2 & 5 & 2 \\
P7 & 4 & 4 & 2 & 2 & 2 & 2 & 2 & 2 & 4 & 3 \\
P8 & 4 & 4 & 5 & 5 & 2 & 2 & 2 & 2 & 5 & 2 \\
P9 & 2 & 2 & 2 & 2 & 2 & 2 & 2 & 2 & 2 & 2 \\
P10 & 2 & 2 & 2 & 2 & 2 & 2 & 2 & 1 & 2 & 2 \\
P11 & 4 & 2 & 2 & 2 & 1 & 2 & 1 & 2 & 4 & 5 \\
P12 & 2 & 2 & 2 & 2 & 2 & 1 & 2 & 2 & 4 & 2 \\
\hline
\end{tabular}

$\mathrm{P}=$ Participante

PTI= Pós-teste imediato

PTP= Pós-teste postergado 


\section{APÊNDICE O - Escores Reais Grupo Controle}

\begin{tabular}{lllllllllll}
\hline & \multicolumn{3}{l}{ Norimasu } & \multicolumn{2}{l}{ Chizu } & \multicolumn{2}{l}{ Massugu } & \multicolumn{2}{l}{ Benri } & \multicolumn{2}{l}{ Kuko } \\
& PTI & PTP & PTI & PTP & PTI & PTP & PTI & PTP & PTI & PTP \\
\hline P1 & 2 & 2 & 2 & 2 & 2 & 2 & 2 & 1 & 2 & 4 \\
P2 & 5 & 5 & 5 & 5 & 1 & 1 & 5 & 5 & 4 & 5 \\
P3 & 2 & 2 & 2 & 2 & 1 & 2 & 2 & 2 & 3 & 3 \\
P4 & 2 & 2 & 2 & 2 & 2 & 2 & 1 & 1 & 2 & 2 \\
P5 & 2 & 2 & 2 & 2 & 1 & 1 & 2 & 2 & 2 & 2 \\
P6 & 2 & 2 & 2 & 2 & 3 & 3 & 2 & 2 & 2 & 3 \\
P7 & 2 & 2 & 1 & 2 & 2 & 1 & 2 & 2 & 2 & 1 \\
P8 & 2 & 4 & 4 & 4 & 2 & 2 & 3 & 2 & 2 & 3 \\
P9 & 2 & 2 & 2 & 2 & 2 & 3 & 2 & 2 & 2 & 1 \\
P10 & 2 & 3 & 2 & 2 & 2 & 1 & 4 & 3 & 3 & 3 \\
P11 & 2 & 2 & 2 & 2 & 1 & 1 & 2 & 2 & 2 & 2 \\
\hline
\end{tabular}

\begin{tabular}{lllllllllll}
\hline & \multicolumn{1}{c}{ Orimasu } & \multicolumn{1}{l}{ Dôyatte } & Tói & \multicolumn{2}{c}{ Chikai } & \multicolumn{2}{l}{ Yumei } \\
& PTI & PTP & PTI & PTP & PTI & PTP & PTI & PTP & PTI & PTP \\
\hline P1 & 2 & 2 & 1 & 2 & 2 & 2 & 1 & 2 & 2 & 2 \\
P2 & 5 & 5 & 2 & 5 & 2 & 2 & 2 & 5 & 5 & 5 \\
P3 & 2 & 2 & 5 & 5 & 3 & 3 & 1 & 2 & 2 & 2 \\
P4 & 1 & 2 & 2 & 2 & 2 & 2 & 2 & 2 & 4 & 2 \\
P5 & 2 & 2 & 2 & 2 & 1 & 1 & 1 & 1 & 2 & 2 \\
P6 & 2 & 2 & 1 & 2 & 2 & 2 & 1 & 2 & 2 & 2 \\
P7 & 2 & 2 & 1 & 1 & 2 & 1 & 2 & 1 & 2 & 2 \\
P8 & 2 & 4 & 2 & 2 & 2 & 2 & 2 & 2 & 3 & 3 \\
P9 & 2 & 2 & 2 & 2 & 1 & 2 & 2 & 2 & 1 & 2 \\
P10 & 2 & 2 & 2 & 2 & 2 & 1 & 2 & 2 & 2 & 2 \\
P11 & 2 & 1 & 2 & 2 & 1 & 2 & 2 & 1 & 1 & 1 \\
\hline
\end{tabular}




\section{APÊNDICE P - Respostas escritas do PTI do GE}

\section{QUADRO 12 - Respostas escritas da categoria V do pós-teste imediato do grupo experimental}

\begin{tabular}{|c|c|c|c|}
\hline $\mathbf{P}$ & Palavra & Resposta dada & Escore \\
\hline \multirow[t]{2}{*}{ P1 } & Norimasu & でんしやに のります。/ Densha ni norimasu. & 5 \\
\hline & $K \hat{u} k \hat{o}$ & $\begin{array}{lll}\text { たくし } \\
\text { ikimasu. }\end{array}$ & 4 \\
\hline \multirow[t]{6}{*}{$\mathrm{P} 2$} & Norimasu & でんしや に のります。/ Densha ni norimasu. & 5 \\
\hline & Chizu & せかい の ちず / Sekai no chizu. & 5 \\
\hline & $K \hat{u} k \hat{o}$ & $\begin{array}{l}\text { くうこう に いきます。/ Kuukou ni ikimasu. } \\
\text { *Não ofereceu tradução. }\end{array}$ & 2 \\
\hline & Orimasu & でんしゃにおります。/ Densha ni orimasu. & 4 \\
\hline & Chikai & ちかい こうえん / Chikai kouen. & 2 \\
\hline & Yûmei & ゆうめいな みせ / Yuumeina mise. & 5 \\
\hline \multirow[t]{10}{*}{ P3 } & Norimasu & バス に のります。/ Basu ni norimasu. & 5 \\
\hline & Chizu & ちずを もらえますか。/ Chizu o moraemasuka. & 5 \\
\hline & Massugu & まっすぐ いってください。/Massugu itte kudasai. & 5 \\
\hline & Benri & $\begin{array}{l}\text { ベんり です から。/ Benri desu kara. } \\
\text { *Erro de tradução. }\end{array}$ & 2 \\
\hline & $K \hat{u} k \hat{o}$ & くうこう が いい & 5 \\
\hline & Orimasu & バス を おります。/Basu o orimasu. & 5 \\
\hline & Dôyatte & どうやって いきますか。/ Douyatte ikimasuka. & 5 \\
\hline & Tôi & $\begin{array}{l}\text { とおい です から。/ Tooi desu kara. } \\
\text { *Erro de tradução. }\end{array}$ & 2 \\
\hline & Chikai & ちかいですから。/ Chikai desu kara. & 5 \\
\hline & Yûmei & ゆうめいな おてら / Yuumeina otera. & 5 \\
\hline \multirow[t]{9}{*}{$\mathrm{P} 4$} & Norimasu & バス で のります。/ Basu de norimasu. & 4 \\
\hline & Chizu & $\begin{array}{l}\begin{array}{l}\text { まち の ちず } \\
\text { chizu o moraemasuka. }\end{array} \\
\end{array}$ & 5 \\
\hline & Massugu & まっすぐいきます。/Massugu ikimasu. & 5 \\
\hline & Benri & ベんり です から。/ Benri desu kara. & 5 \\
\hline & $K \hat{u} k \hat{o}$ & $\begin{array}{l}\text { ゆうめいな くうこう } \\
\text { kuukou doko desuka. }\end{array}$ & 4 \\
\hline & Orimasu & ちかてつ を おります。/ Chikatetsu o orimasu. & 5 \\
\hline & Dôyate & どうやって いきますか。/ Douyatte ikimasuka. & 5 \\
\hline & Chikai & ちかい です から。/ Chikai desu kara. & 5 \\
\hline & Yûmei & $\begin{array}{l}\text { ゆうめいな おてら } \\
\text { otera doko desuka. }\end{array}$ & 4 \\
\hline \multirow[t]{4}{*}{ P5 } & Norimasu & バス に のります。/Basu ni norimasu. & 5 \\
\hline & Chizu & $\begin{array}{l}\begin{array}{l}\text { まち の ちず を もらいます。/ Machi no } \\
\text { chizu o moraimasu. }\end{array} \\
\end{array}$ & 5 \\
\hline & Benri & バスのりば ベんり です。/ Basunoriba benri desu. & 4 \\
\hline & $K \hat{u} k \hat{o}$ & わたし わ くうこう なか です。/Watashi wa & 4 \\
\hline
\end{tabular}




\begin{tabular}{|c|c|c|c|}
\hline & & \multicolumn{2}{|l|}{ kuukou naka desu. } \\
\hline & Orimasu & えきをおります。/Eki o orimasu. & 4 \\
\hline & Dôyatte & $\begin{array}{l}\text { どうやって いきますか。/ Douyatte ikimasuka. } \\
\text { *Tradução errada. }\end{array}$ & 2 \\
\hline & Tôi & $\begin{array}{l}\text { わたし わ } 12 \text { :0 0 れます です。とおいで } \\
\text { すれ。/Watashi wa 12:00 remasu desu. Tooi desu re. } \\
\text { *Erro de tradução. }\end{array}$ & 2 \\
\hline & Yûmei & ゆうめいな いえ です。/Yuumeina ie desu. & 5 \\
\hline \multirow[t]{6}{*}{ P6 } & Norimasu & バス を のります。/ Basu o norimasu. & 4 \\
\hline & Chizu & $\begin{array}{l}\text { くに の } \\
\text { moraimasu. }\end{array}$ & 5 \\
\hline & Benri & $\begin{array}{l}\text { バス の ベんり です。/ Basu no benri desu. } \\
\text { *Erro de tradução. }\end{array}$ & 2 \\
\hline & Kûkô & くうこう から いきます。/ Kuukou kara ikimasu. & 5 \\
\hline & Orimasu & $\begin{array}{l}\text { ちいさい みせ を おります。Chiisai mise o } \\
\text { orimasu. } \\
\text { *Erro de tradução. }\end{array}$ & 3 \\
\hline & Yûmei & ゆうめいな レストラン / Yuumeina resutoran. & 5 \\
\hline \multirow[t]{4}{*}{ P7 } & Norimasu & 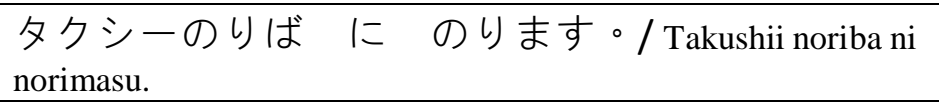 & 4 \\
\hline & Orimasu & でんしやにおります。/ Densha ni orimasu. & 4 \\
\hline & Tôi & $\begin{array}{l}\text { とおい を ぎよ/ Tooi giyo. } \\
\text { *Erro de tradução. }\end{array}$ & 2 \\
\hline & Yûmei & ゆうめい おてら / Yuumei otera. & 4 \\
\hline \multirow[t]{8}{*}{ P8 } & Norimasu & バス に のります。/ Basu ni norimasu. & 5 \\
\hline & Chizu & $\begin{array}{l}\begin{array}{l}\text { まち } \\
\text { mimasu. }\end{array} \\
\text { hず を みます。/Machi no chizu o }\end{array}$ & 5 \\
\hline & Massugu & まっすぐ を いきます。/Massugu o ikimasu. & 4 \\
\hline & Benri & $\begin{array}{l}\text { バス が いい です。べんり です から。 } \\
\text { Basu ga ii desu. Benri desu kara. }\end{array}$ & 5 \\
\hline & $K \hat{u} k \hat{o}$ & くうこう に いきます。/Kuukou ni ikimasu. & 5 \\
\hline & Orimasu & バス に おります。/Basu ni orimasu. & 4 \\
\hline & Dôyatte & どうやって いきますか。/ Douyatte ikimasuka. & 5 \\
\hline & Ŷ̂mei & ゆうめいな ホテル / Yuumeina hoteru. & 5 \\
\hline \multirow[t]{5}{*}{ P9 } & Chizu & $\begin{array}{l}\text { ちず わ すき です。/ Chizu wa suki desu. } \\
\text { *Erro de tradução. }\end{array}$ & 2 \\
\hline & Massugu & えき の まっすぐ です。/ Eki no massugu desu. & 4 \\
\hline & Benri & バス わ ベんり です。/ Basu wa benri desu. & 5 \\
\hline & $K \hat{u} k \hat{o}$ & $\begin{array}{l}\text { にぎやあかな } \\
\text { kuukou desu. }\end{array}$ & 5 \\
\hline & Tôi & $\begin{array}{l}\text { にぎやかな とおい / Nigiyakana tooi. } \\
\text { *Erro de tradução. }\end{array}$ & 2 \\
\hline \multirow[t]{3}{*}{ P10 } & Chizu & まち に ちず です。/ Machi ni chizu desu. & 4 \\
\hline & Kûkô & くうこう いきます。/ Kuukou ikimasu. & 4 \\
\hline & Yûmei & $\begin{array}{l}\text { わたし は ゆめい です。/ Watashi ha yumei desu. } \\
\text { *Erro de tradução. }\end{array}$ & 2 \\
\hline P11 & Norimasu & たくしー に のります。/ Takushii ni norimasu. & 5 \\
\hline
\end{tabular}




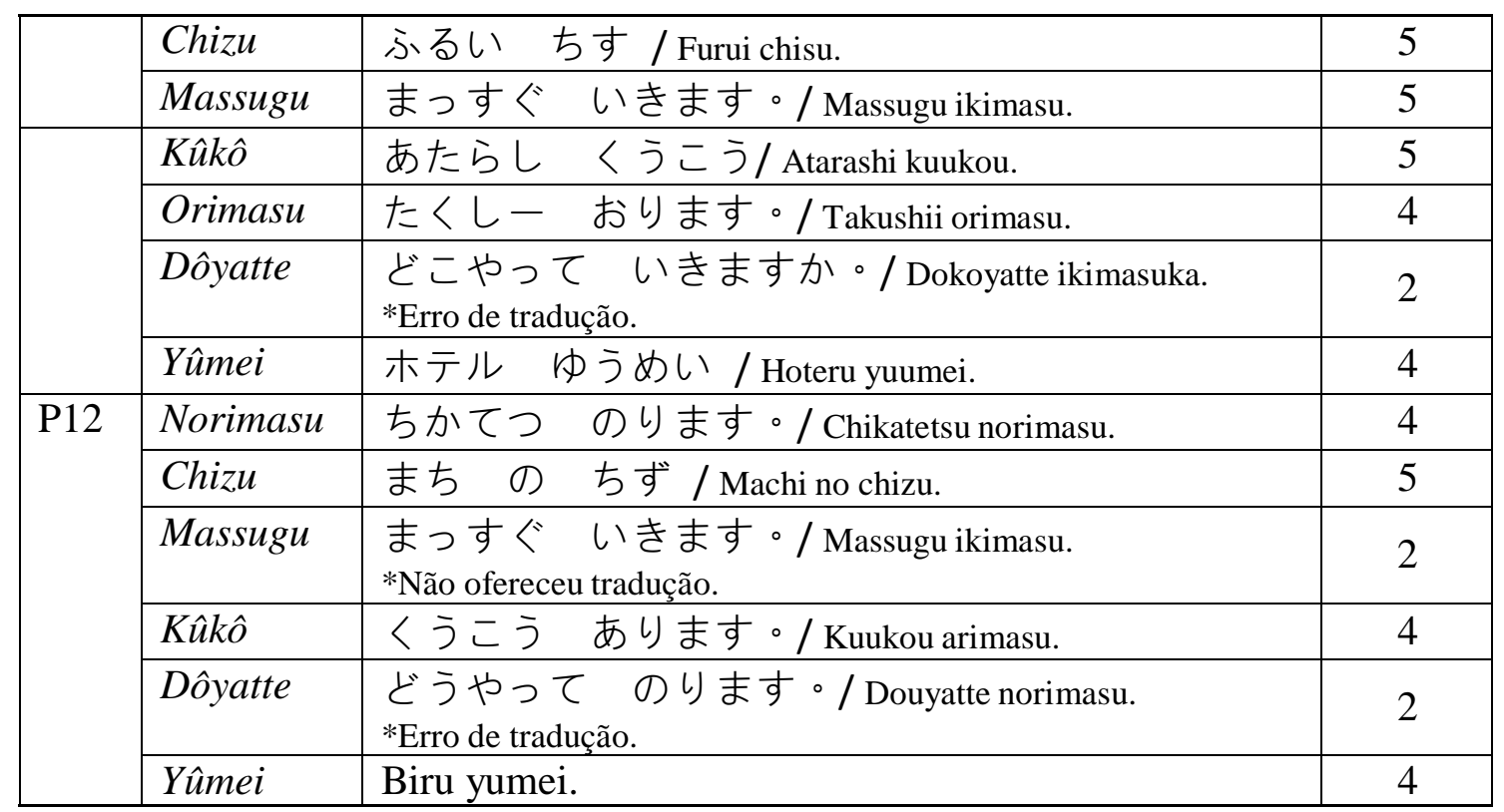




\section{APÊNDICE Q - Respostas escritas do PTP do GE}

\section{QUADRO 13 - Respostas escritas da categoria V do pós-teste postergado do grupo experimental}

\begin{tabular}{|c|c|c|c|}
\hline $\mathbf{P}$ & Palavra & Resposta dada & Escore \\
\hline \multirow[t]{2}{*}{ P1 } & Norimasu & $\begin{array}{l}\text { おじゃー て } \\
\text { *Erro de tradução. }\end{array}$ & 2 \\
\hline & $K \hat{u} k \hat{o}$ & くうこうに いきます。/ Kuukou ni ikimasu. & 5 \\
\hline \multirow[t]{5}{*}{$\mathrm{P} 2$} & Norimasu & バス に のります。/ Basu ni norimasu. & 5 \\
\hline & Chizu & せかい の ちす / Sekai no chisu. & 4 \\
\hline & $K \hat{u} k \hat{o}$ & くうこう にいぎます。/ Kuukou niigimasu. & 3 \\
\hline & Orimasu & バス の おります。/ Basu no orimasu. & 4 \\
\hline & Yûmei & ゆうめいな こうえん / Yuumeina kouen & 5 \\
\hline \multirow[t]{9}{*}{ P3 } & Norimasu & $\begin{array}{l}\text { くうこう を } \\
\text { *Erro de tradução. }\end{array}$ & 2 \\
\hline & Chizu & まち の ちず/ Machi no chizu. & 5 \\
\hline & Massugu & まっすぐ いきます。/Massugu ikimasu. & 5 \\
\hline & Benri & ベんり まち です。/Benri desu kara. & 4 \\
\hline & $K \hat{u} k \hat{o}$ & くうこう を のります。/ Kuukou o norimasu. & 4 \\
\hline & Orimasu & $\begin{array}{l}\text { くうこう を } \\
\text { *Erro de tradução. }\end{array}$ & 2 \\
\hline & Dôyatte & $\begin{array}{l}\text { よ゙うやって いきますか。/ Douyatte ikimasuka. } \\
\text { *Erro de tradução. }\end{array}$ & 2 \\
\hline & Chikai & ちかいです。/ Chikai desu. & 5 \\
\hline & Yûmei & ゆうめいな おてら / Yuumeina otera. & 5 \\
\hline \multirow[t]{9}{*}{ P4 } & Norimasu & バス に のります。/ Basu ni norimasu. & 5 \\
\hline & Chizu & ちず を もらいますか。/ chizu o moraimasuka. & 5 \\
\hline & Massugu & まっすぐ いってください。/Massugu itte kudasai. & 5 \\
\hline & Benri & ベんり です から。/ Benri desu kara. & 5 \\
\hline & $K \hat{u} k \hat{o}$ & $\begin{array}{l}\text { くうこうで おります。/Yuumeina kuukou doko } \\
\text { desuka. }\end{array}$ & 5 \\
\hline & Orimasu & でんしゃ を おります。/ Densha o orimasu. & 5 \\
\hline & Dôyate & どうやって いきますか。/ Douyatte ikimasuka. & 5 \\
\hline & Chikai & ちかい です から。/ Chikai desu kara. & 5 \\
\hline & Yûmei & ゆうめいな おてら/ Yuumeina otera doko desuka. & 5 \\
\hline \multirow[t]{6}{*}{ P5 } & Norimasu & バス に のります。/Basu ni norimasu. & 5 \\
\hline & Chizu & まち の ちずです。/ Machi no chizu desu. & 5 \\
\hline & Benri & バス ベんり です。/ Basu benri desu. & 4 \\
\hline & Kûkô & くうこう でおります。/ Kuukou de orimasu. & 5 \\
\hline & Orimasu & バスのりばでおります。/ Basunoriba de orimasu. & 5 \\
\hline & Yûmei & $\begin{array}{l}\text { ゆうめいな おすしや } \\
\text { desu. }\end{array}$ & 5 \\
\hline P6 & Norimasu & $\begin{array}{l}\text { バス に のります。/ Basu ni norimasu. } \\
\text { *Erro de tradução. }\end{array}$ & 2 \\
\hline
\end{tabular}




\begin{tabular}{|c|c|c|c|}
\hline & Chizu & $\begin{array}{l}\text { くに の ちず を もらいます。/ Kuni no chizu o } \\
\text { moraimasu. }\end{array}$ & 5 \\
\hline & Benri & $\begin{array}{l}\text { ベんりに のります。/Benri ni norimasu. } \\
\text { *Erro de tradução. }\end{array}$ & 2 \\
\hline & Kûkô & くうこう に のります。/ Kuukou ni norimasu. & 4 \\
\hline & Yûmei & $\begin{array}{l}\text { ゆうめい おてら/ Yuumei otera. } \\
\text { *Erro de tradução. }\end{array}$ & 2 \\
\hline \multirow[t]{2}{*}{ P7 } & Benri & $\begin{array}{l}\text { ちず を ベんり / Chizu o benri. } \\
\text { *Erro de tradução. }\end{array}$ & 2 \\
\hline & Orimasu & くうこう を おります。/ Kuukou wo orimasu. & 4 \\
\hline \multirow[t]{4}{*}{ P8 } & Norimasu & バス に のります。/ Basu ni norimasu. & 5 \\
\hline & Chizu & まち の ちず / Machi no chizu. & 5 \\
\hline & Orimasu & バス に おります。/Basu ni orimasu. & 4 \\
\hline & Dôyatte & どうやって いきますか。/ Douyatte ikimasuka. & 5 \\
\hline \multirow[t]{3}{*}{ P9 } & Norimasu & ベス を のります。/ Besu o norimasu. & 4 \\
\hline & Benri & $\begin{array}{l}\text { でんしゃ わ ベんり です。/Densha wa benri } \\
\text { desu. }\end{array}$ & 5 \\
\hline & $K \hat{u} k \hat{o}$ & $\begin{array}{l}\text { くうこう わ } \\
\text { nigiyakana desu. }\end{array}$ & 5 \\
\hline \multirow[t]{2}{*}{ P11 } & Norimasu & しかてす に のります。/ Shikatesu ni norimasu. & 5 \\
\hline & Yûmei & ゆうめいな ホテル / Yuumeina hoteru. & 5 \\
\hline
\end{tabular}




\section{APÊNDICE R - Respostas escritas do PTI do GC}

QUADRO 14 - Respostas escritas da categoria V do pós-teste imediato do grupo controle

\begin{tabular}{|c|c|c|c|}
\hline $\mathbf{P}$ & Palavra & Resposta dada & Escore \\
\hline P1 & $K \hat{u} k \hat{o}$ & $\begin{array}{l}\text { くうこう いきますか。/ Kuukou ikimasuka. } \\
\text { *Erro de tradução. }\end{array}$ & 2 \\
\hline \multirow[t]{6}{*}{$\mathrm{P} 2$} & Norimasu & タクシー に のります。/ Takushii ni norimasu. & 5 \\
\hline & Chizu & ちず を みます。 / Chizu o mimasu. & 5 \\
\hline & Benri & ベんりな バス/Benrina basu. & 5 \\
\hline & $K \hat{u} k \hat{o}$ & $\begin{array}{l}\text { くうこう に ひこうき } \\
\text { Kuukou ni hikouki ni norimasu. }\end{array}$ & 4 \\
\hline & Orimasu & バス を おります。/Basu o orimasu. & 5 \\
\hline & Yûmei & ゆうめいな おてら / Yuumeina otera. & 5 \\
\hline \multirow[t]{2}{*}{ P3 } & Dôyatte & どうやって いきますか。/ Douyatte ikimasuka. & 5 \\
\hline & Yûmei & $\begin{array}{l}\text { ゆうめい どころ / Yuumeina dokoro. } \\
\text { *Erro de tradução. }\end{array}$ & 2 \\
\hline \multirow[t]{2}{*}{ P4 } & Dôyatte & $\begin{array}{l}\text { よ゙うやって いきます。/ Douyatte ikimasu. } \\
\text { *Erro de tradução. }\end{array}$ & 2 \\
\hline & Yûmei & びる ゆうめい / Biru yuumei. & 4 \\
\hline \multirow[t]{4}{*}{ P8 } & Norimasu & $\begin{array}{l}\text { さくらえき の のります。/ Sakuraeki no norimasu. } \\
\text { *Erro de tradução. }\end{array}$ & 2 \\
\hline & Chizu & ちずのまち / Chizu no machi. & 4 \\
\hline & Orimasu & $\begin{array}{l}\text { バス に おります。/ Basu ni orimasu. } \\
\text { *Erro de tradução. }\end{array}$ & 2 \\
\hline & Yûmei & ゆうめいな とおい / Yuumeina tooi. & 3 \\
\hline P9 & Norimasu & $\begin{array}{l}\text { しかてす に } \text { にります。/ Shikatesu ni norimasu. } \\
\text { *Erro de tradução. }\end{array}$ & 2 \\
\hline P10 & Benri & くうこう / Benri kuukou & 4 \\
\hline
\end{tabular}


APÊNDICE S - Respostas escritas do PTP do GC

\section{QUADRO 15 - Respostas escritas da categoria V do pós-teste postergado do grupo controle}

\begin{tabular}{|c|c|c|c|}
\hline $\mathbf{P}$ & Palavra & Resposta dada & Escore \\
\hline \multirow[t]{2}{*}{$\mathrm{P} 1$} & $K \hat{u} k \hat{o}$ & くうこうに のりますか。/ Kuukou ni norimasuka. & 4 \\
\hline & Tôi & $\begin{array}{l}\text { とおい に にきますか。/ Tooi ni ikimasuka. } \\
\text { *Erro de tradução. }\end{array}$ & 2 \\
\hline \multirow[t]{9}{*}{$\mathrm{P} 2$} & Norimasu & タクシー に のります。/ Takushii ni norimasu. & 5 \\
\hline & Chizu & ちず を みました。 / Chizu o mimashita. & 5 \\
\hline & Benri & ホホテル は ベんり です。/ Hoteru ha benri desu. & 5 \\
\hline & $K \hat{u} k \hat{o}$ & $\begin{array}{l}\text { この くうこう } \\
\text { kuukou ha ookii desu. }\end{array}$ & 5 \\
\hline & Orimasu & ふねね を おります。/ Fune o orimasu. & 5 \\
\hline & Douyatte & どうやって いきますか。/ Douyatte ikimasuka. & 5 \\
\hline & Tôi & $\begin{array}{l}\text { スーパー は } \\
\text { *Erro de tradução. }\end{array}$ & 2 \\
\hline & Chikai & てら は ちかい ですか。/Tera ha chikai desuka. & 5 \\
\hline & Yûmei & ゆうめいな ビル / Yuumeina biru. & 5 \\
\hline \multirow[t]{2}{*}{ P3 } & Dôyatte & どうやって いきますか。/ Douyatte ikimasuka. & 5 \\
\hline & Yûmei & $\begin{array}{l}\text { ゆうめいな どころ / Yuumeina dokoro. } \\
\text { *Erro de tradução. }\end{array}$ & 2 \\
\hline \multirow[t]{2}{*}{$\mathrm{P} 4$} & Chizu & $\begin{array}{l}\text { ぷるい の ちず/ Purui no chizu. } \\
\text { *Erro de tradução. }\end{array}$ & 2 \\
\hline & Yûmei & $\begin{array}{l}\text { ともだち に } \text { ゆうめい/ Tomodachi ni yuumeina } \\
\text { *Erro de tradução. }\end{array}$ & 2 \\
\hline \multirow[t]{6}{*}{ P8 } & Norimasu & えき を のります。/Eki o norimasu. & 4 \\
\hline & Chizu & ちずのまち です。/Chizu no machi. & 4 \\
\hline & Benri & $\begin{array}{l}\text { まち の ベんり です。Machi no benri desu. } \\
\text { *Erro de tradução. }\end{array}$ & 2 \\
\hline & Orimasu & えき の おります。/Eki no orimasu. & 4 \\
\hline & $T \hat{i} i$ & $\begin{array}{l}\text { ゆうめいな とおい / Yuumei na tooi. } \\
\text { *Erro de tradução. }\end{array}$ & 2 \\
\hline & Yûmei & ゆうめいな とおい / Yuumeina tooi & 3 \\
\hline
\end{tabular}

